UNIVERSIDADE DE SÃO PAULO

INSTITUTO DE GEOCIENCIAS

\title{
O PAPEL DO SISTEMA DE ZONAS DE CISALHAMENTO TRANSCORRENTES NA \\ CONFIGURAÇÃO DA PORÇĀO MERIDIONAL DA
} FAIXA RIBEIRA

Ginaldo Ademar da Cruz Campanha

Tese apresentada so Concurso de Livre-Docéncia junto ao Departamento de Mineralogia e Geotectónico do Instituto de Geociências da Universidade de São Paulo, na Área de Conhecimento de Geologia Estrutural/Geotectónica. 


\section{O PAPEL DO SISTEMA DE ZONAS DE CISALHAMENTO TRANSCORRENTES NA CONFIGURAÇÃO DA PORÇÃO MERIDIONAL DA FAIXA RIBEIRA}

\section{INTRODUÇÃO}

1.1 Preâmbulo

1.2 Os cinturões de cisalhamento transcorrentes continentais no contexto da tectônica global 2

1.30 sistema de zonas de cisalhamento da região sudeste do Brasil - Histórico 6

1.4 A configuração geométrica do sistema 10

2. FUNDAMENTAÇÃO TEÓRICA . 14

2.1 Análise tensorial da deformação 15

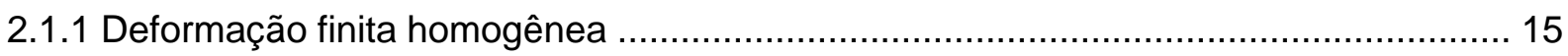

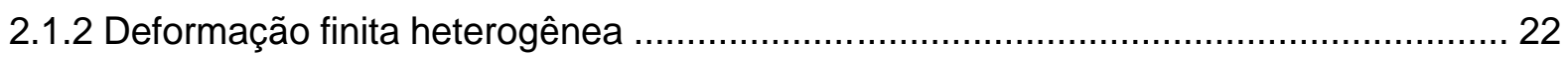

2.2. Modelos cinemáticos e dinâmicos de zonas de cisalhamento ................................... 25

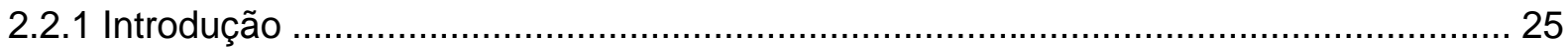

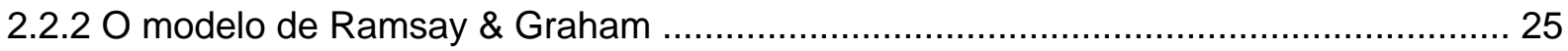

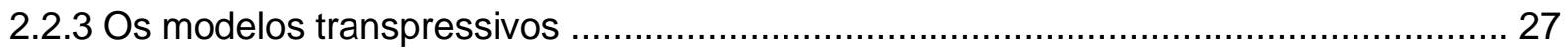

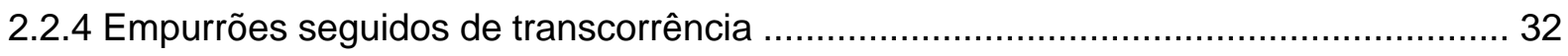

2.2.5 Ainda sobre a questão dos elipsóides oblatos em zonas de cisalhamento ................. 33

2.2.6 Modelagem física e a partição da deformação em zonas de convergência oblíqua ... 33

2.2.7 O comportamento mecânico dos materiais - Em busca de um novo modelo .............. 34

2.2.8 Sobre a questão do ângulo entre conjugados ..................................................... 37

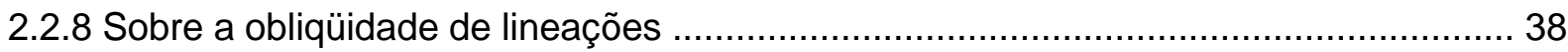

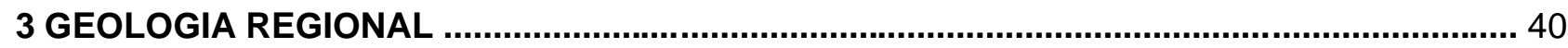

4. ANÁLISE DA DEFORMAÇÃO NO MÉDIO RIBEIRA ...................................................... 50

4.1 Determinações do strain finito $\quad 50$

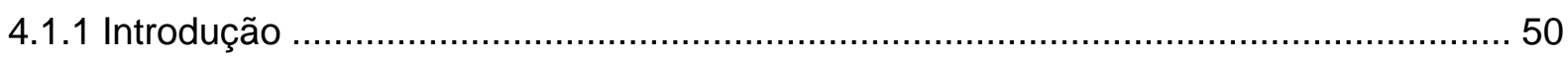

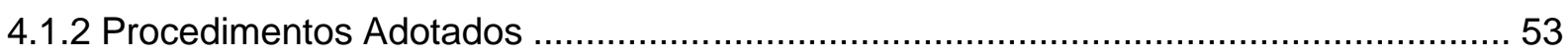

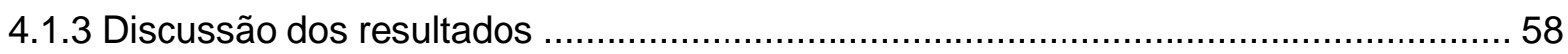

4.1.4 Tensores de deformação recalculados para as orientações geográficas ................... 62

4.2 Variação química e volumétrica de metabasitos afetados pelo Lineamento Ribeira ... 65

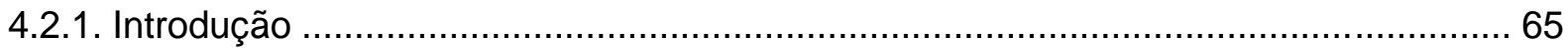

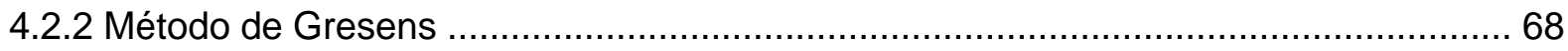

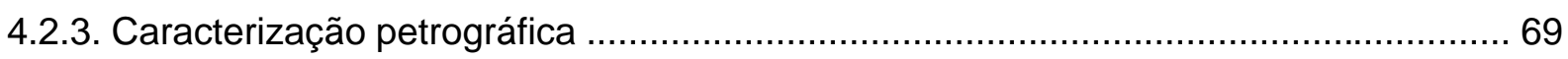

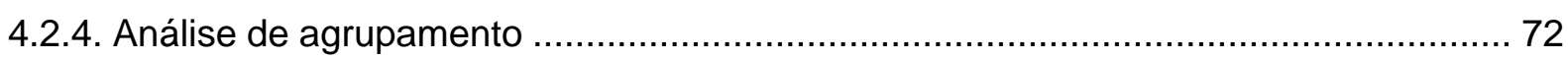


4.2.5. Análise da variação volumétrica e balanço de massas 74

4.3 Análise da geometria da zona de cisalhamento Ribeira 78

4.4 Retroanálise da deformação 83

4.5 Discussão

5. ASPECTOS CONCLUSIVOS 87

5.1. Ensaio sobre a interpretação mecânica da rede de zonas de cisalhamento 87

5.2 Implicações para a evolução da Faixa Ribeira. 91

6. REFERÊNCIAS BIBLIOGRÁFICAS 94

Agradecimentos 105

Este trabalho contém 39 figuras, 9 tabelas e 5 anexos.

ANEXO A - Exemplos de modelagens de deformação finita usando planilhas do MathCad ANEXO B - Tabelas de dados litoquímicos.

ANEXO C - Planilhas de cálculo de variação volumétrica

ANEXO D - Mapa Geológico da Folha Itararé

ANEXO E - Mapa Estrutural da Folha Itararé

Obs.: procurou-se nas equações dos capítulos 2 e 4 indicar variáveis que representem matrizes, vetores e tensores com letras em negrito, e variáveis que representam escalares, inclusive componentes de matrizes, vetores e tensores, com letras normais. 


\section{INTRODUÇÃO}

\subsection{Preâmbulo}

O presente texto foi elaborado com vistas ao concurso de Livre-Docência junto ao Departamento de Mineralogia e Geotectônica do Instituto de Geociências da USP, na área de Geologia Estrutural e Geotectônica, no segundo semestre do ano de 2002. Nele procurou-se rever parte da contribuição dada pelo autor ao conhecimento geológico do Pré-siluriano da região sul do Estado de São Paulo e Leste do Paraná, mas focando especificamente a questão da configuração e da evolução do sistema de zonas de cisalhamento transcorrentes que afetou o embasamento cristalino da região durante o Neoproterozóico e Eopaleozóico.

Obviamente trata-se de uma vasta região e um assunto que engloba múltiplas facetas e enfoques, impossíveis de serem apreendidos por um pesquisador individual. Procurou-se então enfocar o problema sob o ângulo das configurações geométricas do sistema, e como estas configurações podem ou não ser explicadas por alguns dos modelos cinemáticos e dinâmicos disponíveis na literatura, dentro das áreas estudadas pelo autor.

Os dois capítulos iniciais incluem revisões sobre assuntos concernentes ao tema. $O$ primeiro capítulo traz revisões sobre o sistema transcorrente da Região Sudeste do Brasil, e sobre a contextualização dos grandes sistemas transcorrentes na tectônica global. O segundo capítulo mostra a fundamentação teórica para diversos modelos de zonas de cisalhamento e bandas de deformação existentes na literatura. Os capítulos três e quatro tratam da apresentação e discussão de dados do sistema transcorrente e das áreas estudadas. O capitulo três apresenta a configuração geológica regional da porção meridional da Faixa Ribeira, enquanto que o quatro foca a questão da análise da deformação numa parte do Médio Vale do Ribeira. O último capítulo procura abordar alguns aspectos conclusivos.

São ainda incluidos anexos com as planilhas de MathCad utilizadas para modelar diversos aspectos da deformação, tabelas de dados e mapas geológico e estrutural da Folha Itararé (SG22-X-B). 


\subsection{Os cinturões de cisalhamento transcorrentes continentais no contexto da tectônica global.}

As grandes zonas de falhamento ou de deformação cisalhante, com movimentação transcorrente, podem ter comprimentos que chegam a centenas de quilômetros, e varar toda a crosta ou mesmo a litosfera. Exemplos clássicos são as grandes falhas de San Andreas (Califórnia), Great Glenn (Escócia) e Alpina (Nova Zelândia). No Brasil, são consagrados os casos da Província Borborema, com os lineamentos de Patos e Pernambuco, e da Faixa Ribeira, onde a grande estrutura de Cubatão - Além Paraíba - Lancinha configura-se para muitos como o eixo principal de um complexo sistema entrelaçado de zonas de cisalhamento transcorrentes.

$\mathrm{Na}$ escola soviética clássica, hoje pouco considerada, correspondem às falhas profundas, associadas a eventos importantes de magmatismo e hidrotermalismo.

Convém aqui esclarecer o uso que se fará neste texto de alguns termos importantes. Lineamento corresponde a uma feição geomorfológica linear, usualmente observada em fotos aéreas, imagens de sensores remotos ou mapas topográficos. Falha é uma fratura ao longo da qual ocorreu movimento lateral apreciável entre os blocos. Zona de falha corresponde a uma faixa onde os deslocamentos ocorrem ao longo de uma rede de falhas múltiplas. Em termos de obliqüidade (pitch) do seu movimento, as falhas podem ser classificadas como direcionais, de mergulho (dip-slip) ou oblíquas, bem como podem ser classificadas em verticais, inclinadas ou horizontais quanto ao mergulho de seu plano. Mas a classificação mais útil (e utilizada) é a tripartida em normais, transcorrentes e inversas, associada à orientação das direções principais de esforços, e atribuída normalmente a Anderson (1951). Zona, banda ou cinturão de cisalhamento corresponde a uma zona planar de deformação intensa quando comparada aos blocos adjacentes.

No contexto da tectônica de placas os sistemas direcionais tomaram grande importância dentro da definição de falhas transformantes (Wilson, 1965). No deslocamento de placas, configuradas como calotas esféricas no globo terrestre, as falhas transformantes por imposição geométrica, devem obedecer a círculos mínimos em torno de pólos de rotação. As transformantes, além de acomodar o rejeito horizontal entre sistemas de expansão de dorsais oceânicas e/ou sistemas de destruição de assoalho oceânico nas zonas de subducção, constituem com elas um dos tipos básicos de limites de placas ou litosféricos.

No contexto da tectônica de placas, Woodcock e Schubert (1994) consideram, numa escala hierárquica de importância, levando em consideração tanto a profundidade de atuação como o rejeito horizontal, os seguintes grandes sistemas: 1) falhas transformantes associadas a segmentos de dorsais oceânicas; 2) falhas transformantes de borda; 3) transcorrentes associadas a trincheiras; 4) transcorrentes associadas a endentação tectônica; 5) falhas de transferência; e 6) falhas intraplacas. 
As falhas transformantes associadas a dorsais oceânicas ligam dois segmentos de dorsais, e mantém o seu comprimento constante, quando a velocidade de expansão é igual em ambas dorsais.

As falhas transformantes de borda separam placas movendo-se paralelamente a suas bordas sobre centenas de quilômetros. Em geral ligam bordas de placas de diferentes naturezas, freqüentemente mudam seu comprimento durante o tempo, e envolvem crosta continental em uma ou ambas placas limitantes. Podem persistir por dezenas de milhões de anos, e acumular deslocamentos de muitas centenas, ou talvez muitos milhares, de quilômetros. O paradigma é, obviamente, San Andreas (figura 1.1).

As transformantes ou direcionais associadas a trincheiras formam-se em limites convergentes oblíquos. A aproximação oblíqua é resolvida em dois componentes, um de dip-slip na zona de subducção, e outro direcional a ela paralelo. Cortam toda a litosfera e isolam segmentos da própria placa entre ela e a trincheira. Costuma bordejar ou cortar o arco vulcânico. A região de Sumatra e a Falha Alpina na Nova Zelândia encaixam-se no modelo. (figuras 1.2 e 1.3).

As falhas direcionais associadas a endentação tectônica formam-se em zonas de colisão continental. Podem se originar tanto à frente de um promontório de endentação, como lateralmente, através de escape tectônico. Configuram freqüentemente sistemas transcorrentes conjugados. Cortam toda a crosta e mais provavelmente estão confinadas à litosfera. $\mathrm{O}$ paradigma aqui é a colisão do subcontinente indiano com a Ásia (figura 1.4).

As falhas de transferência são falhas direcionais de menor porte e restritas à crosta superior ou à sua cobertura sedimentar. Conectam e compatibilizam os movimentos de falhas maiores de regime contracional ou extensional.

As falhas direcionais intraplacas ocorrem afastadas das bordas de placas, sendo produzidas pelo esforço intraplacas atuando e reativando antigas zonas de fraqueza. Os deslocamentos em geral são relativamente pequenos, podendo produzir rochas e escarpas de falha, bem como podem ser responsáveis por terremotos expressivos. 


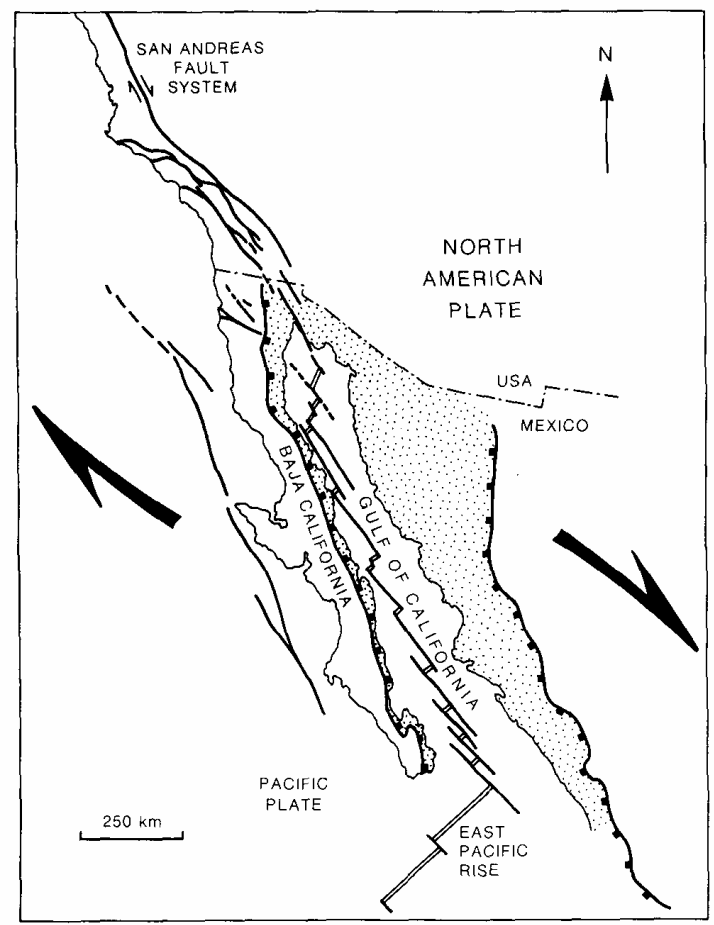

Figura 1.1 - Borda sudeste da placa do Pacífico mostrando as relações entre o sistema destral de San Andreas e dorsal do Pacífico oriental no golfo da Califórnia (Gibbons, 1994, after Stock \& Hodges, 1989)

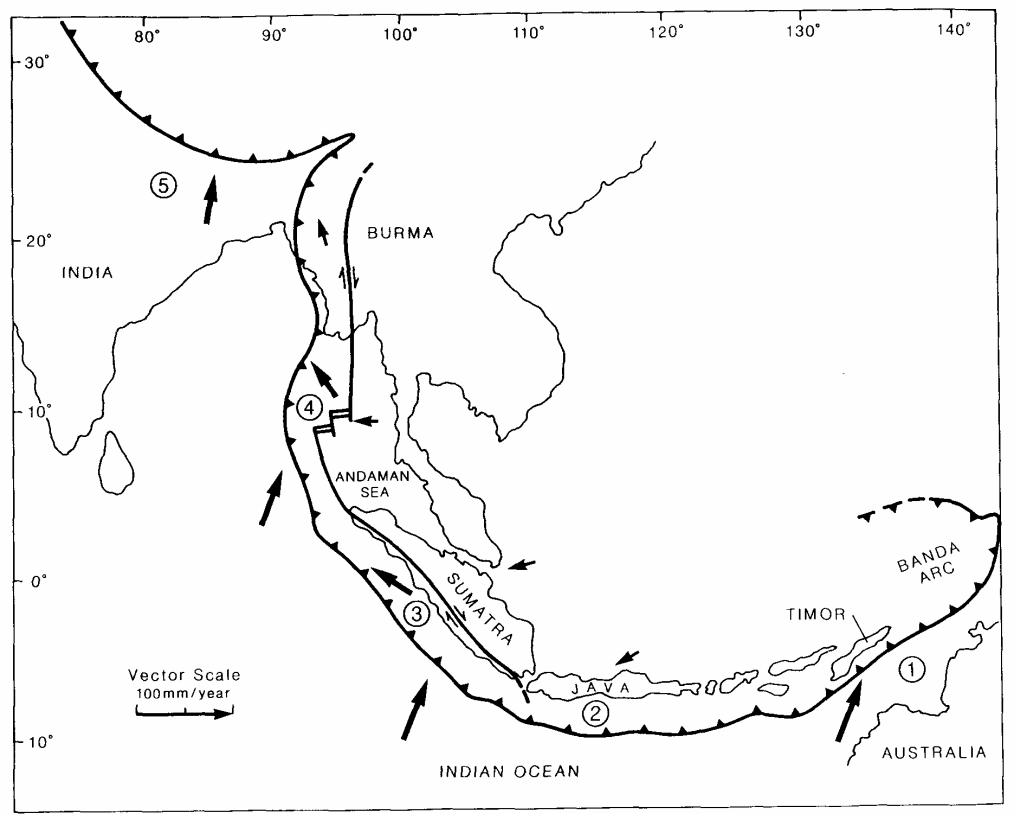

Figura 1.2 - Contexto tectônico da borda leste da placa Índica: (1) colisão continente - arco; (2) subducção frontal de placa oceânica; (3) subducção oblíqua, produzindo um terreno transcorrente entre o arco e a fossa; (4) subducção oblíqua extrema; (5) colisão continental Índia - Ásia (Gibbons, 1994). 


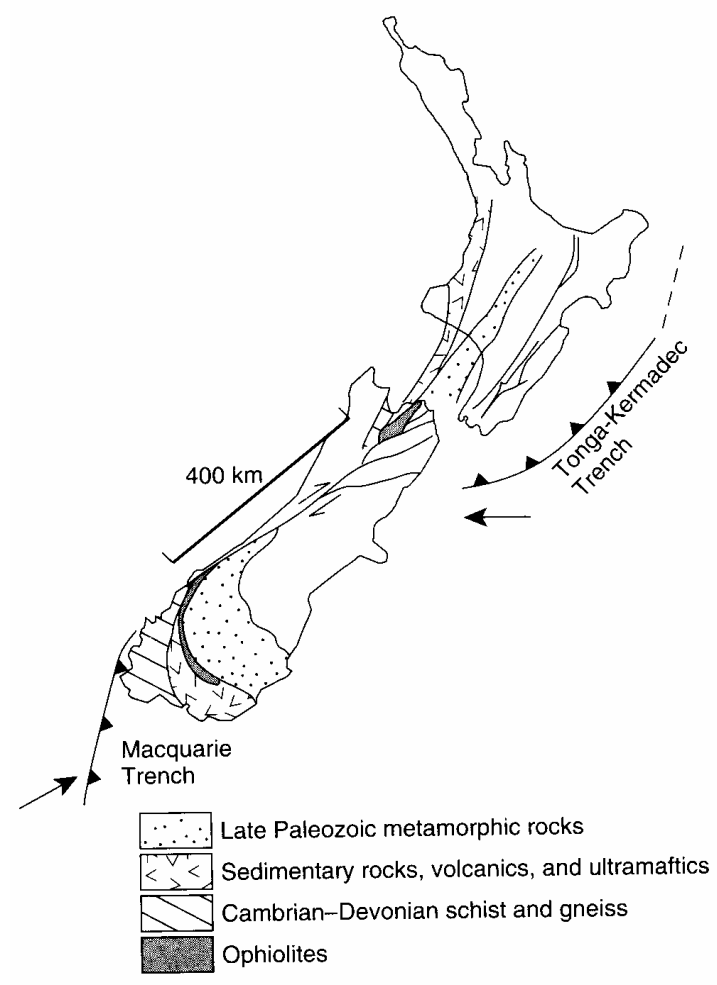

Figura 1.3 - Mapa da Nova Zelândia, mostrando as relações entre a falha Alpina (transcorrente destral) e as zonas de subducção de Tonga - Kermadec, e a de Macquarie (Moores \& Twiss, 1995).

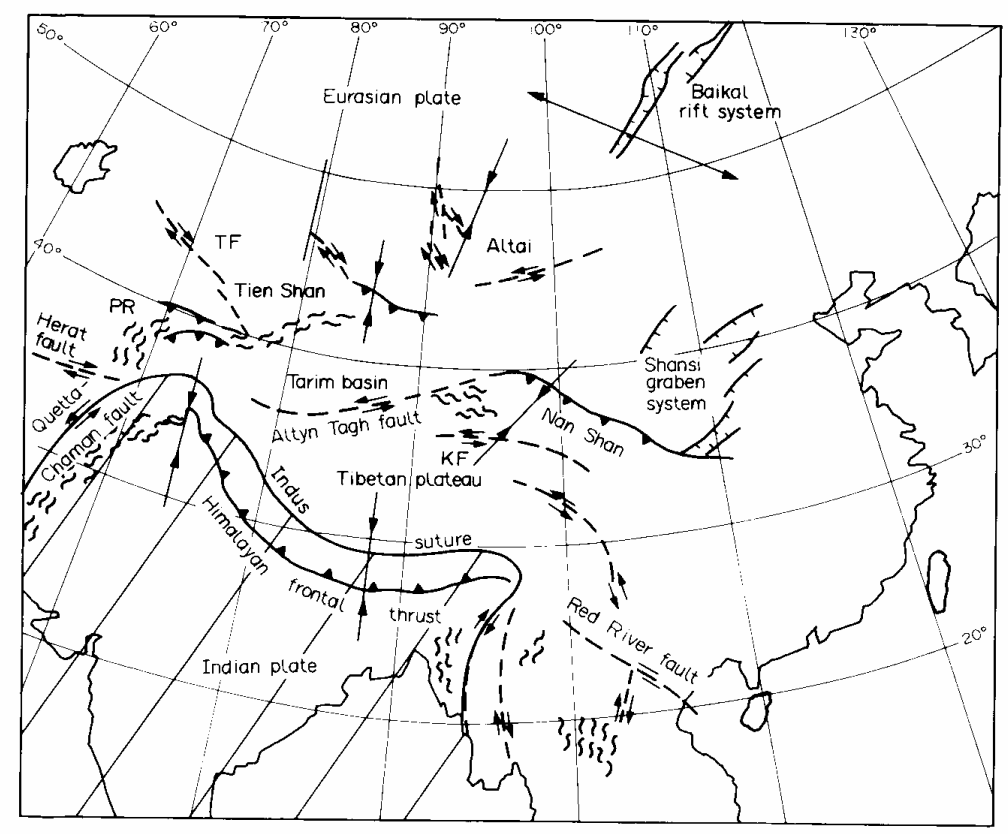

Figura 1.4 - Relações entre a colisão frontal do subcontinente indiana com a Ásia, mostrando a ocorrência de transcorrências devido à indentação tectônica e escape lateral (limites laterais da placa indiana), bem com a ocorrência de transcorrências e extensões intracratônicas na placa eurasiana (Park \& Jaroszewski, 1994, after Molnar \& Tapponnier, 1975) 


\subsection{0 sistema de zonas de cisalhamento da região sudeste do Brasil - Histórico}

O embasamento cristalino da Região Sudeste do Brasil é recortado por uma densa rede de zonas de cisalhamento entrelaçadas. O sistema mais evidente é de caráter transcorrente, predominantemente destral, de natureza dúctil e/ou dúctil rúptil. Possui comprovadamente grande importância na compartimentação litoestrutural, estratigráfica e tectônica da região. Adentra os Estados do Rio de Janeiro, São Paulo, Paraná e Sudeste de Minas Gerais. Para SW, mergulha sob a Bacia do Paraná, e para NE sob o Oceano Atlântico. As faixas de deformação associadas às zonas de cisalhamento individuais podem possuir extensões de até centenas de quilômetros, e larguras da ordem de centenas ou mesmo milhares de metros, delimitadas por vários tipos de rochas miloníticas.

Este sistema já foi denominado como Zona de Transcorrência São Paulo, por Hasui et al. (1975), Faixa Rúptil do Rio Paraíba do Sul, por Braun (1972), Cinturão Transcorrente Paraíba do Sul, por Ebert, Hasui e Costa (1991), e Sistema de Cisalhamento Transatlântico, por Machado Jr. \& Endo (1993).

Os trabalhos pioneiros ocorreram na década de 50. Cabe a Almeida (1955), sob a influência do trabalho de Anderson (1951), a primeira descrição detalhada e identificação de falhamentos transcorrentes na região. Estudando a região da Serra da Cantareira, ao norte da cidade de São Paulo, estabelece aí a existência de um sistema de falhas transcorrentes antigas, profundas, com reativação mais superficial de caráter normal, com o qual relaciona com a geomorfogênese da região e a origem da Bacia Sedimentar de São Paulo. Coutinho (1953) e Franco (1955) descrevem milonitos e ultramilonitos na região de São Roque, SP.

Nas décadas de 60 e 70 o sistema é progressivamente mapeado, dentro do conceito de zonas de falha desenvolvidas em condições superficiais, em regime de ruptura.

Em 1965, Bjonberg, Gandolfi e Paraguassu, em trabalho sobre a região Leste do Estado de São Paulo, afirmam que as falhas de rejeito horizontal prevalecem sobre as falhas normais em extensão. Assinalam a existência de um grande falhamento continuo desde Paratei de Cima até São José dos Campos.

Em 1967, Hennies, Hasui e Penalva descrevem o falhamento transcorrente de Taxaquara, estabelecendo um esquema evolutivo, que mais tarde é generalizado para todo sistema regional de falhamentos transcorrentes. O falhamento de Taxaquara foi descrito inicialmente numa extensão de aproximadamente $100 \mathrm{~km}$, entre a sinéclise do Paraná e a Bacia Sedimentar de São Paulo, cortando em pequeno ângulo as estruturas regionais, rochas ectiníticas e corpos graníticos do Bloco de São Roque, e rochas migmatíticas e granitóides do Bloco Cotia.

Braun (1972) afirma que o Escudo Brasileiro é recortado por zonas de ruptura muito extensas, caracterizando-as como cinturões de rochas extremamente deformadas, com uma trama de falhas onde predominam as de caráter transcorrente de grande extensão, com largas zonas miloníticas. A estruturação geral é representada por falhas aproximadamente paralelas, 
ligadas entre si por falhas menores sigmoidais. A mais notável dessas zonas seria a do Rio Paraíba do Sul, que condiciona o vale desse rio, prolonga-se pelo Estado de São Paulo, sendo coberta pelos sedimentos da Bacia do Paraná e reaparecendo no Rio Grande do Sul.

Na concepção clássica, a evolução pós-brasiliana desses falhamentos está relacionada aos estádios de transição e reativação da Plataforma Brasileira (Sul-Americana), conforme definidos por Almeida (1969). Particularmente na região em foco evoluiu no Mesozóico e Cenozóico um sistema de riftes, denominado Sistema de Riftes da Serra do Mar por Almeida (1976), e Rifte Continental da Região Sudeste do Brasil por Riccomini (1989). Os movimentos verticais que deram origem às feições morfológicas e às bacias tafrogênicas deste sistema de riftes foram acompanhados por intenso magmatismo básico e alcalino. Sua evolução foi fortemente condicionada pela rede de falhamentos transcorrentes estabelecida ao final do Brasiliano, através de sua reativação com caráter normal.

Diversos autores propuseram anteriormente uma origem por falhamento ou Sistema de "Rift valley" para esse conjunto de feições morfológicas e bacias sedimentares associadas (Backheuser, 1926; Maull, 1930; Wasburne, 1930; Paes Leme, 1930; Martonne, 1933; Ruellan, 1944; Freitas, 1944, 1947, 1951a, b, 1956; Almeida, 1953; Ab'Saber \& Bernardes, 1956, etc.)

Nos anos seguintes, diversos pesquisadores realizaram trabalhos de mapeamento geológico sistemático na região, estando a rede de falhamentos transcorrentes em boa parte mapeada ao final da década de 70, em geral em escala de semi-detalhe. Entre eles, destacam-se Hasui et al. (1969), Coutinho (1972), Hasui (1973), Sadowski (1974), Rideg (1974), Algarte et al. (1974), Silva \& Ferrari (1975), Brandalise et al. (1976), Freitas (1976), Carneiro (1977), Hasui et al. (1977a, b, 1978), Costa et al. (1978), Silva et al. (1977, 1978, 1981), etc.

Em 1975, Almeida, Hasui \& Carneiro identificam e descrevem o Lineamento de Além Paraíba. Foi descrito inicialmente num trecho de $150 \mathrm{~km}$, entre a estação Andrade Pinto e proximidades de Itaocara, Estado do Rio de Janeiro. Possui destacada expressão topográfica, sendo caracterizado por larga faixa de blastomilonitos, que atravessa diagonalmente as estruturas da "Série Paraíba" (Rosier, 1965). Segundo os autores, o lineamento descrito corresponde a uma grande falha transcorrente destral, de rejeito desconhecido, bem atestada pela deflexão das estruturas dos blocos adjacentes.

Hasui et al. (1975) propõem a denominação de Zona de Transcorrência São Paulo para a região em questão, constituindo esta um segmento caracterizado por uma complexa rede de falhamentos transcorrentes, dividindo a Região de Dobramentos Sudeste (Almeida et al., 1976) em duas porções (figura 1.5). 


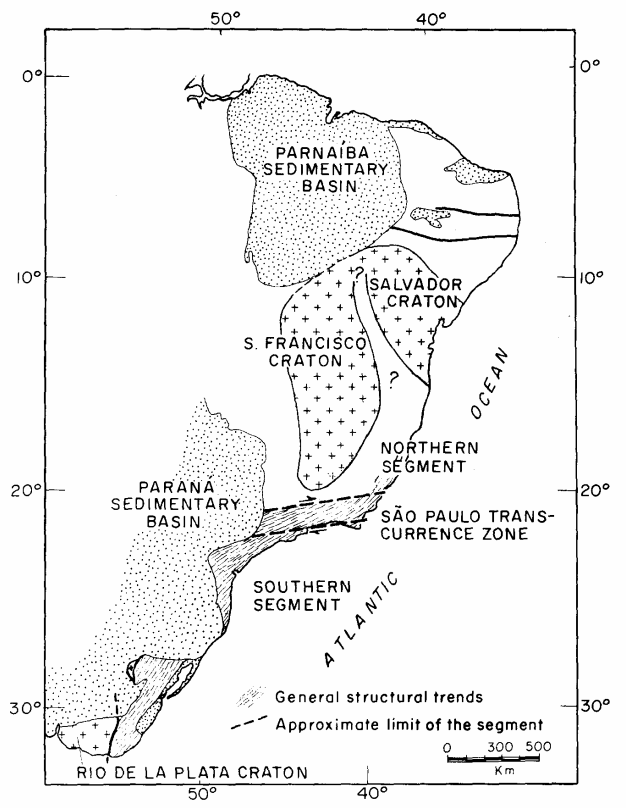

Figura 1.5 - Zona de transcorrência São Paulo, segundo Hasui et al. (1975).

Hasui \& Sadowski (1976) realizaram síntese sobre a geologia e a evolução geológica do Pré-cambriano a SE da cidade de São Paulo, descrevendo sua compartimentação em blocos de falhas. Consideram que os falhamentos ocorreram num nível superficial da crosta, ocasionando fragmentação mecânica das rochas.

Hasui et al. (1977a, b, 1978) apresentam os resultados obtidos por extenso mapeamento na escala 1:100.000 de todo o Leste paulista. Definem a rede de falhamentos transcorrentes e a estruturação da área em blocos tectônicos. Confirmam a seqüência de evolução estrutural desses falhamentos, assim como configurada por Almeida (1955) e Hennies et al. (1967). Sugerem que as intrusões de diabásio e rochas alcalinas possuam um controle estrutural relacionado a esses falhamentos Mapeiam em traços gerais a rede de falhas normais relacionadas às bacias sedimentares tafrogênicas e às feições geomorfológicas. Retificam e fundamentam na estrutura da rede de falhamentos a compartimentação geomorfológica proposta por Almeida (1964).

Indicam que, além de certamente estarem ativas durante o Ciclo Brasiliano e reativadas no Meso-Cenozóico, existem evidencias de que estes falhamentos já estivessem implantados pelo menos no "Pré-cambriano Médio". Os termos litológicos presentes variam de protomilonitos a ultramilonitos e até blastomilonitos. Em alguns trechos, apresentam fatias embutidas de xistos, interpretadas como encaixadas dentro das zonas de falhas pela componente vertical do rejeito. Os maiores falhamentos são os de Taxaquara (possivelmente prolongando-se no de Além Paraíba, de Almeida et al., 1975). Cubatão (unindo-se ao de Taxaquara), Alto de Fartura (continuando no de Rio Preto, Minas Gerais), Buquira e Jundiuvira. Todos se caracterizam por uma zona de rochas de falha de mais de $1.000 \mathrm{~m}$ de espessura. Supondo verdadeira a continuidade entre os falhamentos de Taxaquara, Cubatão e Além Paraíba estes corresponderiam à mais extensa estrutura desse tipo na região. 
Diversos autores mantiveram a proposição da continuidade entre os lineamentos de Além Paraíba, Cubatão, Itapeúna e Lancinha, o que configuraria uma zona de cisalhamento com extensão superior a $1.000 \mathrm{~km}$, e que se constituiria no eixo principal do sistema (Sadowski \& Motidome, 1987). Já Almeida (2000) propõe que no Estado do Rio de Janeiro a zona de cisalhamento Arcádia - Areal seria um limite crustal mais importante, tendo possível continuidade para São Paulo na falha Sertão dos Freires, que unir-se-ia ao lineamento de Cubatão a SE da cidade de São Paulo.

Seja como for, o lineamento de Cubatão representa também um limite entre blocos crustais com diferentes assinaturas gravimétricas (Davino et al., 1986; Campanha et al., 1988; Campanha, 1991). Hasui et al. (1989) e Quintas (1995) propõem sua continuidade, bem como a do lineamento de Jacutinga, por sob a Bacia do Paraná.

A partir da década de 80, passa a entrar em voga na interpretação dessas estruturas na região o conceito de zonas de cisalhamento dúctil, proposto na sua conceituação atual por Ramsay \& Graham (1970). São pioneiros na aplicação desse conceito na região os trabalhos de Campanha (1980, 1981) e Sadowski (1980).

Baseados neste modelo, Sadowski (1983), Fiori (1985b) e Campanha (1991) realizaram cálculos dos rejeitos das zonas de cisalhamento do Sul do Estado de São Paulo e Leste do Paraná.

Também no começo da década de 80 surge o modelo de sobreposição de duas fases de cisalhamento dúctil na região, uma tangencial, de baixo ângulo, sobreposta por outra de alto ângulo, transcorrente e destral. São pioneiros nesta interpretação os trabalhos de Trouw et al. (1982), Hasui (1983), Campos Neto, Basei \& Alves (1984)

Modelos de evolução mecânica e cinemática de porções dos sistema transcorrente, essencialmente dentro do modelo de ruptura, são propostos por Silva (1981), Silva, Sadowski, Trompette (1982), Fassbinder, Sadowski e Fiori (1994).

$\mathrm{Na}$ década de 90, diversos autores passam a propor um regime transpressivo para a deformação associada ao sistema transcorrente, com o desenvolvimento de mega-estruturas em flor. Destacam-se aí os trabalhos de Sadowski (1991), Ebert, Hasui \& Costa (1991), Hackspacher et al. (1992), Machado \& Endo (1993), Correa Neto et al. (1993), Campanha \& Ens (1993), Fassbinder (1996), etc..

Particularmente no médio vale do rio Paraíba do Sul reconhece-se uma estruturação regional em leque aberto, com as porções centrais fortemente verticalizadas, já identificada por Lamego (1938, 1946). Foi interpretada como uma mega-estrutura em flor positiva (Machado \& Endo, op. cit.), e como uma estrutura sinclinorial (Lamego, op. cit., Heilbron, 1993, 1995, Trouw, 1995, Almeida, 2000).

Passa também a ser sugerida a associação da colocação dos granitos da região dentro de modelos transpressivos / transtracionais (e.g., Fassbinder, Fumagalli, Fiori, 1985, Machado \& Demangé, 1994, Hackspacher, 1994, Nummer, 2001) 
Embora existam sugestões de uma ativação transamazônica dessas estruturas (Campanha, 1980, 1981; Fassbinder, 1990), esta questão não é clara. Localmente são citadas evidências de movimentações ou fases sinistrais (e.g., Garcia \& Campos Neto, 1997), e mesmo o predomínio desta componente nos terrenos a sul de Lancinha - Cubatão (Vasconcelos et al., 1999, Campanha et al., 2001, Dias Neto, 2001).

Em termos de um modelo geodinâmico, têm sido proposta uma colisão oblíqua entre os crátons do Congo, São Francisco e Paraná, gerando uma tectônica de escape (Vauchez et al., 1992; 1994), ou entre os blocos Vitória, Paraná e São Paulo (Hasui et al., 1989, Ebert et al., 1993, Ebert \& Hasui, 1998), como geradora do sistema transcorrente.

A Faixa Ribeira passa a ser considerada como um cinturão de cisalhamento transcorrente que articula as interações entre a Faixa Brasília (Província ou Sistema Orogênico Tocantins), o Cráton do São Francisco e uma série de terrenos acrescidos a sul (Campos Neto, 1999, 2000)

O sistema transcorrente atuou pelo menos até a crosta inferior, permanecendo ainda em posição empinada, conforme atestado pelas condições de recristalização dos milonitos do Lineamento de Além Paraíba (Almeida et al., 1975, Campanha, 1980, 1981; Silva \& Mainprice, 1999, Silva et al. 2002). Os estudos de anisotropia sísmica na região (James \& Assumpção, 1996, Assumpção et al., 2001) têm sugerido que a foliação empinada e lineação sub-horizontal que caracterizam o sistema varam toda a crosta e alcançam mesmo o manto superior. Trata-se então de uma estrutura de escala litosférica, devendo ter se constituído em limite de placas quando de sua formação.

\subsection{A configuração geométrica do sistema}

O Sistema de zonas de Cisalhamento da Região Sudeste do Brasil é constituído por um cinturão com cerca de 1000 a 1100 km de comprimento exposto, com orientação ENE, defletindo estruturas NS que vem da Bahia, Leste de Minas e Espírito Santo, bem como do Sul do Brasil e Uruguai. Caracteriza-se como um feixe anastomosado de zonas de cisalhamento transcorrentes, predominantemente destrais, definindo lentes sigmoidais de cisalhamento nas mais diferentes escalas.

Numa visão abrangente, articula a justaposição entre os crátons do São Francisco, Paraná, Luís Alves e do Congo ao final do Neoproterozóico e no Cambro-ordoviciano.

Entre esses fragmentos cratônicos podem ser reconhecidos uma série de terrenos, no sentido inaugurado pelo sãofranciscano na Califórnia, limitados em geral por importantes zonas de cisalhamento transcorrentes.

São reconhecidos de norte para sul a Nappe do Guaxupé, o Alto Rio Grande, Nappe do Socorro, Juiz de Fora, Ribeira (incluindo o Apiaí, Embu e Paraíba do Sul), Serra do Mar, Cabo Frio, Curitiba e Luís Alves. As zonas de cisalhamento transcorrentes que delimitam esses blocos são as de Campo do Meio, Jacutinga - Ouro Fino, Jundiuvira - Boquira - Rio Preto, Cubatão Lancinha e Faxinal - Morretes. 


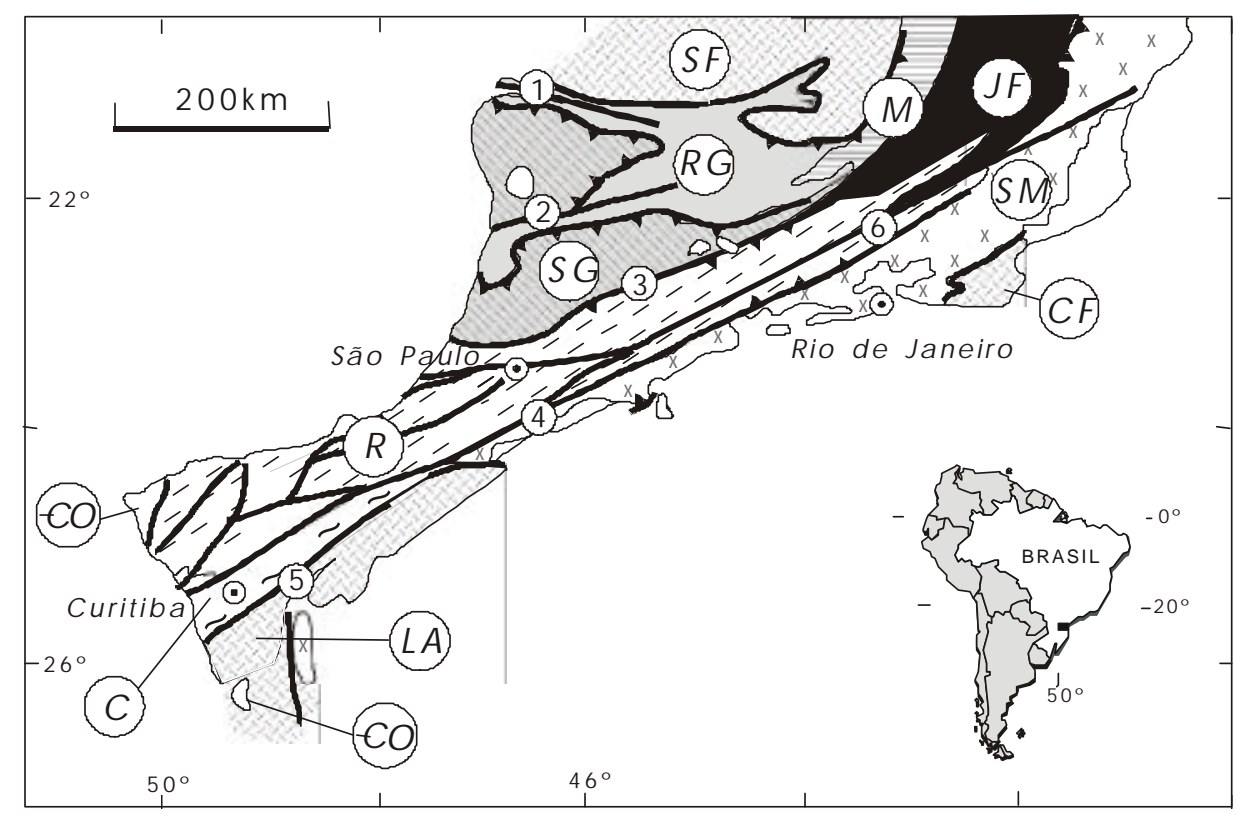

Figura 1.6 - Principais unidades tectônicas pré-silurianas do Sudeste brasileiro e zonas de cisalhamento limitantes. Blocos e fragmento cratônicos: (LA) Luís Alves, (CF) Cabo Frio, (SF) São Francisco. Terrenos arqueanos e paleoproterozóicos de alto grau retrabalhados no Brasiliano: (C) Curitiba, (SM) Serra do Mar, (JF) Juiz de Fora, (M) Mantiqueira. Faixas de dobramento meso a neoproterozóicas: (RG) Alto Rio Grande, (R) Ribeira. (SG) Nappe Socorro - Guaxupé. Seqüências sedimentares e vulcanossedimentares Cambro-ordovicianas (CO). Zonas de cisalhamento: (1) Campos do Meio; (2) Jacutinga - Ouro Fino; (3) Jundiuvira - Boquira - Rio Preto; (4) Cubatão; (5) Lancinha; (6) Além Paraíba.

Limites crustais particularmente importantes tem sido atribuídos às zonas de cisalhamento de Jundiuvira / Boquira / Rio Preto a norte, e de Lancinha / Cubatão ao sul. Estas duas megaestruturas delimitam um cinturão central com estruturação empinada, com relação aos blocos adjacentes, nos quais predomina, tanto a norte como a sul, uma estruturação dada por zonas de cisalhamento de baixo ângulo.

Mais para norte, a zona de cisalhamento Campo do Meio (sinistral) e a de Jacutinga / Ouro Fino delimitam a Nappe ou Cunha do Guaxupé.

O setor central, delimitado por Jundiuvira e Cubatão, com cerca de 50 a 100 km de largura, caracteriza-se predominantemente por foliações empinadas, lineações de estiramento subhorizontais, e indicadores cinemáticos predominantemente destrais. É constituído por um feixe de zonas de cisalhamento transcorrentes anastomosadas, com larguras individuais de metros a dezenas de metros no extremo SW, até vários quilômetros no extremo leste (Além Paraíba). Os blocos e lentes sigmoidais delimitados por essas zonas de cisalhamento mostram em geral uma assimetria indicativa do movimento destral dominante. Predominam neste cinturão central as 
rochas metassedimentares e metavulcanossedimentares normalmente atribuídas à Faixa Ribeira, como aquelas incluídas nos grupos Açungui e São Roque, complexos Embu e Paraíba do Sul.

Grandes batólitos graníticos alongados, com até pouco mais de $200 \mathrm{~km}$ de comprimento, e com até 30 a $50 \mathrm{~km}$ de largura intrudem as seqüências supracrustais e seu embasamento. São seguidas por intrusões graníticas alcalinas, em geral menores e mais circunscritas do que as anteriores.

Se na porção central a estruturação geral é empinada, para as bordas ela tende a ter mergulhos moderados a baixos para o centro, configurando uma estrutura divergente, sugestiva de uma macro-flor positiva ou uma estrutura sinclinorial, dependendo da opinião de cada autor. Para as porções externas ocorrem inclusive largas áreas com foliação sub-horizontal, por vezes interpretadas como nappes (de colocação profunda).

Pequenas bacias de sedimentação ocorrem em geral associadas às zonas transcorrentes. São exemplos típicos as formações Eleutério, Pouso Alegre, Pico de Itapeva, Quatis e Camarinha, com preenchimento sedimentar essencialmente clástico, grau metamórfico muito baixo, camadas empinadas, mas não claramente dobradas, localmente com clivagens ardosianas muito finas e elongação de seixos. Em todos estes casos, mostram-se pelo menos em parte limitadas por zonas de cisalhamento direcionais, com depósitos rudáceos nessas bordas, com fragmentos das rochas aflorantes imediatamente adjacentes, incluindo milonitos das zonas de cisalhamento, geometria alongada em sua direção, e estiramento sub-horizontal de seixos. O Conglomerado Samambaia, mostra características litológicas semelhantes, enquanto que a ocorrência de Cajamar é a única com depósitos carbonáticos; nestes dois casos as áreas de exposição são muito restritas, não permitindo uma observação direta das relações com o sistemas transcorrente. Já o Grupo Castro, e as formações Guaratubinha e Campo Alegre, mais ao sul, mostram um preenchimento essencialmente vulcânico e vulcanossedimentar. Estas duas últimas situam-se sobre o fragmento cratônico de Luís Alves, mostrando uma geometria basinal simples e aparentemente preservada, praticamente sem metamorfismo e deformação dúctil. O Grupo Castro, embora com características litológicas semelhantes, situa-se sobre o terreno Apiaí, tendo seu limite com esse bloco dado por zona de cisalhamento NNE, aparentemente direcional e sinistral, caracterizando eventualmente uma bacia transtracional. Classicamente, todos estes depósito foram interpretados como molassas do Ciclo Brasiliano (Almeida, 1967).

O sistema está exposto em diferentes níveis crustais de atuação, conforme demonstrado pelas associações metamórficas recristalizadas na matriz dos milonitos, e pela própria largura das faixas de deformação, em tese maiores quanto mais profundo o seu nível de atuação. A grosso modo, varia desde alto grau (até fácies granulito) no Lineamento de Além Paraíba, no Rio de Janeiro, passando a fácies xistos verdes alto a anfibolito no Vale do Paraíba, no Estado de São Paulo, e chegando a baixo grau, talvez na transição rúptil - dúctil, no sul do Estado de São Paulo e no Estado do Paraná. 
Apesar desta visão generalizada da variação no nível crustal ser correta numa primeira aproximação, a estrutura e a evolução reais do sistema parecem ser mais complexas. Principalmente ao longo dos lineamentos de Além Paraíba e Cubatão, ocorrem embutimentos de rochas de dferentes níveis crustais com relação aos blocos adjacentes, na forma de fatias de rochas extremamente longilíneas. Na porção mediana do Lineamento de Além Paraíba ocorrem rochas de associação charnockítica, ladeadas por blocos adjacentes com migmatitos e gnaisses de fácies anfibolito. Ao longo do lineamento de Cubatão, desde o baixo Vale do Ribeira até o Vale do Paraíba, ocorre uma longa e estreita fatia de rochas supracrustais, de grau mais baixo que as encaixantes. Modelos para estes embutimentos foram propostos respectivamente por Correa Neto et al. (1993) e Silva (1981). 


\section{FUNDAMENTAÇÃO TEÓRICA}

Os modelos existentes na literatura sobre o desenvolvimento de zonas de cisalhamento baseiam-se em geral na conceituação de deformação, e suas implicações geométricas e cinemáticas. Alguns poucos modelos levam em conta o estado de tensões e as respostas dos materiais a essas tensões aplicadas.

A análise da deformação na sua forma mais geral é uma tarefa matematicamente complexa e laboriosa. Algumas abordagens diferentes para a questão têm sido adotadas na literatura.

Um caminho é o adotado por livros como Ramsay (1967) e Jaeger (1969), de grande influência no meio da geologia estrutural, que é o de evitar o desenvolvimento matemático do assunto por meio de matrizes e tensores, preferindo o desmembramento em equações algébricas usuais. A vantagem desta abordagem é que não exige um embasamento matemático do leitor maior do que é dado ao nos primeiros anos dos cursos de graduação na área de ciências exatas. Este tipo de abordagem tem sido bem sucedido quando se adota algumas simplificações ou casos especiais. Como por exemplo, a restrição da análise a uma situação bidimensional, à qual a deformação em três dimensões pode ser reduzida quando um dos eixos principais não sofre deformação (caso em geral denominado como deformação plana, tal como o cisalhamento simples e o cisalhamento puro), ou quando duas deformações principais são iguais (deformação bi-axial). Outra simplificação usualmente feita é adotar-se um sistema de referência paralelo aos eixos principais de deformação, eliminando-se assim a componente de rotação desses eixos. As equações do círculo de Mohr por exemplo adotam este tipo de pressuposto.

Porém, quando se procura analisar a deformação em três dimensões, sem este tipo de restrição, torna-se necessário manipular sistemas com até dezenas de equações, com até dezenas de termos cada uma, dificultando ou mesmo inviabilizando a análise. Neste caso a ferramenta matemática mais adequada é o uso de matrizes e tensores e, no caso ainda mais complexo da deformação heterogênea, o cálculo tensorial (cálculo dferencial e integral aplicado para matrizes e tensores). Este é o caminho adotado por exemplo por Nye (1957), Means (1976), Oertel (1996), Ramsay \& Lisle (2000) e, em um nível mais avançado, por Malvern(1969) e Truesdell \& Toupin (1960).

Antes do advento dos computadores, as ferramentas matemáticas do cálculo tensorial eram de relativa pouca aplicação prática, em função do caráter extremamente laborioso das operações necessárias, envolvendo procedimentos como multiplicação e inversão de matrizes, cálculo de autovalores e autovetores, etc.

Com um microcomputador disponível, mesmo que antigo e pouco potente, estas tarefas tornam-se viáveis. Em qualquer linguagem de programação, e mesmo com planilhas eletrônicas, fazer operações com matrizes e cálculos repetitivos é relativamente simples. Existem ainda ferramentas mais fáceis de serem utilizadas, como aqueles programas voltados especificamente à 
realização de cálculos e modelagens matemáticas. No Anexo A, mostramos algumas planilhas e rotinas desenvolvidas com o programa Mathcad Professional versão 8, disponível na USP.

\subsection{Análise tensorial de deformação}

O desenvolvimento que se fará em seguida pode ser referenciado basicamente ao livro de Malvern (1969), porém com o apoio dos livros mais "básicos" de Means (1976), Nye (1957) e Oertel (1996).

\subsubsection{Deformação finita homogênea}

A deformação finita é definida pela comparação da forma geométrica dos corpos em dois estados: um inicial, antes da deformação, e outro final, após a deformação.

Uma deformação genérica pode ser decomposta em termos de quatro componentes:

- Translação de corpo rígido

- Rotação de corpo rígido

- Distorção de forma

- Variação de volume

Para sua especificação, definimos um sistema triortogonal de eixos $\left(x_{1}, x_{2}, x_{3}\right)$ ao invés da notação mais tradicional de $(x, y, z)$.

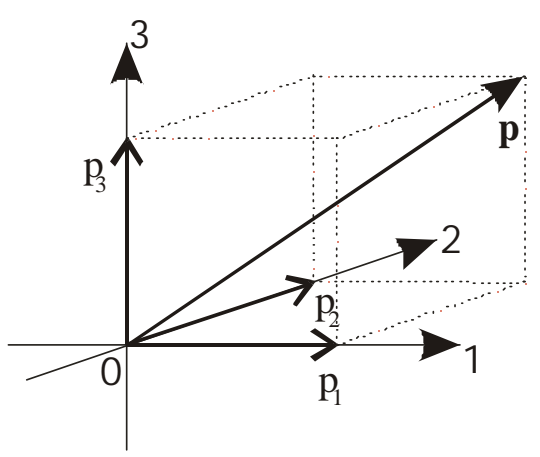

Figura 2.1 Sistema de referência adotado, com três eixos cartesianos 01, 02, 03.

onde a posição de um determinado ponto é definida pelo seu vetor posição p, e seus componentes nestes eixos: $\mathbf{p}=\left[\begin{array}{l}p_{1} \\ p_{2} \\ p_{3}\end{array}\right]$. Usaremos símbolos em negrito para denotar vetores, matrizes e tensores, e símbolos normais para denotar escalares, inclusive os componentes de matrizes, vetores e tensores. 
A deformação pode ser analisada pela variação dos vetores posição entre os estados inicial e final. Usaremos letras maiúsculas para o estado inicial, indeformado, e minúsculas para o estado final, deformado. Por simplicidade, ilustra-se abaixo em duas dimensões.
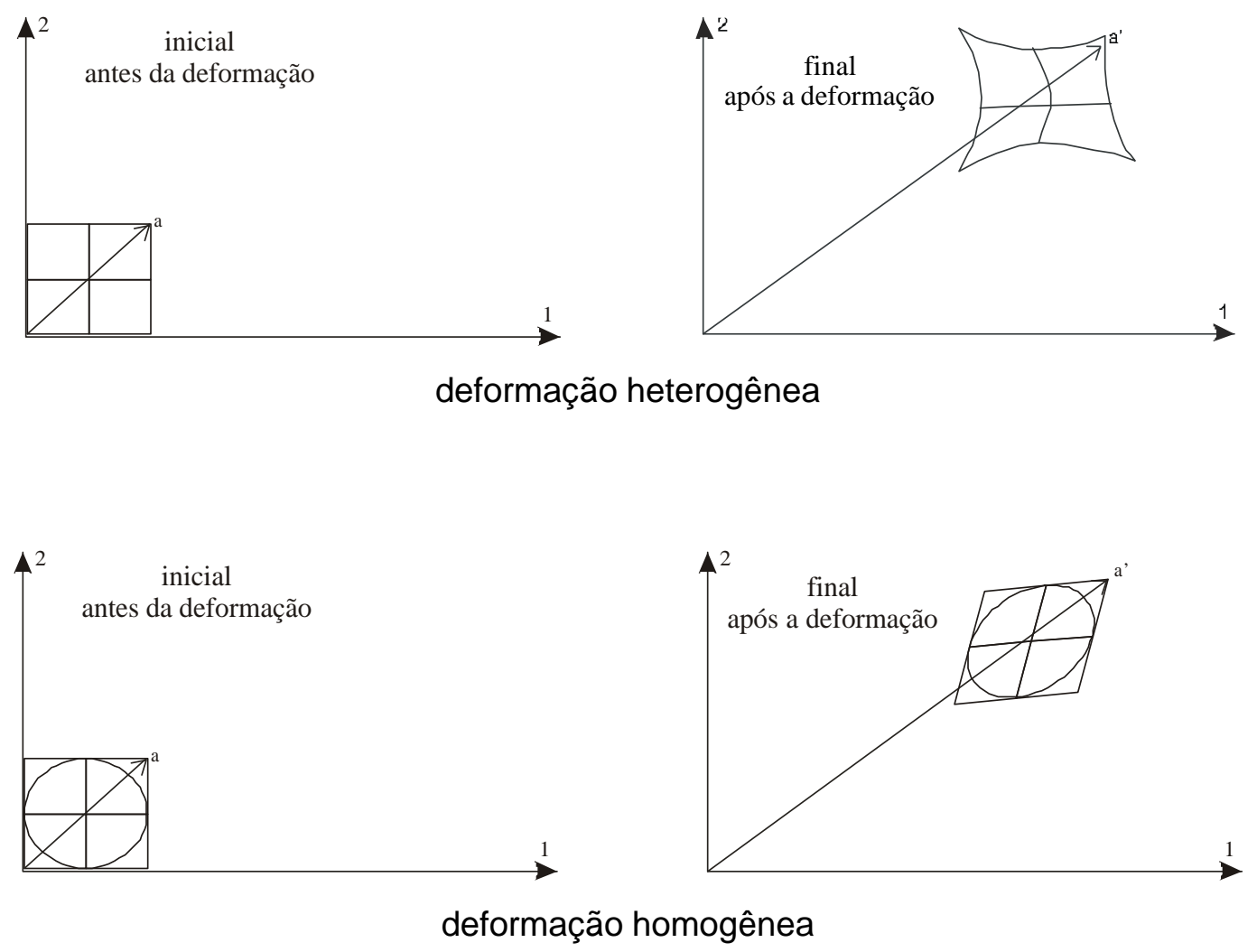

Figura 2.2 Ilustração da deformação como a variação da posição dos pontos que compõem o continuum de um corpo, antes e depois da deformação.

Pode-se discriminar as posições finais dos pontos que compõem o continuum dos corpos, em termos de suas posições finais $\left(x_{1}, x_{2}, x_{3}\right)$ em função de suas posições iniciais $\left(\mathrm{X}_{1}, \mathrm{X}_{2}, \mathrm{X}_{3}\right)$ :

$$
\begin{aligned}
& \mathrm{X}_{1}=\mathrm{F}_{1}\left(\mathrm{X}_{1}, \mathrm{X}_{2}, \mathrm{X}_{3}\right) \\
& \mathrm{X}_{2}=\mathrm{F}_{2}\left(\mathrm{X}_{1}, \mathrm{X}_{2}, \mathrm{X}_{3}\right) \\
& \mathrm{X}_{3}=\mathrm{F}_{3}\left(\mathrm{X}_{1}, \mathrm{X}_{2}, \mathrm{X}_{3}\right)
\end{aligned}
$$

Na deformação homogênea, $F_{1}(), F_{2}(), F_{3}($ ) serão equações lineares, na forma geral:

$$
\begin{aligned}
& \mathrm{X}_{1}=\mathrm{aX} \mathrm{X}_{1}+\mathrm{b} \mathrm{X}_{2}+\mathrm{cX} \mathrm{X}_{3}+\mathrm{t}_{1} \\
& \mathrm{X}_{2}=\mathrm{dX_{1 }}+\mathrm{eX_{2 }}+\mathrm{fX}_{3}+\mathrm{t}_{2} \\
& \mathrm{X}_{3}=\mathrm{g} \mathrm{X}_{1}+\mathrm{hX_{2 }}+\mathrm{iX_{3 }}+\mathrm{t}_{3}
\end{aligned}
$$


onde $t_{1}, t_{2}, t_{3}$ são componentes de translação ao longo dos eixos $1,2,3$ e poderão normalmente ser desprezados.

As equações acima podem ser, então, escritas na forma matricial:

$$
\left[\begin{array}{l}
x_{1} \\
x_{2} \\
x_{3}
\end{array}\right]=\left[\begin{array}{lll}
a & b & c \\
d & e & f \\
g & h & i
\end{array}\right] \cdot\left[\begin{array}{l}
X_{1} \\
X_{2} \\
X_{3}
\end{array}\right]
$$

E de forma compacta:

$$
\mathbf{X}=\mathbf{F} \cdot \mathbf{X}
$$

Com os símbolos em negrito representando as matrizes.

Também é possível reescrevê-la segundo a notação indicial, onde estão representados os componentes de cada matriz:

$$
x_{i}=F_{i j} \cdot X_{j}
$$

onde os índices indicam a posição do componente nas matrizes (i sendo a linha, j sendo a coluna, ambos variando de $1,2,3$ ). A repetição de um índice no mesmo termo (no caso j), significa soma com relação a esse índice.

A matriz $\mathbf{F}$, chamada matriz de transformação, representa a deformação, e será no caso genérico assimétrica.

Caso um estado de deformação representado pela matriz de transformação $\mathbf{F}$ seja considerado o resultado da sobreposição de duas deformações, representadas pelas matrizes F1 (primeira deformação) e F2 (segunda deformação), a matriz F resultante será dada pela multiplicação:

\section{$F=F 2 \cdot F 1$}

Lembrando sempre que a multiplicação matricial é uma operação não comutativa, e portanto a ordem dos fatores deve ser sempre estritamente observada.

Como conseqüência, a sobreposição de duas deformações também será uma operação não comutativa: 
A variação de volume $F_{v}$ associada à deformação pode ser calculada pelo determinante de $\mathbf{F}$ :

$$
F_{V}=\frac{V_{F}}{V_{I}}=\operatorname{det} \mathbf{F}
$$

onde $V_{F}$ é o volume final e $V_{\text {I }}$ é o volume inicial.

Notar que o fator volumétrico aqui usado é

$$
\mathrm{F}_{\mathrm{V}}=\mathrm{V}_{\mathrm{F}} / \mathrm{V}_{\mathrm{l}}
$$

enquanto que a variação volumétrica (dilatação) $\Delta \mathrm{V}$ utilizada por Ramsay é

$$
\Delta \mathrm{V}=\left(\mathrm{V}_{\mathrm{F}}-\mathrm{V}_{\mathrm{l}}\right) / \mathrm{V}_{1}
$$

e portanto

$$
\mathrm{F}_{\mathrm{V}}=\Delta \mathrm{V}+1
$$

Como o volume final $V_{F}$ não pode ser zero, nem infinito, e nem um corpo material pode ser invertido especularmente, devemos ter que $\infty>\operatorname{det} \mathbf{F}>0$.

A componente simétrica, não rotacional da deformação, incluindo a distorção de forma e a variação de volume, pode ser obtida por diversos procedimentos.

Define-se por exemplo o Tensor de Green $\mathbf{C}$ pela relação:

$$
\mathbf{C}=\mathbf{F} \cdot \mathbf{F}^{\top}
$$

onde $\mathbf{F}^{\top}$ é a matriz transposta de $\mathbf{F}$.

A matriz $\mathbf{C}$ fornece a elongação quadrática $\lambda$ de uma linha na direção de um vetor unitário com orientação $\mathbf{X}=\left(\mathrm{X}_{1}, \mathrm{X}_{2}, \mathrm{X}_{3}\right)$, no estado inicial indeformado, pela relação matricial:

$$
\lambda=\mathbf{X}^{\top} \cdot \mathbf{C} \cdot \mathbf{X}
$$

sendo

$$
\lambda=\left(\frac{l_{\mathrm{F}}}{l_{\mathrm{i}}}\right)^{2}
$$

onde $\quad l_{i}$ é o comprimento inicial da linha e $l_{F}$ é o comprimento final. 
Os autovetores de $\mathbf{C}$ fornecem as orientações das linhas que compõem os eixos principais de deformação no estado indeformado, e os seus autovalores fornecerão as elongações quadráticas principais $\left(\lambda_{1}, \lambda_{2}, \lambda_{3}\right)$ associadas a esses eixos.

Define-se também o Tensor de Cauchy c (minúsculo) pela relação

$$
\mathbf{C}=\left(\mathbf{F}^{-1}\right)^{\top *} \mathbf{F}^{-1}
$$

onde $\mathbf{F}^{-1}$ indica a matriz inversa de $\mathbf{F}$.

A matriz c fornece a elongação quadrática recíproca $\lambda^{\prime}(1 / \lambda)$ de uma linha na direção de um vetor unitário com orientação $\mathbf{x}=\left(\mathrm{x}_{1}, \mathrm{x}_{2}, \mathrm{x}_{3}\right)$, no estado final deformado, pela relação matricial:

$$
\lambda^{\prime}=\mathbf{x}^{\top} \cdot \mathbf{c} \cdot \mathbf{x}
$$

Os autovetores de c fornecem as orientações das linhas que compõem os eixos principais de deformação no estado deformado, e os seus autovalores fornecerão as elongações quadráticas recíprocas principais $\left(1 / \lambda_{1}, 1 / \lambda_{2}, 1 / \lambda_{3}\right)$ associadas a esses eixos.

As matrizes (tensores) C e c descrevem o componente simétrico, não rotacional da deformação, denominado de strain pela maioria dos autores.

É conveniente neste momento a definição dos tensores de extensão (strech).

Dada uma matriz $\mathbf{F}$, assimétrica, representando uma deformação geral, esta pode ser decomposta como se segue:

$$
\mathbf{F}=\mathbf{R} \cdot \mathbf{U}=\mathbf{V} \cdot \mathbf{R}
$$

onde $\mathbf{R}$ é uma matriz de transformação denotando uma rotação de corpo rígido. $\mathbf{U}$ e $\mathbf{V}$ são matrizes de transformação simétricas positivas, denominadas tensor de extensão direito (U) e tensor de extensão esquerdo (V).

O tensor de extensão direito está associado ao estado indeformado e pode ser assim obtido:

$$
\mathbf{U}=\sqrt{\mathbf{C}}=\sqrt{\mathbf{F}^{\top} \cdot \mathbf{F}}
$$

entendendo-se como raiz de $\mathbf{C}$ uma matriz tal que:

$$
\mathbf{U} \cdot \mathbf{U}=\mathbf{C}
$$

O tensor de extensão esquerdo está associado ao estado deformado, e é definido como: 


$$
\mathbf{V}=\sqrt{\mathbf{c}^{-1}}=\sqrt{\mathbf{F} \cdot \mathbf{F}^{\top}}
$$

O tensor $\mathbf{V}$ terá os mesmos autovetores que c, que serão os eixos principais de deformação no estado final. Porém seus autovalores fornecerão as extensões principais $\left(S_{1}, S_{2}\right.$, $S_{3}$ ), que correspondem ao tamanho dos semi-eixos do elipsóide de deformação, sendo a extensão $S$ definida como

$$
\mathrm{S}=\left(\mathrm{I} / \mathrm{I}_{\mathrm{i}}\right)
$$

Os valores de $\mathrm{S}$ tomados em todas as direções definem o elipsóide de deformação finita. É comum na literatura geológica denominar-se as direções principais (eixos principais do elipsóide) deformação como $\mathbf{X}, \mathbf{Y}, \mathbf{Z}$, associados respectivamente às extensões principais maior, intermediária e menor.

Os vários formatos de elipsóides podem ser representados pelo Diagrama de Flinn, onde define-se um fator de forma $\mathrm{K}$ tal que:

$$
K=\left(S_{1} / S_{2}-1\right) /\left(S_{2} / S_{3}-1\right)
$$

Similarmente, os autovalores de $\mathbf{U}$ fornecerão as extensões principais recíprocas, ou seja, os comprimentos dos semi-eixos do elipsóide de deformação recíproca. Os seus autovetores fornecerão os eixos principais do elipsóide de deformação recíproca, ou seja, as orientações dos eixo principais de deformação no estado indeformado. Os eixos obtidos serão os mesmos que aqueles calculados a partir do tensor de Green (C).

A matriz $\mathbf{R}$ representa uma de transformação que produz a rotação das linhas que compõem os eixos principais de deformação, entre o estado inicial, antes da deformação, e o final, após a deformação.

Caso a deformação seja não-rotacional, ou seja, os eixos principais tenham a mesma orientação antes e depois da deformação, $\mathbf{R}$ será a matriz unitária, e $\mathbf{F}=\mathbf{V}$.

A matriz de rotação $\mathbf{R}$ pode ser dada em função de $\mathbf{F}$ :

$$
\mathbf{R}=\mathbf{V}^{-1} \cdot \mathbf{F}
$$

Onde $\mathbf{V}^{-1}$ seria a matriz inversa de $\mathbf{V}$.

A matriz $\mathbf{R}$ indica uma rotação dos eixo principais de um ângulo $\omega$ em torno de uma linha representada por um vetor unitário li, de tal modo que (Oertel, 1996): 


$$
\begin{aligned}
\cos \omega & =\left(R_{11}+R_{22}+R_{33}-1\right) / 2 \\
\mathrm{I}_{1} & =\left(\mathrm{R}_{23}-\mathrm{R}_{32}\right) / 2 \cdot \operatorname{sen} \omega \\
\mathrm{I}_{2} & =\left(\mathrm{R}_{31}-\mathrm{R}_{13}\right) / 2 \cdot \operatorname{sen} \omega \\
\mathrm{I}_{3} & =\left(\mathrm{R}_{12}-\mathrm{R}_{21}\right) / 2 \cdot \operatorname{sen} \omega
\end{aligned}
$$

A vantagem dos tensores $\mathbf{V}$ e $\mathbf{R}$ é que estes constituem também matrizes de transformação (o que não acontece por exemplo com $\mathbf{C}$ ou $\mathbf{c}$ ). Como tais, podem ser multiplicados por outras matrizes de transformação, para a representação de deformações e/ou rotações sucessivas.

Porém o seguinte fato deve ser levado em consideração. Se tivermos dois tensores simétricos de extensão, V1 e V2, porém com orientações distintas dos seus eixos principais, a matriz resultado da sobreposição dos dois

$$
\mathbf{F}=\mathrm{V} \mathbf{2} \cdot \mathbf{V 1}
$$

será no caso geral novamente assimétrica, com uma componente de strain, e uma componente de rotação.

Deve ser notado também que numa matriz simétrica $\mathbf{V}$ representando uma deformação não rotacional, fornecerá um elipsóide de deformação com os eixos principais não obrigatoriamente paralelos ao sistema de referência adotado (o caráter rotacional de uma deformação é indicado pela rotação das linhas que compõem os eixos de deformação, do estado inicial para o final, e não pela orientação dos eixos principais com relação aos eixos do sistema de referência).

Assim, se $\mathbf{V}$ representa uma deformação com eixos principais paralelos ao sistema de referência, a matriz será diagonal:

$$
\mathbf{V}=\left[\begin{array}{ccc}
\mathrm{V}_{1} & 0 & 0 \\
0 & \mathrm{~V}_{2} & 0 \\
0 & 0 & \mathrm{~V}_{3}
\end{array}\right]
$$

onde os componentes $V_{1}, V_{2}, V_{3}$ representam as extensões principais $\left(S_{1}, S_{2}, S_{3}\right)$ do elipsóide de deformação, orientados respectivamente ao longo dos eixos de referência 1, 2, 3 .

Similarmente, pode ser montado o tensor de Cauchy referido para as direções principais de deformação: 


$$
\mathbf{c}=\left[\begin{array}{ccc}
\left(1 / S_{1}\right)^{2} & 0 & 0 \\
0 & \left(1 / S_{2}\right)^{2} & 0 \\
0 & 0 & \left(1 / S_{3}\right)^{2}
\end{array}\right]
$$

A técnica de mudança de sistema de coordenadas para os tensores é mostrada no item 4.14 (capítulo 4).

Todas as equações derivadas da matriz (2.20) serão simplificadas com relação ao caso geral (eq. 2.10).

Por exemplo, a aplicação da equação (2.11) utilizando-se a matriz de (2.20) fornecerá a equação bem conhecida:

$$
\lambda^{\prime}=I^{2} \lambda_{1}^{\prime}+m^{2} \lambda_{2}^{\prime}+n^{2} \lambda_{3}^{\prime}
$$

onde (l, $\mathrm{m}, \mathrm{n})$ são os cossenos diretores de uma linha no estado deformado.

Em duas dimensões, esta se reduzirá ainda a:

$$
\lambda^{\prime}=\cos ^{2}\left(\phi^{\prime}\right) \lambda^{\prime}{ }_{1}+\operatorname{sen}^{2}\left(\phi^{\prime}\right) \lambda^{\prime}
$$

onde $\phi^{\prime}$ é o ângulo que a linha no estado deformado faz com o eixo maior de deformação.

A diferença entre as equações (2.10) e (2.20) refere-se apenas a uma mudança (uma rotação) dos eixos de referência, que teriam a mesma origem, porém orientações distintas. Portanto é uma diferença arbitrária, sem significado físico, já que trata-se apenas de uma escolha de sistema de referência. Os autovalores de c (elongações quadráticas recíprocas principais) serão os mesmos em ambos os casos, e os autovetores (direções principais) serão as mesmas linhas, embora referidas para eixos diferentes.

Já a rotação das equações (2.12), (2.17) e (2.18) é uma rotação real das linhas materiais que compõem os eixos principais de deformação, entre o estado inicial e o final, e como tal tem significado físico.

\subsubsection{Deformação finita heterogênea}

Numa deformação heterogênea, não é possível definir-se uma elipse ou elipsóide de deformação para todo o corpo deformado. Porém, é possível dividir-se o corpo em porções suficientemente pequenas, tendendo a zero, de tal modo que em cada parte do corpo deformado pode-se definir uma elipse ou elipsóide de deformação. Numa deformação heterogênea, as 
elipses de deformação variam de ponto a ponto em termos da orientação de seus eixos e de suas razões axiais.

$\mathrm{Na}$ deformação heterogênea, as equações de transformação de coordenadas são funções não lineares.

Para analisar-se a variação da mudança de posição dos pontos materiais, define-se um tensor de gradiente de deformação, equivalente às derivadas parciais de $\mathbf{x}$ com relação a $\mathbf{X}$ :

$$
\begin{gathered}
d \mathbf{X}=\mathbf{F} \cdot \mathbf{d} \mathbf{X} \\
\mathbf{F}=\frac{d \mathbf{x}}{d \mathbf{X}} \\
F_{i j}=\left[\frac{\partial x_{i}}{\partial X_{j}}\right]=\left[\begin{array}{lll}
\frac{\partial x_{1}}{\partial x_{1}} & \frac{\partial x_{1}}{\partial x_{2}} & \frac{\partial x_{1}}{\partial x_{3}} \\
\frac{\partial x_{2}}{\partial x_{1}} & \frac{\partial x_{2}}{\partial x_{2}} & \frac{\partial x_{2}}{\partial x_{3}} \\
\frac{\partial x_{3}}{\partial x_{1}} & \frac{\partial x_{3}}{\partial x_{2}} & \frac{\partial x_{3}}{\partial x_{3}}
\end{array}\right]
\end{gathered}
$$

Outra forma de definição dessa matriz é dizer que ela representa o gradiente do campo dos vetores $\mathbf{x}_{i}$ na posição deformada, com relação à posição indeformada (Notar que, se o gradiente de um campo escalar é um vetor, o gradiente de um campo vetorial é um tensor de $2^{\mathrm{a}}$ ordem, representado por uma matriz $3 \times 3$ ).

Notar ainda que, no caso específico de deformação homogênea, as equações de transformação são lineares, e as derivadas parciais correspondem aos coeficientes das equações. Por exemplo:

$$
x_{1}=a X_{1}+b X_{2}+c X_{3}
$$

portanto

$$
\frac{\partial x_{1}}{\partial X_{1}}=a X_{1}^{0}+0+0=a, \text { etc }
$$

Assim, para a deformação homogênea, a matriz $\mathbf{F}$ representa tanto a matriz de transformação de coordenadas como a matriz (tensor) gradiente de deformação.

No caso de deformação heterogênea, além da condição necessária de que o volume de um elemento qualquer não se torne zero ou a infinito $(\infty>\operatorname{det}[\mathbf{F}]>0)$, também é necessário estabelecer-se as condições de compatibilidade, ou seja, durante a deformação uma porção da 
matéria não pode se sobrepor a outra, nem dar lugar a espaços vazios. Essa condição é assegurada por um conjunto de equações diferenciais, denominadas equações de compatibilidade de strain. Asseguram que a deformação varia continuamente através de todo o campo.

As descontinuidades nesta teoria têm que serem consideradas como condições de borda do corpo deformado. Por exemplo, uma falha limitando um bloco deformado ductilmente. 


\subsection{Modelos cinemáticos e dinâmicos de zonas de cisalhamento}

\subsubsection{Introdução}

Zonas ou cinturões de cisalhamento foram definidos originalmente como zonas tabulares de deformação intensa, em comparação com os blocos adjacentes. Ramsay \& Graham (1970) estabeleceram o modelo cinemático clássico. Ramsay (1980) publicou uma revisão sobre o tema, apresentada em Simpósio realizado em Barcelona sobre os mesmo assunto e que espelhava o sucesso que o conceito alcançou nessa primeira década.

Outra corrente de pesquisadores adotou o modelo associado ao conceito de transpressão (Harland, 1971, Sanderson \& Marchini, 1984). Neste modelo assume-se a ocorrência de cisalhamento puro perpendicular às paredes da zona de cisalhamento, além de cisalhamento simples paralelo a elas. Grande número de trabalhos foram publicados na década de 90 baseados nesta linha de modelagem.

\subsubsection{O modelo de Ramsay \& Graham}

Os pressupostos básicos deste modelo são, primeiro, que as deformações das rochas são comumente heterogêneas, isto é, o estado de strain e a rotação variam de um ponto a outro através de uma região deformada ductilmente. Em segundo lugar, que as rochas submetidas à deformação dúctil comportam-se como um continuum de partículas, ou seja, como um conjunto interconectado de partículas ou partes menores, cuja deformação não pode levar à sobreposição, nem à ocorrência de buracos vazios. Este segundo pressuposto leva ao conceito de compatibilidade de strain, ou seja, que nem todos estados de strain são geometricamente possíveis através de um corpo deformado heterogeneamente, mas somente aqueles que não levem ao rompimento do meio contínuo. Estas condições são estabelecidas pelas equações de compatibilidade de strain (Truesdell e Toupin, 1960, Malvern, 1969, Jaeger, 1969).

As condições de contorno utilizadas foram de que a zona de deformação fosse planar (paredes paralelas); eixos cartesianos $(x, y, z)$ de referência tomados tais que y seja perpendicular às paredes da zona de cisalhamento; que em qualquer plano paralelo a xz a intensidade e orientação da deformação sejam iguais ao longo desse plano ou, dito de outra forma, os parâmetros da deformação em cada ponto da zona de cisalhamento sejam funções apenas de y.

A matriz de deformação seria a seguinte:

$$
\mathrm{F}:=\left[\begin{array}{ccc}
1 & \gamma(\mathrm{y}) & 0 \\
0 & \mathrm{~S}(\mathrm{y}) & 0 \\
0 & 0 & 1
\end{array}\right]
$$


onde $\gamma(y)$ é o cisalhamento heterogêneo horizontal ao longo de $x$, em função da posição em y, e $\mathrm{S}(\mathrm{y})$ é o achatamento uniaxial na direção y, em função da posição em y. A variação volumétrica associada a essa deformação é o determinante da matriz que, no caso, será o próprio valor de $S$ (extensão na direção y):

$$
\mathrm{S}=\operatorname{det} \mathbf{F}=\frac{\mathrm{V}_{\mathrm{F}}}{\mathrm{V}_{\mathrm{I}}}
$$

Em conseqüência, apenas os seguintes campos de deformação seriam possíveis: (1) cisalhamento simples heterogêneo na direção x; (2) variação de volume na direção y (ou, dito de outro modo, achatamento ou estiramento uniaxial ao longo da direção y); e (3) combinações de (1) e (2). Seria possível ainda a sobreposição de deformação homogênea afetando igualmente a zona de cisalhamento e os blocos adjacentes.

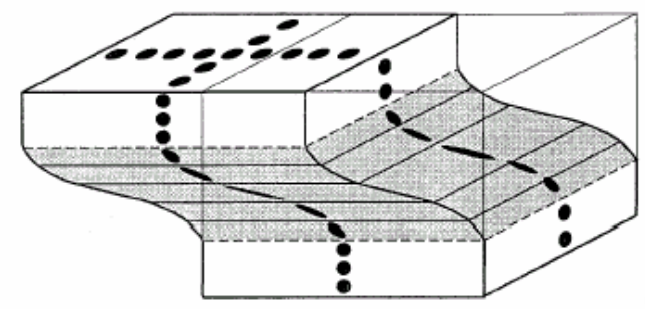

a
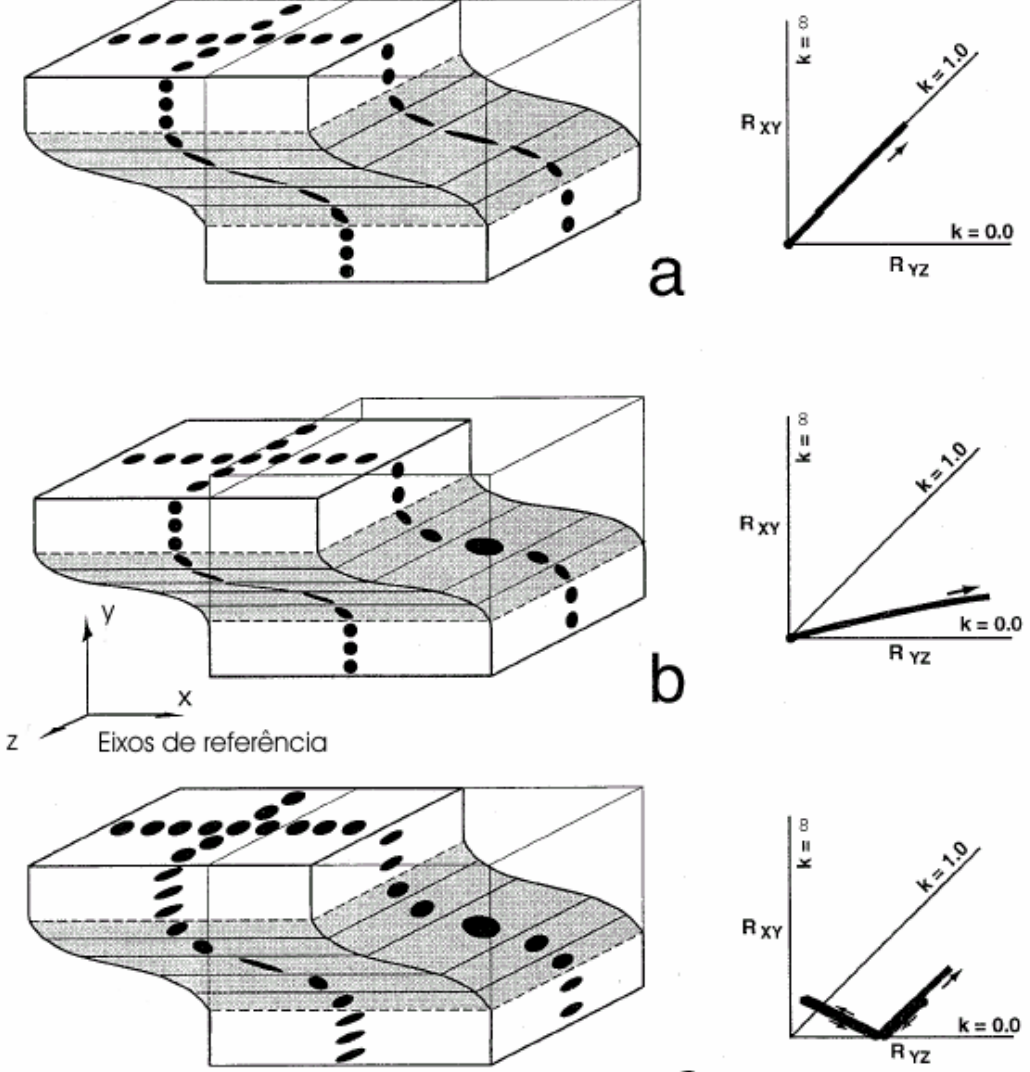

C

Figura 2.3 - Campos de deformação possíveis para zonas de cisalhamento tabulares segundo o modelo de Ramsay \& Graham (1970) a) desenvolvidas por cisalhamento simples heterogêneo segundo a direção paralela às paredes; b) mesmo caso que (a) acrescido de achatamento uniaxial ("perda de volume") perpendicular às paredes c) mesmo caso que (b), acrescido de deformação homogênea qualquer sobrepostas tanto à zona de cisalhamento como aos blocos adjacentes. No lado direito, diagramas de Flinn mostrando o caminho do strain (modificado de Hudleston, 1999). 
As conseqüências em termos dos padrões de deformação para o modelo de zonas de cisalhamento desenvolvidas unicamente por cisalhamento simples seriam: 1) a deformação seria plana, com o eixo intermediário do elipsóide de deformação com extensão $S_{2}=1, K=1$ e a volume constante; 2) a direção do plano de máximo achatamento (XY) e a direção de maior estiramento (X) iniciar-se-iam a $45^{\circ} \mathrm{com}$ a direção de cisalhamento, e progressivamente rotacionariam para ela, produzindo os padrões sigmóides de foliação, que receberam a denominação de estruturas S/C; no entanto, o ângulo entre a foliação e a direção de cisalhamento nunca chegaria a zero; 3) as estruturas lineares pré-existentes sofrem rotação em direção ao eixo $X$ do elipsóide de deformação, e as estruturas planares em direção ao plano $\mathrm{XY}$; deste modo, as estruturas préexistentes também seriam deflexionadas em um padrão semelhante a "S/C", 4) todos os parâmetros da deformação $\left(S_{1}, S_{3}, \Delta \mathrm{V}, \theta . \theta^{\prime}, \omega\right.$ etc.) são especificados em função da deformação cisalhante $\gamma$ em cada ponto, que por sua vez é função apenas de $y$, ou seja, da distância perpendicular às paredes; o deslocamento total pode ser calculado pela integralização do cisalhamento versus y; 5) os eixos de deformação incremental (infinitesimal) são orientados a $45^{\circ}$ e $135^{\circ}$ com a zona de cisalhamento, são paralelos aos eixos de velocidade da deformação e, em um material mecanicamente isótropo, paralelos aos eixos principais de tensão e alguma função de seus valores principais; 6 ) o eixo de vorticidade (velocidade de rotação) seria perpendicular à zona de cisalhamento, paralelo a $\mathbf{Y}$, ou seja, perpendicular ao plano $\mathbf{X Z}$, e os indicadores cinemáticos deveriam ser observados nesse plano.

Já admitindo-se um achatamento uniaxial em y, os elipsóides tenderiam a oblatos $(K<1)$, com perda de volume, e o plano de máximo achatamento poderia iniciar em ângulos menores do que $45^{\circ} \mathrm{com}$ a zona de cisalhamento.

\subsubsection{Os modelos transpressivos}

Transpressão foi um termo cunhado originalmente por Harland (1971), aplicando-se à deformação de uma zona planar submetida simultaneamente a compressão e transcorrência. Transtensão foi o termo logicamente simétrico criado a seguir, indicando extensão e transcorrência simultâneas.

O termo transpressão tem diferentes significados na literatura geológica. Seguindo Robin \& Cruden (1994), pode-se dizer que existem dois modos em que transpressâo pode ser entendida.

Um sentido mais geral, que se pode chamar de "tectônico", no qual transpressão refere-se aos processos de deformação ocorrentes com a convergência oblíqua de duas placas ou terrenos tectônicos. Esta convergência oblíqua poderia ser acomodada, por exemplo, com a partição da deformação em transcorrências paralelas às bordas da zona de convergência, e em empurrões em sentido perpendicular a ela (e.g., Richard \& Cobbold, 1990). 
Outro sentido, mais restrito, que se pode chamar de "estrutural", inaugurado por Sanderson \& Marchini (1984), refere-se à modelagem matemática de uma zona de deformação tabular, freqüentemente tomada como vertical, com suas paredes sendo simultaneamente aproximadas (achatando a zona de deformação) e deslocadas lateralmente (cisalhadas). Se a zona de cisalhamento for confinada lateralmente e na sua base, surge um problema de espaço, que só pode ser resolvido por perda de volume (o que reduziria ao modelo de Ramsay \& Graham) ou por extrusão vertical de material ao longo da zona.

Pode-se ainda adicionar um terceiro sentido, mais particular e localizado, desenvolvido inicialmente no estudo das zonas de cisalhamento mais superficiais (e.g. Sylvester \& Smith, 1976) onde zonas alternadamente compressivas ou distensivas poderiam ser geradas ao longo de cinturões de cisalhamento transcorrentes, conforme 0 sentido de suas curvaturas, escalonamentos ou terminações. Situações particulares também ocorreriam nas junções e terminações de zonas de cisalhamento.

A modelagem matemática, em geral tida como originalmente proposta por Sanderson \& Marchini (1984), mas já apresentada por Coward (1976) e Sanderson (1982), embora não sob a denominação de "transpressão", adotada e desenvolvida posteriormente por diversos autores, prescreve a ocorrência de cisalhamento simples (CS) e cisalhamento puro (CP), o que pode ser modelado pela multiplicação de suas respectivas matrizes de deformação:

$$
\begin{gathered}
\mathrm{CS}:=\left[\begin{array}{lll}
1 & \gamma & 0 \\
0 & 1 & 0 \\
0 & 0 & 1
\end{array}\right] \quad \mathrm{CP}:=\left[\begin{array}{ccc}
1 & 0 & 0 \\
0 & \alpha^{-1} & 0 \\
0 & 0 & \alpha
\end{array}\right] \\
\mathrm{T}=\mathrm{CS} . \mathrm{CP} \\
\mathrm{T}:=\left[\begin{array}{ccc}
1 & \alpha^{-1} \cdot \gamma & 0 \\
0 & \alpha^{-1} & 0 \\
0 & 0 & \alpha
\end{array}\right]
\end{gathered}
$$

As condições de contorno do modelo original prescrevem deformação homogênea, superfície superior livre, paredes delimitadas por descontinuidades (falhas), superfície inferior fixada e ausência de variação de volume. 


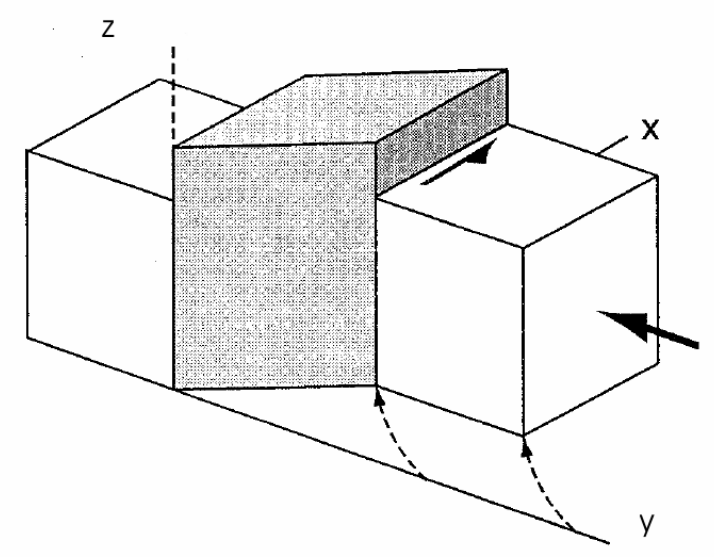

Figura 2.4 - Transpressão, segundo Sanderson \& Marchini (modificado de Hudleston, 1999)

As conseqüências do modelo são que as deformações na transpressão produzem strains oblatos (pizzas, com $\mathrm{K}<1$ ), a volume constante, com foliações (plano $X Y$ do elipsóide de deformação finita) verticais e a um ângulo com as paredes menor do que $45^{\circ}$. Já as lineações de estiramento (eixo $X$ do elipsóide de deformação finita) poderiam ser horizontais (no caso de domínio da transcorrência) ou verticais (no caso de domínio do cisalhamento puro), mas não oblíquas.

A questão das lineações pode ser compreendida da seguinte maneira. Considere-se inicialmente uma "transpressão" com transcorrência "pura" $(\alpha=1)$; o eixo X é horizontal e $\mathrm{K}=1$. Justapondo-se um cisalhamento puro (com $S_{1}$ vertical e $S_{3}$ horizontal perpendicular às paredes da zona), com valores de $\alpha$ progressivamente maiores, o elipsóide vai se tornando oblato $(K<1)$, até virar uma "pizza" perfeita ( $K=0)$, quando então a lineação desvanece (torna-se um tectonito $S$ ). Prosseguindo como aumento de $\alpha, S_{1}$ torna-se vertical, e $\mathrm{K}$ torna a aumentar.

Outra conseqüência interessante do modelo é que o eixo de vorticidade permanece vertical, seja a lineação horizontal ou vertical, e portanto os indicadores cinemáticos deveriam ser observados sempre no plano horizontal ( $X Z$ ou YZ do elipsóide de deformação, conforme o caso).

No caso da transtensão $(\alpha<1)$, a lineação é sempre horizontal. Porém, em determinado ponto a foliação passa de empinada a horizontal, conforme se passa de um regime dominado pela transcorrência para um dominado pelo cisalhamento puro. Notar que nesse ponto intermediário a foliação deveria desvanecer, com um elipsóide do tipo charuto (tectonito $L$, com $K=\infty$ ). A figura abaixo mostra essas relações em função de $\alpha$ e da razão de strain $\left(R_{s}\right)$. 


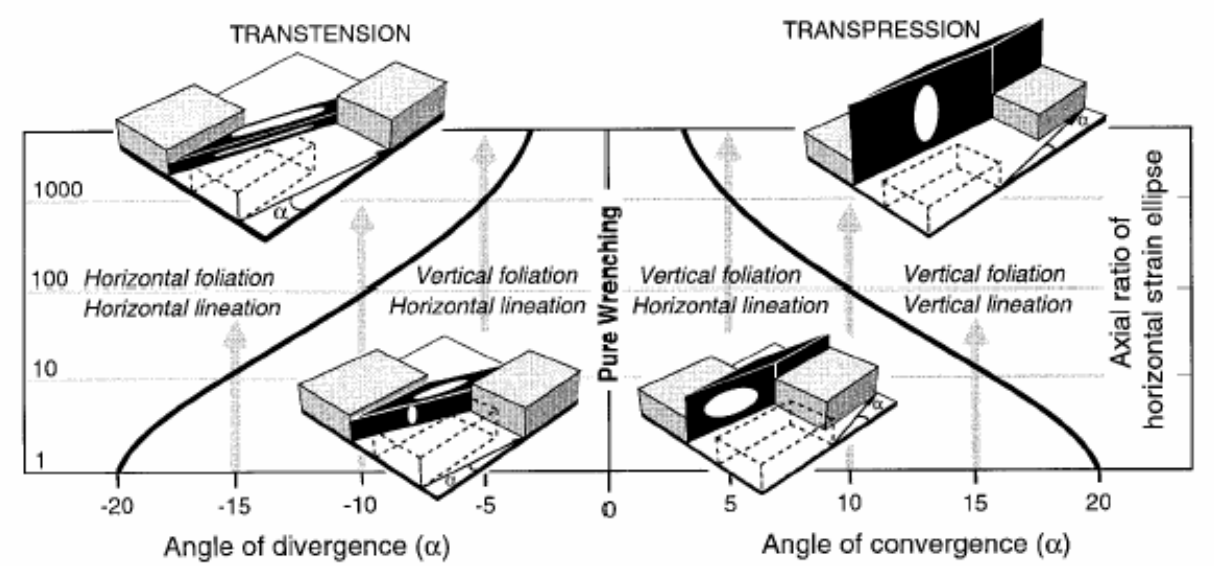

Figura 2.5 - Diagrama com o ângulo de convergência / divergência plotado contra a razão axial da elipse de deformação horizontal, mostrando as orientações da foliação e lineação esperados nos vários campos de transpressão e transtração (Teyssier \& Tikoff, 1999).

Este modelo vem sendo aperfeiçoado e modificado por diversos autores. Assim passou-se a modelar utilizando-se os tensores de deformação incremental (infinitesimal) e de velocidade de deformação, de modo a considerar-se os efeitos da deformação progressiva sobre os fabrics e os estados de deformação finita; extrusões laterais e oblíquas, fluxos não estáveis (non steady), etc. (e.g. Fossen \& Tikoff, 1993, 1997, 1994, Tikoff \& Fossen, 1993, Tikoff \& Teyssier, 1994, Tessier \& Tikoff, 1999, Jiang \& Williams, 1998, Dias \& Ribeiro, 1994).

O modelo no entanto tem recebido duas críticas básicas.

Um a primeira refere-se à questão da compatibilidade de strain. A proposição de um componente de cisalhamento puro, sem a prescrição de um componente de rotação associada, não permite a ocorrência de deformação heterogênea, sem violar a questão da compatibilidade de strain (Ramsay \& Huber,1987, Hudleston, 1999). Considerando a zona de transpressão como uma célula de deformação homogênea, este problema limita-se aos contatos da zona de deformação com as paredes dos blocos adjacentes, onde deve ocorrer um descontinuidade e deslizamento ao seu longo.

Outra crítica, de certa forma relacionada à primeira, é de que os movimentos seriam totalmente livres e sem atrito ao longo das paredes na direção vertical, permitindo a extrusão vertical do material, mas são absolutamente impedidos ao longo das mesmas paredes na direção horizontal, permitindo a transmissão do esforço cisalhante. Uma analogia mecânica seria de que as paredes comportam-se como tendo caneluras verticais, permitindo o movimento nessa direção, mas bloqueando-o na horizontal. Porém tal situação não parece ser geologicamente plausível.

Robin \& Cruden(1994) e Dutton (1997) procuraram resolver a questão da compatibilidade de strain nas zonas transpressivas adotando a modelagem clássica de um fluido espremido entre duas placas rígidas e paralelas que se aproximam entre si (e.g. Jaeger, 1969) sobreposta por um componente de cisalhamento simples homogêneo paralelo às paredes. 


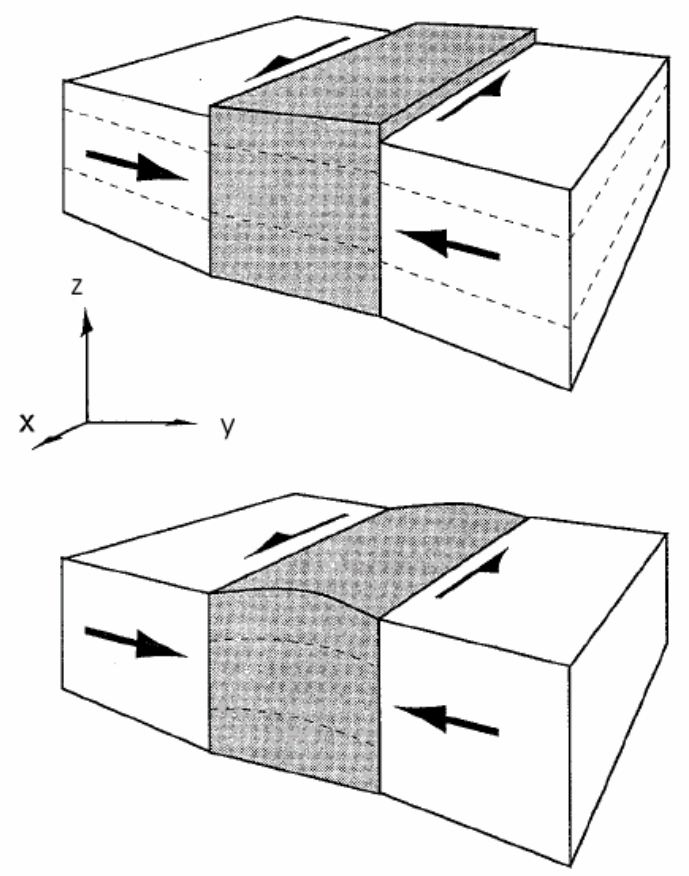

Figura 2.6 - No bloco superior, transpressão mostrando as descontinuidades com a parede, segundo o modelo de Sanderson \& Marchini (1984), e no bloco abaixo, com compatibilidade de strain com as paredes, segundo o modelo de Robin \& Cruden (1994) (modificado de Hudleston, 1999).

Possíveis campos de distribuição de foliação (suposta paralela ao plano XY do elipsóide de deformação finita) e de lineação (suposta paralela ao eixo $X$ do elipsóide de deformação finita) são mostrados na figura abaixo. Estes porém não parecem corresponder aos padrões em leque abertos para cima ("flores positivas") em geral observados e interpretados como devidos à "transpressão".
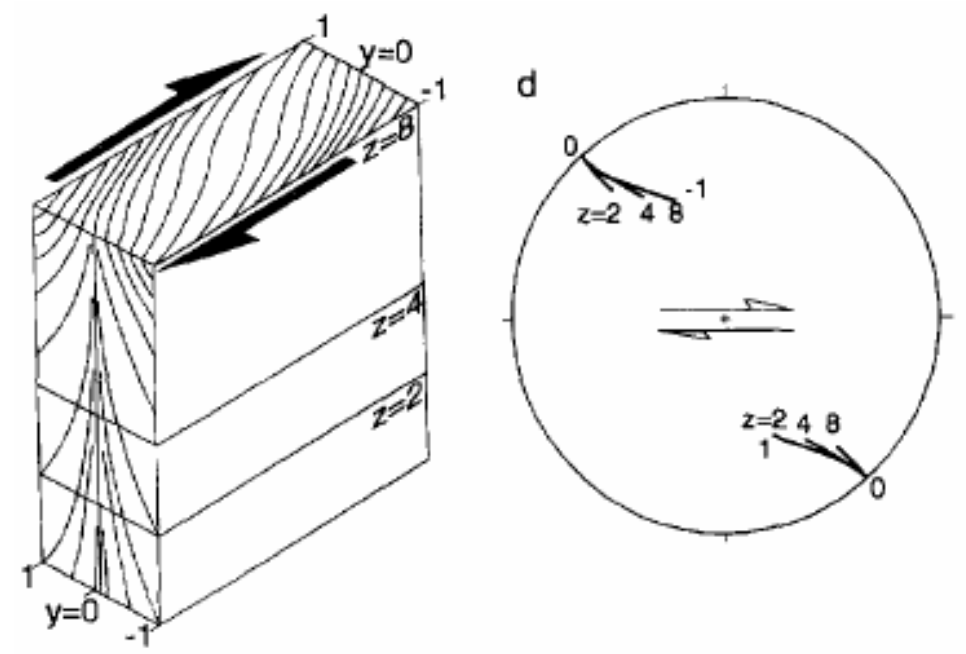

Figura 2.7 - Exemplo de distribuição da foliação prevista no modelo de transpressão de Robin \& Cruden (1994). 


\subsubsection{Empurrões seguidos de transcorrência}

Outro modelo interessante proposto na literatura é o de Merle \& Gapais (1997), no qual montam uma equação matricial que combina cisalhamento simples transcorrente e cisalhamento simples de empurrão (ou normal, invertendo o sentido do movimento), fixando a transcorrência como vertical em $\mathrm{x}$, e variando a direção e o mergulho do empurrão através de matrizes de rotação, como se segue.

Transcorrência (Wrench) E/W

$$
\mathrm{W}:=\left[\begin{array}{ccc}
1 & \gamma \mathrm{w} & 0 \\
0 & 1 & 0 \\
0 & 0 & 1
\end{array}\right]
$$

giro da direção do empurrão

$$
\mathrm{R} \alpha:=\left[\begin{array}{ccc}
\cos (\alpha) & -\sin (\alpha) & 0 \\
\sin (\alpha) & \cos (\alpha) & 0 \\
0 & 0 & 1
\end{array}\right]
$$

$$
\mathrm{WT}:=\mathrm{R} \alpha \cdot \mathrm{R} \theta \cdot \mathrm{T} \cdot \mathrm{R} \theta^{-1} \cdot \mathrm{R} \alpha^{-1} \cdot \mathrm{W}
$$

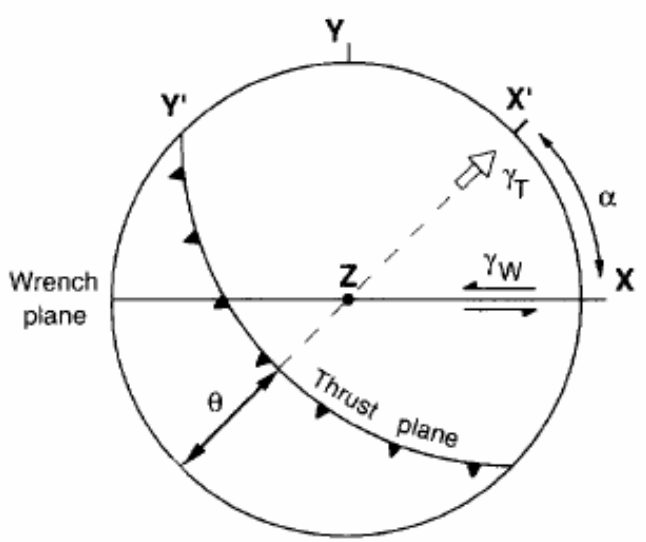

Figura 2.8 - Hemisfério inferior do estereograma mostrando os parâmetros do modelo de Merle \& Gapais (1997).

Através deste modelo também são obtidos elipsóides oblatos quando se prescreve empurrões, e prolatos quando se prescreve movimentos normais. As atitudes possíveis da foliação e lineação obtidas são no entanto mais variadas, podendo ser obtidos vários casos oblíquos intermediários entre transcorrência e empurrões "puros". Por exemplo podem ser modeladas deformações oblatas com alto ângulo com relação à transcorrência e com lineações oblíquas. Atende às prescrições de compatibilidade de strain; porém podem ser obtidos eixos de 
rotação oblíquos às seções principais do elipsóide de deformação, implicando em simetrias triclínicas. Pode ser uma abordagem mais realista para muitas faixas de convergência oblíqua, onde se tem empurrões seguidos e em parte acompanhados de transcorrência.

\subsubsection{Ainda sobre a questão dos elipsóides oblatos em zonas de cisalhamento}

Os modelos transpressivos tem se tornado populares entre outros motivos por fornecerem uma explicação para a ocorrência de elipsóides de deformação oblatos em zonas de cisalhamento. Deve ser lembrado no entanto que o modelo básico constitui-se numa fatoração matricial; e diversos outros esquemas de fatoração podem ser feitos para produzir resultados semelhantes.

Dentro do modelo mais geral de Ramsay \& Graham (1970), quando se prescreve a componente de achatamento uniaxial perpendicular às paredes, obtém-se também elipsóides oblatos $(K<1)$ e atitudes iniciais da foliação a ângulos menores que $45^{\circ}$. Quanto maior a razão entre o achatamento uniaxial e o cisalhamento simples prescritos, mais oblatos serão os elipsóides e mais tendente a paralela com as paredes será a foliação. No entanto neste caso haverá perda de volume (na direção perpendicular às paredes) e as lineações (eixo $\mathbf{X}$ de deformação), embora podendo desvanecer em um caso extremo de achatamento, nunca inverteriam para verticais. Por outro lado, como o cisalhamento simples e o achatamento uniaxial são deformações que atendem às equações de compatibilidade de strain, são possíveis deformações dúcteis heterogêneas através da zona de cisalhamento, sem a necessidade de discontinuidades.

Também no modelo de Ramsay \& Graham (op. cit.) é possível prescrever-se deformações homogêneas quaisquer, incluindo aí o cisalhamento puro, desde que afetem tanto os blocos adjacentes como a zona de cisalhamento. Neste caso, combinações complexas e variadas de deformação homogênea, cisalhamento simples heterogêneo e achatamento uniaxial heterogêneo são possíveis.

\subsubsection{Modelagem física e a partição da deformação em zonas de convergência oblíqua}

Outra linha desenvolvida por alguns pesquisadores na última década foi a da modelagem analógica da convergência oblíqua, isto é, a modelagem física em modelos reduzidos com materiais de comportamento análogo às rochas, considerando as necessárias conversões de escala de tempo, dimensões, velocidade de deformação e parâmetros reológicos.

A modelagem clássica para zonas puramente transcorrentes foi realizada no começo do século 20 por Riedel (apud Tchalenko, 1970) resultando no modelo bastante conhecido como "fraturas de Riedel". Outras simulações interessantes de transcorrência "pura" são as apresentadas por Richard, Mocquet e Cobbold(1991). Este último modelo simula uma cobertura 
sedimentar sobre um embasamento rígido, produzindo dobramentos na cobertura com planos axiais empinados e eixos horizontais, com um padrão escalonado de charneiras em planta.

Simulações de sistemas transpressivos foram realizadas por Richard e Cobbold (1990), Schreurs e Colletta (1998) e Casas et al. (2001). Basicamente monta-se aparatos que permitem uma convergência de dois anteparos acompanhada de um deslocamento lateral (cisalhamento). Nota-se nestes ensaios que a deformação não se distribui homogeneamente, mas sofre uma partição física, concentrando-se em falhas direcionais e de empurrão, mostrando em perfil padrões semelhantes às estruturas em flor positiva. A predominância de transcorrências, empurrões ou falhas oblíquas, bem com a seqüência temporal de seu aparecimento, dependem do ângulo de convergência, que implica nas taxas relativas de convergência e transcorrência, e do valor da deformação total imposta.

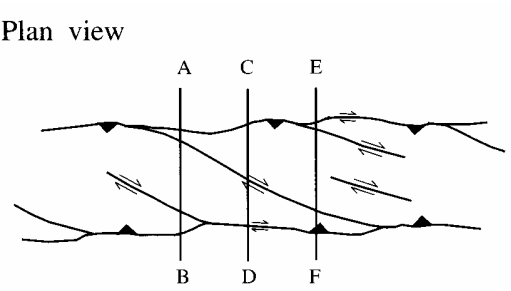

a. dextral transpression

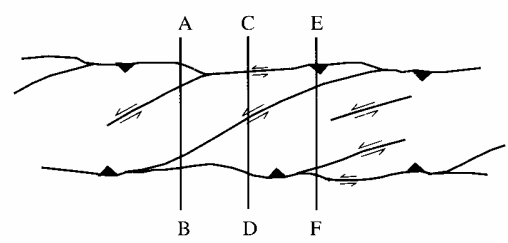

b. sinistral transpression
Vertical sections
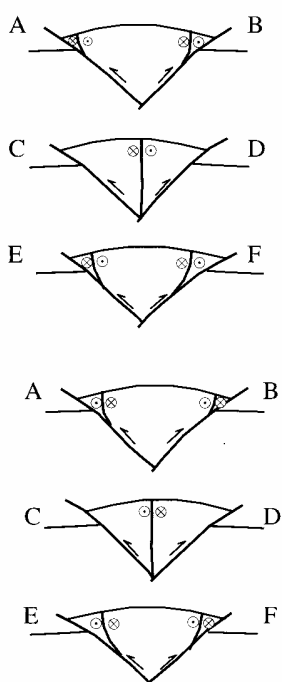

Figura 2.9 - Padrões de coalescência de falhas direcionais e oblíquas com pop-up, a partir de experimentos analógicos (Schreurs \& Colleta, 1998)

\subsubsection{O comportamento mecânico dos materiais - Em busca de um novo modelo}

As modelagens clássicas de zonas de cisalhamento (Ramsay e Graham, 1970, Ramsay, 1980) e de transpressão (Sanderson e Marchini, 1984) são puramente cinemáticas, isto é, modelam apenas as variações de strain e de rotação, ou, dito de outra forma, as variações da geometria dos objetos submetidos à deformação. Não consideram a reologia dos materiais, ou seja seu comportamento deformacional frente à aplicação de diferentes sistemas de esforços (tensões).

O modelo de Robin e Cruden prevê um material comportando-se como um fluido newtoniano. A velocidade de deformação é proporcional ao esforço aplicado, sendo a constante 
de proporcionalidade a viscosidade, e o fluido não apresenta resistência ao cisalhamento, isto é, flui sob qualquer valor de esforço aplicado.

Já Talbot (1999) apresenta uma interessante modelagem de zonas de cisalhamento simples pressupondo fluidos que obedecem a leis exponenciais, isto é, a relação entre o strain e o esforço é uma função exponencial (power law) e não mais linear. É possível aproximar-se bastante de vários casos naturais, com, por exemplo, ângulos muito baixos entre a "foliação" gerada e a zona de cisalhamento, bem como deformações muito concentradas em seu centro.

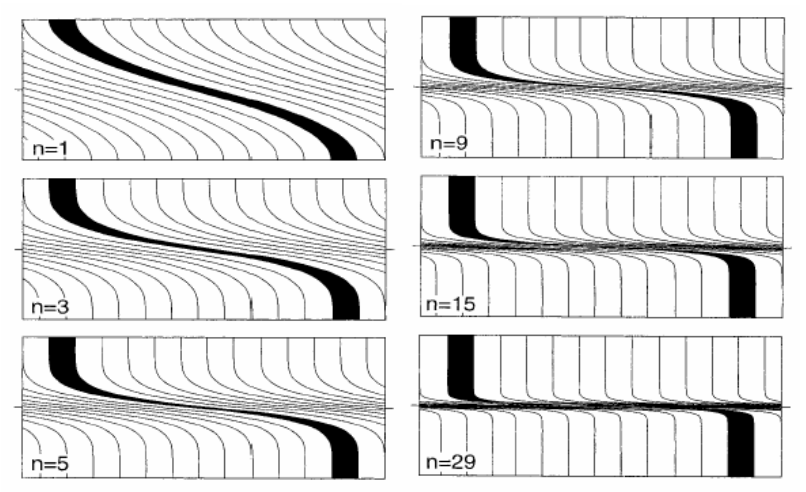

Figura 2.10 - Modelos de desenvolvimento de zonas de cisalhamento considerando fluidos que obedecem a uma relação exponencial entre o esforço e a velocidade de deformação, sendo $n$ o expoente (Talbot, 1999).

Já os modelos de ruptura de materiais, bem como os de comportamento plástico, prevêem que os materiais têm um limite de resistência, ou seja, deformam-se por ruptura ou por fluxo plástico a partir de um certo valor de esforço cisalhante aplicado, e não abaixo dele.

As condições que determinam a partir de qual valor de esforço a deformação ocorre, expressas por equações e seus parâmetros, são denominadas critérios de resistência. Para a deformação plástica o mais conhecido é o de Von Mises, o qual estabelece uma relação que depende dos invariantes do tensor de esforços. Para a deformação por ruptura, o mais simples e conhecido é o Mohr - Coloumb, o qual estabelece uma relação linear entre o esforço cisalhante que provoca ruptura sobre um determinado plano, e o esforço normal aplicado sobre esse mesmo plano, tendo como parâmetros a coesão e o coeficiente de atrito do material.

Dado um sistema de esforços triaxial $\left(\sigma_{1}>\sigma_{2}>\sigma_{3}\right)$, os valores de esforço cisalhante máximo conformam-se a dois planos perpendiculares entre si, tendo $\sigma_{1}$ e $\sigma_{3}$ em suas bissetrizes (a $45^{\circ}$ de cada plano), e $\sigma_{2}$ em sua interseção.

No comportamento plástico, a deformação iniciar-se-á por planos e com essas orientações e neles concentrar-se-á. Serão os sítios preferenciais para a localização de strain e rotação, já é que neles alcança-se em primeiro lugar o limite de resistência à plasticidade, desde que o material seja homogêneo e isótropo em termos reológicos. É o que ocorre por exemplo com ensaios de deformação de parafina, argila úmida e metais. Em diversos experimentos ocorrem planos de deslizamento, os quais se conformam a esses planos de máximo cisalhamento. Odé (1960) 
propõe as falhas dúcteis, sugerindo que em diversos materiais naturais e experimentos o critério de plasticidade pode explicar melhor as feições observadas do que os critérios de ruptura.

O critério de ruptura de Mohr - Coloumb vale essencialmente para o campo de esforços compressivos, e prevê que a ruptura por cisalhamento não ocorrerá obrigatoriamente e em geral nas direções de esforço cisalhante máximo, mas sim a ângulos menores com $\sigma_{1}$, já que o limite de resistência à ruptura por esse critério depende também do coeficiente de atrito $\mu$ do material multiplicado pelo esforço normal $\sigma_{\mathrm{n}}$ atuante sobre o plano dado mais a coesão interna $\mathrm{c}_{0}$ :

$$
\tau_{\mathrm{R}}=\mathrm{C}_{0}+\mu . \sigma_{\mathrm{n}}
$$

Para grande parte das rochas e materiais como concreto, em condições ambientes de T e $P$ na superfície terrestre, este critério estabelece uma boa aproximação. $E$ para ângulos de atrito médios para esses materiais em torno de $30^{\circ}$, estabelece planos de ruptura a cerca de $30^{\circ} \mathrm{com}$ $\sigma_{1}$ e $60^{\circ} \mathrm{com} \sigma_{3}$. O limite de ruptura por esse critério depende também da pressâo confinante $(=$ esforço médio), sendo progressivamente maior para pressões confinantes maiores.

Quando se passa para condições de esforços distensivos, esse critério progressivamente perde a validade, sendo necessários valores em módulo de esforços bastante menores para atingir-se o valor de resistência à ruptura por extensão. O critério de Griffith, o qual estabelece uma forma de parábola deitada para a envoltória de ruptura no diagrama de Mohr, adequa-se mais aos experimentos observados. Esse mesmo critério, para o campo de esforços compressivos e pressões confinantes progressivamente maiores, prevê uma diminuição da declividade (do "ângulo de atrito") da envoltória de ruptura.

Notar que para materiais dúcteis, com coeficiente de atrito tendendo a zero, tais como metais, argila úmida e provavelmente rochas sob temperaturas maiores, a envoltória de Mohr Coloumb torna-se igual à do critério de plasticidade de Von Misis (Odé, 1960, Ramsay, 1967), estabelecendo em um diagrama de Mohr duas retas paralelas ao eixo das abcissas, prevendo que se alcance o limite de resistência em dois planos perpendiculares entre si, a $45^{\circ} \operatorname{com} \sigma_{1}$ ou $\sigma_{3}$, e sem dependência da pressão confinante. 
(a)

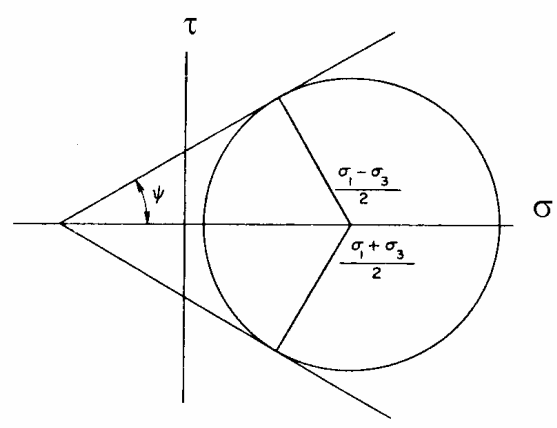

(b)

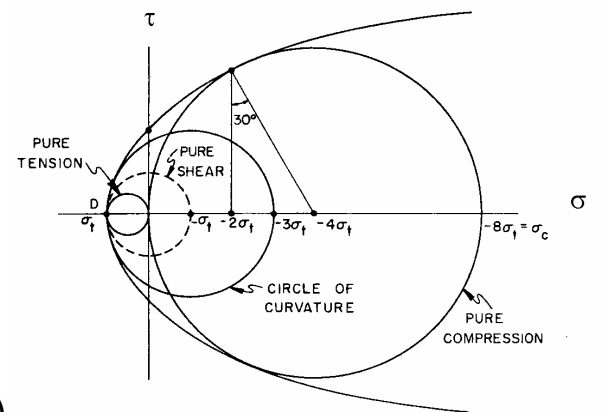

(c)

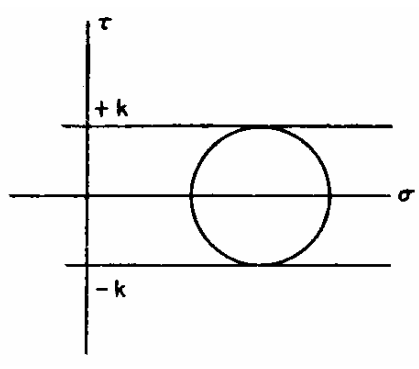

Figura 2.11 - Diagramas de Mohr com envoltórias de resistência ilustrando em (a) o critério de ruptura de Mohr-Coulomb, em (b) o critério de ruptura de Griffth, e em (c) o critério de plasticidade de Von Misis para deformação plana (a partir de Odé, 1960)

A consideração da existência de limites de resistência nos materiais, tanto no comportamento plástico como no rúptil, produz uma explicação para o fenômeno de partição da deformação, mesmo quando consideramos materiais homogêneos e isótropos. Uma massa de rochas submetida a esforços diferenciais $\left(\sigma_{1} \neq \sigma_{2} \neq \sigma_{3}\right)$ não deverá se comportar homogeneamente, mas desenvolverá falhas ou zonas de cisalhamento com orientação e sentido de rotação adequados com relação às direções principais de esforços. A deformação tenderá a ser heterogênea e localizada nessas zonas.

Anderson (1951), baseado nos critérios de ruptura, e na premissa de que próximo à superfície da Terra, os esforços principais têm que ser perpendiculares ou paralelos à superfície (como a superfície da Terra é livre, tem que ser um plano com cisalhamento nulo), propôs a clássica divisão tripartida das falhas (transcorrentes, inversas e normais), com suas atitudes típicas. Baseando-se nestas considerações as atitudes oblíquas de falhas devem ser mais raras, e associadas a existência de anisotropias e/ou sobreposição de eventos.

\subsubsection{Sobre a questão do ângulo entre conjugados}

O modelo de ruptura pelo critério de Mohr-Coloumb, para os valores usuais do coeficiente de atrito de rochas em condições superficiais prevê a ocorrência de fraturas conjugadas de cisalhamento (falhas portanto) a um ângulo de cerca de $60^{\circ}$ entre si, com movimentos opostos e com $\sigma_{1}$ na bissetriz do diedro agudo. Explica bem o padrão de fraturas obtido no experimento de 
Riedel, com R e R' correspondendo às fraturas conjugadas, $T$ às fraturas de extensão paralelas a $\sigma_{1}$, e a direção geral de cisalhamento a $45^{\circ}$ com $\sigma_{1}$.

Em ambientes dúcteis nota-se que o ângulo diedro entre os conjugados de cisalhamento tende a aumentar, podendo nos casos extremos a direção de máxima compressão estar na bissetriz do ângulo obtuso (Ramsay, 1980).

Para materiais totalmente dúcteis, com coeficiente de atrito nulo, ou que atendem ao critério de plasticidade (metais, argila úmida, rochas em alta temperatura), o ângulo diedro entre os conjugados de cisalhamento como visto acima deveria ser $90^{\circ}$. Ângulos obtusos na direção de máxima compressão poderiam ser obtidos por achatamento homogêneo e rotação do sistema de conjugados já formado.

\subsubsection{Sobre a obliqüidade de lineações}

Em estruturas de flor transpressivas dúcteis, os empurrões externos ("pétalas") podem mostrar lineações oblíquas. Usando a analogia do rejeito em falhas oblíquas, poder-se-ia pensar em componentes direcionais e de mergulho das lineações, com movimentos correspondentes. $O$ raciocínio mais imediato seria da necessidade da coerência desses componentes com o regime geral da deformação. Numa "transpressão", com componente transcorrente destral, imaginar-se-ia que a componente direcional nas falhas oblíquas das pétalas também deveria ser destral.

Porém, considerando que a deformação dúctil pode produzir rotações e alteração dos ângulos originais entre linhas pré-existentes, a situação não é tão simples.

Na figura 2.12 mostra-se um exemplo de resultado do modelo de Merle \& Gapais (1997). Notar que o componente direcional das "lineações" (direção $\mathbf{X}$ do elipsóide de deformação) poderia sugerir um movimento destral. Porém a componente transcorrente prescrita no modelo foi sinistral.

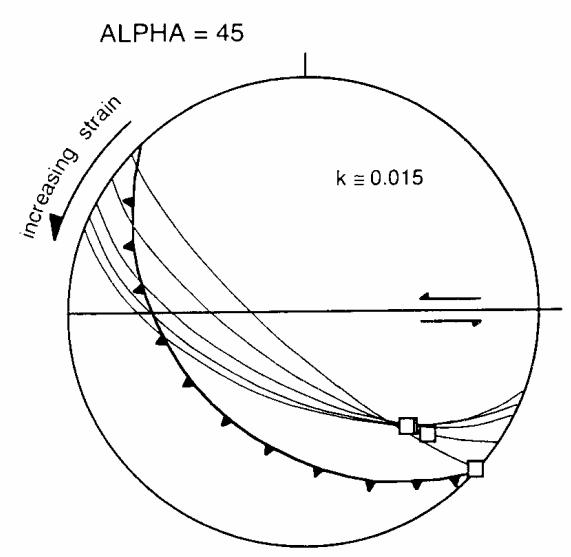

Figura 2.12 - Exemplo do modelo de Merle \& Gapais, mostrando empurrão inicial a N45W 30SW, seguido de transcorrência EW sinistral. Os círculos máximos em traço leve mostram a foliação prevista, e os quadrados a lineação, para cinco incrementos sucessivos de strain Hemisfério inferior do estereograma. (Merle \& Gapais, 1997, parte da figura 4). 
Situação semelhante também pode ser observada quanto à obliqüidade das lineações no modelo de Robin \& Cruden (1994).

No modelo modelo de empurrão seguido de transcorrência (Merle \& Gapais, op.cit.), atribuímos este efeito à rotação da "lineação" e da "foliação" associadas ao empurrão, pela transcorrência sobreposta. A questão pode ser assim visualizada: em um cisalhamento simples progressivo, com plano de cisalhamento vertical EW, as linhas pré-existentes tendem a girar para a direção EW horizontal, dentro de círculos máximos que contenham a lineação e a direção de cisalhamento. Se o movimento for destral, no bloco norte as linhas giram para a posição leste horizontal, e no bloco sul para oeste horizontal. Os planos tendem para a posição EW vertical (ou seja, seus pólos tendem a girar dentro de círculos máximos para a direção NS horizontal). Considerando um plano pré-existente com direção NE, mergulho para NW, e lineação nele contida no rumo de máximo mergulho (down dip), o efeito sobre das rotações do plano e lineação induzidos por cisalhamento simples transcorrente destral seria de tornar o plano mais empinado e próximo de $\mathrm{EW}$, e lineações com obliqüidade para NE, produzindo um efeito aparente de capa com movimento sinistral. 


\section{GEOLOGIA REGIONAL}

O autor vem trabalhando sistematicamente nesta região desde 1984, tendo coordenado e participado de equipes de mapeamento geológico (Campanha et al., 1985, 1988), desenvolveu sua tese de doutorado (Campanha, 1991), orientou estagiários, trabalho de formatura (Faleiros, 2000) e vem orientando dissertação de mestrado, bem como desenvolveu recentemente projeto financiado pela Fapesp na área em questão (Campanha, 2001).

São apresentadas aqui algumas compilações regionais nas quais o autor vem trabalhando nos últimos anos.

A figura 3.1 mostra a estruturação regional da porção meridional da Faixa Ribeira.

A figura 3.2, abrangendo parte da mesma área, mostra uma imagem resultante da interpolação dos dados aeromagnetométricos do projeto São Paulo - Rio de Janeiro, visto como um relevo sombreado, iluminado de NW. A imagem foi fornecida ao autor pelo geofísico André Rugenski (IAG/USP), que utilizou na sua elaboração o programa Surfer, com uma interpolação através do método do inverso do quadrado da distância, e um grid de $125 \mathrm{~m}$. Nesta imagem é nítida a configuração do sistema de zonas de cisalhamento.

O Anexo D tráz a compilação geológica da Folha Itararé em 1:250.000 (SG.22-X-B). O Anexo $E$ mostra o mapa estrutural da mesma folha. A presente versão foi preparada em formato digital, através dos programas Arclnfo e ArcView, com impressão por plotter a jato de tinta, a partir de versões preliminares disponível em Campanha et al. (1988, 1995). Sua preparação envolveu compilação, análise e reinterpretação de dados já existentes, integração com dados aerogeofísicos, imagens Landsat TM, imagem de radar, aliados a trabalhos de campo.

A geologia da região é caracterizada por um conjunto de rochas supracrustais, de grau metamórfico fraco a médio, denominado de Supergrupo Açungui.

O embasamento dessas supracrustais é constituído por um conjunto de rochas gnáissico - migmatíticas, com intercalações variadas de metassedimentos, e núcleos charnockíticos maiores mais a sul. Esse embasamento ocorre principalmente a sul do Lineamento Lancinha, e localizadamente a norte em alguns núcleos antiformais em meio às supracrustais.

Todas essas rochas são intrudidas por um grande número de corpos granitóides, com características variadas.

Ocorrem ainda algumas bacias tectônicas tardias, preenchidas com sedimentos e rochas vulcânicas, afetados por metamorfismo incipiente a fraco. Apresentam, em geral, franca discordância sobre as rochas anteriores. São interpretadas classicamente como uma fase molássica, com relação a orogênese brasiliana. São constituídas na região pelo Grupo Castro, pelas formações Camarinha, Guaratubinha e Quatis, e pelo Conglomerado Samambaia. Estão pelo menos em parte associadas ao sistema de zonas de cisalhamento transcorrentes, sendo provavelmente originadas dentro de contextos transtracionais do sistema. 


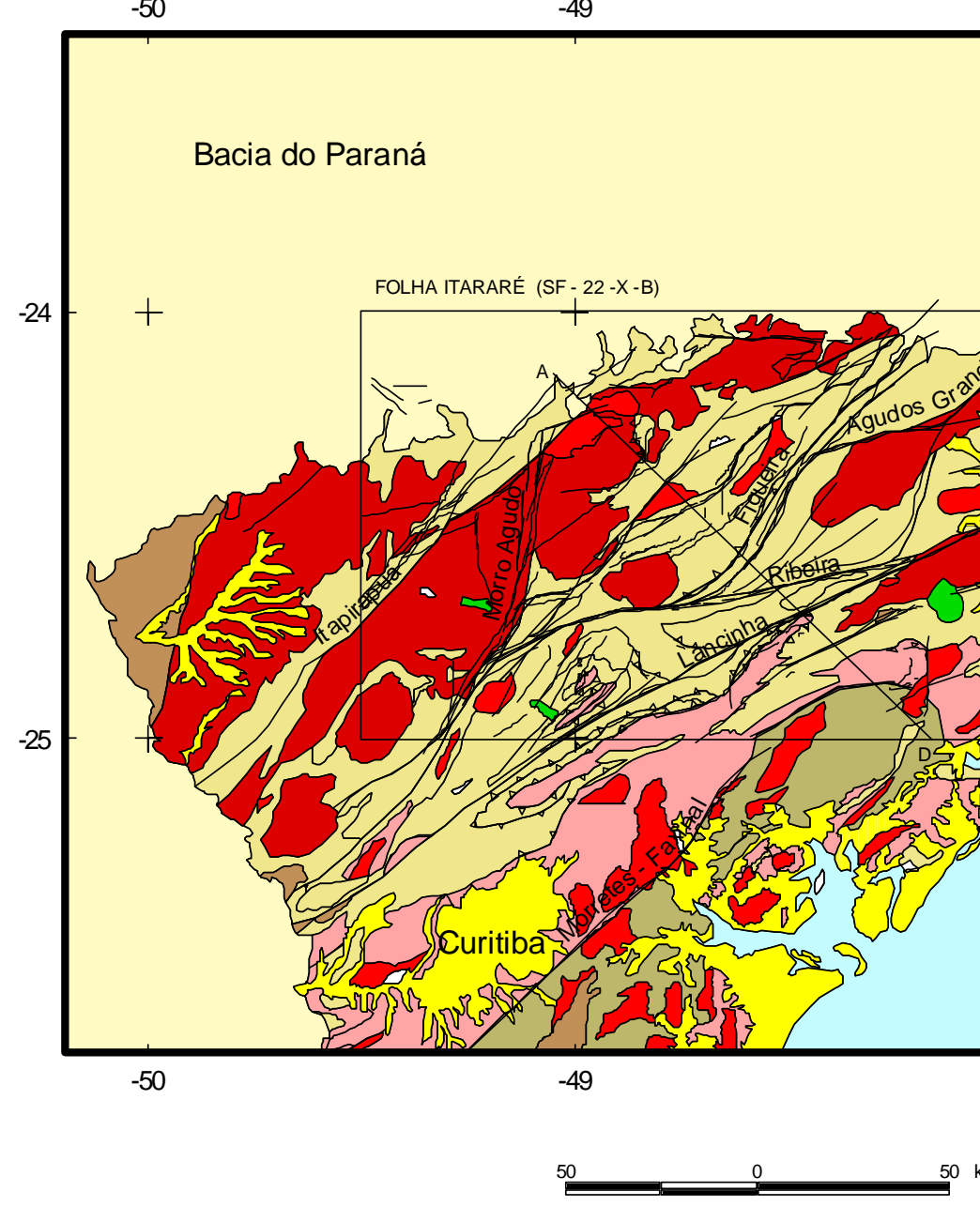

Figura 3.1 - Mapa Geológico da porção meridional da Faixa Ribeira
LEGENDA

CENOZÓICO

\begin{tabular}{ll}
\hline & Coberturas Sedimentares \\
MESOZÓICO & \\
\hline & Rochas Alcalinas
\end{tabular}

DEVONIANO A CARBONÍFERO

Bacia do Paraná

CAMBRIANO A NEOPROTEROZÓICO

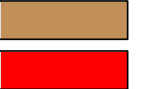

Depósitos Molassóides

Granittos Pós-tectônicos

NEOPROTEROZÓICO

Granitos Sin- a Tardi-tectônicos

NEO A MESOPROTEROZÓICO

NEO A PALEOPROTEROZÓICO

Gnaisses e migmatitos

PALEOPROTEROZÓICO A ARQUEANO

Gabros, Noritos e Charnockitos

- Ginaldo A. da C. Campanha 2002 


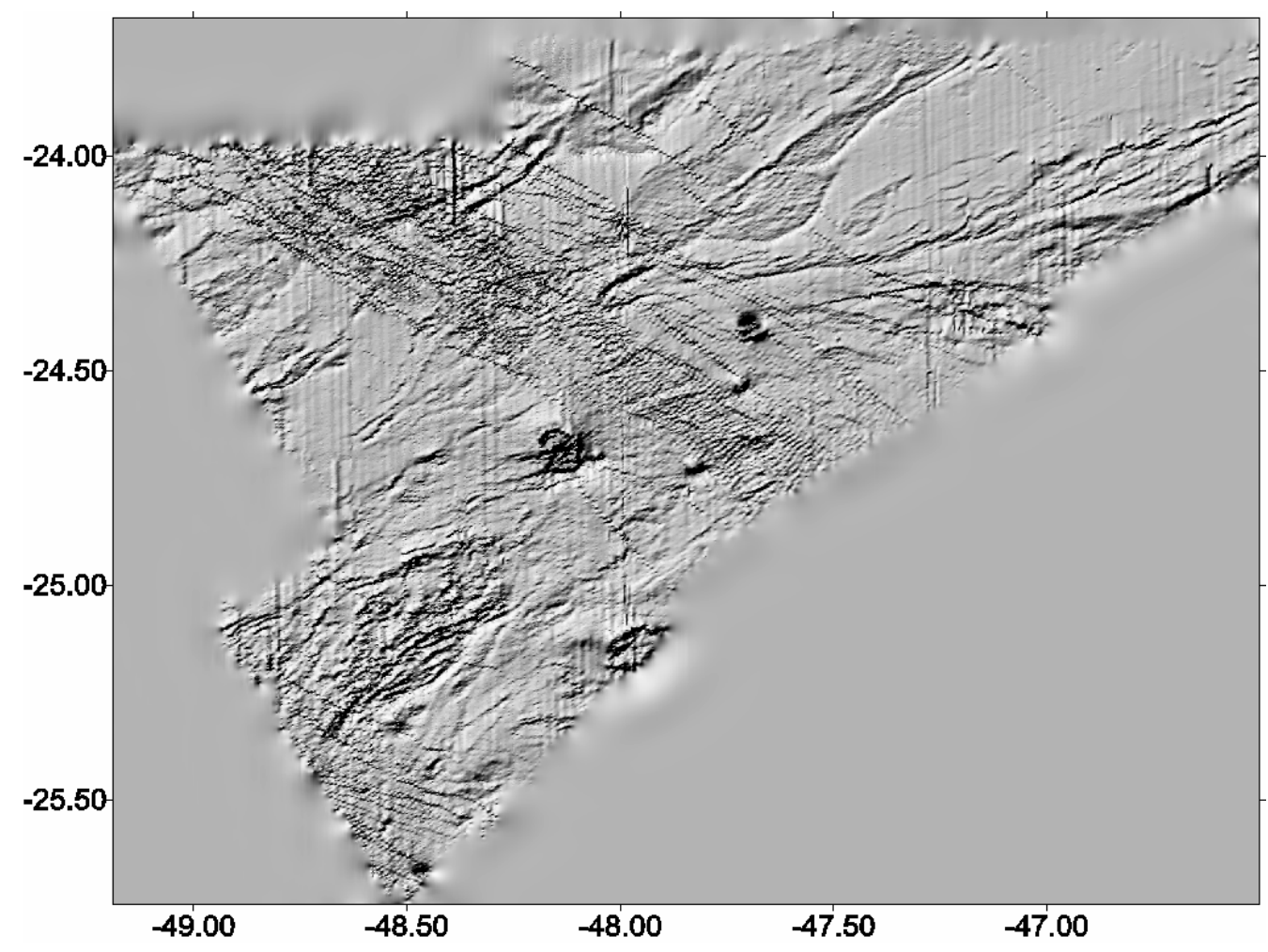

Figura 3.2 - Imagem com relevo sombreado de aeromagnetometria, com iluminação de NW e grid de 125 m (elaboração de André Rugenski, IAG/USP) 
As zonas de cisalhamento de maior importância regional, tanto em extensão e continuidade, como na delimitação de blocos tectônicos, são o Lineamento de Lancinha-Itapeúna, que se junta ao Lineamento Ribeira para formar o Lineamento Cubatão; os lineamentos de Morro Agudo, Quarenta - Oitava e Figueira, que parecem ser ramos divergentes do Ribeira; o Lineamento de Itapirapuã, mais ao norte, e o Lineamento Morretes - Faxinal, mais a sul.

Particularmente o Lineamento de Lancinha - Cubatão representa um limite mais importante entre terrenos distintos, separando as associações típicas do Cinturão Ribeira a norte, dos domínios Curitiba e Luís Alves a sul.

Assim distinguiremos aqui os domínios a sul e a norte do Lancinha.

\section{Terrenos a sul do Lineamento Lancinha}

Podem ser subdivididos nos domínios Curitiba e Luís Alves, seguindo a nomenclatura de Siga Jr. (1995), correspondendo às áreas de exposição dos complexos Gnáissico - Migmatítico e Costeiro (o qual inclui o Complexo Serra Negra ou Alto-Turvo, a Seqüência Cachoeira, e os gnaisses bandados da Serra do Azeite), seguindo a nomenclatura Itoestratigráfica adotada por Campanha \& Sadowski (1999).

No bloco a sul do Lineamento Lancinha predominam os indicadores cinemáticos sinistrais, como para a Falha do Braço Grande (Campanha et al. 1985) ou do Macaco Branco (Vasconcelos et al. 1999). Foi também identificada z.c. associada a expressiva faixa milonítica com indicadores sinistrais, a qual denominamos z.c. do Faxinal, e que representa o contato tectônico entre o Complexo Serra Negra (Domínio Luís Alves, de Siga Jr., 1995) e os complexos Turvo -Cajati e Gnáissico - migmatítico (Domínio Atuba de Siga Jr. op. cit.). Aparentemente é continuidade do Lineamento de Morretes, no Paraná. Como esta estrutura separa um bloco "frio" preservado desde o Paleoproterozóico ou mesmo Arqueano, consideramo-na como um importante elemento tectônico regional até então desconhecido.

No bloco entre a Lancinha e Faxinal, ocorrem a Formação Capiru, os xistos, paragnaisses, quartzitos e mármores do Complexo Turvo-Cajati, e o Complexo Gnáissico-migmatítico. A deformação conjunta do embasamento e da cobertura torna os contatos imbricados tectonicamente, sendo uma das causas principais das controvérsia sobre os limites destas unidades.

Evidências de aloctonia são observadas na porção basal da Formação Capiru, afetada por forte deformação associada a zonas de cisalhamento sub-horizontais, o mesmo ocorrendo com o Turvo-Cajati com relação ao Complexo Gnáissico-migmatítico. Esta situação por exemplo é observada na região da Barra do Turvo. Já na região da Barra do Azeite observa-se o Complexo Gnáissico-migmatítico fortemente milonitizado (gerando os "gnaisses bandados da Barra do Azeite") em contato tectônico sobre os xistos do Complexo Turvo-Cajati. 
As várias unidades litoestratigráficas clássicas desta área podem ser interpretadas como lascas tectônicas sobrepostas e delimitadas por essas zonas de cisalhamento subhorizontais. As lineações de estiramento denotam no entanto uma movimentação oblíqua à faixa móvel, com direções médias em torno de E/W. Dehler et al. (2000) propõem uma tectônica dúctil extensional nessa área, com movimentação das capas para ESE.

Considerando que estes sistemas de zonas de cisalhamento, com componente direcional em geral sinistral, são seccionados pela intrusão do Granito Guarau, deduz-se que sejam mais antigos que os sistemas destrais, que cortam até os granitos mais tardios.

A sul da zona de cisalhamento do Faxinal ocorre o Complexo Serra Negra, localmente constituído pela Suíte Gabro-anortosítica Alto Turvo, de Vasconcelos et al. (1999). As rochas apresentam estrutura e textura predominantemente isotrópicas e aparência ígnea, e assim prosseguem em direção para o sul, na área tipo do Cráton Luís Alves.

\section{Terrenos a norte do Lineamento Lancinha}

No bloco ao norte da Lancinha observa-se um padrão com estruturas compressivas com orientação NE, tais como o Lineamento da Figueira e os traços axiais das macrodobras do bloco do Lajeado e do anticlinório da Serra do Cadeado; estruturas predominantemente ENE, com movimentação destral nítida, tais como o Lineamento Ribeira; e estruturas NNE com movimentação sinistral, como por exemplo a porção norte do Lineamento do Morro Agudo.

Neste domínio o sistema de zonas de cisalhamento transcorrentes produz uma lenticularização tectônica regional, com macro-estruturas semelhantes a $S / C$ ou dúplexes transcorrentes, facilmente evidenciável nos mapas, definindo blocos tectônicos com formas sigmóides. A deformação associada é tipicamente heterogênea, concentrada ao longo de feixes estreitos de rochas com foliações e lineações extremamente paralelizadas, condicionando o desenvolvimento de lineamentos morfológicos. Desenvolvem milonitos quando os protólitos são favoráveis, e por vezes brechas e rochas cataclásticas stricto sensu. Apesar da deformação concentrar-se ao longo desses lineamentos, produz também efeitos notáveis nos blocos adjacentes, como rotações e inflexões nas estruturas pré-existentes da ordem de até dezenas de quilômetros.

As relações de interseção e deflexão entre estas estruturas sugerem uma seqüênciação temporal entre elas, sendo o Lineamento da Figueira (NE empurrão oblíquo) mais antigo, e deflexionado pelo Lineamento Ribeira (ENE destral), o qual por sua vez é deflexionado pelo Lineamento do Morro Agudo (NNE sinistral). O Lineamento Lancinha por sua vez intersecta todas estas estruturas.

Aqui o sistema de cisalhamento transcorrente sobrepõe-se a pelo menos dois grupos ou sistemas deformacionais anteriores. O primeiro grupo de estruturas tem sido atribuído a um processo de deformação rotacional, com direção de cisalhamento sub-horizontal paralela ou 
subparalela às camadas sedimentares originais. Produz freqüentemente um desmembramento $\mathrm{e}$ boudinage das camadas sedimentares, uma foliação (xistosidade ou clivagem ardosiana) paralela a subparalela ao acamamento, e raras dobras intrafoliais. O segundo grupo, que poderia ser puramente compressivo, produz em geral dobras mais abertas, com planos axiais empinados e eixos subhorizontais
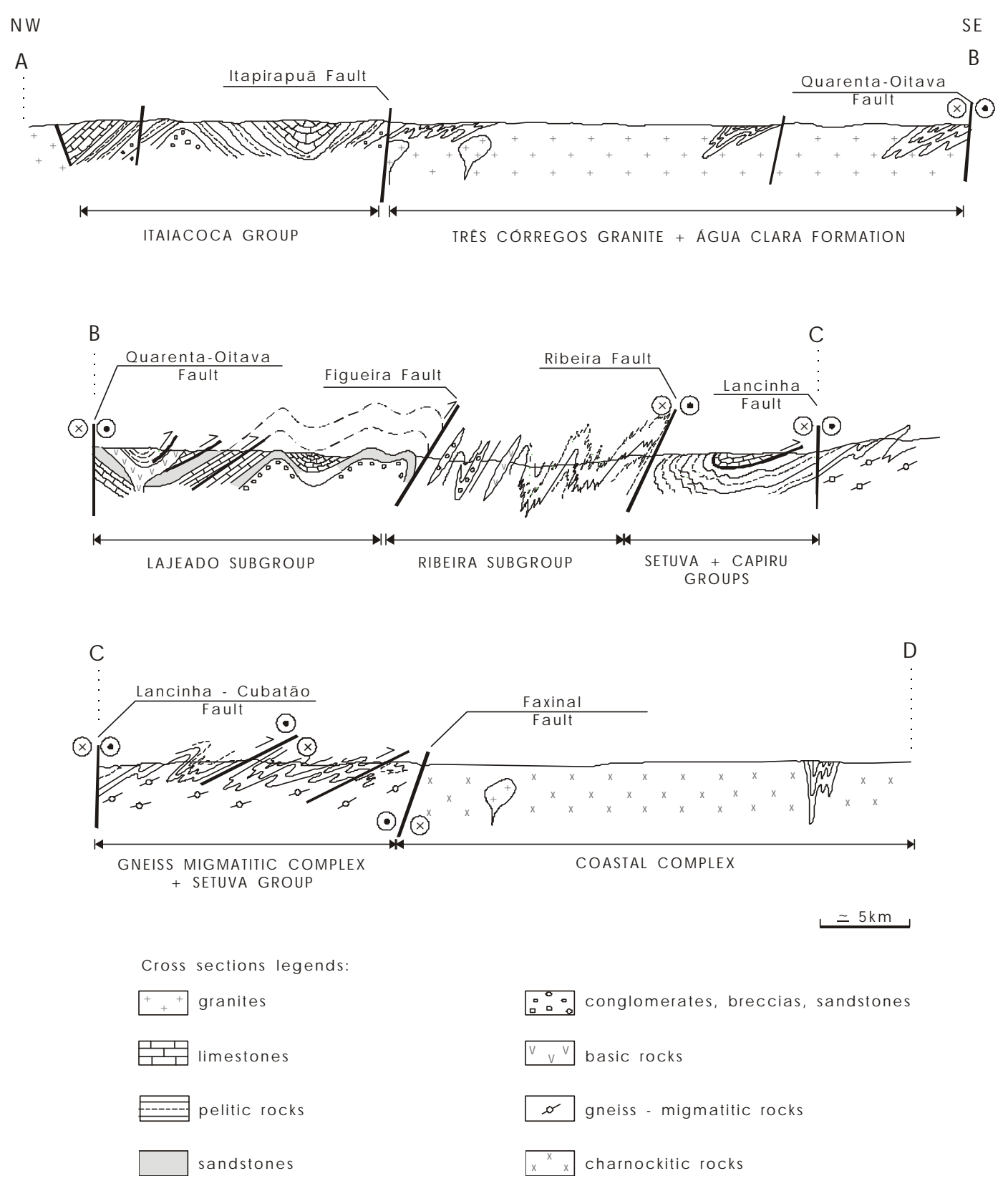

Figura 3.3 - Seção geológica através da porção meridional da Faixa Ribeira (modificado de Campanha \& Sadowski, 1999)

Predominam as lineações de estiramento subhorizontais ou oblíquas, de direção NE/SW, refletindo a intensidade e importância do evento transcorrente tardio. Uma tectônica transpressiva tem sido sugerida para a região. No entanto, pelo menos para o primeiro evento de cisalhamento 
de baixo ângulo, existem evidências sugestivas de uma direção de transporte perpendicular à faixa, para NW.

Ocorrem também zonas de cisalhamento subhorizontais associadas ao sistema transcorrente, com as zonas verticalizadas atuando como rampas laterais, e movimentação na direção ENE-WSW.

O Supergrupo Açungui, predominante neste bloco, é subdividido numa série de unidades, dispostas lateralmente em faixas longilíneas de orientação NE (Campanha et al., 1987, Campanha, 1991, Campanha e Sadowski, 1999). Seus contatos em geral são tectônicos, dados pelo sistema de zonas de cisalhamento transcorrentes. São reconhecidas subdivisões com empilhamento e colunas estratigráficas internas a cada uma dessas unidades, porém a correlação entre estas unidades maiores é essencialmente lateral, e não vertical (Figura 3.4).

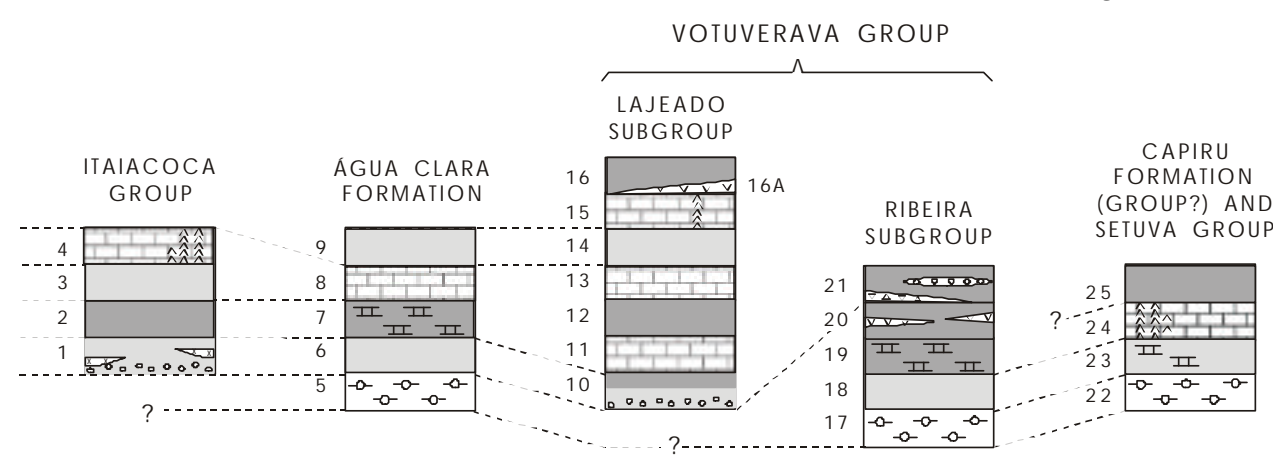

LEG END
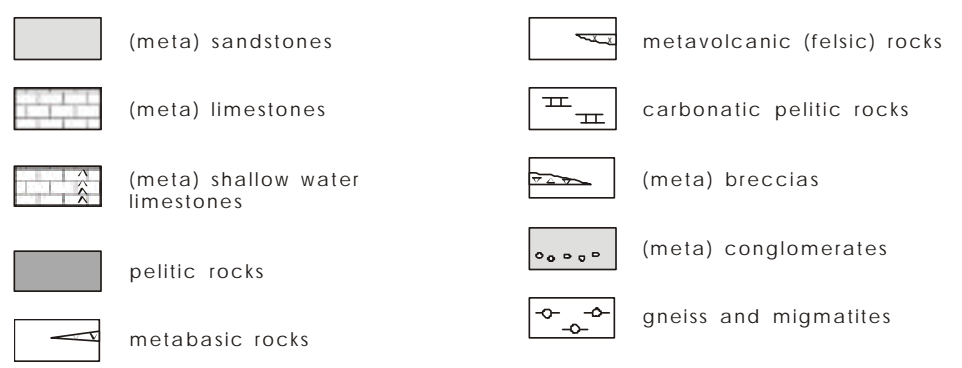

Figura 3.4 - Colunas estratigráficas e tentativas de correlação lateral no Supergrupo Açungui. (1) Formação Bairro da Estiva (Abapã); (2) Formação Água Nova; (3) Formação Serra dos Macacos; (4) Formação Bairro dos Campos; (5) embasamento gnáissico - migmatítico; (6) quartzitos e xistos; (7) seqüência calciossilicática; (8) seqüência calcária; (9) seqüência de meta-arenitos (Formação Córrego dos Marques); (10) Formação Betari; (11) Formação Bairro da Serra; (12) Formação Água Suja; (13) Formação Mina de Furnas; (14) Formação Serra da Boa Vista; (15) Formação Passa - Vinte; (16) Formação Gorutuba; (16A) Gabro de Apiai; (17) embasamento gnáissico - migmatítico; (18) Formação Perau, membro quartzítico; (19) Formação Perau, membro calciossilicático (mineralizado); (20) seqüência vulcanossedimentar (pelágico turbidítica); (21) Formação Iporanga; (22) embasamento gnáissico - migmatítico; (23) seqüência Morro Grande (= Turvo-Areado?); 24(Seqüência Rio Branco ( = Capela do Cedro?); (25) seqüência Juruqui (= Cajati?) (Campanha \& Sadowski, 1999). 
O norte da região é ocupado por dois grandes complexos granitóides de natureza cálcioalcalina, tidos como típicos de arco magmático, o Cunhaporanga e o Três Córregos. Entre eles ocorre uma longa faixa de rochas supracrustais de baixo grau metamórfico, conhecida como Grupo Itaiacoca. Um terceiro grande complexo granitóide, o de Agudos Grandes / Piedade, ocorre na porção mais central da área, afetando o Subgrupo Ribeira e o Complexo Embu.

O Grupo Itaiacoca apresenta, nos seus pacotes quartzíticos e carbonáticos mais espessos, um padrão estrutural aparentemente mais simples, com estruturas primária preservadas e dobramentos amplos. Um padrão de dobramento cerrado a isoclinal em escala mesoscópica é observado nos metapelitos mais incompetentes. Constitui-se de uma plataforma carbonática de águas rasas, com sedimentação dominada por lagunas, recifes e praias, com vulcanismo básico (região de Ribeirão Branco) e vulcanismo félsico de alto Potássio (região de Abapã) associados a sedimentação arcoseana. Embora tenha sido várias vezes interpretada como uma margem continental, o pequeno aporte de terrígenos e as vulcânicas associadas, bem como a não proximidade de uma margem cratônica na região, são mais indicativos de uma associação do tipo arco insular.

O Complexo Granítico Três Córregos é afetado por diversas intrusões mais tardias, e é em parte recoberto pela Formação Água Clara, a qual apresenta metamorfismo mais intenso, até grau médio, em parte de natureza termal, e intensa foliação sub-horizontal, associada a acamamento transposto, e redobrado.

As unidades da região central podem ser genericamente atribuídas ao Grupo Votuverava (Campanha e Sadowski, 1999, elevando a categoria da unidade clássica). É subdividido nos subgrupos Lajeado e Ribeira.

O Subgrupo Lajeado corresponde a uma plataforma carbonática com características de uma posição mais afastada da costa, de ambiente em geral não litorâneo, mas ainda sob a ação de ondas de tempestade. Para sudeste desta plataforma, ocorre o Subgrupo Ribeira, constituído de leques turbidíticos distais, seqüências possivelmente pelágicas e vulcânicas básicas toleíticas do tipo assoalho oceânico ou arco de ilhas pouco diferenciado. Todo o conjunto da porção central corresponde ao Grupo Votuverava clássico, sendo interpretado como uma margem continental aberta para o oceano

O Subgrupo Lajeado é constituído por formações siliciclásticas e carbonáticas alternadamente sobrepostas, intrudida em sua porção superior pelo Gabro de Apiaí. Limita-se a sul com a Formação Iporanga e o Subgrupo Ribeira através da zona de cisalhamento (Lineamento) da Figueira.

O Subgrupo Lajeado em sua porção central aflorante (e.g. estrada Apiaí a Iporanga), apresenta padrão estrutural aparentemente simples. É dominado por uma série de anticlinais e sinclinais, os maiores com comprimentos de onda da ordem de centenas de metros a poucos quilômetros, com planos axiais empinados, com mergulho forte para NW, eixos subhorizontais e uma clivagem ardosiana em posição plano-axial, e com vergência estrutural para SE. O 
empilhamento estratigráfico original está aparentemente preservado, embora existam suspeitas da repetição tectônica de alguns pacotes por deslocamentos (falhas oblíquas de baixo ângulo) ao longo dos contatos entre os pacotes maiores. Ocorrem mais duas fases de dobramentos sobrepostas, associadas a clivagens de crenulação, uma com direção NE e outra, mais tardia, com direção NW. Nos seus limites mais externos são observáveis zonas de cisalhamento associadas a deformação mais intensa, com movimentos, tanto do tipo inverso, como no limite SE, dado pelo Lineamento da Figueira, como transcorrentes, como no limite NW, dados pelas zonas de cisalhamento de Quarenta - Oitava e Espirito Santo. Estas feições nas suas bordas, o formato regional em mapa, o caráter en echelon e terminações cônicas das macrodobras sugerem que o Subgrupo Lajeado ocorra como uma macrolente regional de cisalhamento.

O Subgrupo Ribeira, incluindo as formações Iporanga e Perau, apresenta estilo deformacional mais intenso, com dobramento cerrado e transposição em escala de afloramento associado à primeira fase de deformação. Porém, a clivagem gerada nessa fase é contínua e paralela com a observada no Subgrupo Lajeado, sendo também paralelos nestas unidades os eixos, planos axiais e o sentido da vergência estrutural. Sobrepõem-se ainda duas fases de dobramento, com orientações similares às do Lajeado. Estes dados levam a crer que o Subgrupo Lajeado e as formações Iporanga e Perau foram afetados essencialmente pelas mesmas fases deformacionais. No entanto, enquanto no Lajeado o empilhamento original está pelo menos em parte preservado, no Subgrupo Ribeira as diversas intercalações litológicas apresentam forma lenticular, com clivagem tectônica paralelizada aos contatos litológicos em todas as escalas, estando possivelmente totalmente desmembrados os contatos e as posições estratigráficas originais.

O Subgrupo Ribeira é seccionado pelo Lineamento Ribeira. No bloco a norte, o grau metamórfico é fraco (zona da clorita) a incipiente, com estruturas sedimentares reliquiares em geral bem preservadas, apesar da forte deformação tectônica. Conforme se passa para o domínio a sul do Lineamento Ribeira, o grau metamórfico aumenta, o padrão estrutural passa a ser dominado pela presença de um dobramento de maior escala associada a uma segunda fase de dobramento, afetando uma xistosidade paralela aos contatos litológicos. No Paraná este dobramento é amplo e aberto, configurando uma série de estruturas antiformais (Anta Gorda, Perau, Cerne, Betara etc.) e sinformais. O conjunto maior e mais setentrional dessas estruturas foi denominado de anticlinório da Serra do Cadeado. Este dobramento aberto provavelmente é devido ao controle exercido pelo pacote quartzítico espesso e competente da base da Formação Perau.

O Subgrupo Ribeira no geral constitui-se predominantemente de metapelitos (predominantemente metarritmitos) de granulação fina a muito fina, em geral intensamente deformados. Subordinadamente ocorrem metabasitos, metamargas, metacalcários, metarenitos, metaconglomerados oligomíticos, formações ferríferas de pequeno porte e lâminas de metacherts. Os metapelitos têm sido interpretados como associados a leques turbidíticos distais e folhelhos 
pelágicos, enquanto que as metabásicas apresentam assinatura litoquímica característica de assoalho oceânico e arco de ilhas imaturo.

As porções superiores do Subgrupo Ribeira são constituídas pela Formação Iporanga. Esta é constituída por metarritmitos finos, com intercalações de metarenitos, metaconglomerados e metabrechas polimíticas. Em parte seu contato com o restante do Subgrupo Ribeira é de natureza tectônica, dado através do Lineamento de Agudos Grandes. Em outros locais entretanto esse contato parece ser discordante, com a brecha basal da Formação Iporanga sobreposta a metargilitos e metavulcânicas do Subgrupo Ribeira. Apesar dessa posição de topo dentro do Subgrupo Ribeira, permanecem dúvidas quanto ao hiato de tempo entre a deposição da Formação Iporanga e o restante das unidades subjacentes. A Formação Iporanga tem recebido diversas interpretações em termos de paleoambiente: tilitos, turbiditos distais, molassas, wildflysh, debris flowe turbiditos canalizados.

As porções mais basais do Subgrupo Ribeira correspondem à Formação Perau. Foi definida em uma série de estruturas antiformais e sinformais abertas, de comprimento de onda quilométrico, no bloco entre os Lineamentos de Lancinha e Agudos Grandes / Ribeira, no Estado do Paraná. No núcleo das antiformas ocorrem rochas gnáissicas, fortemente milonitizadas, com intercalações de xistos feldspáticos e quartzitos, atribuídas ao Complexo Gnaíssico - Migmatítico. A base da Formação Perau é constituída por um pacote de quartzitos, espesso de centenas de metros e contínuo por dezenas de quilômetros, o qual provavelmente condiciona o estilo aberto dos dobramentos maiores. São capeados por um pacote de carbonato xistos que abriga os níveis mineralizados das minas do Perau e Canoas, bem como uma série de ocorrências e depósitos menores. Segue-se um pacote de xistos e filitos com intercalações menores de anfibolitos. 


\section{ANÁLISE DA DEFORMAÇÃO NO MÉDIO RIBEIRA}

Neste capítulo procuraremos integrar alguns dados de strain já obtidos (Campanha, 1991, Campanha e Sadowski, 2002), com dados complementares, análises de variação volumétrica, e análise da geometria da zona de cisalhamento correspondente ao Lineamento Ribeira.

\subsection{Determinações do strain finito}

\subsubsection{Introdução}

Estimativas quantitativas da deformação finita (finite strain) foram realizadas em metassedimentos do Supergrupo Açungui, subgrupos Lajeado e Ribeira, na região do Alto e Médio Vale do Ribeira, SP (figura 4.1). Os objetivos foram a obtenção de dados que contribuíssem para avaliar as espessuras originais dos metassedimentos da área, o encurtamento tectônico sofrido, bem como mapear a orientação dos eixos principais e o tipo de elipsóide de deformação. Estes últimos parâmetros são importantes para o estabelecimento de modelos deformacionais que expliquem as associações de estruturas observadas.

Para efeito de análise, a área foi dividida em blocos tectônicos, separados por grandes zonas de cisalhamento. Reconhece-se o bloco Apiaí a norte, delimitado pelas falhas do Espirito Santo e Carumbé; o Bloco Lajeado, delimitado pela Falha do Carumbé e Lineamento Figueira; o Bloco Ribeira, delimitado pelos lineamentos Figueira e Ribeira; e o Bloco Andorinhas, a sul do Lineamento Ribeira.

O Bloco Lajeado na área é composto pelo Subgrupo Lajeado e porções dos granitos Itaoca e Vargem Grande. O Bloco Ribeira por sua vez é composto pela Formação Iporanga e pelo Subgrupo Ribeira indiviso.

As unidades do Bloco Ribeira caracterizam-se por uma deformação mais intensa, com dobramento fechado a isoclinal e transposição das camadas sedimentares para a posição da clivagem ardosiana, a qual é contínua através dos blocos Lajeado e Ribeira, com mergulhos médios fortes em geral para NW. Esta foliação principal é defletida pelo Lineamento Ribeira, passando de direções NE a norte, para ENE, nas proximidades do Lineamento Ribeira.

As estimativas de deformação finita foram possíveis nos blocos Lajeado e Ribeira (incluindo a Formação Iporanga), onde o grande número de estruturas e texturas reliquiares preservadas permite que se compare a configuração final deformada (observável), com a suposta configuração geométrica original para estas estruturas e texturas.

Procurou-se adotar os métodos mais simples e rápidos existentes na literatura especializada. Julgou-se que nesta abordagem preliminar do problema seria mais importante obter um maior número de estimativas semi-quantitativas, mas distribuídas regionalmente, do que uma ou duas determinações extremamente precisas e localizadas. 
Apresenta-se 15 determinações completas do elipsóide de deformação, cujas locações encontram-se representadas na figura 4.1 e os resultados na tabela 4.1. Nestes 15 casos foram determinadas as orientações dos três eixos principais do elipsóide de deformação, $(\mathbf{X}, \mathbf{Y}, \mathbf{Z})$, bem como as razões entre as três extensões principais $\left(S_{1}: S_{2}: S_{3}\right)$.
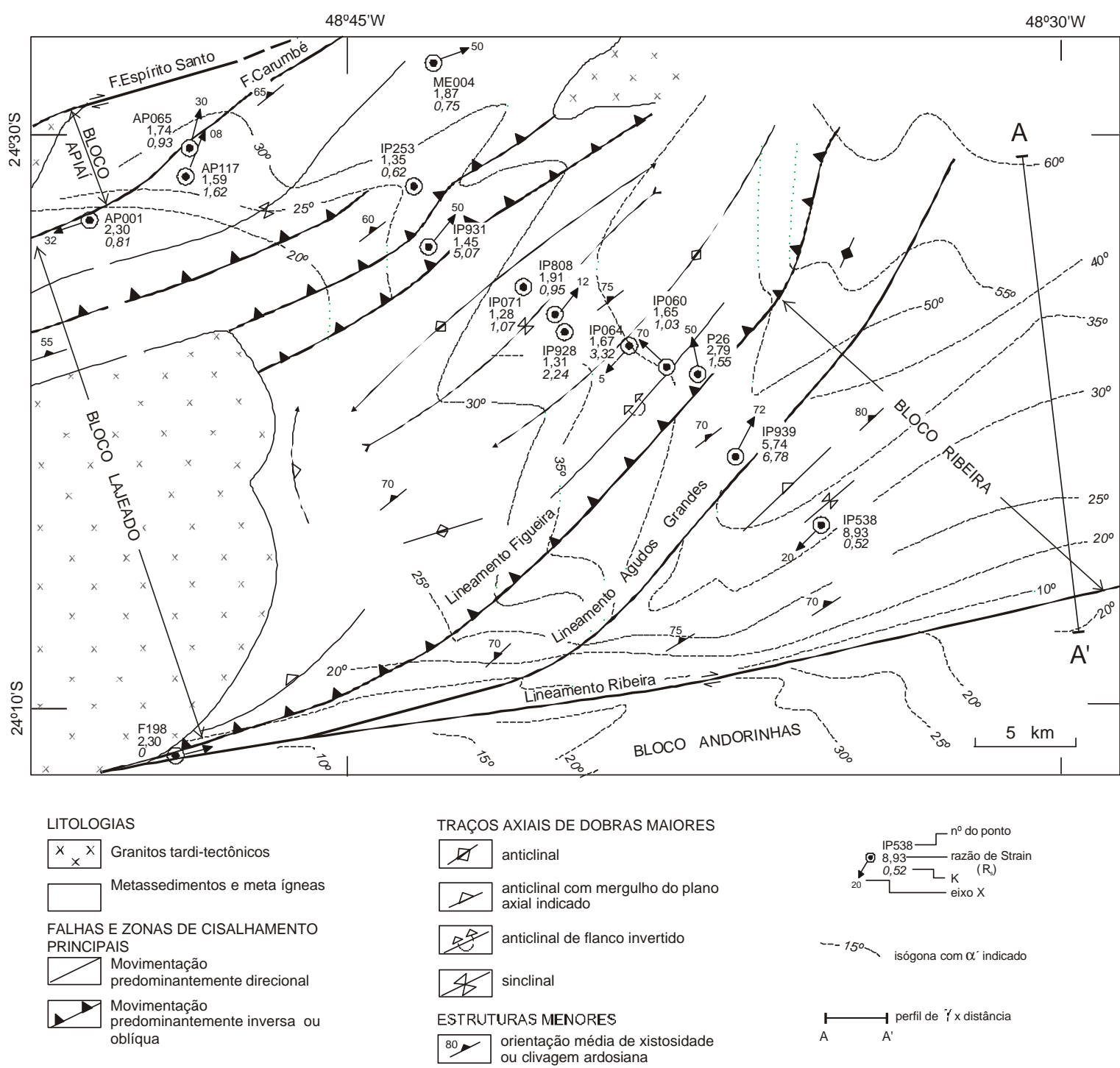

Figura 4.1 - Mapa estrutural simplificado da área estudada, mostrando os pontos nos quais foram realizadas medidas de deformação finita, com indicação dos valores obtidos de $R_{S}\left(S_{1} / S_{3}\right)$ e $K$, atitudes do eixo $X$ do elipsóide de deformação finita e traçados de isógonas das linhas de tendência média das estruturas na região de influência do Lineamento Ribeira. A porção sul do Lineamento Ribeira foi tomada como direção de referência $\left(\alpha=0^{\circ}\right)$ para o traçado das isógonas. 


\begin{tabular}{|l|c|c|c|c|c|c|c||}
\hline PONTO & AP001 & AP65B & AP117 & IP060B & IP064G & IP071C & IP253B \\
\hline Extensões $\left(\mathrm{S}=\mathrm{l}_{1} / \mathrm{l}_{0}\right)$ relativas, considerando $\mathrm{S}_{\mathrm{y}}=1$ & \multicolumn{1}{|l||}{} \\
\hline $\mathbf{X}$ & 1.46 & 1.31 & 1.32 & 1.29 & 1.46 & 1.13 & 1.12 \\
\hline $\mathbf{Y}$ & 1 & 1 & 1 & 1 & 1 & 1 & 1 \\
\hline $\mathbf{Z}$ & 0.64 & 0.75 & 0.83 & 0.78 & 0.88 & 0.88 & 0.83 \\
\hline $\mathbf{X} / \mathbf{Z}$ & 2.30 & 1.74 & 1.59 & 1.65 & 1.67 & 1.28 & 1.35 \\
\hline $\mathbf{K}$ & 0.81 & 0.93 & 1.62 & 1.03 & 3.32 & 1.02 & 0.62 \\
\hline Atitudes dos eixos principais de deformação finita & $258 / 32$ & $012 / 30$ & $023 / 08$ & $310 / 70$ & $222 / 05$ & $180 / 62$ & $284 / 20$ \\
\hline $\mathbf{X}$ & $114 / 52$ & $279 / 02$ & $286 / 46$ & $217 / 03$ & $015 / 84$ & $336 / 26$ & $017 / 10$ \\
\hline $\mathbf{Y}$ & $359 / 19$ & $181 / 60$ & $120 / 43$ & $127 / 20$ & $132 / 03$ & $070 / 09$ & $132 / 68$ \\
\hline $\mathbf{Z}$ & quartzito & meta-aren. & meta-aren. & meta-siltito & meta-aren. & calcário & meta-aren. \\
\hline rocha & S.Boa Vista & S.Boa Vista & S.Boa Vista & Betari & Betari & B. da Serra & S.Boa Vista \\
\hline unidade
\end{tabular}

\begin{tabular}{|l|c|c|c|c|c|c|c|c|c||}
\hline PONTO & IP808B & IP928 & IP931 & ME004 & P26 & IP939B & IP538 & F198 \\
\hline \multicolumn{7}{|l|}{ Extensões $\left(\mathrm{S}=1_{1} / 1_{0}\right)$ relativas, considerando $\mathrm{S}_{\mathrm{y}}=1$} \\
\hline $\mathbf{X}$ & 1.37 & 1.20 & 1.35 & 1.32 & 1.82 & 3.99 & 2.41 & 1 \\
\hline $\mathbf{Y}$ & 1 & 1 & 1 & 1 & 1 & 1 & 1 & 1 \\
\hline $\mathbf{Z}$ & 0.72 & 0.92 & 0.93 & 0.70 & 0.65 & 0.69 & 0.27 & 0.435 \\
\hline $\mathbf{X} / \mathbf{Z}$ & 1.91 & 1.31 & 1.45 & 1.87 & 2.78 & 5.74 & 8.93 & 2.30 \\
\hline $\mathbf{K}$ & 0.95 & 2.24 & 5.07 & 0.75 & 1.55 & 6.78 & 0.52 & \\
\hline Atitudes dos eixos principais de deformação finita & & & & & \\
\hline $\mathbf{X}$ & $030 / 12$ & $179 / 27$ & $042 / 50$ & $068 / 50$ & $348 / 50$ & $025 / 72$ & $224 / 20$ & $073 / 02$ \\
\hline $\mathbf{Y}$ & $240 / 75$ & $280 / 20$ & $275 / 28$ & $262 / 47$ & $218 / 28$ & $255 / 12$ & $020 / 68$ & $338 / 72$ \\
\hline $\mathbf{Z}$ & $120 / 08$ & $046 / 58$ & $169 / 27$ & $165 / 07$ & $114 / 26$ & $162 / 02$ & $131 / 10$ & $164 / 18$ \\
\hline rocha & calcário & \multicolumn{2}{|l|}{ calcário } & calcário & meta-siltito & calcário & meta-congl. & meta-congl. & meta-congl. \\
\hline unidade & B. da Serra & B. da Serra & M. Furnas & Gorutuba & B. da Serra & Iporanga & Ribeira & Iporanga \\
\hline
\end{tabular}




\subsubsection{Procedimentos Adotados}

O procedimento básico consistiu na determinação das elipses de deformação em três seções não paralelas entre si de cada amostra. A partir destas três seções efetuou-se a dedução do elipsóide de deformação. Em 35 seções utilizou-se o método de Fry (Fry, 1979; Ramsay \& Huber, 1983) para a análise de distribuição de grãos em metarenitos e metassiltitos. Cristais de rutilo que sofreram boudinage foram utilizados em uma seção para se determinar a elongação em várias direções. Em uma amostra de metabrechas foram aplicados três métodos distintos em cada corte $\left(R_{F} / \phi\right.$, orientação preferencial e média harmônica). Por meio da média harmônica da elipsidade dos seixos determinou-se, em um afloramento de metaconglomerados, a elipse de deformação em duas seções. Os resultados por seção, com o método utilizado em cada uma, são mostrados na tabela 4.2.

\begin{tabular}{|c|c|c|c|c|c|c|c|c|c|}
\hline Seção & A & B & $\mathrm{C}$ & A & B & $\mathrm{C}$ & A & $\mathrm{B}$ & $\mathrm{C}$ \\
\hline Amostra & \multicolumn{3}{|c|}{ AP001 } & \multicolumn{3}{|c|}{ AP065B } & \multicolumn{3}{|c|}{ AP117 } \\
\hline método utilizado & Fry & Fry & Fry & Fry & Fry & Fry & Fry & Fry & Fry \\
\hline Atitude da seção & $019 / 72$ & $150 / 60$ & $237 / 38$ & $100 / 78$ & $005 / 60$ & $206 / 38$ & $269 / 88$ & $178 / 56$ & $359 / 42$ \\
\hline Rs medida & 1.75 & 1.13 & 2.2 & 1.57 & 1.07 & 1.33 & 1.15 & 1.65 & 1.11 \\
\hline Rs ajustada & - & - & - & - & - & - & 1.21 & 1.31 & - \\
\hline rake eixo maior medido & 148 & 85 & 63 & 33 & 103 & 30 & 20 & 147 & 60 \\
\hline rake do eixo maior ajustado & 148 & 110 & 63 & 33 & 103 & 10 & 172 & 137 & 130 \\
\hline Amostra & \multicolumn{3}{|c|}{ IP60B } & \multicolumn{3}{|c|}{ IP064G } & \multicolumn{3}{|c|}{ IP071C } \\
\hline método utilizado & Fry & rutilos & Fry & Fry & Fry & Fry & Fry & Fry & Fry \\
\hline Atitude da seção & $130 / 24$ & $304 / 64$ & $036 / 88$ & $219 / 03$ & $040 / 82$ & $121 / 86$ & $296 / 80$ & $191 / 42$ & $034 / 60$ \\
\hline Rs medida & 1.5 & 1.14 & 1.54 & 1.67 & 1.13 & 1.44 & 1.16 & 1.24 & 1.09 \\
\hline Rs ajustada & - & - & - & - & - & - & - & - & - \\
\hline rake eixo maior medido & 22 & 122 & 68 & 90 & 93 & 176 & 122 & 72 & 62 \\
\hline rake do eixo maior ajustado & - & - & - & - & - & - & 76 & - & - \\
\hline Amostra & \multicolumn{3}{|c|}{ IP253B } & \multicolumn{3}{|c|}{ IP808B } & \multicolumn{3}{|c|}{ IP928 } \\
\hline método utilizado & Fry & Fry & Fry & Fry & Fry & Fry & Fry & Fry & Fry \\
\hline Atitude da seção & $183 / 79$ & $085 / 14$ & $282 / 78$ & $324 / 16$ & $213 / 82$ & $306 / 78$ & $309 / 22$ & $193 / 80$ & $096 / 70$ \\
\hline Rs medida & 1.31 & 1.00 & 1.12 & 1.44 & 1.81 & 1.26 & 1.25 & 1.20 & 1.43 \\
\hline Rs ajustada & - & - & - & 1.79 & 1.60 & - & - & 1.00 & 1.27 \\
\hline rake eixo maior medido & 164 & - & 168 & 164 & 94 & 170 & 10 & - & 160 \\
\hline rake do eixo maior ajustado & - & - & - & 150 & - & - & - & - & 150 \\
\hline Amostra & \multicolumn{3}{|c|}{ IP931 } & \multicolumn{3}{|c|}{ ME004 } & \multicolumn{3}{|c|}{$\mathrm{P} 26$} \\
\hline método utilizado & Fry & Fry & Fry & Fry & Fry & Fry & Fry & Fry & Fry \\
\hline Atitude da seção & $332 / 53$ & $199 / 54$ & $082 / 62$ & $318 / 62$ & $209 / 60$ & $078 / 40$ & $311 / 60$ & $045 / 84$ & $132 / 38$ \\
\hline Rs medida & 1.33 & 1.15 & 1.27 & 1.00 & 1.62 & 1.87 & 1.07 & 2.55 & 1.50 \\
\hline Rs ajustada & - & - & - & - & - & - & - & - & - \\
\hline rake eixo maior medido & 154 & 0 & 75 & - & 88 & 82 & 30 & 56 & 164 \\
\hline rake do eixo maior ajustado & - & - & - & - & - & - & - & - & - \\
\hline Amostra & \multicolumn{3}{|c|}{ IP939B } & \multicolumn{3}{|c|}{ IP538 } & \multicolumn{3}{|c|}{ F198 } \\
\hline método utilizado & $\mathrm{Rf} / \phi$ & $\mathrm{Rf} / \phi$ & $\mathrm{Rf} / \phi$ & m.h. & m.h. & - & m.h. & m.h. & \\
\hline Atitude da seção & $072 / 76$ & $266 / 14$ & $167 / 86$ & $359 / 72$ & $312 / 82$ & - & $228 / 78$ & $152 / 23$ & \\
\hline Rs medida & 5.00 & 2.40 & 4.60 & 2.65 & 2.41 & - & 2.29 & 2.30 & \\
\hline Rs ajustada & 5.76 & 1.74 & 3.83 & - & - & - & - & - & \\
\hline rake eixo maior medido & 76 & 105 & 82 & 98 & 20 & - & 0 & 0 & \\
\hline rake do eixo maior ajustado & - & - & 86 & - & - & - & & & \\
\hline
\end{tabular}

Tabela 4.2 - Resultados obtidos para cada uma das seções das amostras analisadas. 
Para a integração das três seções de medida para a dedução do elipsóide de deformação, adaptou-se o método gráfico proposto por De Paor (1986).

O procedimento adotado, na maior parte das determinações, pode ser dividido em três etapas básicas: preparação, determinação das elipses de deformação e dedução do elipsóide de deformação, conforme segue e ilustrado na figura 4.2.

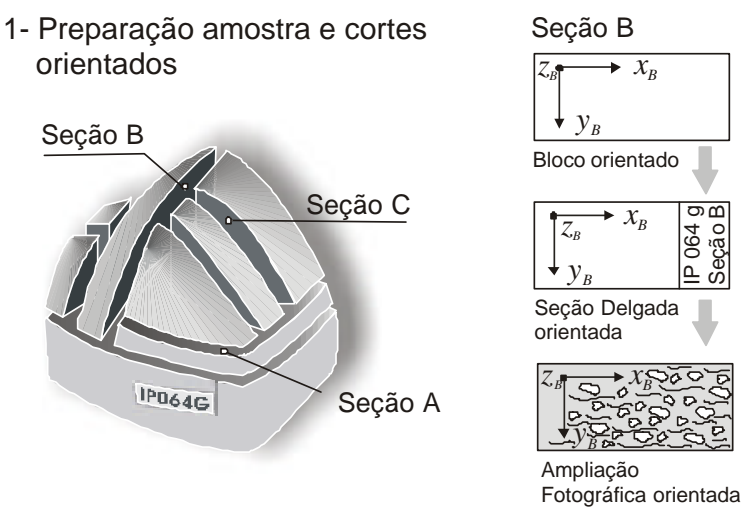

3- Ajuste de compatibilidade entre as elipses

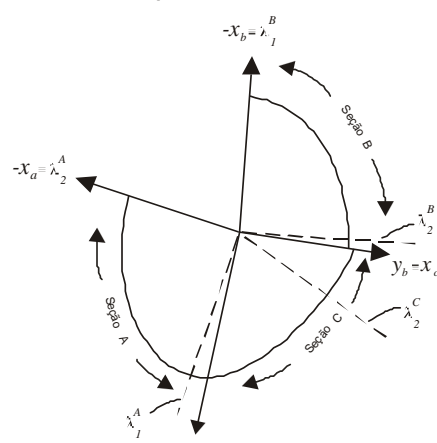

2- Determinação da elipse em cada seção

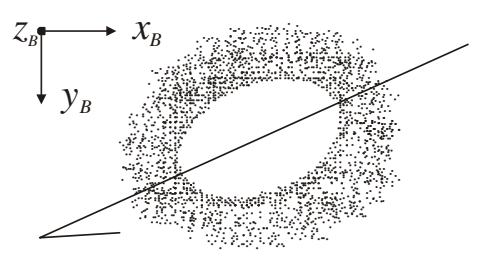

4- Determinação dos eixos principais de deformação

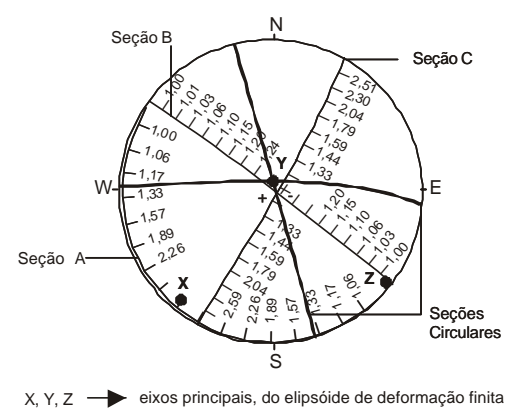

Figura 4.2 - Esquema da seqüência de procedimentos utilizada.

a) Preparação

1) Foram coletadas amostras orientadas, procurando representar cada unidade litoestratigráfica, em cada uma de suas situações estruturais, ao longo de um perfil aproximadamente NW/SE, como se vê na figura 4.1.

2) Foram escolhidos e marcados três cortes não paralelos entre si por amostra. Na medida do possível, os cortes foram ortogonais entre si e, de preferência, ortogonais e paralelos à foliação e lineação.

3) Depois de serrada a amostra, foi elaborado um esboço mostrando a disposição dos blocos cortados e a face orientada, para eventual conferência posterior.

4) Em cada corte, foi marcada a localização de uma seção delgada, e marcados três eixos de referência orientados e ortogonais entre si. 
5) A amostra foi fixada na sua orientação original com relação às coordenadas geográficas; a atitude de cada seção foi medida com bússola e lançada em rede estereográfica. Os ângulos entre as faces cortadas foram conferidos na amostra e no diagrama, e, quando necessário, ajustadas as atitudes das seções.

6) Nas seções delgadas de cada corte também foram marcados os três eixos de referência.

7) Efetuaram-se ampliações fotográficas de cada lâmina numa escala que permitisse a perfeita individualização dos grãos clásticos e a aplicação do método de Fry, marcando-se os três eixos de referência na respectiva ampliação fotográfica.

b) Determinação da elipse de deformação em cada seção

Em um overlay sobreposto a cada seção, foram determinados os respectivos centros dos grãos clásticos e, em seguida, em um segundo overlay, foi aplicado o método de Fry, manualmente. Obtida a elipse pelo método de Fry, foi determinada a elipsidade (ou razão de strain, $\mathrm{R}_{\mathrm{s}}$ ), bem como a orientação do eixo maior com relação aos eixos de referência.

Os métodos adotados não permitem em geral estimar-se os estiramentos absolutos sofridos, já que não se tem as dimensões absolutas originais dos grãos medidos; deste modo obtém-se apenas as razões entre os estiramentos máximos e mínimos $\left(R_{s}\right)$.

c) Determinação do elipsóide

Determinadas as elipses de deformação em três seções quaisquer da amostra, é possível teoricamente obter as orientações e as elongações principais do elipsóide de deformação. Destarte, é possível abster-se de quaisquer pressupostos iniciais a respeito das orientações dos eixos e das respectivas seções principais. Este não é o procedimento mais comum na literatura de análise de strain, onde, em geral, se pressupõe que a xistosidade e a lineação correspondam respectivamente ao plano $\mathbf{X Y}$ e ao eixo $\mathbf{X}$ do elipsóide, procurando-se realizar medidas nessas seções.

No caso de três seções ortogonais entre si, coincidindo com as seções principais do elipsóide de deformação, a resolução do problema é bastante simples. Os eixos das elipses de cada seção correspondem aos eixos principais do elipsóide. No entanto, a partir do momento que as seções de medida não coincidem mais com as seções principais do elipsóide, e as seções de medida não sejam mais ortogonais entre si, os eixos das elipses em cada seção não coincidem mais necessariamente com os eixos principais do elipsóide de deformação finita (Ramsay, 1967).

Experimentou-se três métodos distintos para a determinação do elipsóide tridimensional, respectivamente propostos por Ramsay (1967), Milton (1980) e De Paor (1986). 
Os métodos de Ramsay (op.cit.) e de Milton (op.cit.) são algébricos ou matriciais e, basicamente, calculam os coeficientes da matriz do tensor de deformação finita. A partir daí calculam os parâmetros essenciais do elipsóide respectivo. Por sua vez, De Paor (op.cit.) desenvolve um método totalmente gráfico.

Os métodos de Ramsay (1967), e Milton (1980) foram implementados em computador e testados em casos construídos para tal fim. Notou-se que, quando as seções de medida aproximam-se dos planos principais de deformação, os resultados são coerentes. Mas, quando se trabalha com seções quaisquer, podem surgir resultados espúrios. De Paor (op.cit.) analisa esta situação e argumenta que pequenos erros de medida e de ajuste, principalmente nos componentes de cisalhamento do tensor, podem produzir grandes diferenças no final dos cálculos. Assim, preferiu-se adotar os métodos gráficos que, embora mais trabalhosos e aparentemente menos precisos, permitem um controle visual da distribuição das elongações nas várias direções, evitando erros grosseiros.

O método aqui adotado, adaptado daquele proposto por De Paor (op.cit.), consiste em três etapas, descritas a seguir.

\section{Ajuste de compatibilidade entre as elipses das seções de medida}

Como as seções de medida são cortes do mesmo elipsóide tridimensional, as linhas de interseções entre elas devem ter elongações iguais. Como as elipses obtidas são o resultado de um processo real de medida, sempre incorporam um certo erro, tornando-se necessário um ajuste de compatibilidade. Caso as elipses nas intersecções entre as seções não coincidam, são feitos ajustes de escala, orientação e/ou elipsidade (De Paor, 1986).

\section{Determinação das direções principais de deformação pela construção de Biot-Fresnel}

As seções de medida foram plotadas em estereograma como projeções ciclográficas, juntamente com os eixos principais das elipses obtidas e ajustadas.

Caso as seções sejam ortogonais entre si e os eixos das elipses coincidam aproximadamente com suas intersecções, as direções principais já estão determinadas. As relações entre $\mathbf{X}: \mathbf{Y}: \mathbf{Z}$ são determinadas então pelas razões entre as elipsidades das seções de medida. Caso isto não ocorra, passa-se ao procedimento geral de determinação das direções principais, pela construção de Biot-Fresnel.

A determinação das direções principais de deformação pela construção de Biot-Fresnel consiste na determinação das duas seções circulares do elipsóide de deformação. No caso geral, existem apenas duas seções circulares, sendo a interseção entre elas o eixo $\mathbf{Y}$ (intermediário) do elipsóide, e as suas bissetrizes as direções $\mathbf{X}$ (maior) e $\mathbf{Z}$ (menor).

Nas seções de medida lançadas no diagrama, o valor do estiramento $S\left(\lambda^{1 / 2}\right.$ ou $\left.1+e\right)$ foi 
plotado de $10^{\circ} \mathrm{em} 10^{\circ}$.

Foram aqui adotadas as definições de elongação quadrática $(\lambda)$, elongação (e) e extensão ou estiramento $(\mathrm{S})$ a seguir:

$$
\lambda=\left(l_{1} / l_{0}\right)^{2} \quad e=\left(l_{1}-I_{0}\right) / I_{0} \quad S=l_{1} / l_{0}
$$

onde h é o comprimento de uma linha após a deformação, e b o seu comprimento inicial, antes da deformação.

Como em geral não são obtidas as elongações absolutas, mas sim razões de strain, $R_{S}=S_{1} / S_{2}=\left(\lambda_{1} / \lambda_{2}\right)^{1 / 2}$, das seções, atribui-se arbitrariamente $\lambda=1$ para uma das intersecções entre as seções (ou para uma das elongações principais menores). Os demais valores são obtidos segundo a relação:

$$
\lambda^{\prime}=\lambda_{1}^{\prime} \cos ^{2} \theta^{\prime}+\lambda_{2}^{\prime} \operatorname{sen}^{2} \theta^{\prime}
$$

onde $\lambda^{\prime}$ é elongação quadrática recíproca $\left(\lambda^{\prime}=1 / \lambda\right)$ de uma determinada linha, que faz um ângulo $\theta^{\prime}$ com a direção principal $\lambda_{1}$, (no estado deformado), e $\lambda_{1}^{\prime} \lambda_{2}^{\prime}$ são as elongações quadráticas recíprocas principais.

Esta técnica produz na projeção estereográfica um "mapa" das elongações nas várias direções, que já permite visualizar as áreas do diagrama onde podem estar localizadas as direções principais de deformação $\mathbf{X}$ e $\mathbf{Z}$. A determinação das seções circulares consiste então na localização de dois círculos máximos que interceptam as três seções de medida em pontos com o mesmo valor de elongação. Para isso é necessário checar sistematicamente os círculos máximos de todas as direções e mergulhos, até localizar as seções circulares.

\section{Determinação das razões entre as elongações principais.}

Para a determinação das razões entre os eixos principais $\mathbf{X}: \mathbf{Y}: \mathbf{Z}$ do elipsóide, preferiu-se adotar um procedimento algébrico.

Uma vez determinadas as três direções principais, têm-se também os três planos principais do elipsóide. Cada plano principal intercepta as três seções de medida. Portanto, em cada plano principal conhece-se a posição dos eixos principais e as elongações de três linhas (as interseções com as seções de medida). As elongações principais podem ser obtidas pela resolução do seguinte sistema:

$$
\begin{aligned}
& \lambda_{\mathrm{a}}^{\prime}=\lambda_{1}^{\prime} \cos ^{2} \theta_{\mathrm{a}}^{\prime}+\lambda_{2}^{\prime} \operatorname{sen}^{2} \theta_{\mathrm{a}}^{\prime} \\
& \lambda_{\mathrm{b}}^{\prime}=\lambda_{1}^{\prime} \cos ^{2} \theta_{\mathrm{b}}^{\prime}+\lambda_{2}^{\prime} \operatorname{sen}^{2} \theta_{\mathrm{b}}^{\prime}
\end{aligned}
$$

onde $\lambda_{\mathrm{a}}^{\prime}, \theta_{\mathrm{a}}^{\prime}, \lambda_{\mathrm{b}}^{\prime}, \theta_{\mathrm{b}}^{\prime}$ são respectivamente as elongações quadráticas recíprocas e os ângulos com a direção principal $\lambda_{1}$ de duas linhas $\mathbf{a}$ e $\mathbf{b}$, as quais podem ser duas das três interseções possíveis. Alguns testes com casos construídos mostraram que devem ser escolhidas 
as duas linhas com elongações e orientações as mais diferenciadas possível, para diminuir os erros.

\subsubsection{Discussão dos resultados}

a) Intensidade da deformação

Os resultados obtidos estão listados na tabela 4.1. As atitudes dos eixos principais obtidos estão representadas na figura 4.3. A figura 4.1 mostra também a orientação do eixo maior $\mathbf{X}$ de cada determinação de deformação finita, com sua localização em mapa e os valores de $R_{s}$ e $K$ obtidos. A figura 4.4 mostra um diagrama de Flinn modificado (Ramsay, 1967).
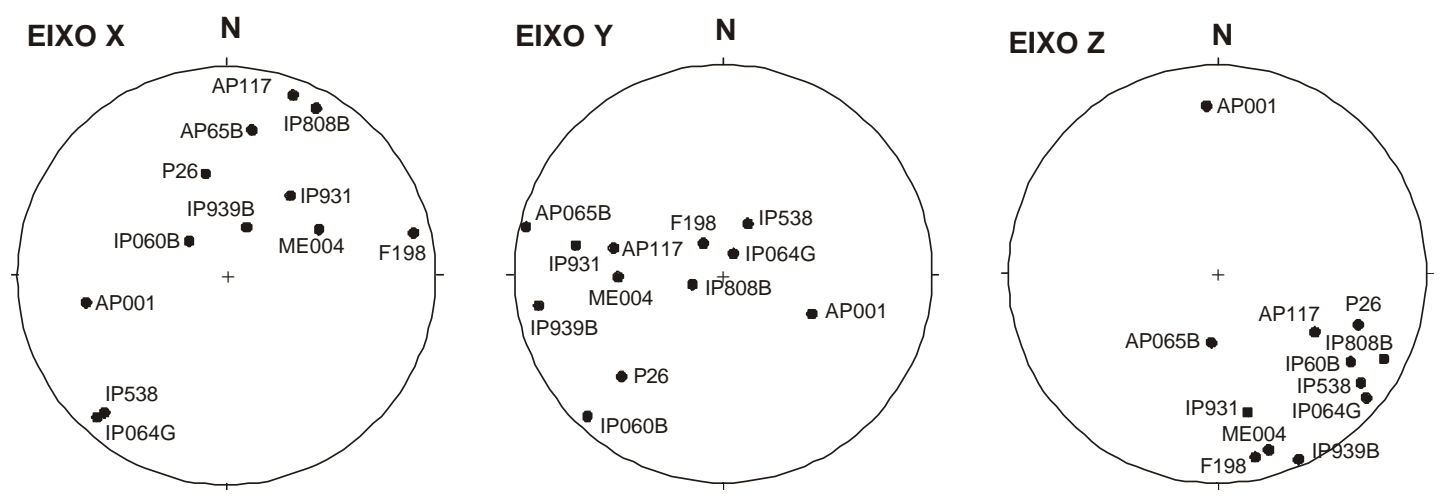

Figura 4.3 - Orientações dos eixos principais de deformação finita $(X, Y, Z)$ obtidas. As amostras IP071C, IP253B e IP928 apresentam razões de deformação $\left(R_{S}=S_{1} / S_{3}\right)$ muito baixas $\left(R_{S}<1,4\right)$, e por este motivo não foram mostradas (diagramas de Schmidt - Lambert, hemisfério inferior).

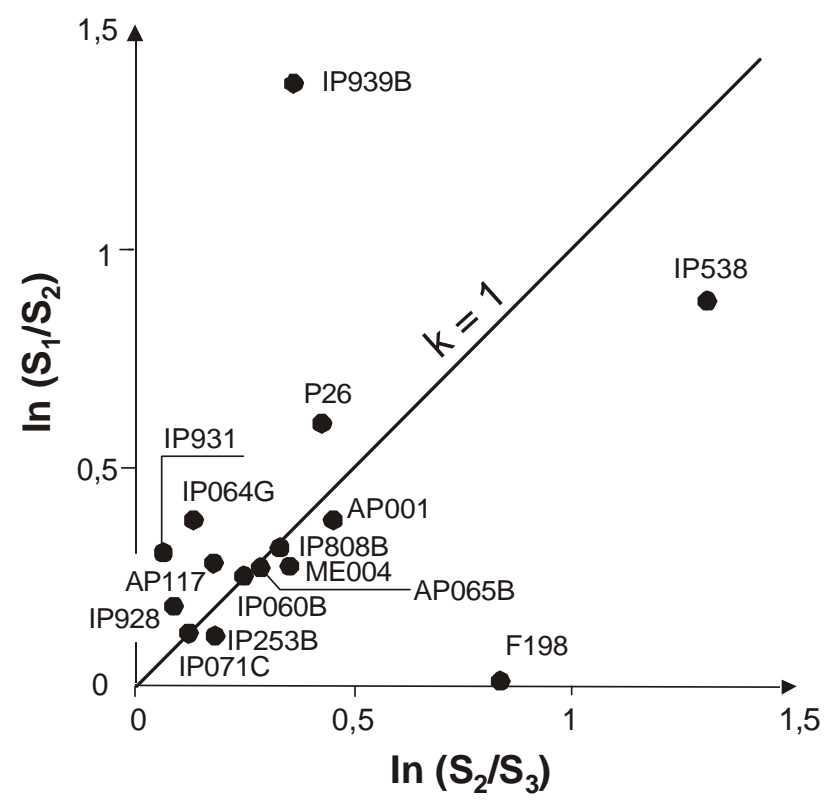

Figura 4.4 - Diagrama bilogarítmico das razões entre as extensões principais obtidas (Diagrama de Flinn, modificado). 
Em termos da deformação máxima sofrida (X/Z), nota-se que duas amostras (IP538, IP939) mostraram deformação alta (X/Z > 5). Três (IP071C, IP253B, IP928) mostraram deformação muito baixa $(\mathbf{X} / \mathbf{Z}<1,4)$. A maioria mostrou deformações baixas $(2>\mathbf{X} / \mathbf{Z}>1,4)$, e duas amostras (IP001, P26) apresentaram deformação média (5 $>\mathbf{X} / \mathbf{Z}>2$ ) (Figuras 4.1 e 4.4, Tabela 4.1).

Estes resultados confirmam a impressão qualitativa de que as rochas do Bloco Lajeado são de modo geral pouco ou muito pouco deformadas, a não ser próximo a zonas de cisalhamento (o caso das amostras AP001 e P26). Enquanto que no Bloco Ribeira as deformações são mais altas (amostras IP939B e IP538). A figura 4.1 mostra claramente este aspecto, principalmente os valores de deformação mais altos nas proximidades das zonas de cisalhamento da Figueira e do Carumbé.

À parte destas determinações completas da deformação finita, algumas indicações parciais confirmam aproximadamente a faixa de variação desses resultados.

Manchas elipsoidais milimétricas em filitos de Formação Iporanga, possivelmente devidas a óxido-redução sindiagenética, apresentam razões $\mathbf{X}: \mathbf{Y}: \mathbf{Z}$ de ordem 8:6:1. Manchas elipsoidais em mármores do Bloco Lajeado, junto ao Lineamento da Figueira, apresentam razões $\mathbf{X}: \mathbf{Y}: \mathbf{Z}$ de 14:5:1. Em nenhum dos casos foi possível obter amostras orientadas. Contudo, mostram que a deformação, junto às zonas de cisalhamento e nos metapelitos finos, pode ser maior do que nos pontos analisados.

Fiori (1997) analisando os conglomerados deformados da Formação Camarinha, próximos à Falha da Lancinha, a SW da presente área, obteve valores de $R_{\mathrm{s}}$ entre 1,8 e 2,4.

b) Forma dos elipsóides

No diagrama de Flinn (Figura 5), nota-se que a maior parte dos elipsóides obtidos aproxima-se do tipo com $k=1$. Três deles (IP939B, IP931 e IP064G) são fortemente prolatos (k>>1) e dois (IP538 e F198) são fortemente oblatos (k<<1).

Adotando-se como hipótese que na direção do eixo principal intermediário de deformação (Y) não tenha ocorrido deformação $(\lambda=1)$, a maior parte dos elipsóides corresponderia a deformação planar a volume constante, enquanto que os correspondentes às amostras IP939B, IP931 e IP064G apresentariam ganho apreciável de volume e, o associado às amostras IP538 e F198, perda de volume.

c) Orientação dos eixos principais

Com relação à orientação dos eixos principais, nota-se na figura 4.3 que a quase totalidade dos eixos $\mathbf{Z}$ é coerente com uma orientação do plano de máximo achatamento com direção NE e mergulhos fortes para NW, o que é concordante com a orientação média da xistosidade e clivagem ardosiana nessa área. A exceção é feita pelo ponto AP001, no flanco norte do Sinclinal 
do Calabouço, mas que é coerente com as estruturas locais. Deve-se atentar que as amostras IP928, IPO71C e IP253B, que não foram lançadas na figura 4, fugiram deste padrão. No entanto, correspondem àqueles valores muito baixos de deformação finita $(\mathbf{X} / \mathbf{Z}<1,4)$. Espera-se nestes casos um erro ou indeterminação grande das direções principais, já que o elipsóide aproxima-se de uma esfera.

Em termos de orientação do eixo $\mathbf{X}$, nota-se nas figuras 4.1 e 4.3 que, desprezando-se as amostras já citadas com baixa razão de deformação, a maior parte dos eixos $X$ mostra uma tendência de orientação NE/SW sub-horizontal, inclusive aquelas situadas na porção central do Bloco do Lajeado. São exceção a amostra AP001, discutida acima, e as amostras situadas na zona de influência dos lineamentos da Figueira e de Agudos Grandes (IP060B, P26, IP939), as quais tendem a mostrar eixos $\mathbf{X}$ com forte caimento e/ou com orientação para NW, configurando uma posição de mergulho a oblíqua com relação à atitude dessas zonas de cisalhamento. Isto reforça o caráter de movimentação inversa a oblíqua dessas estruturas, que por sua vez são defletidas com sentido destral pelo Lineamento Ribeira, e portanto devem ser algo mais antigas que este.

Fiori (op. cit.) também obteve eixos $\mathbf{X}$ subhorizontais, com direções em torno de N70-80E, para os conglomerados da Formação Camarinha, junto ao Lineamento Lancinha, não tendo por outro lado obtido atitudes com forte mergulho. Possivelmente esta diferença se deve ao fato de Fiori (op. cit.) ter trabalhado nas proximidades do Lineamento Lancinha, não ocorrendo em sua área de estudo estruturas com orientação mais oblíqua à regional e movimentação inversa, tais como o Lineamento Figueira.

d) Análise de amostra de metabrecha

As determinações feitas com a amostra IP939B merecem alguma análise adicional. Tratase de uma brecha de matriz metapelítica com fragmentos de metassiltitos e metarritmitos. Nela foram aplicados os métodos de orientação preferencial, $R_{F} / \phi$ e média harmônica. Como 0 contraste de ductilidade entre a matriz e os fragmentos deve ser baixo, já que são do mesmo material, e uma dimensão (comprimento) é muito maior do que a outra (largura), tentou-se a aplicação do método da orientação preferencial (Ramsay \& Huber, 1983). Análise de orientação dos fragmentos foi feita através de histogramas de orientação da dimensão maior dos fragmentos versus freqüência (figura 4.5), comparados com o gráfico padrão de curvas com diferentes razões de deformação $\left(R_{S}\right)$. Esta comparação forneceu os resultados da tabela 4.3. 

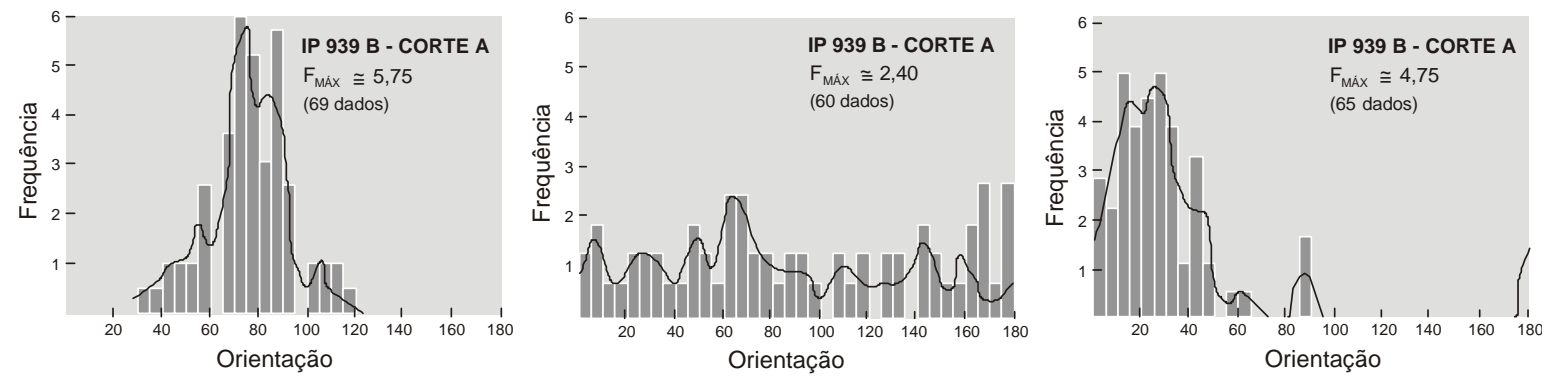

Figura 4.5 - Histogramas da orientação de fragmentos ripiformes da brecha de Iporanga, em três cortes da amostra IP939B.

\begin{tabular}{|c|c|c|c|}
\hline Corte A & Corte B & Corte C & Método \\
\hline 4.75 & 3.79 & 4.10 & média harmônica \\
\hline 5.75 & 2.40 & 4.75 & orientação preferencial \\
\hline 5.00 & 2.40 & 4.60 & $\mathrm{R}_{\mathrm{F}} / \phi$ \\
\hline
\end{tabular}

Tabela 4.3 - Valores de $R_{s}$ obtidos para a amostra IP-939B por vários métodos, para os três cortes analisados.

A aplicação do método $R_{F} / \phi$ mostrou resultados muito semelhantes, como se vê na figura 4.6 e tabela 4.3. A razão de deformação $\left(R_{S}\right)$ foi obtida através dos gráficos padrão fornecidos por Lisle (1985). As nuvens de pontos obtidas são aproximadamente simétricas, com relação à linha de orientação $(\phi)$ média, evidenciando que não havia orientação preferencial de natureza prédeformacional dos fragmentos (Ramsay, 1967; Lisle, 1985).
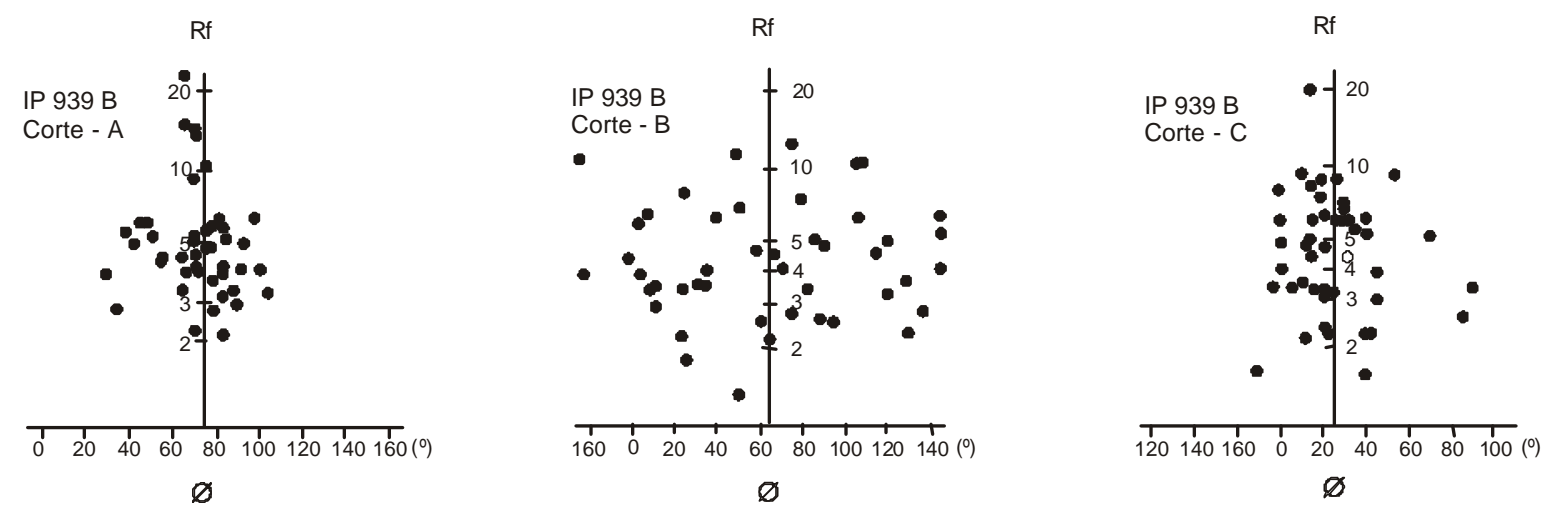

Figura 4.6 - Gráficos $R_{F}$ versus $\phi$ de três cortes da amostra IP939B (Brecha de Iporanga). 
Já o método da média harmônica (Ramsay \& Huber, 1983) forneceu resultados discrepantes para a seção menos deformada, provavelmente devido ao formato original extremamente longilíneo dos fragmentos.

\subsubsection{Tensores de deformação recalculados para as orientações geográficas}

Como um dos objetivos da obtenção de dados de strain é realizar sua integração sobre uma determinada região, é interessante referir-se o tensor de extensão para as orientações geográficas. Por exemplo, adotaremos aqui o eixo de referência $x_{1}$ no sentido positivo orientado para o leste, o $x_{2}$ para o norte, e o $x_{3}$ vertical para cima.

Na prática, dispondo-se dos valores principais de extensão e suas orientações, obtidas a partir de medidas de strain, pode-se montar uma matriz $\mathbf{V}_{\mathbf{0}}$ com os valores principais de extensão na diagonal principal. Esta matriz representa o tensor de extensão no estado deformado, porém com relação a um sistema de referência cujos eixos são os próprios eixos principais do elipsóide.

$$
\mathbf{V}_{\mathbf{0}}=\left[\begin{array}{ccc}
\mathrm{S}_{1} & 0 & 0 \\
0 & \mathrm{~S}_{2} & 0 \\
0 & 0 & \mathrm{~S}_{3}
\end{array}\right]
$$

Para referir-se as extensões para o sistema geográfico, é necessário fazer-se uma rotação dos eixos de referência (transformação de coordenadas para tensores de segunda ordem), na qual usar-se-á as orientações dos eixos principais de deformação obtidos, descritas como cossenos diretores com relação ao sistema geográfico.

Os cossenos diretores de uma linha podem ser calculados a partir do seu azimute e de seu caimento (plunge), no sistema de referência aqui adotado, pelas seguintes relações:

$$
\begin{gathered}
\mathrm{I}=\cos (\text { plunge }) \cdot \operatorname{sen}(\text { azimute }) \\
\mathrm{m}=\cos (\text { plunge }) \cdot \cos (\text { azimute) } \\
\mathrm{n}=\operatorname{sen}(\text { plunge })
\end{gathered}
$$

Deve-se então calcular e montar uma matriz de transformação com os cossenos diretores $(I, m, n)$ das direções principais do elipsóide de deformação obtidas por medidas strain,:

$$
\mathbf{A}=\left[\begin{array}{ccc}
\mathrm{l}_{1} & \mathrm{l}_{2} & \mathrm{l}_{3} \\
\mathrm{~m}_{1} & \mathrm{~m}_{2} & \mathrm{~m}_{3} \\
\mathrm{n}_{1} & \mathrm{n}_{2} & \mathrm{n}_{3}
\end{array}\right]
$$


onde os subscritos indicam os eixos principais de deformação 1, 2, 3.

$\mathrm{O}$ tensor de extensão $\mathbf{V}_{\mathbf{G}}$ referido ao sistema geográfico será, pela regra da transformação de tensores de segunda ordem (Nye, 1957):

$$
\mathbf{V}_{\mathrm{G}}=\mathbf{A} \cdot \mathbf{V}_{\mathbf{O}} \cdot \mathbf{A}^{\top}
$$

O qual terá os mesmos autovalores (extensões principais) que $\mathbf{V}_{\mathbf{o}}$, e seus autovetores darão as orientações dos eixos principais de deformação com relação às direções geográficas.

Na tabela 4.4 mostra-se um exemplo dos resultados da aplicação desses cálculos, para uma das amostras analisadas, realizados com o programa MathCad.

\begin{tabular}{|c|c|c|c|}
\hline PONTO & AP001 & & \\
\hline \multicolumn{4}{|c|}{$\begin{array}{l}\text { Tensor de Extensão referido aos eixos principais } \\
\text { de deformação }\left(\mathbf{V}_{\mathbf{O}}\right)\end{array}$} \\
\hline $\mathrm{X}$ & 1.46 & 0 & 0 \\
\hline $\mathrm{Y}$ & 0 & 1 & 0 \\
\hline $\bar{Z}$ & 0 & 0 & 0.64 \\
\hline \multicolumn{4}{|c|}{$\begin{array}{l}\text { Atitudes dos eixos principais de deformação } \\
\text { finita }\end{array}$} \\
\hline & $\mathrm{X}$ & $\mathrm{Y}$ & Z \\
\hline X Rumo & 258 & 114 & 359 \\
\hline Merg & 32 & 52 & 19 \\
\hline \multicolumn{4}{|c|}{$\begin{array}{l}\text { Matriz de transformação para sistema geográfico } \\
\text { (A) }\end{array}$} \\
\hline & $\mathrm{X}$ & \begin{tabular}{l|}
$\mathrm{Y}$ \\
\end{tabular} & $\mathrm{Z}$ \\
\hline 1 & -0.82952 & 0.562435 & -0.0165 \\
\hline $\mathrm{m}$ & -0.17632 & -0.25041 & 0.945375 \\
\hline \multirow[t]{2}{*}{$\mathrm{n}$} & -0.52992 & -0.78801 & -0.32557 \\
\hline & 1 & 1 & 1 \\
\hline \multicolumn{4}{|c|}{$\begin{array}{l}\text { Tensor de Extensão referidos para o sistema } \\
\text { geográfico }\left(\mathbf{V}_{\mathbf{G}}\right)\end{array}$} \\
\hline & 1.321 & 0.063 & 0.202 \\
\hline & 0.063 & 0.68 & 0.137 \\
\hline & 0.202 & 0.137 & 1.099 \\
\hline
\end{tabular}

Tabela 4.4 Resultados para o cálculo do tensor de extensão para o ponto AP001.

A partir dos tensores de extensão assim referidos, podem ser feitas diversas outras manipulações, como cálculos da extensão numa determinada direção, da elipse de deformação para um plano determinado (por ex., o plano horizontal, ou o plano vertical NS).

Como exemplo calculou-se as extensões horizontais ao longo da direção NW, de modo que se pudesse comparar com os valores obtidos a partir do perfil geológico.

A elongação quadrática recíproca de uma linha pode ser obtida pela equação (2.11), do capítulo 2, e o tensor $\mathbf{c}$ da equação (2.20), rotacionando a matriz c do mesmo modo como 
mostrado acima para a matriz $\mathbf{V}$. A extensão é então obtida pela raíz quadrada do inverso da elongação quadrática recíproca.

\begin{tabular}{|c|c|c|c|c|c|c|c|c|}
\hline PONTO & AP001 & AP65B & AP117 & IP060B & $\overline{I P 064 G}$ & $\overline{I P 071 C}$ & IP253B & IP808B \\
\hline unidade & $\begin{array}{l}\text { S.Boa } \\
\text { Vista }\end{array}$ & $\begin{array}{l}\text { S.Boa } \\
\text { Vista }\end{array}$ & $\begin{array}{l}\text { S.Boa } \\
\text { Vista }\end{array}$ & Betari & Betari & $\begin{array}{l}\text { B. da } \\
\text { Serra }\end{array}$ & $\begin{array}{l}\text { S.Boa } \\
\text { Vista }\end{array}$ & $\begin{array}{l}\text { B. da } \\
\text { Serra }\end{array}$ \\
\hline Fv $\left(S_{2}=1\right)$ & 0.934 & 0.983 & 1.096 & 1.006 & 1.285 & 0.994 & 0.93 & 0.986 \\
\hline$S 135 / 00$ & 0.801 & 1.001 & 0.924 & 0.813 & 0.881 & 0.992 & 1.035 & 0.745 \\
\hline PONTO & IP928 & IP931 & ME004 & P26 & IP939B & \begin{tabular}{|l|} 
IP538 \\
\end{tabular} & F198 & \\
\hline unidade & $\begin{array}{l}\text { B. da } \\
\text { Serra }\end{array}$ & M. Furnas & Gorutuba & $\begin{array}{l}\text { B. da } \\
\text { Serra }\end{array}$ & Iporanga & Ribeira & Ribeira & \\
\hline Fv $\left(S_{2}=1\right)$ & 1.104 & 1.256 & 0.924 & 1.183 & 2.754 & 0.651 & 0.435 & \\
\hline$S 135 / 00$ & 1.067 & 0.958 & 0.764 & 0.753 & 0.724 & 0.275 & 0.502 & \\
\hline
\end{tabular}

Tabela 4.5 - Resultados do cálculo da extensão de uma linha com orientação no estado deformado NW horizontal (135/00). e variação de volume $\left(F_{v}\right)$ admitindo-se S2 = 1 .

Analisando-se o perfil geológico NW em 1:50.000 através da área (Campanha, 1991) no tocante ao comprimento das camadas dobradas versus o comprimento do perfil, para várias unidades estratigráficas, e não considerando a deformação interna das camadas, foram obtidos valores de encurtamento mostrados na Tabela 4.6. Estes valores são compatíveis com as extensões obtidas a partir de análise de strain em amostras dessas unidades (Tabela 4.5).

\begin{tabular}{|l|c|c|c|c|c||}
\hline & $1_{1}(\mathrm{~km})$ & $1_{0}(\mathrm{~km})$ & $\mathrm{S}=1_{1} / 1_{0}$ & $\lambda=\left(1_{1} / 1_{0}\right)^{2}$ & $\mathrm{e}=\left(1_{1}-1_{0}\right) / 1_{0}$ \\
\hline Subgrupo Lajeado & & & & & \\
\hline Fm. Betari & 9.4 & 12.2 & 0.77 & 0.59 & -0.23 \\
\hline Fm. Bairro da Serra & 10.2 & 14.0 & 0.73 & 0.53 & -0.27 \\
\hline Fm. Mina de Furnas & 18.5 & 22.6 & 0.82 & 0.67 & -0.18 \\
\hline Subgrupo Ribeira & 7.5 & 22.1 & 0.34 & 0.11 & -0.66 \\
\hline
\end{tabular}

Tabela 4.6 - Extensões das unidades estratigráficas medidas segundo perfil NW.

Algumas considerações podem ser feitas sobre esses procedimentos.

Uma primeira é que estes procedimentos são necessários porque está se trabalhando com deformações em três dimensões, tendo ocorrido de um modo geral fluxo em direções perpendiculares ou oblíquas à seção que se deseja analisar (ou seja, não é uma deformação plana). Os mesmos resultados poderiam também ser obtidos com o círculo de Mohr para deformação finita em 3D, ou pela utilização da equação (2.21). Porém essa construção gráfica não é tão simples como no caso de $2 \mathrm{D}$, e as direções são referidas com relação aos eixos 
principais de deformação, sendo necessário depois calcular as atitudes com relação ao sistema geográfico (com um estereograma, por exemplo).

Outro ponto a ressaltar é que os métodos empregados para a análise de strain não determinam em geral as extensões absolutas, mas sim razões de strain. Arbitrariamente, para facilitar os cálculos, tomamos $S_{2}=1$. Deste modo os componentes da matriz de extensão podem ser multiplicados por fator de escala, uma constante de valor em geral desconhecido, que chamaremos de $\mathrm{k}$.

$$
\text { k. }\left[\begin{array}{ccc}
S_{1} & 0 & 0 \\
0 & S_{2} & 0 \\
0 & 0 & S_{3}
\end{array}\right]
$$

Este fator produz uma variação de volume $k^{3}$. Todas as extensões calculadas para linhas também seriam multiplicadas por $\mathrm{k}$.

\subsection{Variação química e volumétrica de metabasitos afetados pelo Lineamento Ribeira}

\subsubsection{Introdução}

A mobilidade de elementos químicos e a variação de volume em rochas afetadas por zonas de cisalhamento ainda é uma questão pouco estudada. Porém esta potencialmente apresenta grandes implicações no fluxo de fluidos e mineralizações associadas a zonas de cisalhamento.

O modelo clássico de variação de strain em zonas de cisalhamento privilegia o cisalhamento simples. Ou, no caso de diversos modelos de transpressão, combinações de cisalhamento simples e puro. Sendo o cisalhamento simples e o cisalhamento puro deformações planas, a volume constante, supostamente estariam vinculados a transformações mineralógicas isoquímicas.

Porém, já no trabalho clássico de Ramsay \& Graham (1970) argumenta-se por considerações baseadas nas equações de compatibilidade de strain, que em zonas planares de deformação intensa, apenas alguns campos de deformação são possíveis, a saber: (1) cisalhamento simples heterogêneo, (2) variação de volume heterogênea, e (3) deformação homogênea afetando a banda de deformação e paredes. Particularmente, não seria possível geometricamente ocorrer cisalhamento puro heterogêneo. Mesmo que cisalhamento puro homogêneo ocorra confinado à banda de deformação, teria que ser limitado por superfícies de descontinuidades junto às paredes da banda de deformação. 
Então a explicação para a ocorrência de deformação coaxial em bandas de deformação e achatamento (transpressão) pode basear-se na ocorrência de variação volumétrica perpendicular às paredes, que também pode ser descrita como achatamento (ou extensão) uniaxial perpendicular às paredes.

O problema é que os elipsóides de deformação finita gerados por deformações com ou sem variação de volume podem ter a mesma forma (mesmo K de Flinn). Uma abordagem que pode ser empregada é a determinação da variação volumétrica através de litogeoquímica e a aplicação de equações de balanço volumétrico (Gresens, 1967; O’Hara \& Blackburn, 1989; Glazner \& Bartley, 1991; Mohanty \& Ramsay, 1994).

No presente caso foram estudados corpos de metabasitos afetados pelo Lineamento Ribeira, onde se tem o controle da rocha fora e dentro da zona de cisalhamento.

Estas litologias já foram estudadas petrografica e quimicamente por Campanha (1991) e Frascá et al. (1997), objetivando a inferência dos ambientes paleotectônicos da Faixa Ribeira. Porém na época utilizaram-se análises químicas somente para elementos maiores e alguns traços. Com vistas aos objetivos atuais, os metabasitos foram reamostrados, incluindo agora espécimes afetados por cisalhamento (milonitizados) e hidrotermalismo, que haviam sido evitados no estudo anterior. Foram realizadas análises químicas completas para elementos maiores (fusão ICP), traços e terras raras (fusão ICP/MS), no laboratório ActLabs (Canadá). Foram também determinados os pesos específicos (densidades) das amostras analisadas, que são utilizados no método de Gresens.

Dos resultados analíticos obtidos, foram desprezados os elementos $\mathrm{Be}, \mathrm{Ge}, \mathrm{Mo}, \mathrm{Ag}, \mathrm{In}, \mathrm{Sn}$, $\mathrm{Sb}, \mathrm{W}, \mathrm{TI}, \mathrm{e} \mathrm{Bi}$, por apresentarem teores abaixo do limiar de detecção em praticamente todas as amostras. A outras determinações isoladas, eventualmente abaixo do limite de detecção, foi atribuído o valor zero. Quando disponíveis simultaneamente determinações por ICP e ICP/MS (no caso dos elementos $\mathrm{Ba}, \mathrm{Y}, \mathrm{V}, \mathrm{Zr}$ e Sr), foi adotado o ICP/MS, por apresentar resultados mais constantes e coerentes com os padrões e duplicatas analisados (Anexo B). Os dados disponíveis anteriormente (Campanha, 1991) não foram utilizados por apresentarem discrepâncias para alguns elementos, quando comparados com amostras reanalisadas.

Os dados químicos, já fornecidos em planilha MS Excel, foram analisados utilizando os recursos desse pacote, mas também foram convertidos para o pacote estatístico MiniTab e para o programa NewPet, com recursos mais especializados. Considerando os objetivos deste estudo, os dados não foram normalizados para base anidra, já que o ganho/perda de voláteis também pode ser analisado pelas equações de balanço volumétrico e de massas.

Foi realizada análise multivariada de agrupamento das amostras, através do programa MiniTab, visando a definição de grupos de amostras homogêneos quimicamente. Este agrupamento mostrou-se coerente com o agrupamento baseado em critérios petrográficos obtidos no estudo de seções delgadas.

A distribuição geográfica dos resultados e agrupamentos é mostrada na Figura 4.7. 


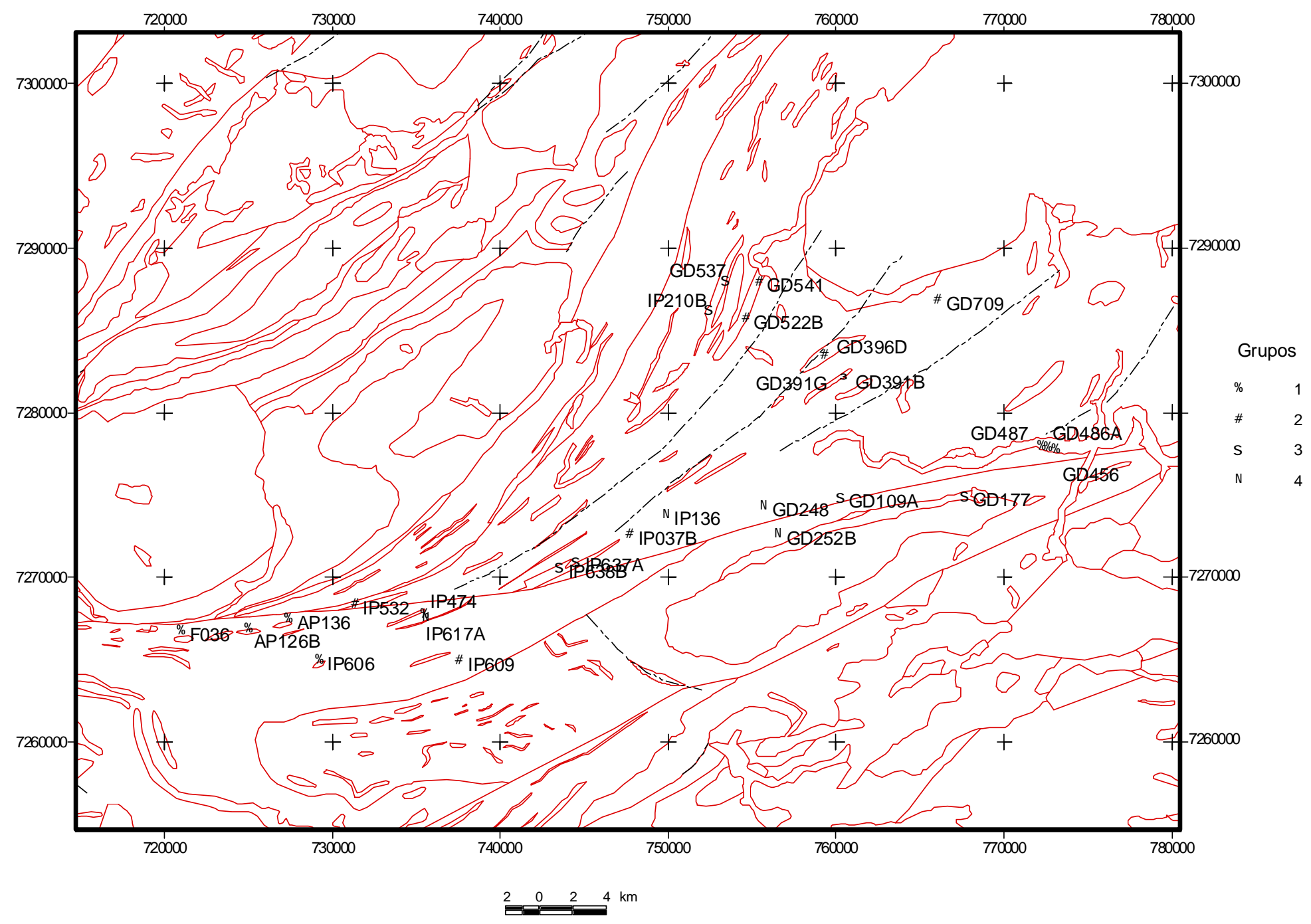

Figura 4.7 - Localização das amostras com análise química. 


\subsubsection{Método de Gresens}

O método de Gresens (Gresens, 1967, Potdevin, 1993) baseia-se em pressupostos bastante simples.

Considere-se uma rocha inicial $\mathrm{A}$ (protólito) a qual é transformada numa rocha $\mathrm{B}$ :

$$
A \rightarrow B
$$

Denominando como a a quantidade em gramas da rocha $A, \underline{b}$ a quantidade da rocha $B$, e $\underline{X}$ a quantidade de ganhos ou perdas em gramas, pode-se então escrever:

$$
\mathrm{a}+\mathrm{X}=\mathrm{b}
$$

Supondo-se a rocha com apenas dois componentes, 1 e 2 (podem ser elementos, óxidos, minerais, etc.), com as seguintes frações de peso:

$$
\begin{gathered}
C_{1 A} \text { - fração de peso do componente } 1 \text { em } A \\
C_{1 B} \text { - fração de peso do componente } 1 \text { em } B \\
C_{2 A} \text { - fração de peso do componente } 2 \text { em } A \\
C_{2 B} \text { - fração de peso do componente } 2 \text { em } B \\
X_{1} \text { - perda ou ganho em peso do componente } 1 \\
X_{2} \text { - perda ou ganho em peso do componente } 2
\end{gathered}
$$

pode-se então escrever:

$$
\begin{aligned}
& \text { b. } c_{1 B}-a \cdot c_{1 A}=X_{1} \\
& \text { b. } c_{2 B}-a \cdot c_{2 A}=X_{2}
\end{aligned}
$$

Considerando os volumes de $\mathrm{A}$ e $\mathrm{B}$ podemos definir um fator volumétrico como a razão entre o volume final e o inicial:

$$
\mathrm{F}_{\mathrm{V}}=\mathrm{V}_{\mathrm{B}} / \mathrm{V}_{\mathrm{A}}
$$

Considerando ainda as densidades de $\mathrm{A}$ e $\mathrm{B}$ :

$$
d_{A}=a / V_{A} \quad \text { e } d_{B}=b / V_{B}
$$

temos

$$
F_{V}=(b / a) \cdot\left(d_{A} / d_{B}\right)
$$

Como as densidades das rochas podem ser medidas, e as porcentagens em peso dos componentes podem ser obtidas por análises químicas (\% ou ppm, por ex.), temos três equações $(1,2$ e 3$)$ com cinco incógnitas $\left(F_{V}, a, b, X_{1}, X_{2}\right)$. Estas equações podem ser combinadas $e$ rearranjadas da seguinte forma:

$$
\begin{aligned}
& \text { a. }\left(F_{V \cdot}\left(d_{B} / d_{A}\right) \cdot c_{1 B}-c_{1 A}\right)=X_{1} \\
& \text { a. }\left(F_{V \cdot}\left(d_{B} / d_{A}\right) \cdot c_{2 B}-c_{2 A}\right)=X_{2}
\end{aligned}
$$

Dividindo ambos os termos das equações por a, tem-se os ganhos/perdas dos componentes por fração de peso de A:

$$
\begin{aligned}
& \mathrm{x}_{1}=\mathrm{X}_{1} / \mathrm{a} \\
& \mathrm{x}_{2}=\mathrm{X}_{2} / \mathrm{a}
\end{aligned}
$$


Todo o raciocínio pode ser extrapolado para mais componentes. Para n componentes, tem-se $n$ equações do tipo abaixo, com $n+1$ incógnitas:

$$
x_{n}=F_{V} \cdot\left(d_{B} / d_{A}\right) \cdot c_{n B}-c_{n A}
$$

Assumindo o conhecimento dos ganhos ou perdas de um determinado componente, eliminamos uma incógnita, podendo então calcular $F_{V}$ e as perdas/ganhos dos demais componentes.

Admitindo que um determinado componente i é imóvel $\left(\mathrm{x}_{\mathrm{i}}=0\right)$, pode-se obter $\mathrm{F}_{\mathrm{v}}$ :

$$
F_{v}=\left(c_{i A} / c_{i B}\right) \cdot\left(d_{A} / d_{B}\right)
$$

E os ganhos/perdas de um outro componente $n$ como:

$$
x_{n}=\left(c_{i A} / c_{i B}\right) \cdot c_{n B}-c_{n A}
$$

Uma técnica para determinar-se a faixa de valores razoável para $F_{V}$ consiste em, para todos os elementos, considerar-se a perda como zero, e a maior concentração de valores de $F_{V}$, principalmente para elementos tidos como imóveis, deve aproximar-se do valor correto.

\subsubsection{Caracterização petrográfica}

Sumário da caracterização petrográfica das amostras estudadas é mostrado na tabela 4.5. As características petrográficas exibidas pelas rochas metabásicas permitiram separá-las em cinco conjuntos:

a) hornblenda - actinolita anfibolitos

b) actinolita anfibolitos

c) diopsídio granofels

d) clorita - carbonato fels

e) plagioclásio-clorita xistos miloníticos

a) hornblenda - actinolita anfibolitos

Os hornblenda-actinolita anfibolitos constituem-se essencialmente por associações hornblenda e actinolita, com restos de plagioclásio, este quase totalmente saussuritizado (alterado em epídoto e carbonatos) e atualmente reconhecido pela forma tabular dos agregados de epídoto e restos locais preservados da alteração. Opacos, provavelmente titanomagnetita, envoltos por titanita, ocorrem subordinadamente. Quartzo e apatita são acessórios. Apesar do metamorfismo, estas rochas ainda preservam parcialmente o arranjo textural original subofítico a ofítico, semelhante ao de diabásios. Em geral apresentam estrutura isótropa e granulação fina, quase média. Apenas uma amostra, a F036, mostrou ser um anfibolito típico, com a associação metamórfica hornblenda + plagioclásio. 
b) actinolita anfibolitos

Compõem-se essencialmente de actinolita e epídoto (+ clorita e, localmente, biotita), os últimos em agregados ripiformes, sugerindo pseudomorfose sobre plagioclásios. Actinolita tende a ser fibrosa ou fibro-radiada. Opacos, titanita e algum quartzo ocorrem acessoriamente.

São em geral rochas com estrutura isótropa e granulação muito fina, conservando arranjo ofítico. Devem originalmente corresponder a basaltos ou diabásios finos. Diferenciam-se dos hornblenda anfibolitos pela predominância de actinolita, granulação mais fina e menor quantidade de opacos.

c) diopsídio granofels

Diopsídio granofels (amostras IP-637A e IP-638B), situados no Bairro da Ocorrência, são rochas de granulação fina compostas predominantemente de clinopiroxênio (diopsídio) em agregado granoblástico poligonal fino, onde se dispõem ripas milimétricas de prováveis cristais de plagioclásio, atualmente constituídas de albita, clinozoisita e alguma clorita magnesiana. Esta última, usualmente, não só envolve os cristais de diopsídio, mas também forma agregados arredondados, com alguma actinolita, que poderiam representar amígdalas. Megacristais (milimétricos) de diopsídio são raramente observados. Alguma albita e opacos leucoxenizados ocorrem acessoriamente. Estas rochas possivelmente derivam de basaltos.

d) clorita-carbonato granofels

Os clorita-carbonato granofels são rochas finas, em geral isótropas, por vezes brechadas e venuladas, de cor cinza a cinza-escuro esverdeado. Como minerais essenciais ocorrem carbonato, clorita, quartzo + plagioclásio, e ainda opacos. Na amostra IP-532 a ocorrência de raros cristais ripiformes de plagioclásio, associados a agregados microcristalinos de calcita em contato com agregados cloríticos, dão indícios de uma rocha originalmente básica que sofreu intensa alteração hidrotermal.

e) quartzo-plagioclásio-clorita xistos miloníticos

Os quartzo-plagioclásio-clorita xistos são rochas compostas predominantemente por clorita, possivelmente derivada da hidratação (retrometamorfismo) de minerais máficos durante a deformação. Subordinadamente há a presença de quartzo e plagioclásio. A textura é granolepidoblática, gerada por milonitização. 


\begin{tabular}{|c|c|c|c|c|c|}
\hline Grupo & Ponto & Litologia & Estrutura & Proveniência & $\begin{array}{r}\text { Observações } \\
\end{array}$ \\
\hline 1 & AP 126B & hornblenda anfibolito & foliada & sul do Lineamento Ribeira & fina a quase média, muitos opacos \\
\hline 1 & AP 136 & (hornblenda) - actinolita anfibolito & isótropa & sul do Lineamento Ribeira & fina a quase média, muitos opacos \\
\hline 1 & GD 456 & hornblenda-actinolita anfibolito & isótropa & norte do Lineamento Ribeira & fina a quase média, muitos opacos \\
\hline 1 & GD 486A & hornblenda-actinolita anfibolito & isótropa & Lineamento Ribeira & fina a quase média, muitos opacos \\
\hline 1 & IP 606 & (hornblenda) - actinolita anfibolito & isótropa & sul do Lineamento Ribeira & fina a quase média, muitos opacos \\
\hline 1 & GD 487 & andesina-calcita-quartzo-clorita xisto & milonítica & Lineamento Ribeira & fina a quase média, muitos opacos \\
\hline 1 & IP 474 & hornblenda anfibolito & pouco foliada & sul do Lineamento Ribeira & fina a quase média, muitos opacos \\
\hline 1 & F 036 & plagioclásio - hornblenda andibolito & foliada & Lineamento Ribeira & fina a quase média, muitos opacos \\
\hline 2 & GD 709 & plagioclásio-epidoto-clorita fels & isótropa & norte do Lineamento Ribeira & muito fina \\
\hline 2 & GD 522B & (hornblenda) - actinolita anfibolito & isótropa & norte do Lineamento Ribeira & muito fina \\
\hline 2 & GD 541 & actinolita anfibolito & isótropa & norte do Lineamento Ribeira & muito fina \\
\hline 2 & IP 609 & plagioclásio-quartzo-clorita xisto & milonítica & sul do Lineamento Ribeira & fina a quase média, muitos opacos \\
\hline 2 & GD $391 \mathrm{G}$ & hornblenda-actinolita anfibolito & isótropa & norte do Lineamento Ribeira & fina a quase média, muitos opacos \\
\hline 2 & IP 037B & actinolita anfibolito & pouco foliada & norte do Lineamento Ribeira & fina, muitos opacos, vênulas carbonáticas \\
\hline 2 & GD 396D & clorita-dolomita fels & isótropa & norte do Lineamento Ribeira & muito fina, vênulas carbonato e fx. milloníticas restritas \\
\hline 2 & IP 532 & clorita-carbonato-plagioclásio fels & isótropa & Lineamento Ribeira & muito fina, vênulas \\
\hline 3 & GD 177 & hornblenda-actinolita anfibolito & milonítica & Lineamento Ribeira & fina a média \\
\hline 3 & GD 537 & actinolita anfibolito & isótropa & norte do Lineamento Ribeira & muito fina \\
\hline 3 & IP 210B & actinolita anfibolito & isótropa & norte do Lineamento Ribeira & muito fina \\
\hline 3 & GD 109A & actinolita-hornblenda anfibolito & milonítica & Lineamento Ribeira & fina a média, muitos opacos \\
\hline 3 & GD 391B & actinolita anfibolito & isótropa & norte do Lineamento Ribeira & muito fina \\
\hline 3 & IP 637 & diopsídio granofels & isótropa & norte do Lineamento Ribeira & muito fina \\
\hline 3 & IP 638B & diopsídio granofels & isótropa & norte do Lineamento Ribeira & muito fina \\
\hline 4 & GD 248 & biotita-carbonato-plagioclásio fels & isótropa & norte do Lineamento Ribeira & muito fina, textura preservada \\
\hline 4 & GD 252B & epidoto-clorita-plagioclásio xisto & foliada / crenulada & sul (próximo) do Lin. Ribeira & fina \\
\hline 4 & IP $617 \mathrm{~A}$ & (biot. qz feldsp.) epidoto-clorita xisto & milonítica & sul (próximo) do Lin. Ribeira & fina a média \\
\hline 4 & IP 136 & clorita-actinolita-epidoto - biotita xisto & milonítica & norte do Lineamento Ribeira & fina, bem diferente das demais \\
\hline
\end{tabular}

Tabela 4.7 - Rochas metabásicas com análise litoquímica, ordenadas por grupos de similaridade química 


\subsubsection{Análise de agrupamento}

Todas as amostras analisadas química e petrograficamente foram submetidas à análise de agrupamento através do pacote estatístico MiniTab.

Foi feita análise de agrupamento hierárquica, através de dendograma (figura 4.8), com as variáveis padronizadas com o critério de distância de Pearson. Com o nível de corte de similaridade escolhido foram reconhecidos quatro grupos. Invertendo a classificação mostrada pelo dendograma das amostras F036 e GD709, as quais situam-se no limite entre os grupos 1 e 2, aumenta a coerência interna dos dois grupos. A localização das amostras por grupo é mostrada na figura 4.7.

Percebe-se que os grupos considerados apresentam discriminação muito boa nesses diagramas. A maior parte das amostras pode ser classificada como basaltos de filiação toleítica.

O grupo 1 é bastante homogêneo tanto petrográfica como quimicamente. Consiste em geral de hornblenda - actinolita anfibolitos, com abundantes opacos, granulação fina a quase média e estrutura isótropa. A amostra F036 seria o único anfibolito stricto sensu. As demais em geral apresentam hornblenda e actinolita coexistindo. A amostra GD487 distingue-se por ser um andesina-calcita-quartzo-clorita xisto milonítico, também com granulação fina a quase média e abundantes opacos. É notável a semelhança química entre as amostras AP-126B e AP-136, situadas nas proximidades do Lineamento Ribeira logo a sul deste, no extremo oeste da área, com as amostras GD-456, GD-486A e a amostra GD-487, estas três ultimas situadas nas proximidades do Lineamento Ribeira, logo ao norte deste, no extremo leste da área considerada. Se esta situação não for fortuita, mas devida ao deslocamento destral do Lineamento Ribeira, terse-ia um rejeito de 40-50 km, compatível com estimativas por outros métodos (item 4.3 adiante).

Por critérios químicos, as amostras do grupo 1 seriam basaltos, com exceção da GD487, um picro-basalto . São todas toleíticas, relativamente diferenciadas, situando-se no campo dos basaltos intraplacas ou MORB.

O grupo 2 ocorre ao norte do Lineamento Ribeira (com exceção da amostra IP609) e mostra características químicas e petrográficas intermediárias entre os grupos 1 e 3 . Inclui actinolita anfibolitos típicos da área ao norte do Lineamento Ribeira, isótropos e com granulação muito fina (GD522B, GD541, IP037, esta última com vênulas carbonáticas), e clorita-carbonato granofels, que são rochas isótropas, muito finas, venuladas e brechadas por vezes (GD709, GD396D, IP532). A amostra GD391G (um hornblenda-actinolita anfibolito) mostrou hornblenda coexistindo com actinolita. A IP609 é um plagioclásio-quartzo-clorita xisto milonítico. 


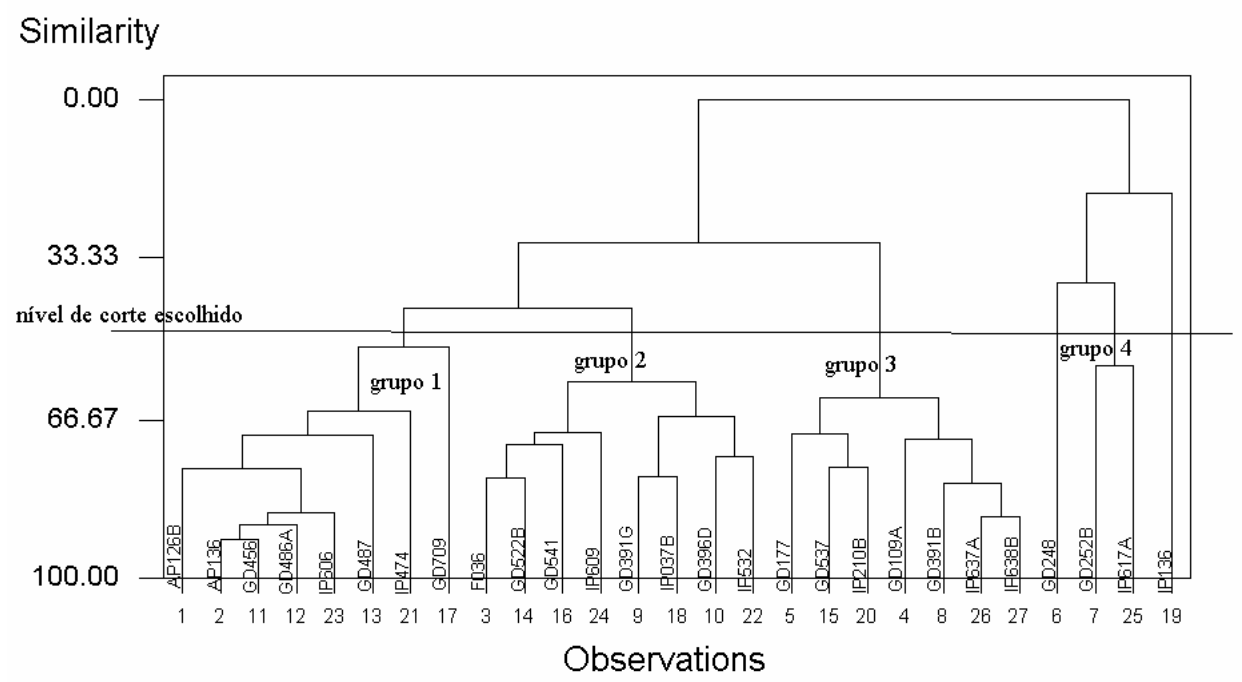

Figura 4.8-Dendograma

Em termos químicos as amostras do grupo 2 correspondem a basaltos, com exceção da F036, um basalto andesítico, e a IP532, um picro-basalto no limite com os basaltos. São todas de tendência toleítica, similares a basaltos de MORB ou arco de ilhas.

O grupo 3 inclui tipicamente actinolita anfibolitos (GD537, IP210B, GD391B) e diopsídio granofels (IP637, IP638B), com estrutura isótropa e granulação muito fina. Estas rochas ocorrem no bloco a norte do lineamento Ribeira e mostram forte homogeneidade petrográfica e química. As amostras GD177 e GD109A foram a elas agrupadas por similaridade química, mas constituem de fato actinolita-hornblenda anfibolitos miloníticos situados nas proximidades do Lineamento Ribeira. Quimicamente são todos correlatos a basaltos toleíticos, pouco diferenciados, similares a basaltos de arcos de ilhas imaturos.

O grupo 4 reúne as amostras que se mostraram mais discrepantes (na verdade, um "não grupo"). A GD248 é um biotita-carbonato-plágioclasio granofels, com estrutura isótropa, granulação muito fina e textura ígnea preservada. No diagrama de Le Maitre situa-se entre um traquiandesito basáltico e um fono-tefrito. A GD252B é um epídoto - clorita - plagioclásio xisto, correspondendo quimicamente a um basalto toleítico. As amostras IP617A e IP136 são variedades de biotita-epidoto-clorita xistos miloníticos, sendo a IP136 a mais dissimilar com relação às demais. Estas duas últimas correspondem quimicamente a andesitos. São todas quimicamente mais diferenciadas, com tendência cálcio-alcalina e no campo dos "basaltos" intraplacas. Porém são mais provavelmente rochas fortemente alteradas metassomaticamente e/ou por deformação. 
Uma vez estabelecidos os grupos de amostras similares, procurou-se comparar amostras com estruturas miloníticas e isótropas através do método de Gresens, visando determinar as variações volumétricas e o fluxo de elementos, ou mesmo avaliar se os diferentes grupos poderiam ser originados por variação composicional durante deformação e metamorfismo não isoquímico.

Como as amostras têm que ser comparadas duas a duas, foram escolhidos os seguintes casos:

- grupo 1: amostras GD486A (isótropa) e GD487 (milonítica);

- grupo 2: média das amostras isótropas com a IP609 (milonítica);

- grupo 2: GD541 (isótropa) com IP532 (brechada e venulada);

- grupo 3: média das amostras isótropas com a média das amostras GD109 e GD177 (miloníticas);

- média de todas amostras isótropas com todas amostras miloníticas.

Os resultados estão dispostos nas tabelas Anexo C e nas figuras de 4.9 a 4.13.

De um modo geral tomou-se o $\mathrm{TiO}_{2}$ como componente imóvel, o que produziu variações volumétricas $\left(F_{\mathrm{V}}\right)$ próximas às modas (valores mais freqüentes) de $F_{\mathrm{V}}$, quando calculadas considerando cada componente por vez como imóvel. Exceto para o grupo 3, onde considerou-se que o Ítrio fornecia um valor de $F_{V}$ mais próximo à moda geral.

Assim, comparando-se amostras isótropas com miloníticas, obteve-se para o grupo 1 um $F_{V}=0,87$, para o grupo 2 um $F_{V}=0,79$, para o grupo 3 um $F_{V}=0,81$ e para uma média geral das amostras $\mathrm{FV}=0$,84. Desta forma, pode-se concluir que o processo de milonitização dessas rochas esteve associado, em média, a uma perda de volume de 13 a $21 \%$.

Por outro lado, a comparação dentro do grupo 2 de uma amostra isótropa (GD541) e uma brechada e venulada (clorita-carbonato fels, IP532) mostrou um $F_{V}=1,25$, sugerindo um acréscimo de volume de $25 \%$.

O balanço de massas, melhor ilustrado através das figuras de 4.9 a 4.13 mostra fluxos de elementos coerentes nestes casos estudados. Para os elementos maiores teríamos as perdas mais significativas, respectivamente para $\mathrm{K}_{2} \mathrm{O}(\sim 80 \%), \mathrm{CaO}, \mathrm{MgO}, \mathrm{MnO}, \mathrm{Al}_{2} \mathrm{O} 3$ e $\mathrm{SiO}_{2}$, bem como ganhos significativos de voláteis e em alguns casos de $\mathrm{Na}_{2} \mathrm{O}$ e $\mathrm{P}_{2} \mathrm{O} 5$. Para os elementos menores teriam ocorrido perdas significativas de $\mathrm{As}, \mathrm{Rb}, \mathrm{Sr}, \mathrm{Ba}, \mathrm{Sc}, \mathrm{V}, \mathrm{Cr}$, Co, $\mathrm{Ni}, \mathrm{Cu}$, e ganho de $\mathrm{Cs}, \mathrm{Zr}$ e Zn. Há ganho em terras raras leves e perda em terras raras pesados.

É interessante notar que a substancial perda de $\mathrm{K}$ nas rochas miloníticas é detectada nos levantamentos aerogamaespectrométricos, onde as grandes zonas de cisalhamento da região são assinaladas por anomalias negativas lineares e estreitas desse elemento.

Também é importante notar que os processos de milonitização estariam associados a enriquecimento dos elementos imóveis (por perda dos móveis) e produzindo rochas aparentemente mais "diferenciadas". 
Ti imóvel - perdas / ganhos relativos

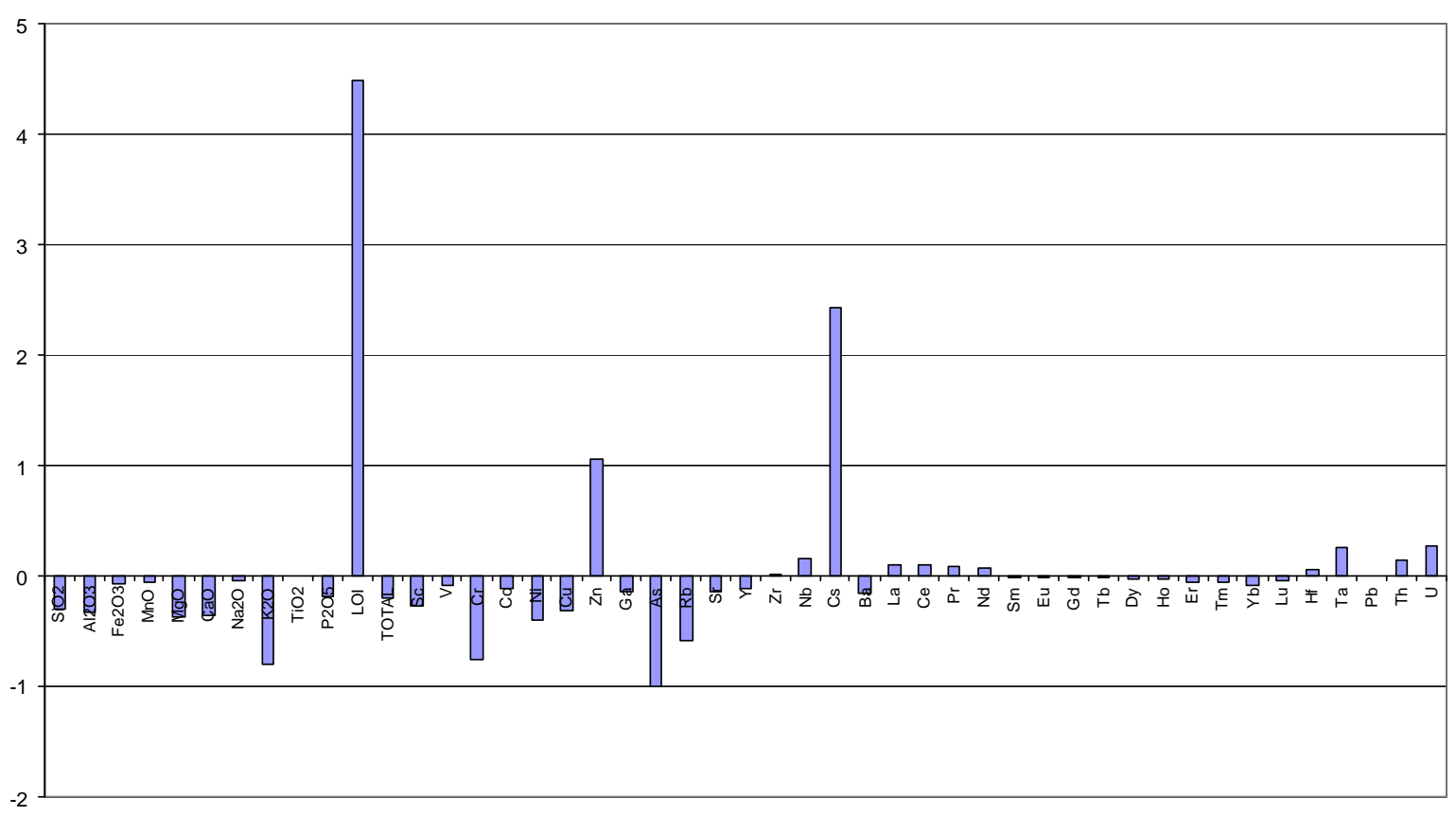

Figura 4.9 - Balanço de perdas e ganhos de componentes entre as amostras GD486A e GD487 (grupo 1). Cálculos considerando TiO2 imóvel, e ganhos/perdas relativos à massa inicial de cada componente.

Ti imóvel - perdas / ganhos relativos

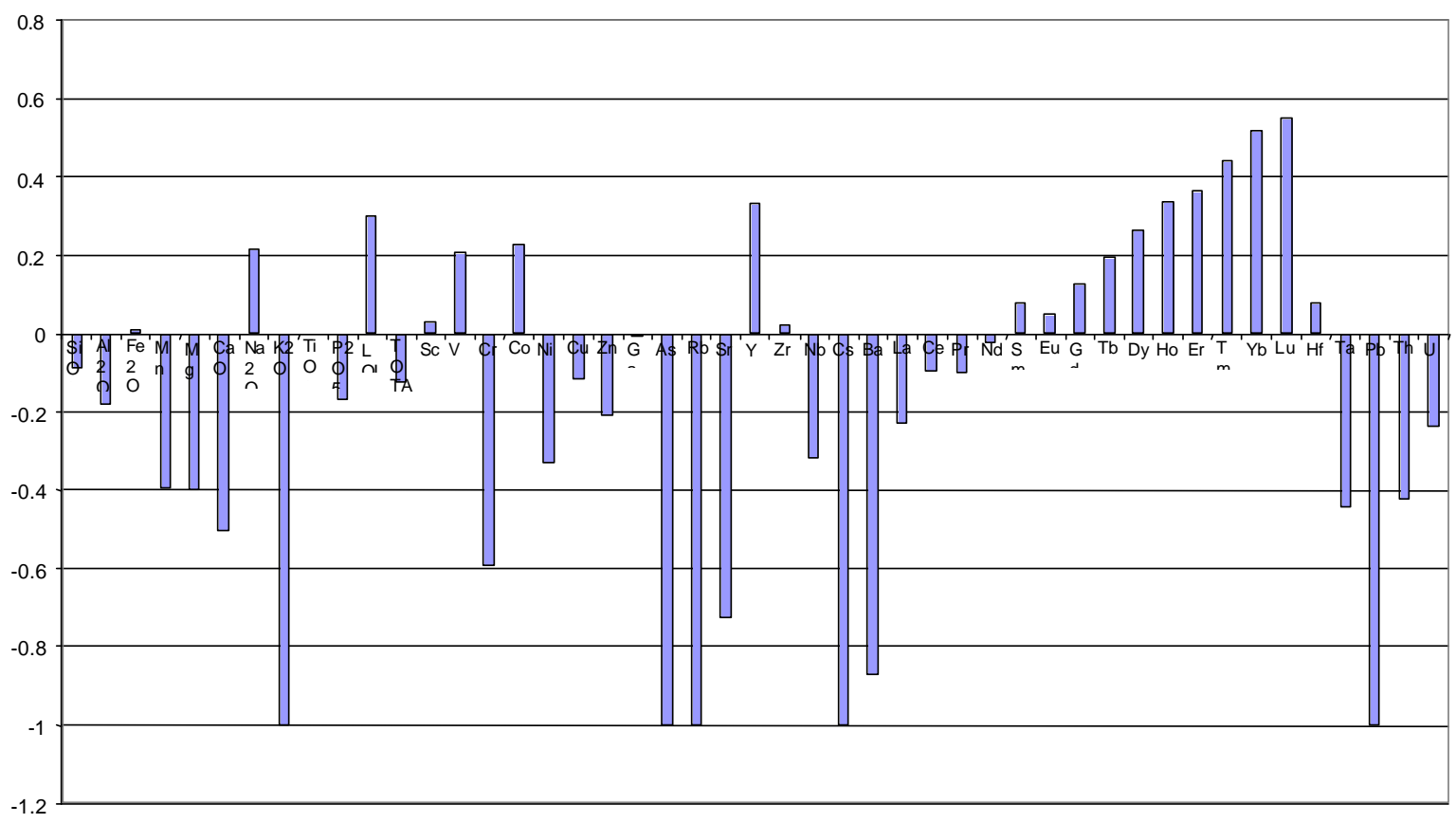

Figura 4.10 - Balanço de perdas e ganhos de componentes entre a amostra IP609 e a média de amostras isótropas do grupo 2. Cálculos considerando TiO2 imóvel, e ganhos/perdas relativos à massa inicial de cada compomente. 
Ti imóvel - perdas / ganhos relativos

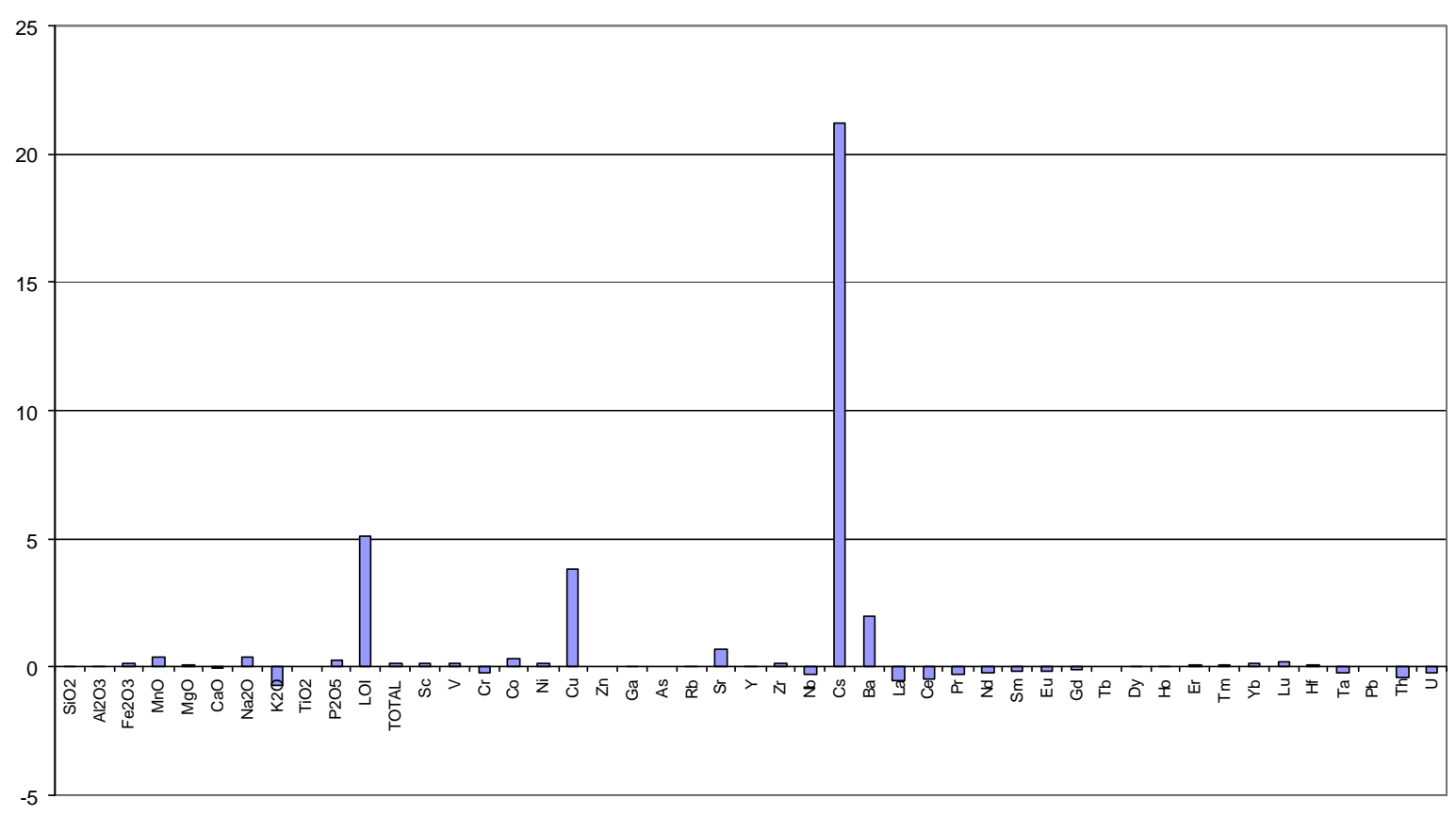

Figura 4.11 - Balanço de perdas e ganhos de componentes entre as amostras GD541 e GD532 (grupo 2). Cálculos considerando TiO2 imóvel, e ganhos/perdas relativos à massa inicial de cada compomente

Y imóvel - perdas / ganhos relativos

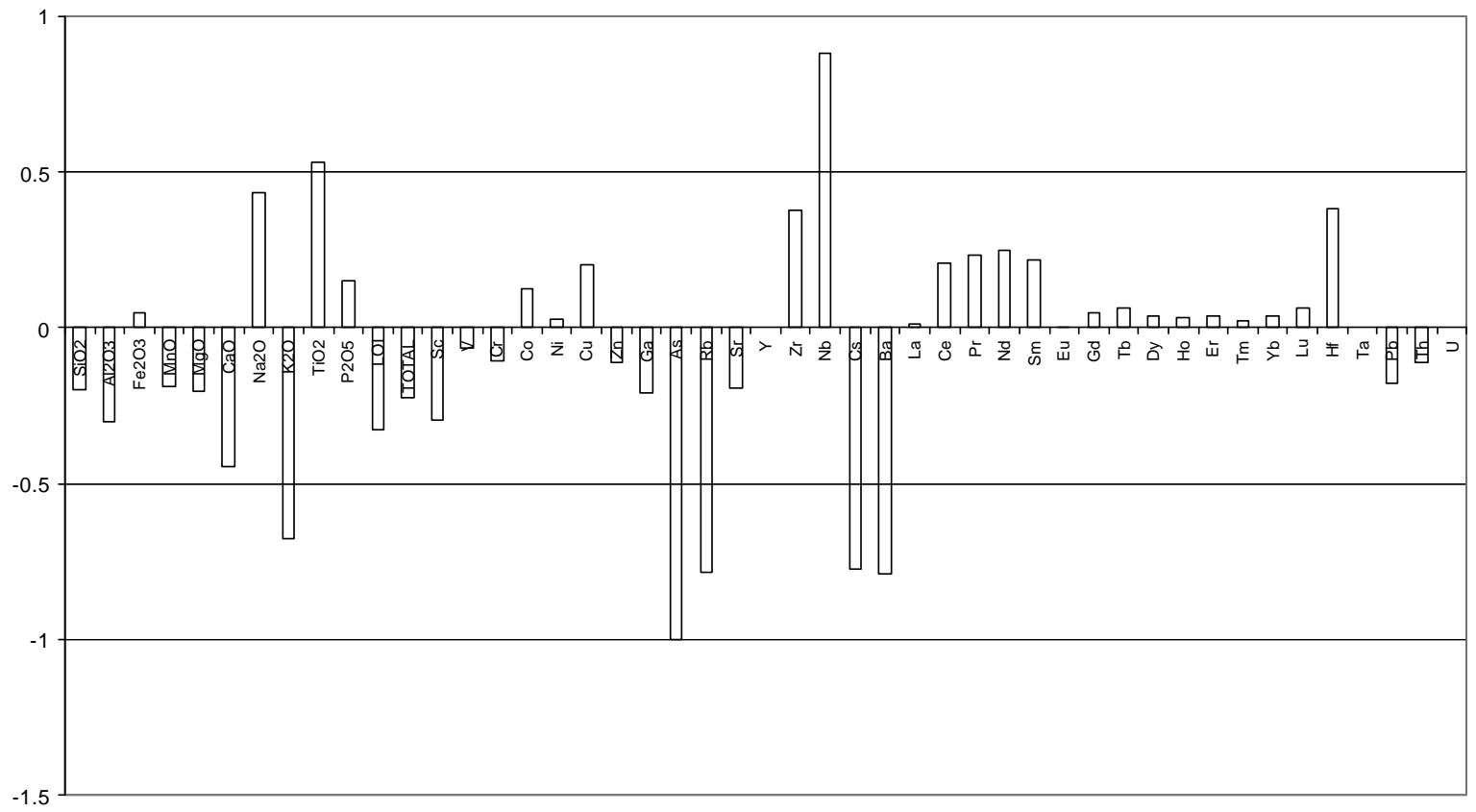

Figura 4.12 - Balanço de perdas e ganhos de componentes entre a média das amostras GD109 e GD177, e a média de amostras isótropas do grupo 3. Cálculos considerando Y imóvel, e ganhos/perdas relativos à massa inicial de cada compomente. 
Ti imóvel - perdas / ganhos relativos

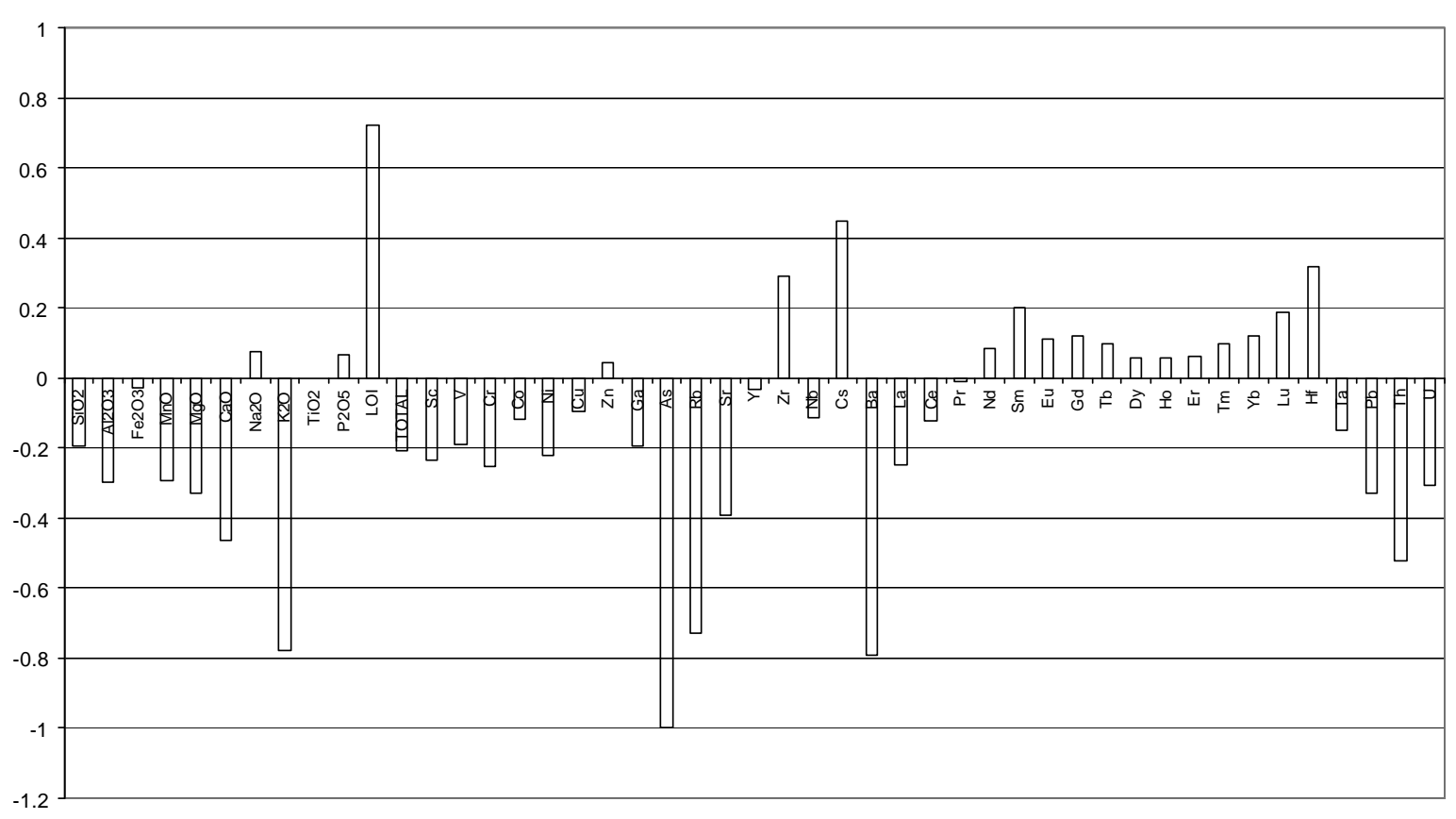

Figura 4.13 - Balanço de perdas e ganhos de componentes entre a média das amostras isótropas e a média das amostras miloníticas. Cálculos considerando TiO2 imóvel, e ganhos/perdas relativos à massa inicial de cada componente 


\subsection{Análise da geometria da zona de cisalhamento Ribeira}

A inflexão sigmoidal que fazem as estruturas ao norte do Lineamento Ribeira sugere fortemente uma geometria de zona de cisalhamento dúctil, como já observou Sadowski (1983). Uma forma de analisar a geometria das zonas de cisalhamento é através do desenho de isógonas (no caso, linhas que unem pontos com mesma direção da foliação das rochas) das estruturas sigmóides que se formam em torno delas (Ramsay \& Huber, 1983, p.37, fig. 3.5). Se a deformação for toda devida a um sistema de cisalhamento simples heterogêneo e, se as estruturas afetadas tiverem um comportamento passivo (isto é, sem contraste de competência), deve-se esperar isógonas aproximadamente paralelas à zona de cisalhamento.

A figura 4.1 mostra simplificadamente o padrão de isógonas obtido. As isógonas foram traçadas a partir do desenho de direções médias das estruturas, que forma a superfície axial na charneira das macrodobras mapeadas, e So//Sx nos seus flancos. Foi adotada como referência a direção da porção sul do Lineamento Ribeira $\left(\alpha^{\prime}=0\right)$.

Nota-se para as isógonas um paralelismo aproximado com o Lineamento Ribeira, mantido somente até a isógona de $25^{\circ}$ A primeira isógona a aparecer é a de $10^{\circ}$. Este é aproximadamente o menor ângulo que fazem as estruturas mapeadas com o Lineamento Ribeira.

A partir dos $30^{\circ}$, as isógonas são fortemente defletidas quando alcançam a zona de influência dos lineamentos Agudos Grandes e Figueira. Este comportamento se deve ao truncamento das estruturas, produzido provavelmente pela movimentação diferencial com relação ao Lineamento Ribeira. Este truncamento é de muito baixo ângulo, quando visto em planta, e percebido somente com muita atenção nos mapas geológico-estruturais, e em fotos aéreas. Porém é ressaltado pelo traçado das isógonas.

No Bloco Lajeado o padrão é totalmente diverso, provavelmente devido à alternância de pacotes com forte contraste de ductilidade, além da ação de várias zonas de cisalhamento menores, bem como por efeitos deformativos provocados pela intrusão do Granito Itaoca. No Bloco Andorinhas, o padrão de isógonas foge também ao previsto pelo modelo de zonas de cisalhamento simples.

$\mathrm{Na}$ porção leste do Bloco Ribeira, onde o traçado das isógonas é mais homogêneo, elaborou-se um gráfico de cisalhamento versus distância, visando estimar o deslocamento dúctil produzido pelo Lineamento Ribeira, conforme proposto por Ramsay \& Graham (1970).

Para o cálculo do valor de cisalhamento em cada ponto, considerou-se que as estruturas dispostas agora em forma de sigmóide, seriam pré-cisalhamento, e foram rotacionadas por este de modo passivo. Esta interpretação é apoiada pelo fato destas estruturas fazerem regionalmente ângulos muito altos com a direção de cisalhamento. $\mathrm{Na}$ área estudada, e um pouco a norte dela, as estruturas chegam a um ângulo de aproximadamente $60^{\circ} \mathrm{com}$ o Lineamento Ribeira. Dentro do modelo de zona de cisalhamento dúctil, produzida unicamente por cisalhamento simples 
heterogêneo, o ângulo máximo que pode fazer a xistosidade (i.e., o plano de máximo achatamento do elipsóide de deformação finita) com a zona de cisalhamento, seria de $45^{0}$. Assim, considerando o ângulo $\alpha$ máximo que as estruturas fazem com a zona de cisalhamento, como $\alpha=60^{\circ}$ o valor $\gamma$ de cisalhamento pode ser calculado pela relação (Ramsay, 1980):

$$
\begin{gathered}
\operatorname{cotg} \alpha^{\prime}=\operatorname{cotg} \alpha+\gamma \\
\gamma=\operatorname{cotg} \alpha^{\prime}-\operatorname{cotg} 60^{\circ}
\end{gathered}
$$

onde $\alpha^{\prime}$ é o ângulo que a linha passiva faz com a zona de cisalhamento num determinado ponto.

Os parâmetros da deformação em cada ponto podem ser obtidos a partir da matriz de deformação

$$
\left[\begin{array}{lll}
1 & \gamma & 0 \\
0 & 1 & 0 \\
0 & 0 & 1
\end{array}\right]
$$

Ou por equações algébricas dela derivadas, como se segue. Lembrando que todos esses parâmetros são apenas para a componente de cisalhamento simples calculada.

O ângulo $\theta^{\prime}$ que o eixo maior do elipsóide de deformação produzido faz com a direção de cisalhamento é dado por:

$$
\operatorname{tg} 2 . \theta^{\prime}=2 / \gamma
$$

As elongações quadráticas $\lambda_{1}$ e $\lambda_{3}$ respectivamente dos eixos maior e menor do elipsóide de deformação são dadas por:

$$
\begin{aligned}
& \lambda_{1}=1 / 2\left[2+\gamma^{2}+\left(\gamma^{2}+4\right)^{1 / 2}\right. \\
& \lambda_{3}=1 / 2\left[2+\gamma^{2}-\left(\gamma^{2}+4\right)^{1 / 2}\right.
\end{aligned}
$$

A partir destas relações, construiu-se a tabela 4.8, na qual se vêem os valores teóricos esperados de $\gamma, \theta^{\prime}, \lambda_{1}, \lambda_{3}$ e $R_{S}$, esperados para cada ângulo $\alpha^{\prime}$ da figura 4.1. Note-se que $R_{S}$ deve atingir valores muito altos próximo ao Lineamento Ribeira, da ordem de 1:30 (para $\alpha^{\prime}=10^{\circ}$ ). Estes valores de deformação muito altos podem explicar as feições miloníticas observadas em alguns pontos.

A figura 4.14 mostra a curva de cisalhamento versus distância construída para o perfil indicado na figura 4.1. A área sob esta curva (sua integral) indica o deslocamento (rejeito) produzido pela zona de cisalhamento (Ramsay \& Graham, 1970). No caso, o rejeito dúctil estimado para o bloco norte do Lineamento Ribeira foi de $18 \mathrm{~km}$. 


\begin{tabular}{|c|c|c|c|c|c|}
\hline$\alpha^{\prime}$ & $\gamma$ & $\theta^{\prime}$ & $\lambda_{1}$ & $\lambda_{3}$ & $\mathrm{R}_{\mathrm{s}}$ \\
\hline 60 & 0 & - & 1.00 & 1.00 & 1.00 \\
\hline 55 & 0.12 & 43.24 & 1.13 & 0.88 & 1.13 \\
\hline 50 & 0.26 & 41.27 & 1.30 & 0.77 & 1.30 \\
\hline 45 & 0.42 & 39.03 & 1.52 & 0.66 & 1.52 \\
\hline 40 & 0.61 & 36.46 & 1.83 & 0.55 & 1.83 \\
\hline 35 & 0.85 & 33.48 & 2.29 & 0.44 & 2.29 \\
\hline 30 & 1.15 & 30.00 & 3.00 & 0.33 & 3.00 \\
\hline 25 & 1.57 & 25.96 & 4.22 & 0.24 & 4.22 \\
\hline 20 & 2.17 & 21.33 & 6.56 & 0.15 & 6.56 \\
\hline 15 & 3.15 & 16.19 & 11.87 & 0.08 & 11.87 \\
\hline 10 & 5.09 & 10.72 & 27.91 & 0.04 & 27.91 \\
\hline 5 & 10.85 & 5.22 & 119.77 & 0.01 & 119.77 \\
\hline
\end{tabular}

Tabela 4.8 - Valores teóricos de cisalhamento associados ao Lineamento Ribeira, para $\alpha=60^{\circ}$.

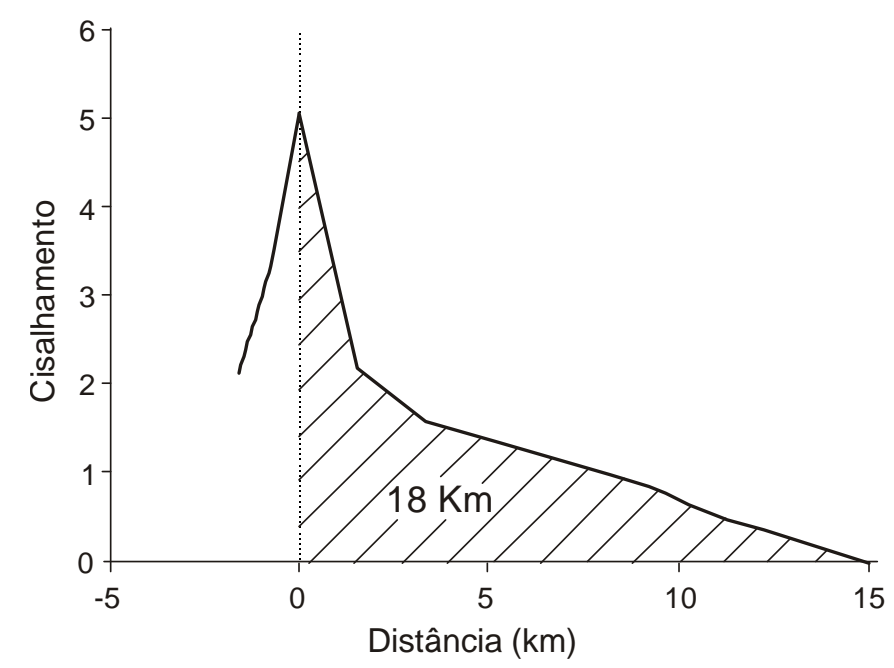

Figura 4.14 - Estimativa do rejeito dúctil associado ao bloco norte do Lineamento Ribeira, através do cálculo da área sob a curva de cisalhamento $(\gamma)$ versus distância.

A figura 4.15 mostra outra forma de estimativa do rejeito associado ao Lineamento Ribeira, por meio das correlações litoestratigráficas e da própria inflexão regional das estruturas. Os rejeitos foram tomados na direção mediana do lineamento. O rejeito total estimado desta forma foi de $50 \mathrm{~km}$, sendo $16 \mathrm{~km}$ de rejeito dúctil no bloco norte, possivelmente cerca de $14 \mathrm{~km}$ de rejeito rúptil dado pela interrupção da continuidade da Formação Iporanga e sua possível continuidade nos metarritmitos da Formação Votuverava no Paraná, e 20 km de rejeito dúctil no bloco sul. 


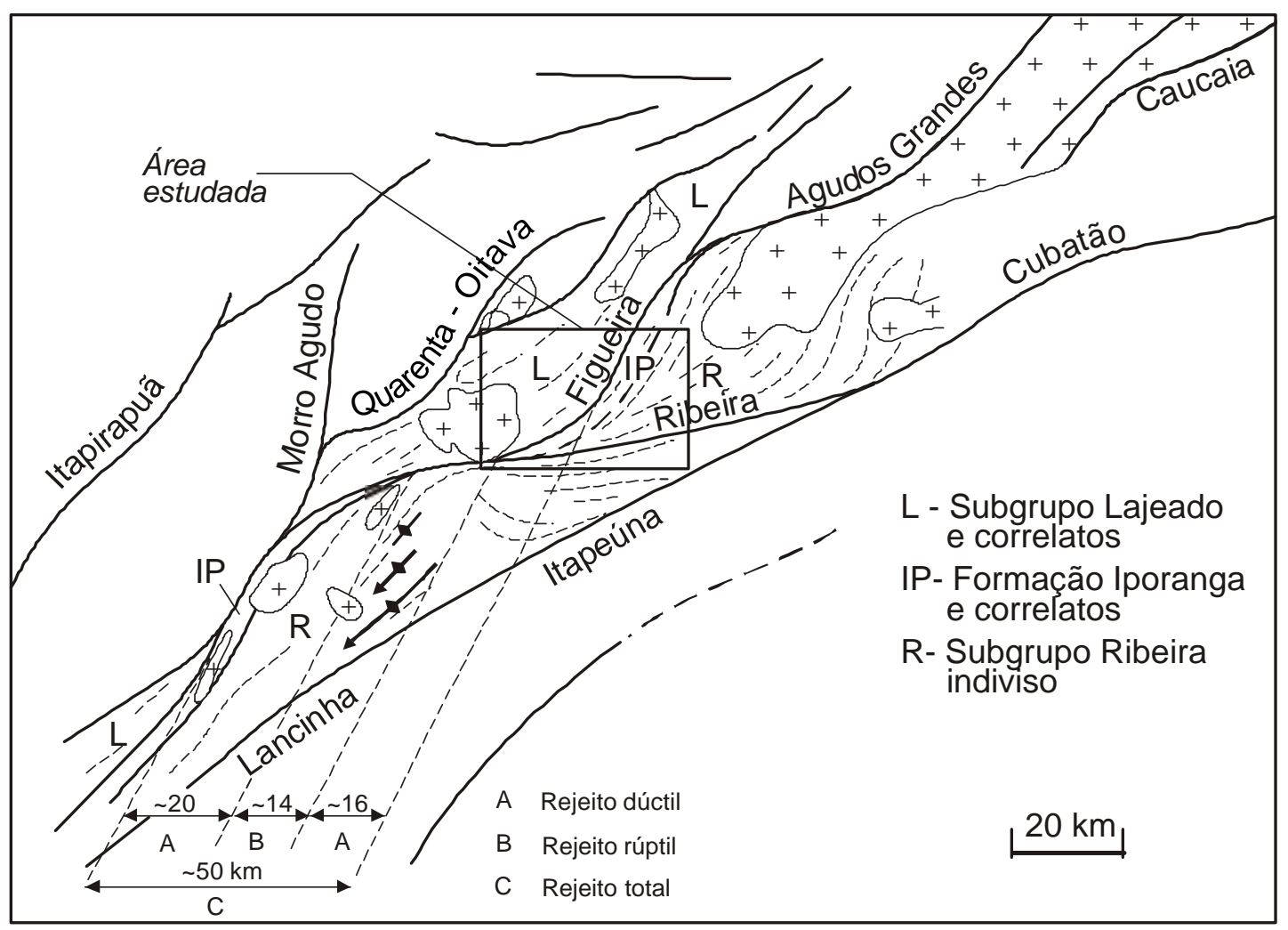

Figura 4.15 - Estimativas do rejeito ao longo do Lineamento Ribeira por correlações regionais.

Considerando-se a deformação como produzida não só por cisalhamento simples, mas também por achatamento uniaxial, tem-se a seguinte relação (Ramsay, 1980):

$$
\begin{aligned}
& \operatorname{cotg} \alpha^{\prime}=\operatorname{cotg} \alpha / F v+\gamma \\
& \gamma=\operatorname{cotg} \alpha^{\prime} \cdot F_{V}-\operatorname{cotg} 60^{\circ}
\end{aligned}
$$

Lembrando que o fator volumétrico aqui usado é

$$
F_{V}=V_{1} / V_{0}
$$

enquanto que a variação volumétrica $\Delta \mathrm{V}$ utilizada por Ramsay é

$$
\Delta \mathrm{V}=\left(\mathrm{V}_{1}-\mathrm{V}_{0}\right) / \mathrm{V}_{0}
$$

e portanto

$$
\mathrm{F}_{\mathrm{V}}=\Delta \mathrm{V}+1
$$

Considerando um fator volumétrico médio calculado no item anterior como $F_{v} \cong 0,84$, e considerando esse valor como constante através da zona de cisalhamento, obtemos os valores recalculados de $\gamma$ na Tabela 4.9 bem como o parâmetro $\mathrm{K}$ de Flinn e a razão de strain Rs. 
Lembrando ainda que estes parâmetros referem-se só às componentes de cisalhamento simples e achatamento uniaxial calculadas. Estes parâmetros foram obtidos a partir da matriz de deformação:

$$
\left[\begin{array}{ccc}
1 & \gamma & 0 \\
0 & F_{v} & 0 \\
0 & 0 & 1
\end{array}\right]
$$

Considerando que a perda de volume associada à milonitização só deve ocorrer com valores significativos próximo ao Lineamento Ribeira, estimou-se que o cálculo do rejeito da Figura 4.14 deve reduzir-se em cerca de 10\%, tornando-se mais próximo ao calculado por correlações regionais (Figura 4.15).

\begin{tabular}{|r|r|r|r|r|}
\hline \multicolumn{1}{|c|}{$\alpha^{\prime}$} & $\gamma$ & \multicolumn{1}{c|}{$\theta^{\prime}$} & \multicolumn{1}{c|}{$\mathrm{K}$} & \multicolumn{1}{c|}{$\mathrm{Rs}$} \\
\hline 60 & & & 0 & 1.19 \\
\hline 55 & 0.011 & 1.767 & 0.001 & 1.19 \\
\hline 50 & 0.127 & 17.3 & 0.112 & 1.25 \\
\hline 45 & 0.263 & 25.3 & 0.287 & 1.40 \\
\hline 40 & 0.424 & 28.2 & 0.433 & 1.63 \\
\hline 35 & 0.622 & 28.4 & 0.543 & 1.99 \\
\hline 30 & 0.878 & 27.1 & 0.625 & 2.56 \\
\hline 25 & 1.22 & 24.4 & 0.688 & 3.53 \\
\hline 20 & 1.73 & 20.7 & 0.736 & 5.41 \\
\hline 15 & 2.56 & 16.1 & 0.773 & 9.71 \\
\hline 10 & 4.19 & 10.8 & 0.802 & 22.8 \\
\hline 5 & 9.02 & 5.25 & 0.824 & 99.0 \\
\hline
\end{tabular}

Tabela 4.9 - Valores de $\gamma, \theta^{\prime}, K$ (Flinn) e Rs (razão de strain) calculados para o Lineamento Ribeira, considerando $\alpha=60$ e um fator volumétrico constante $F v=0,84$.

Fiori (1985, 1997), analisando as falhas do Morro Agudo e Lancinha, com abordagem semelhante à aqui adotada, obteve rejeitos dúcteis totais significativamente diferentes, da ordem de 87 a 122 km para a primeira, e de 100 a $142 \mathrm{~km}$ para a segunda. Para a Falha da Lancinha seria mesmo esperável um rejeito maior, já que esta é considerada pela maioria dos autores como uma das mais importantes do sistema, representando um limite crustal mais significativo. Para a Falha do Morro Agudo, a qual se une com o Lineamento Ribeira, tal diferença ainda permanece por ser melhor explicada. Observa-se que os eixos de dobras e traços de foliação da área analisada por Fiori (op. cit.) apresentam um padrão quase paralelo com os traços das zonas de cisalhamento, sobre uma faixa mais larga, quando comparados com a área aqui analisada, implicando no cálculo de valores de $\gamma$ mais altos, e portanto de rejeitos maiores. Este maior paralelismo por sua vez poderia ser tentativamente explicado ou pela maior proximidade com a Falha da Lancinha, ou pela ocorrência de componentes de achatamento perpendiculares à faixa. 


\subsection{Retroanálise da deformação}

Um dos objetivos da realização de determinações de strain finito nas rochas é, entre outros, a tentativa de recuperar a configuração geométrica dos corpos geológicos antes da deformação.

Uma das dificuldades teóricas dessa tentativa é que usualmente as medidas de deformação finita em rochas (Fry, $\mathrm{R}_{\mathrm{F}} / \phi$, etc.) correspondem apenas à componente simétrica de strain (distorção) da deformação finita. Não incluem informações sobre a componente de rotação de corpo rígido eventualmente envolvida.

Assim, uma matriz de deformação $\mathbf{F}$ pode ser decomposta numa componente simétrica $\mathbf{e}$ numa componente de rotação (ver capítulo 2):

$$
\mathbf{F}=\mathbf{V} \cdot \mathbf{R}
$$

onde $\mathbf{V}$ é o tensor de extensão esquerdo e $\mathbf{R}$ a matriz de rotação.

O elipsóide de deformação finita obtido de medidas nas rochas corresponde às direções e valores principais de $\mathbf{V}$. Porém, para determinar-se $\mathbf{R}$, é necessário saber-se qual era a orientação de linhas correspondentes aos eixos principais de deformação no estado inicial.

Numa situação bidimensional, uma seção geológica por exemplo, é possível restaurar-se a configuração original, admitindo-se o acamamento original como horizontal.

Já numa situação tridimensional não basta por exemplo saber-se que o acamamento era horizontal; ter-se-ia que conhecer também a orientação original de uma linha dentro do acamamento, por exemplo, uma direção de corrente.

Configurações pressupostas como originadas por deformação plana, como cisalhamento simples ou puro, também podem ser reduzidas a uma situação bidimensional (não há deformação na direção $Y$ do elipsóide, e portanto os cálculos podem restringir-se à seção $X Z$ ).

No modelo clássico de zonas de cisalhamento, a componente de rotação pode ser calculada a partir da deflexão da superfície S gerada ou da deflexão de superfícies pré-existentes, para as quais se conhece a orientação fora da zona de cisalhamento (como aqui realizado no item 4.3).

No caso do Lineamento Ribeira, supondo a ocorrência de deformações sobrepostas, sendo F a matriz de deformação total, CS a matriz associada ao cisalhamento simples, F1 a matriz associada a uma deformação anterior, temos:

$$
\mathbf{F}=\mathbf{C S} . \mathbf{F 1}
$$


Para cada ponto do campo de deformação em torno do Ribeira, a matriz CS pode ser calculada a partir dos parâmetros determinados item 4.3.

Podemos querer saber qual era a natureza da deformação existente anterior ao cisalhamento simples, ou seja, determinar F1. Assim, teríamos:

$$
\mathbf{F 1}=\mathrm{CS}^{-1} \cdot \mathbf{F}
$$

Para a deformação final, total, $\mathbf{F}$, temos apenas a componente simétrica da deformação, ou seja, as magnitudes e as orientações do elipsóide de deformação finita associadas ao tensor $\mathbf{V}$.

$$
\mathbf{F 1}=\mathrm{CS}^{-1} \cdot \mathbf{V} \cdot \mathbf{R}
$$

Onde CS (cisalhamento simples transcorrente) e $\mathbf{V}$ (elipsóide de deformação finita) são conhecidos. Porém, R não é conhecida, e portanto F1 não pode ser determinada só com estes parâmetros.

O que pode ser feito por ora é verificar se os padrões de strain finito obtidos (tensor V) são ou não compatíveis com alguns modelos de deformação, por exemplo transpressão ou empurrão seguido de transcorrência.

\subsection{Discussão}

Os resultados obtidos, aliados a dados de campo, regionais e de detalhe, mostraram consistência, seja com o padrão de xistosidade e estruturas menores observado, seja na aplicação de diferentes métodos em uma mesma amostra, na comparação com os valores de encurtamento deduzidos do dobramento de unidades estratigráficas e com os valores de cisalhamento obtidos pela análise das inflexões regionais produzidas pelo Lineamento Ribeira.

Os métodos aplicados para a determinação de strain, adaptados dos existentes na literatura, foram escolhidos visando uma abordagem preliminar do problema, onde seria mais importante um maior número de estimativas semi-quantitativas distribuídas regionalmente, do que um número menor de determinações precisas e localizadas. Os métodos gráficos adotados, embora mais trabalhosos e aparentemente menos precisos, permitiram por outro lado o controle visual de diversos parâmetros, como o ajuste de compatibilidade entre as seções de medida, evitando erros grosseiros. Algumas ressalvas no entanto devem ser feitas. As técnicas utilizadas permitem em geral apenas a análise de rochas com granulação relativamente grossa (metassiltitos, metarenitos e metaconglomerados). Deste modo, as rochas de granulação mais fina, em geral mais incompetentes, e potencialmente mais deformadas, são subamostradas. Por outro lado, para as rochas pouco deformadas, existe uma indeterminação das direções principais, já que o elipsóide aproxima-se de uma esfera. 
As orientações obtidas dos eixos principais de deformação finita sugerem a predominância de direções de estiramento máximo (X) subhorizontais NE-SW. Exceção é a região dos Lineamento Figueira e Agudos Grandes, onde a direção de máximo estiramento $(\mathbf{X})$ apresenta fortes mergulhos, para NW ou N/S, confirmando a movimentação inversa ou oblíqua dessas estruturas. Os eixos $\mathbf{Z}$ obtidos são em geral coerentes com um plano de máximo achatamento com direção NE e mergulho forte para NW, concordante com a orientação média da xistosidade e clivagem ardosiana na área.

A porção central do Lajeado aponta deformação finita em geral muito baixa. Foram obtidos valores de $X / Z$ entre 1,31 e 1,91. Esta aumenta em direção às zonas de cisalhamento (2,30 e $2,79)$, e dentro do Bloco Ribeira $(5,74$ e 8,93$)$. Isto concorda com o estilo deformacional observado nessas unidades.

O cálculo de extensões ao longo da direção horizontal NW, a partir dos dados de strain obtidos, é compatível com os resultados de encurtamento por dobramento das unidades estratigráficas observadas no perfil com essa direção (médias de cerca de 0,8 para o bloco Lajeado, e 0,3 para o bloco Ribeira).

A maior parte dos elipsóides obtidos aproxima-se do tipo com $k=1$. Três deles são fortemente prolatos $(k>>1)$ e dois são fortemente oblatos $(k<<1)$.

As análises de variação volumétrica de metabasitos afetados pelo Lineamento Ribeira sugerem uma fator $F_{v}$ médio em torno de 0,79 e 0,87. Embora apreciáveis, esses valores são substancialmente menores que os obtidos na literatura, para milonitos derivados de granitóides (O’Hara \& Blackburn, 1989; Glazner \& Bartley, 1991; Mohanty \& Ramsay, 1994).

Análise de geometria da Zona de Cisalhamento do Lineamento Ribeira mostra um deslocamento destral dúctil do bloco norte de cerca de $18 \mathrm{~km}$. O deslocamento total inferido é de cerca de $50 \mathrm{~km}$, por correlações regionais. A inclusão do fator volumétrico melhora o ajuste entre os cálculos do rejeito por integração do cisalhamento e por correlações regionais.

Os elipsóides oblatos obtidos no bloco Ribeira (amostras IP538 e F198) podem a princípio ser explicados tanto por perda de volume (modelo de Ramsay \& Graham), como por transpressão (modelo de Sanderson \& Marchini), como por empurrões seguidos de transcorrência (Merle \& Gapais, 1997). O ângulo relativamento alto entre a foliação observada e a zona de cisalhamento do Ribeira no ponto IP538 é uma evidência mais favorável ao terceiro modelo. O ponto F198 por outro lado situa-se praticamente na junção entre os lineamentos Figueira e Ribeira, também representando um contexto favorável ao terceiro modelo.

De um modo geral, a ocorrência de foliações em ângulos altos com o Lineamento Ribeira (até $60^{\circ}$ ) favorece mais um modelo de empurrões com direção NNE seguidos de transcorrência ENE.

A ocorrência de vários elipsóides prolatos merece alguma atenção adicional. A princípio, poderiam ser vinculados a uma tectônica transtracional. Porém a ocorrência de foliações predominatemente empinadas não é favorável a este modelo. 
No âmbito do Bloco Lajeado, principalmente nos pontos com baixa deformação e acamamento não muito inclinado, os elipsóides prolatos podem também ser explicados pelo efeito de compactação vertical devido ao soterramento sedimentar, seguida de transcorrência. A seguinte matriz de deformação:

$$
\left[\begin{array}{lll}
1 & \gamma & 0 \\
0 & 1 & 0 \\
0 & 0 & s
\end{array}\right]
$$

onde $\gamma$ é o cisalhamento associado a transcorrência EW e S é o achatamento vertical, produz elipsóides prolatos $(\mathrm{K}>1)$ para diversa faixas de valores desses parâmetros, principalmente quando a deformação tectônica for baixa. Produz foliações empinadas e lineações horizontais, com direções em ângulo com o azimute EW, conforme observado na porção central do Bloco Lajeado.

Os pontos IP060, P26 e IP939 mostram eixos X no rumo do mergulho (IP060) ou oblíqüos (P26 e IP039), estando na área de influência dos lineamentos Figueira e Agudos Grandes. Embora o primeiro seja totalmente coerente com um modelo de empurrão, os dois últimos mostram no entanto alguns aspectos contraditórios. Estes são prolatos, e a obliqüidade de seus eixos $\mathbf{X}$ daria uma componente sinistral, caso o movimento da capa seja de empurrão.

Um modelo possível para esses pontos (P26 e IP039), seria o de movimentos extensionais na Figueira e Agudos Grandes, seguidos de transcorrência sinistral, o que explicaria os elipsóides prolatos e o sentido sinistral.

Porém, como já discutido no item 2.2.8, em sistemas de empurrão seguido de transcorrência, a obliqüidade dos eixos $\mathbf{X}$ (e portanto de lineações de estiramento pressupostamente a eles paralelas), pode produzir efeitos aparente da capa com movimento direcional oposto ao ocorrido.

Em resumo, cremos que os padrões de distribuição da deformação finita observados atestam a importância de uma tectônica de blocos de diferentes ductilidades, fortemente impregnada pelo evento de tectônica transcorrente de caráter regional. Em termos de um strain partitioning de caráter aparentemente diacrônico, pode-se imaginar uma componente de cisalhamento simples de baixo ângulo de NW para SE, uma componente de encurtamento horizontal NW-SE, e uma componente de cisalhamento simples destral, com direção ENE-WSW. 


\section{ASPECTOS CONCLUSIVOS}

\subsection{Ensaio sobre a interpretação mecânica da rede de zonas de cisalhamento}

As evidências existentes demonstram que o sistema de zonas de cisalhamento transcorrentes que afetou a região possui grande importância, não só na compartimentação tectônica, como também no padrão da distribuição da deformação e das estruturas dos blocos intervenientes. As amplas inflexões sigmoidais das estruturas regionais, o incremento da deformação em direção às zonas de cisalhamento, e a predominância da posição subhorizontal de máximo estiramento atestam esta importância.

Analisando-se o mapa estrutural da Folha Itararé observa-se uma padrão complexo de lentes de cisalhamento nas mais diversas escalas (anexos D e E).

Existem a grosso modo duas orientações tectônicas definidas, uma mais antiga com direção NE-SW e uma mais nova com direção ENE-WSW. Secundariamente, observa-se alguns lineamentos maiores com direção NNE.

A direção NE-SW corresponde ao traço axial de grandes dobramentos (e.g., as estruturas do anticlinório da Serra do Cadeado e da região do Subgrupo Lajeado), associados a foliação plano-axial empinada (xistosidade ou clivagem de crenulação, conforme o caso). Em seqüências com predomínio de metapelitos, com estratos sedimentares pouco espessos e com baixo contraste de competência, esta estrutura pode corresponder a uma foliação de transposição intensa. Falhas inversas também podem estar associadas a esta direção (e.g., Lineamento da Figueira).

A direção ENE - WSW está associada a faixas em geral mais estreitas de rochas fortemente cisalhadas, associadas por vezes a brechas cataclásticas, rochas miloníticas quando afetam litologias adequados (granitos, gnaisses, anfibolitos, quartzitos) e mais comumente a filonitos e xistos com estrutura fortemente lenticularizada e estruturas primárias destruidas, quando afetam metapelitos. Exemplo típico é o Lineamento Ribeira.

As estruturas NNE são mais restritas, defletem as anteriores, com rotação aparente sinistral. Exemplo típico é o Lineamento do Morro Agudo.

Portanto, as relações entre estas estruturas sugerem uma seqüênciação temporal, sendo o Lineamento da Figueira (NE empurrão oblíquo) mais antigo, deflexionado pelo Lineamento Ribeira (ENE destral), o qual por sua vez é deflexionado pelo Lineamento do Morro Agudo (NNE sinistral). O Lineamento Lancinha intersecta todas estas estruturas.

De um modo geral, as estruturas ENE são mais tardias, defletindo e rotacionando as NE, com sentido destral.

Um limite tectônico importante é o Lineamento Lancinha - Cubatão, o qual limita blocos crustais com características distintas. Um aspecto interessante é que as zonas de cisalhamento 
no bloco ao sul deste lineamento apresentam indicadores cinemáticos predominantemente sinistrais, enquanto que no bloco norte são predominantemente destrais.

Em tese, é possível elaborar um modelo deformacional que procure explicar a maior parte das deformações observadas em termos de um sistema único de cisalhamento transcorrente ou transpressivo. As variações de orientação e intensidade das foliações tectônicas seriam devidas à variação de posição e forma do elipsóide de deformação, num processo de deformação heterogênea. A lenticularização tectônica regional, com blocos transpressivos e transtensivos também induziria a estilos estruturais distintos em várias áreas.

No entanto, existem evidências de que o sistema transcorrente afeta estruturas tectônicas anteriormente desenvolvidas. O desenvolvimento da xistosidade regional não se coaduna totalmente com o modelo de zonas de cisalhamento simples, já que este por vezes faz ângulos maiores que $45^{\circ} \mathrm{com}$ a mesma. Isto seria possível apenas num regime transtrativo, ou seja, com extensão perpendicular ao cinturão, o que não parece razoável, já que as foliações deveriam ser predominatemente horizontais. Granitos pós- ou tardi-tectônicos são afetados pelas zonas de cisalhamento transcorrentes, como o Itaoca, milonitizado pelo Lineamento Ribeira em seu extremo sul. A intrusão deste granito por sua vez deforma pelo menos uma xistosidade pré-existente, e provoca o crescimento de uma associação mineralógica termal sobre esta xistosidade e paragêneses minerais pré-existentes. Estas evidências sugerem ou que haja um lapso de tempo entre o desenvolvimento inicial da xistosidade $\left(S_{1}\right)$ e o cisalhamento transcorrente, ou que esses eventos sejam recorrentes no tempo.

Considerando a trama estrutural de grandes lentes de cisalhamento do bloco a norte do Lineamento Lancinha, e no tocante aos dois conjuntos básicos de estruturas, com orientações NE e ENE, pode-se levantar preliminarmente duas hipóteses:

a) foram geradas em processos tectônicos distintos;

b) são o resultado de um processo tectônico único.

Na primeira hipótese (a) não haveria relação tectônica entre as duas direções estruturais. Deve-se então pressupor que sua relação espacial é fortuita ou que a segunda deformação rotacionou a mais antiga até sua posição atual.

A hipótese mais simples é de que as duas orientações estruturais estejam associadas a um único evento tectônico (b), que seria a convergência oblíqua de duas placas.

A trama NE estaria relacionada à convergência das placas e fechamento oceânico (figura 5.1). Com a colisão oblíqua passam a se desenvolver dois sistemas conjugados de cisalhamento, um principal ENE destral (Ribeira) e um secundário NNE sinistral (Morro Agudo). Os movimentos finais (tardios) seriam controlados pelo cisalhamento paralelo à borda de placa, constituida pelo Lineamento Lancinha. 


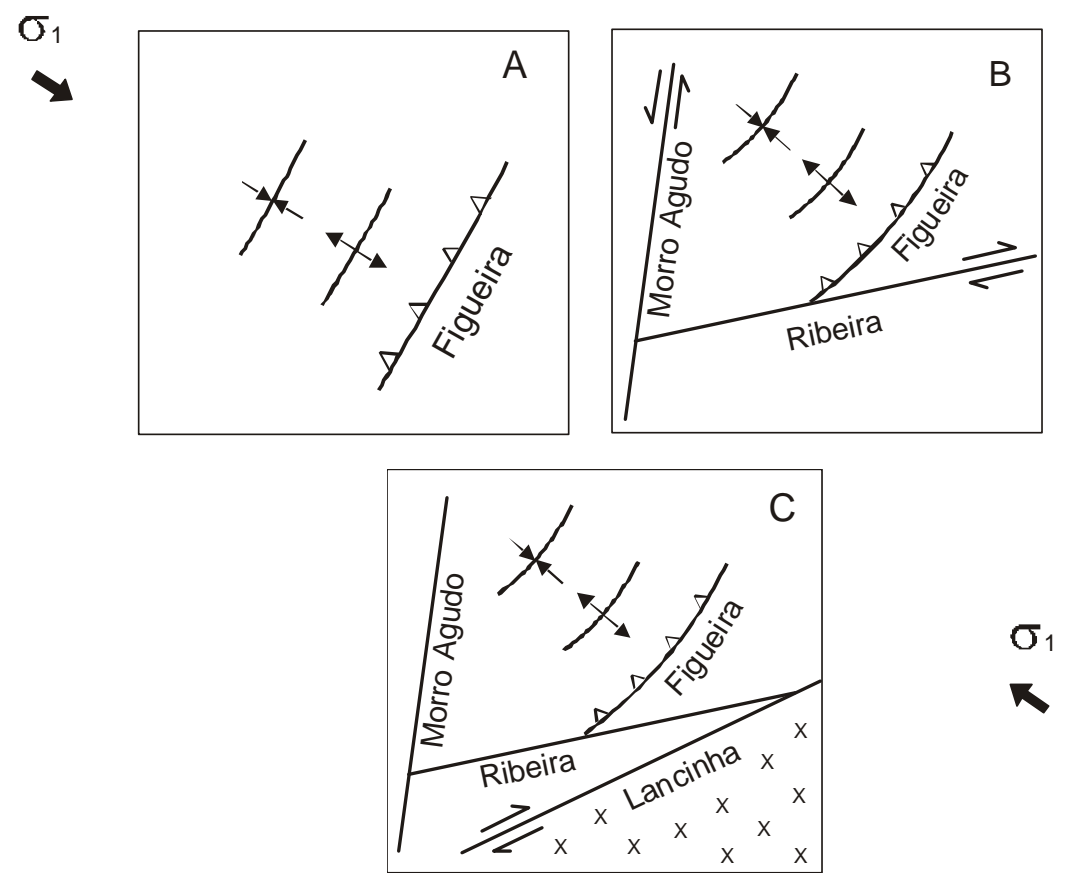

Figura 5.1 - Modelo de evolução mecânica vinculado a colisão oblíqua.

Este modelo prevê um episódio inicial compressivo, caracterizado por empurrões seguidos por dobramento (figura $5.1 \mathrm{~A}$ ), passando a um regime transcorrente (figura $5.1 \mathrm{~B}$ ), com movimentos mais tardios condicionados pela borda de placa (figura $5.1 \mathrm{C}$ ).

Este modelo tem implicações relacionadas com: (i) a orientação das tensões principais; e (ii) a orientação da lineação associada.

Conforme os modelos tectônicos clássicos (e.g., Anderson 1951) as orientações das tensões principais são diferentes para os sistemas de empurrão e transcorrentes. No primeiro caso $\sigma_{3}$ é vertical, enquanto que no segundo $\sigma_{2}$ é a tensão principal vertical, sendo $\sigma_{\text {? horizontal }}$ em ambos os casos.

Considerando a evolução do sistema de tensões durante a colisão de placas, é provável que um episódio inicial de empurrão ocorra. A tensão mínima $\sigma_{3}$ deve ser vertical. Com o desenrolar do processo de colisão os empurrões têm seu movimento bloqueado, e a compressão passa a ser acomodada por dobramento. A tensão vertical é incrementada e é possível que em algum momento da história deformacional ela cresça ao ponto de se converter em $\sigma_{2}$. Quando isto ocorre os empurrões dão lugar a transcorrências.

A orientação das lineações de estiramento irá mudar quando o regime tectônico mudar de empurrão para transcorrente.

O sistema inicial idealmente origina falhas com mergulho de $0^{\circ}$ a $30^{\circ}$ para NW ou SE, com lineações com orientação NW - SE.

É importante considerar o que acontece quando o sistema de empurrões dá lugar ao dobramento, um processo mais provável de ocorrer em unidades bem estratificadas do que naquelas de estrutura mais isotrópica. Deverá ocorrer a formação de uma clivagem plano - axial 
empinada, e é provável que esta contenha uma lineação. Se o $\sigma_{3}$ ainda for vertical, espera-se que a lineação seja vertical. Se a tensão vertical tiver mudado de $\sigma_{3}$ para $\sigma_{2}$ durante o dobramento então a lineação nos planos de clivagem deverá ser horizontal.

A orientação predominante das lineações de estiramento no Cinturão Ribeira e na área estudada é sub-horizontal ENE-WSW. Localmente, como na área afetada pelo Lineamento Figueira, ocorrem lineações com alto ângulo de mergulho, em posição down dip ou quase, que poderiam corresponder ao episódio inicial. De qualquer modo, é necessário argumentar que as lineações iniciais nos planos de empurrão (mais alguma na xistosidade associada ao dobramento, se esta tiver sido gerada em posição subvertical), foram sobrepostas e/ou reorientadas pela tectônica transcorrente.

\subsubsection{A questão do ângulo dos diedros compressivos}

Além do sistema transcorrente ENE principal de natureza destral, existe outro com orientação NNE sinistral (e.g., Lineamento do Morro Agudo). Suas relações de intersecção sugerem contemporaneidade e atuação como pares conjugados. Porém o ângulo entre os dois sistemas do diedro compressional é da ordem de 100 - 120 graus (figura 5.2), o que não é compatível com os critérios clássicos de ruptura por cisalhamento.

Duas hipóteses de explicação são aventadas:

1) que estas representem ruptura por cisalhamento clássica e que as condições de borda (i.é., a orientação da margem de placa) controlem a orientação dos planos de cisalhamento (os quais normalmente ocorreriam a um ângulo de cerca de $30^{\circ} \mathrm{com} \sigma$ );

2) que estas representem um par conjugado de estruturas $\mathbf{C}$ em condições de plasticidade, cuja orientação inicial é de $45^{\circ} \mathrm{com} \sigma_{\text {? }}$ formando um ângulo diedral inicial entre elas de $90^{\circ}$. Com o prosseguimento da deformação dúctil, o ângulo do diedro compressivo tenderia a aumentar.

A interpretação das estruturas NNE sinistrais como conjugadas das direções ENE destrais predominantes traz implicações interessantes. Como a deformação na região ocorreu num regime dúctil a semi-dúctil, após a geração de um par conjugado e com o prosseguimento da compressão, dois fenômenos podem ocorrer:

- o ângulo no diedro compressivo aumenta;

- sendo o sistema destral predominante, as estruturas NNE sinistrais geradas tendem a rotacionar no sentido horário, e a criar espaços abertos.

Tomando-se a bissetriz do ângulo obtuso entre as direções médias do Lineamento Ribeira (N079E) e Morro Agudo (N004E), obtém-se uma direção estimada de $\sigma_{?}$ como N048W. Por outro lado, tomando-se a direção perpendicular à z.c. inversa da Figueira, estima-se um azimute de N066W para $\sigma_{3}$ que faria então um ângulo de $35^{\circ} \mathrm{com}$ o Lineamento Ribeira, coerente com o critério de Mohr - Coulomb, e de $70^{\circ} \mathrm{com}$ o Morro Agudo, que estaria rotacionado no sentido horário (figura 5.2). 


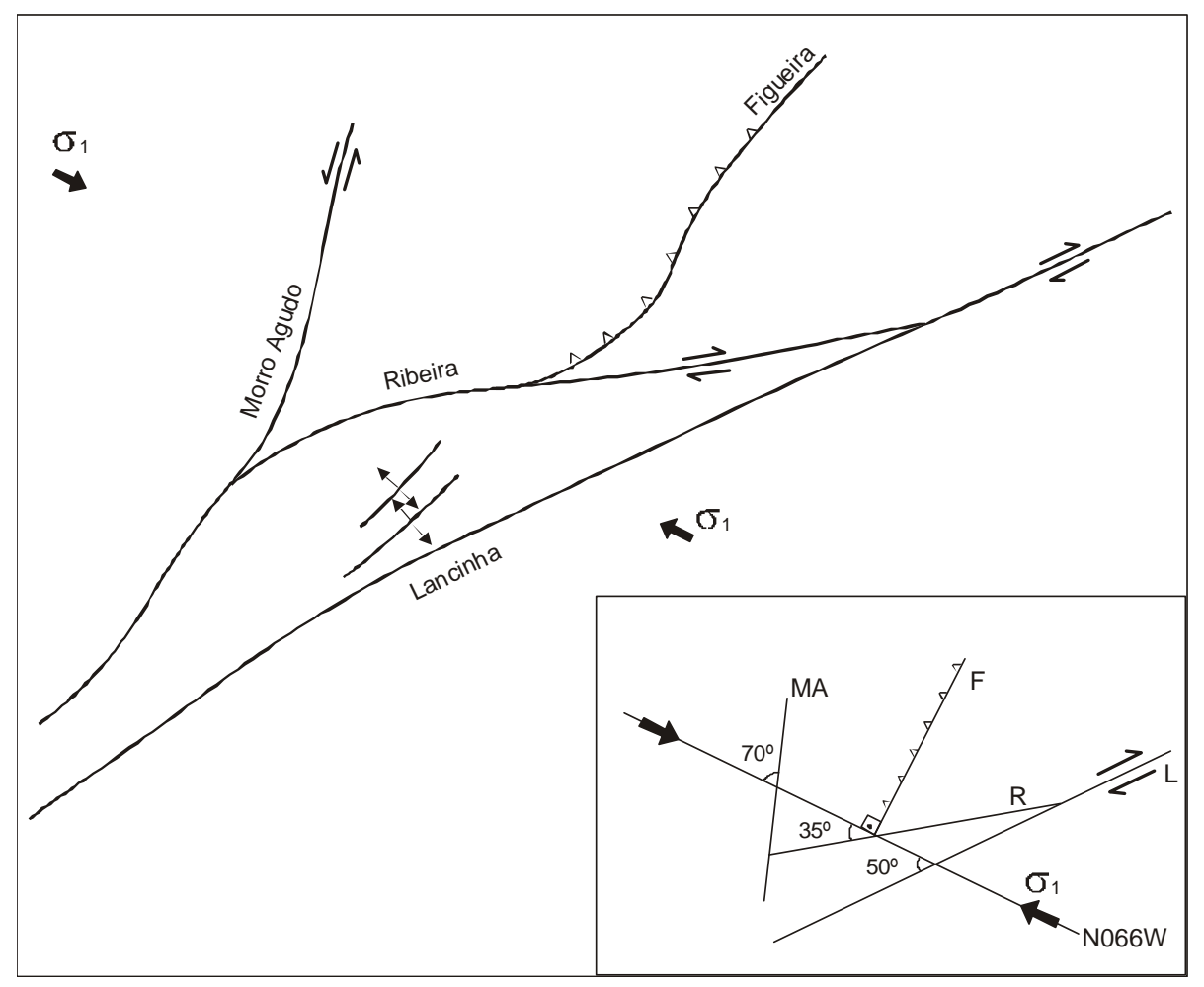

Figura 5.2 - Modelo de relações angulares entre os principais sistemas de cisalhamento e a direção de $\sigma_{\text {? }}$ interpretada.

\subsection{Implicações para a evolução do Cinturão Ribeira.}

O Cinturão Ribeira no Sudeste Brasileiro é consagrado como uma faixa móvel situada entre os crátons do São Francisco, Paraná, Rio de La Plata e Congo, no Gondwana Ocidental. É tipicamente caracterizado por uma rede entrelaçada de zonas de cisalhamentos transcorrentes predominantemente destrais.

Neste sentido pode ser visto como uma macro banda de deformação, bordejada por importantes zonas de cisalhamento direcionais e com uma padrão interno de lentes de cisalhamento sigmoidais, observável nas mais diferentes escalas.

Em que pesem algumas dificuldades sobre a datação dos eventos iniciais de sedimentação e vulcanismo, bem como ainda sobre a eventual existência de faixas vestigiais de idade mesoproterozóica (Serra de Itaberaba, Perau), algumas considerações podem ser traçadas sobre sua evolução tectônica.

A evolução de um arco de ilhas durante o Neoproterozóico pode ser aventada para algumas das seqüências vulcanossedimentares dos grupos São Roque, Itaiacoca e Ribeira. Frente aos dados atuais, não parece mais sustentável a hipótese de evolução como uma margem passiva para algumas dessas seqüências, como proposto por exemplo por Petri \& Suguio (1969) e Campanha \& Sadowski (1999). Associações mais coerentes com margens passivas estariam 
presentes nas bordas do Cráton do São Francisco (São João Del Rey, Andrelândia), e talvez às margens do Cráton Luís Alves (Formação Capiru mais Setuva). Terrenos / blocos de idades paleoproterozóica (Curitiba, Amparo, embasamento do Embu, Juiz de Fora) encontram-se imbricados com os terrenos neoproterozóicos, assim como os terrenos Embu e Paraíba do Sul. Desse modo a evolução neoproterozóica do cinturão pode ser entendida como a colagem de uma série de terrenos tectônicos, incluindo arcos de ilha, margens passivas e fragmentos de embasamento paleoproterozóico e mesmo arqueano. Extensivo magmatismo granitóide do tipo andino (Cunhaporanga, Três Córregos, Agudos Grandes / Piedade, Socorro, Serra dos Órgãos), como tal devendo estar associado a margem ativa com subducção, afeta essa unidades e acha-se associado às primeiras etapas seguramente reconhecidas da evolução do sistema transcorrente. O magmatismo granitóide relacionado a arco estaria associado a zonas de subducção situadas provavelmente mais a $\mathrm{E}$ ou SE

As características gerais até agora descritas para o sistema de zonas de cisalhamento da região sudeste permitem afirmar que no período principal de sua evolução, algo aproximadamente entre 600 e $500 \mathrm{Ma}$, este comportou-se como importante limite transformante. Afetava na região essencialmente crosta continental, como bem balizada pelas várias bacias tardias associadas ao sistema, cujos membros rudáceos incluem fragmentos das rochas imediatamente circundantes. Acha-se também associado a magmatismo granitóide.

A história evolutiva dessas zonas de cisalhamento é parcialmente conhecida. Sem dúvida estiveram ativas no período entre 0,6 e 0,5 Ga. A idade por volta de 0,6 Ga pode ser inferida através dos dados geocronológicos existentes para os milonitos da região de Três Rios (Delhal, Ledent e Cordani, 1969, Campanha, 1980, 1981), bem como para os milonitos da zona de cisalhamento de Boquira, ainda em condições profundas. Dehler (2002) conclui que o intervalo de 0,59 a 0,57 Ga é o mais provável para a anatexia regional no Médio Paraíba, que estaria associada ao regime transpressivo. Ebert et al. (1996), analisando as relações entre estruturas tectônicas e magmáticas, com datações U/Pb no Complexo Granítico Socorro, consideram que a atividade ígnea abrangeu um período de $55 \mathrm{Ma}$, começando associada a empurrões para NW a $0,65 \mathrm{Ga}$, e continuando em movimentos direcionais destrais a partir de 0,595 Ga. O limite mais jovem de $0,5 \mathrm{Ga}$ pode ser definido pela datação de dique de pegmatito que corta os milonitos da zona de cisalhamento de Três Rios (Campanha, 1980, 1981), bem como pela idade das varias bacias molassóides da região, as quais relacionam-se com as últimas etapas da evolução do sistema de zonas de cisalhamento transcorrente, provavelmente num regime de bacias de afastamento (pull - apart). Os dados radiométricos mostram que a sedimentação dessas bacias tardias ocorreu entre 606 - $530 \mathrm{Ma}$, e a ocorrência de Cloudina riemkeae indica o período 565 $543 \mathrm{Ma}$ (Teixeira, 2000). Pelo menos em parte as zonas de cisalhamento neste momento já atuavam num nível crustal mais superficial, dado o caráter sintectônico da sedimentação dessas bacias, o contato com o embasamento através de falhas rúpteis e a presença de seixos de milonitos nas bacias. 
As informações existentes de anisotropia sísmica (James \& Assumpção, 1996, Assumpção et al., 2001) mostram que a estruturação ENE vertical com lineação subhorizontal alcança o manto superior sob a Faixa Ribeira. Desse modo é necessário considerar que a região era um limite de placas no período 600 - $500 \mathrm{Ma}$, e como tal um limite transformante, envolvendo tanto crosta continental de um lado, como oceanos em fechamento (Campos Neto, 1999, 2000; Teixeira, 2000).

Uma evolução de abertura e fechamento de crosta oceânica especificamente na região seria provavelmente mais antiga que $600 \mathrm{Ma}$. No entanto, isto não significa que os ambientes de sedimentação dessas bacias eram exclusivamente continentais. Como mostra Teixeira (2000) a ocorrência do microfóssil Cloudina riemkeae indica que havia pelo menos conexão com mares mais extensos, o que por outro lado não implica na ocorrência de assoalho oceânico especificamente na região e nesse período.

Assim, a paleofisiografia imaginada para o período de evolução do sistema transcorrente ( 600 - $500 \mathrm{Ma})$ seria de uma série de cordilheiras e fossas, essencialmente longilíneas e paralelas às grandes z.c., e condicionadas pelo caráter transpressivo ou transtrativo dos diferentes segmentos do sistema. Haveria conexão com ambientes marinhos extensos, que poderia esta a sul (Adamastor) ou a oeste (Brazilides).

A evolução neoproterozóica e eopaleozóica da região estaria assim associada a um regime de convergência e colisão oblíquas de placas. Os paradigmas para o traçado dessa história evolutiva podem ser baseados em termos atualísticos na costa oeste do continente norteamericano e nas ilhas em arco com subducção oblíqüa. 


\section{REFERÊNCIAS BIBLIOGRÁFICAS}

ALGARTE, J. P. (coord.) (1974) Projeto Sudeste do Estado de São Paulo : relatório final. São Paulo, DNPM/CPRM. 3 v.

ALMEIDA, F. F. M. de (1953) Considerações sobre a geomorfogênese da Serra do Cubatão. Boletim Paulista de Geografia, v.15, p. 3-17.

ALMEIDA, F.F.M. de (1955) As camadas de São Paulo e a tectônica da Serra da Cantareira. Boletim da Sociedade Brasileira de Geologia, v. 4 , n. 2, p. 23-40.

ALMEIDA, F.F.M. de (1964) Fundamentos geológicos do relevo paulista. Boletim do Instituto Geográfico e Geológico, n. 41, p. 167-263.

ALMEIDA, F.F.M. de (1969) Diferenciação tectõnica da Plataforma Brasileira. In: CONGRESSO BRASILEIRO DE GEOLOGIA, 23., Salvador, 1969. Anais. Salvador, SBG. V.1, p.29-46.

ALMEIDA, F.F.M. de (1976) The system of continental rifts bordering the Santos Basin. Anais da Academia Brasileira de Ciências, v.48 (Supl.), p. 15-26.

ALMEIDA, F.F.M. de ; HASUI, Y.; BRITO NEVES, B. B. de (1976) The Upper Precambrian of South America. Boletim IG-USP, v. 7, p. 45-80.

ALMEIDA, F.F.M. de ; HASUI, Y; CARNEIRO, C. D. R. (1975) Lineamento do Além Paraíba. Anais da Academia Brasileira de Ciências, v. 47, n. 3-4, p. 575.

ALMEIDA, J.C.H. de (2000) Zonas de cisalhamento dúctil de alto grau do Médio Vale do Rio Paraíba do Sul. Rio Claro, 190 p. Tese (Doutorado) - Instituto de Geociências e Ciências Exatas da Universidade Estadual Paulista.

ALVES, F.R. (1975) Contribuição à geologia da região de Salesópolis-Guararema, São Paulo. São Paulo, 136p. Dissertação (Mestrado) - Instituto de Geociências da Universidade de São Paulo.

ANDERSON, E.M. (1951) The dynamics of faulting and the dyke formation with applications to Britain. 2ed. Edinburgh, Oliver and Boyd. 206p.

ASSUMPÇÃO, M.; HEINTZ, M.; VAUCHEZ, a ; EGYDIO, M.; BARBOSA, J.R.; BENEVIDES, T. (2001) Upper mantle anisotropy in SE and Central Brazil from SKS. In: CONGRESSO BRASILEIRO DE GEOFÍSICA, Salvador, 2001. Anais. Salvador, SBGf, p.1-4.

BACKHEUSER, E. (1926) Breve notícia sobre a geologia do Distrito Federal, Estatística da Cidade. Anuário 1923-1924. Rio de Janeiro, v.5, n.1, p.19-131.

BJONBERG, A. J. S.; GANDOLFI, N.; PARAGUASSU, A.B. (1965) Novas observações sobre a tectônica moderna do leste de São Paulo. Revista de Engenharia Mineração e Metalurgia, v.11, n. 224, p.137-140.

BRANDALISE, L.A. (coord.) (1976) Projeto Vale do Paraíba do Sul - relatório final. Rio de Janeiro, DNPM/CPRM. $411 \mathrm{p}$.

BRAUN, O.P.G. (1972) As faixas rúpteis do Brasil. In: CONGRESSO BRASILEIRO DE GEOLOGIA, 27. (mimeografado)

CAMPANHA, G. A. da C. (1980) O Lineamento de Além - Paraíba na área de Três Rios (RJ). São Paulo, p. Dissertação ( Mestrado) - Instituto de Geociências da Universidade de São Paulo.

CAMPANHA, G. A. da C. (1981) O Lineamento de Além Paraíba na área de Três Rios, RJ. Revista Brasileira de Geociências, v. 11, n. 3, p.159-171. 
CAMPANHA, G. A. da C. (1991) Tectônica Proterozóica no Alto e Médio Vale do Ribeira, Estados de São Paulo e Paraná. São Paulo, 296 p. Tese ( Doutorado) - Instituto de Geociências Universidade de São Paulo.

CAMPANHA, G.A.da C.; GIMENEZ FILHO, A.; FERNANDES, L.A. (1983) Quadrículas Moji-Guaçu e Águas de Lindóia., São Paulo. In: PRIMEIRA JORNADA DA CARTA GEOLÓGICA DO ESTADO DE SÃO PAULO EM 1:50 000, São Paulo, 1983. Atas. São Paulo, Pró-minério. p. 137-169.

CAMPANHA, G. A. da C. ; FERRARI, A.L. (1984) O lineamento de Além Paraíba: um exemplo de zona de cisalhamento. In: CONGRESSO BRASILEIRO DE GEOLOGIA, 33., Rio de Janeiro, 1984. Roteiro de Excursão. Rio de Janeiro, SBG. v.12, p. 5425 - 5432.

CAMPANHA, G.A. da C. (coord.) (1985). Geologia das folhas Iporanga (SG.22-X-B-V-2) e Gruta do Diabo (SG.22-X-B-VI-1), Estado de São Paulo. São Paulo, IPT/Pró-Minério. (IPT. Relatório, 22. 352).

CAMPANHA, G. A. da C.; RICCOMINI, C.; MELO, M.S. de; HASUI, Y.; ALMEIDA, F.F.M. de; DEHIRA, L.K. (1985) Análise do padrão de fraturamento mesozóico-cenozóico de bacias tafrogênicas continentais do Sudeste do Brasil. In: SIMPOSIO REGIONAL DE GEOLOGIA, 5., São Paulo, 1985. Atas. São Paulo, SBG. v.1, p.337-350.

CAMPANHA, G. A. da C. ; TEIXEIRA, A. L. (1986) Nota sobre a ocorrência de um novo depósito molássico de possível idade eopaleozóica no Estado de São Paulo: Formação Quatis. Anais da Academia Brasileira de Ciências, v. 58, n. 4, p. 595.

CAMPANHA, G. A. da C.; BISTRICHI, C.A.; ALMEIDA, M.A. de. (1987) Considerações sobre a organização litoestratigráfica e evolução tectônica da faixa de dobramentos Apiaí. In: SIMPÓSIO SUL-BRASILEIRO de GEOLOGIA, 3., Curitiba, 1987. Atas. Curitiba, SBG. v.2, p.725-742.

CAMPANHA, G. A. da C. (coord.) (1988) Avaliação preliminar das geologia das folhas (em 1:50 000) Taquaral, Mina do Espírito Santo, Ribeirão Itacolomi, Serra do Aboboral, Jacupiranga (Eldorado Paulista), Rio Guaraú (Barra do Azeite), Rio Turvo (Serra do Aleixo) - Vale do Ribeira, SP. São Paulo, IPT/Pró-Minério. v. 1-4 (IPT. Relatório, 26.863).

CAMPANHA, G. A. da C. ; ENS, H. H. (1993) Estrutura geológica na região de São Sebastião. In: SIMPÓSIO DE GEOLOGIA DO SUDESTE, 3., Rio de Janeiro, 1993. Boletim de Resumos e Breves Comununicações. Rio de Janeiro, SBG. p.51-52.

CAMPANHA, G. A. da C.; ESCUDERO, O.B.; SADOWSKI, G.R. (1993). Análise da geometria e cinemática do Lineamento Ribeira, SP e PR. In: SIMPOSIO NACIONAL DE ESTUDOS TECTÕNICOS, 4., Belo Horizonte. Anais. Belo Horizonte, SBG. p.347-351.

CAMPANHA, G. A da C.; GIMENEZ FILHO, A ; SADOWSKI, G.R. (1994) Tectônica da Faixa Ribeira. In: CONGRESSO BRASILEIRO DE GEOLOGIA, 38., Balneário de Camboriú, 1978. Boletim de Resumos Expandidos. Balneário de Camboriú, SBG. v.1, p.271 - 272.

CAMPANHA, G. A. da C.; ENS, H. H.; PONÇANO, W. L. (1994) Análise morfotectônica do planalto do Juqueriquerê. Revista Brasileira de Geociências, v. 24, n. 1, p. $32-42$.

CAMPANHA, G. A. da C.; GIMENEZ FILHO, A.; BISTRICHI, C.A. (1995). Geologia da folha Itararé em 1:250 000. In: SIMPOSIO DE GEOLOGIA DO SUDESTE, 4., Águas de São Pedro, 1995. Atas. SBG, Águas de São Pedro. p.111. 
CAMPANHA, G. A. C.; SADOWSKI, G. R. (1999) Tectonics of the Southern Portion of the Ribeira Belt (Apiaí Domain). Precambrian Research, v. 98, n. 1, p. 31 - 51.

CAMPANHA, G.A. da C. (coord.) (2001) Análise da cinemática, nível crustal e fluxo de fluidos das zonas de cisalhamento da porção meridional da Faixa Apiaí. (Relatório processo Fapesp 96/5648-1).

CAMPANHA, G.A.C.; SADOWSKI, G.R. 2002. Determinações da Deformação Finita em Metassedimentos da Faixa Ribeira. Revista Brasileira de Geociências, v. 32 , no 1 (em impressão)

CAMPOS NETO, M. da C. (1999) Extensão sul do Sistema Orogênico Tocantins no contexto geodinâmico da aglutinação do Gondwana: exercício de tectônica. São Paulo, 101 p. Tese (Livre-Docência) Instituto de Geociências da Universidade de São Paulo.

CAMPOS NETO, M. da C. (2000) Orogenic systems from Southwestern Gondwana: an approach to Brasiliano - Pan African Cycle and orogenic collage in Southeastern Brazil. In: CORDANI, U.G. (ed.) Tectonic evolution of South America. Rio de Janeiro. p.335-365.

CAMPOS NETO, M.C.; BASEI, M.A.S.; ALVES, F.R.; VASCONCELOS, A.C.B. (1984a) A Nappe de Cavalgamento Socorro. In: CONGRESSO BRASILEIRO DE GEOLOGIA, 33., Rio de Janeiro, 1984. Anais. Rio de Janeiro, SBG. v. 4, p. 1809-1822.

CARNEIRO, C. D. R. (1977) Geologia e evolução geológica da Folha de São José dos Campos, SP. São Paulo, 106 p. Dissertação (Mestrado) - Instituto de Geociências, Universidade de São Paulo.

CASAS, A.M. ; GAPAIS, D. ; NALPAS, T. ; BESNARD, K. ; ROMÁN-BERDIEL, T. (2001) Analogue models of transpressive systems. Journal of Structural Geology, v. 23, p. 733-743.

CORDANI, U.G. ; DELHAL, J. ; LEDENT, D. (1973) Orogenèses supersées dans le Precambrien du Brésil Sud-oriental. Revista Brasileira de Geociências, v. 3, n. 1, p. 1-22.

CORREA NETO, A.V., DAYAN, H., VALENÇA, J.G., CABRAL, A.R. (1993). Geologia e estrutura da zona de cisalhamento do rio Paraíba do Sul e adjacências, no trecho entre Três Rios (RJ) e Sapucaia (RJ). In: SIMPÓSIO DE GEOLOGIA DO SUDESTE, 3., Rio de Janeiro, 1993. Atas. Rio de Janeiro, SBG. p.194 200.

COSTA, L.A.M. da; GOMES, B.S.; BATISTA, J.J.; MARCHETTO, C. M.L. (1978b) Carta Geológica do Estado do Rio de Janeiro, Folhas Cambuci, São Fidélis, São João do Paraíso e Italva. Rio de Janeiro, DRM.

COUTINHO, J. M. V. (1971) Pré-cambriano ao sul da cidade de São Paulo. In: CONGRESSO BRASILEIRO DE GEOLOGIA, 25., São Paulo, 1971. Roteiro das Excurções. São Paulo, SBG. Boletim Especial n. 2, p. 53-62.

COUTINHO, J.M.V. (1972) Petrologia do Pré-Cambriano em São Paulo e arredores. Boletim IG-USP, n. 3 , p.5-99.

COUTINHO, J.M.V. (1953) Petrologia da região de São Roque, São Paulo. Boletim. Faculdade de Filosofia Ciências Letras da Universidade de São Paulo. Série Mineralogia, v.159, n.11 p.1-80. São Paulo.

COUTINHO, J.M.V. (1971) O Falhamento de Cubatão. In: CONGRESSO BRASILEIRO DE GEOLOGIA, 25., São Paulo, 1971. Anais. São Paulo, SBG. Boletim Especial n. 1, p.130-131.

COWARD, M. P. (1976) Strain within ductile shear zone. Tectonophysics, v. 34, n. 3-4, p.181-197.

DAVINO, A. ; CAMPOS NETO, M. da C.; BASEI, M.A.S.; FIGUEIREDO, M.C.H. (1986) Gravimetria da região sudeste do Estado de São Paulo e considerações sobre os limites entre os cinturões móveis 
Paraíba e Ribeira. In: CONGRESSO BRASILEIRO de GEOLOGIA, 34., Goiânia., 1986. Anais. Goiânia, SBG. v. 6, p. 2673- 2683.

DE PAOR, D.G. (1983) Ortographic analysis of geological structures -I. Deformation theory. Journal of Structural Geology, v. 5 , n. 3-4, p. 255-277.

DE PAOR, D.G. (1986) Ortographic analysis of geological structures -II. Deformation theory. Journal of Structural Geology, v. 8, n. 1, p. 87-100.

DEHLER, N.M.; MACHADO, R.; VASCONCELOS, C. S. de (2000) Tectônica extensional oblíqüa no sul do Estado de São Paulo. Revista Brasileira de Geociências, v. 30, n. 4, p. 699-706.

DEHLER, N.M. (2002) Extrusão tectônica oblíqua em regime transpressivo no Cinturão Paraibides, RJ. São Paulo, 161p. Tese ( Doutorado) - Instituto de Geociências, Universidade de São Paulo.

DELHAL, J.; LEDENT, D.; CORDANI, U.G. (1969) Ages Pb/U, Sr/Rb et $\mathrm{Ar} / \mathrm{K}$ de formation metamorphiques et granitiques du sud-est du Br'esil (états de Rio de Janeiro et de Minas Gerais). Annales Sociète Geologique de Belgique, v.92, p. 271-283.

DIAS NETO, C. de M. (2001) Evolução tectono-termal do Complexo Costeiro (Faixa de Dobramentos Ribeira) em São Paulo. São Paulo, 160p. Tese ( Doutorado) - Instituto de Geociências da Universidade de São Paulo.

DIAS, R.; RIBEIRO, A. (1994) Constriction in transpressive regime: an example in the lberian branch of the Ibero-Armorican arc. Journal of Structural Geology, v. 16, p.1543-1554.

DUTTON, B.J. (1997) Finite strains in transpression zones with no boundary slip. Journal of Structural Geology, v. 19, n. 9, p.1189-1200.

EBERT, H. D.; NEVES, M. A.; HASUI, Y.; SZATMARI, P.; AIRES, J. R. (1993). Evolução dos cinturões de cisalhamento entre os blocos São Paulo, Vitória e Brasília através da tectônica colisional oblíqua: uma modelagem física. In: SIMPÓSIO NACIONAL DE ESTUDOS TECTÔNICOS, 4., Belo Horizonte, 1993. Anais. Belo Horizonte, SBG. p. 254 - 258

EBERT, H.D.; HASUI, Y. (1998) Transpresional tectonics abd strain partitioning during oblique collision between three plates in the Precambrian of southeast Brazil. In: HOLDSWORTH, R.E.;STRACHAN, R.A.; DEWEY, J.F. Continental transpressional and transtensional tectonics. London, Geological Society of London. p.231-252. (Geological Society Special Publication, n.135).

EBERT, H.D.; CHEMALE JR., F.; BABINSKI, M.; ARTUR, A.C. (1996) TECTONIC SETTING AND U/PB ZIRCON DATING OF THE PLUTONIC SOCORRO COMPLEX IN THE TRANSPRESSIVE RIO PARAÍBA DO SUL SHEAR BELT, SE BRAZIL. Tectonics, v. 15, n. 2, p. 688-699.

EBERT, H.D.; HASUI, Y.; COSTA, J.B.S. (1991). O caráter transpressivo do cinturão transcorrente Rio Paraíba do Sul. In: SIMPÓSIO NACIONAL DE ESTUDOS TECTÔNICOS, 3., Rio Claro, 1991. Boletim de Resumos Expandidos Roteiros Excursões. Rio Claro, SBG. p. 139 -141.

FALEIROS, F. M. (2000) Estratigrafia e tectônica de parte do Subgrupo Lajeado, Iporanga, SP. São Paulo, 41p. Trabalho (Conclusão de Curso) - Instituto de Geociências da Universidade de São Paulo.

FASSBINDER, E. (1990) Análise estrutural da falha da Lancinha, Estado do Paraná. São Paulo, 165 p. Dissertação (Mestrado) - Instituto de Geociências da Universidade de São Paulo. 
FASSBINDER, E. (1996) A unidade Água Clara no contexto do Grupo Açungui: um modelo transpressivo de colisão oblíqua no Neoproterozóico paranaense. São Paulo, 207. Tese ( Doutorado ) - Instituto de Geociências, Universidade de São Paulo.

FASSBINDER, E.; SADOWSKI, G.R.; FIORI, A.P. (1992) Análise estrutural da falha da Lancinha no Estado do Paraná. In: CONGRESSO BRASILEIRO DE GEOLOGIA, 37., São Paulo, 1992. Anais. São Paulo, SBG. v.2, p.362-363.

FASSBINDER, E.; SADOWSKI, G. R.; FIORI, A. P. (1994) Modelo de Riedel aplicado no Lineamento Lancinha, no Estado do Paraná. Boletim Paranaense de Geociências, v. 42, p. 173-184.

FASSBINDER, E.; FUMAGALLI, E.; FIORI, A.P. (1985) Estudo preliminar sobre os lineamentos tectônicos, intrusões e possíveis mineralizações associadas no Pré-Cambriano paranaense. In: SIMPOSIO SULBRASILEIRO GEOLOGIA, 2., Florianópolis, 1985. Atas. Florianópolis, SBG. v.1, p.172 - 183.

FIORI, A. P. (1985) Aplicação do modelo de cisalhamento simples na análise da deformação de alguns granitos paranaenses. Boletim Paranaense de Geociências, n. 36, p. 31-40.

FIORI, A. P. (1985) Avaliação preliminar do deslocamento dúctil das falhas de Lancinha e de Morro Agudo no Estado do Paraná. Boletim Paranaense de Geociências, n.36, p. 15 - 30.

FIORI, A. P. (1997) Introdução à análise da deformação. Curitiba, UFPR. 249 p.

FOSSEN, H.; TIKOFF, B. (1993) The deformation matrix for simultaneous simple shearing, pure shearing and volume change, and its application to transpression-transtension tectonics. Journal of Structural Geology, v.15, n. 3-5, p. 413-422.

FOSSEN, H.; TIKOFF, B. (1997) Forward modeling of non-steady-state deformations and the minimum strain path. Journal of Structural Geology, v.19, n.7, p. 987-996.

FOSSEN, H.; TIKOFF, B.; TEYSSIER, C. (1994) Strain modeling of tranpressional and transtensional deformation. Norsk Geologisk Tidsskrift, v.74, p. 134-145.

FRASCÁ, M.H.B.de O.; CAMPANHA, G.A. da C.; FIGUEIREDO, M.C.H. de; SADOWSKI, G.R. (1997) Geoquímica e ambiência tectônica de metabasitos do Alto e Médio Vale do Ribeira, São Paulo e Paraná. Revista Brasileira de Geociências, v.27, n. 11, p.41-48.

FRANCO, R.R. (1955). Sobre um ultramilonito com estrutura fluidal. Boletim da Sociedade Brasileira de Geologia, v.4, n.1, p.43-48.

FREITAS, R.O. de (1944) Geomorfogênese da llha de São Sebastião. Boletim. Associação dos Geógrafos Brasileiros, n.4, p. 16-30.

FREITAS, R.O. de (1947) Geologia e petrologia da llha de São Sebastião. Boletim Faculdade de Flosofia. Ciências e Letras da Universidade de São Paulo. Série Geologia, v.85 n.3, p. 1-245.

FREITAS, R.O. de (1956) Considerações sobre a tectõnica e a Geologia do Vale do Paraíba. Revista Engenharia Mineração e Metalurgia, v.24, n.143, p. 276-283.

FREITAS, R.O. de (195la) Ensaio sobre o relevo tectõnico do Brasil. Revista Brasileira de Geografia, v.13, n. 2, p. 171-222.

FREITAS, R.O. de (195lb) Relevos policíclicos na tectõnica do Escudo Brasileiro. Boletim Paulista de Geografia, v.7, p. 3-19.

FREITAS, R.O. de (1976) Definição estrutural, petrol6gica e geotectônica das cintas orogênicas antigas do Litoral Norte do Estado de São Paulo. Boletim IG-USP. São Paulo, v.1, p. 1-176. 
FRY, N. 1979. Random point distributions and strain measurements in rocks. Tectonophysics, v. 60, p. 89105.

GARCIA, M.G.M. (1996) Análise cinemática do setor de junção entre as zonas de cisalhamento direcionais São Bento do Sapucaí, Jundiuvira e Setãozinho, nas imediações de Piracaia-SP. São Paulo, 104 p. Dissertação (Mestrado) - Instituto de Geociências, Universidade de São Paulo.

GARCIA, M.G.M.; CAMPOS NETO, M.C. (1996) Evidências de inversão cinemática em zonas de cisalhamento direcionais na Faixa Ribeira, região de Piracaia-SP. In: CONGRESSO BRASILEIRO DE GEOLOGIA, 39., Salvador, 1996. Anais. Salvador, SBG. v.1, p. 442-444.

GIBBONS, W. (1994) Suspect terranes. In: HANCOCK, P.L. Continental deformation. Oxford, Pergamon Press. p.305-319.

GLAZNER, A.F.; BARTLEY, J.M. (1991) Volume loss, fluid flow and state of strain in extensional mylonites from the central Mojave Desert, California. Journal of Structural Geology, v.13, n. 5, p. 587-594.

GRESENS, R.L. (1967) Composition-volume relationships of metasomatism. Chemical Geology, v. 2, p. 4765.

HACKSPACHER, P. C. (1994) Tectônica transtensiva / transpressiva e alojamento de rochas plutônicas, a exemplo da Folha Cabreúva (SP) 1:50.000. Tese (Livre Docência) - Instituto de Geocioências e Ciências Exatas, Universidade Estadual de São Paulo)

HACKSPACHER, P.C.; MORALES, N.; ZANARDO, A.; GODOY, A.M.; OLIVEIRA, M.A.F. de; ARTUR, A.C. (1992) A tectônica transcorrente - transpressiva brasiliana da folha São Roque - SP. In: CONGRESSO BRASILEIRO DE GEOLOGIA, 37., São Paulo, 1992. Anais. São Paulo, SBG. v.2,p.348-350.

HARLAND, W.B. (1971) Tectonic transpression in Caledonian Spisbergen. Geological Magazine, v.108, n.1, p. 27-42.

HASUI, Y.; PONÇANO, W.L.; BISTRICHI, C.A.; STEIN, D.P.; GALVÃO, C.A.C. de F.; GIMENEZ, A.F.; ALMEIDA, M.A. de; MELO, M.S.; PIRES NETO, A.G. (1977) As grandes falhas do leste paulista. In: SIMPÓSIO DE GEOLOGIA REGIONAL, 1., São Paulo, 1977. Atas. São Paulo, SBG. p.369-380.

HASUI, Y. (1973) Tectônica da área das Folhas de São Roque e Pilar do Sul. São Paulo,190p. Tese (LivreDocencia) - Instituto de Geociências, Universidade de São Paulo.

HASUI, Y. (1983) Aspectos geológicos essenciais da secção Caconde -Caraguatatuba e suas implicações na reconstituição e evolução do pré- cambriano do Leste Paulista. In: JORNADA CARTA GEOLÓGICA DO ESTADO DE SÃO PAULO EM 1:50.000. São Paulo, 1983. Atas. São Paulo. p.227 - 252.

HASUI, Y. (1978) Geologia da Região Administrativa 3 (Vale do Paraíba) e parte da regíão admínístratíva 2 (lítoral)do Estado de São Paulo. São Paulo, IPT. (Monografias, Publicação IPT n. 1106).

HASUI, Y. (1989) Compartimentação estrutural e evolução tectônica do Estado de São Paulo. São Paulo, Pró-Minério. (Relatório IPT n. 27.394).

HASUI, Y.; CARNEIRO, C.D.R.; COIMBRA, A.M. (1975) The Ribeira Folded Belt. Revista Brasileira de Geociências. São Paulo, v. 5, n.4, p.257-262.

HASUI, Y.; PENALVA, F.; HENNIES, W.T. (1969). Geologia do Grupo São Roque. In: CONGRESSO BRASILEIRO DE GEOLOGIA, 23., Salvador, 1969. Anais. Salavdor, SBG. p.101-134.

HASUI,Y.; SADOWSKI, G.R. (1976) Evolução geológica do Pré- Cambriano na região sudeste do Estado de São Paulo. Revista Brasileira de Geociências, v. 6, n. 3, p.182-200. 
HEILBRON, M. (1993) Evolução tectono-metamórfica da seção Bom Jardim de Minas (MG) - Barra do Piraí (RJ) Setor central da Faixa Ribeira. São Paulo, 268p. Tese (Doutorado) Instituto de Geociências, Universidade de São Paulo.

HEILBRON, M. (1995) O segmento central da Faixa Ribeira: sintese geológica e ensaio de evolução tectônica. Rio de Janeiro, 110p. Tese ( Livre-docência) Universidade Estadual do Rio de Janeiro.

HENNIES, T.H.; HASUI, Y.; PENALVA, F. (1967) O falhamento transcorrente de Taxaquara. In: CONGRESSO BRASILEIRO DE GEOLOGIA, 21., Curitiba, 1967. Anais. Curitiba, SBG. p

HENNIES, W.T.; HASUI, Y.; PENALVA, F. (1967) O falhamento transcorrente de Taxaquara. In: CONGRESSO BRASILEIRO DE GEOLOGIA, 21., Curitiba, 1967. Anais. Curitiba, SBG p.159-168.

HUDLESTON, P. (1999). Strain compatibility and shear zones: is there a problem? Journal of Structural Geology, v. 21, p. 923-932.

JAEGER, J.C. (1969) Elasticity, fracture and flow, with engineering and geological applications. London, Methuen. 268p.

JAMES, D.E.; ASSUMPÇÃO, M. (1996) Tectonic implications of S-wave anisotropy beneath SE Brazil. Geophys. J. Int. v.126, p.1-10.

JIANG, D.; WILLIAMS, P.F. (1998). High-strain zones: a unified model. Journal of Structural Geology, v.20, n.8, p.1105-1120.

LAMEGO, A.R. (1938) 0 Massíço do Itatiaya e regiões circundantes. Boletim.Serviço Geológico Mineralógico.Departamento Nacional da Produção Mineral, n.88, p.1-93.

LAMEGO, A.R. (1946) Análise tectônica e morfológica do Sistema da Mantiqueira, Brasil. In: CONGRESSO PANAMERICANO DE ENGENHARIA DE MINAS E GEOLOGIA, 2. Petropolis, 1946. Anais. Rio de Janeiro, Est. Artes Gráficas C. Mendes Junior. v.3, p. 247-326.

LISLE, R.J. (1985) Geological strain analysis: a manual for the Rf/ $\phi$ method. Oxford, Pergamon Press. $99 p$. MACHADO, R.; DEMANGE, M. (1994) Classificação estrutural e tectônica dos granitóides neoproterozóicos do Cinturão Paraíba do Sul no Estado do Rio de Janeiro. Boletim. IG-USP. Série Cientifica, v.25, p.8196.

MACHADO, R.; ENDO, I. (1993) A megaestrutura em flor positiva do vale do rio Paraíba do Sul no Rio de Janeiro e suas implicações tectônicas regionais. In: SIMPÓSIO DE GEOLOGIA DO SUDESTE, 3., Rio de Janeiro, 1993. Atas. Rio de Janeiro, SBS. p. 208 - 213.

MALVERN, L.E. (1969) Introduction to the mechanics of a continuos medium. Englewood, Prentice-Hall . $713 p$.

MEANS, W.D. (1976) Stress and strain: basic concepts of continuum mechanics for geologists. New York, Springer-Verlag. 339p.

MERLE, O.; GAPAIS, D. (1997) Strains within thrust-wrench zones. Journal of Structural Geology v.19, n. 7, p.1011-1014.

MILTON, N.J. (1980). Determination of strain ellipsoid from measurements on any three sections. Tectonophysics, v.64, p. 19-27.

MOHANTY, S.; RAMSAY, J.G. (1994). Strain partitioning in ductile shear zones: an example from a Lower Pennine nappe of Switzerland. Journal of Structural Geology, v.16, n.5, p. 663-676.

MOORES, E.M.; TWISS, R.J. (1995) Tectonics. New York, W.H. Freeman. 415p. 
NUMmER, A. R. (2001) Geometria e cinemática de alojamento do Maciço Arrozal, Sudoeste do Estado do Rio de Janeiro. São Paulo, 169p. Tese (Doutorado) - Instituto de Geociências, Universidade de São Paulo.

NYE, J.F. (1957) Physical properties of crystals: their representation by tensors and matrices. Oxford, University Press. 322p.

ODÉ, H. (1960) Faulting as a velocity discontinuity in plastic deformation. The Geological Society of America Memoir, v. 79, p.1-382.

OERTEL, G. (1996) Stress and deformation: a handbook on tensors in geology. Oxford, University Press. $292 p$.

O'HARA, K.; BLACKBURN, W. H. (1989) Volume-loss model for trace-element enrichments in mylonites. Geolog, v. 17, p. 524-527.

PARK, R.G.; JAROSZEWSKI, W. (1994) Craton tectonics, stress and seismicity. In: HANCOCK, P.L. (ed.) Continental deformation. New York, Pergamon Press. p.200-222.

PETRI, S.; SUGUIO, K. (1969) Sobre os metassedimentos do Grupo Açungui do extremo sul do Estado de São Paulo. São Paulo, USP/DAEE. 98p.

POTDEVIN, J.L. (1993) Gresens 92: a simple Macintosh program of the Gresens method. Computers \& Geosciences, v.19, n.90, p.1229-1238.

QUINTAS, M. C. L. (1995) O embasamento da Bacia do Paraná: reconstrução geofísica de seu arcabouço. São Paulo, 213p. Tese (Doutorado) - Instituto Astronômico e Geofísico, Universidade de São Paulo.

RAMSAY, J.G. (1980) Shear zone qeometry: a review. Journal of Structural Geology, v.2, n. I/2, p.83-99.

RAMSAY, J.G.; GRAHAM, R.H. (1970) Strain variation in shear belts. Canadian Journal of Earth Sciences, v.7, p. 786-813.

RAMSAY, J.G.; HUBERT, M.I. (1983). The techniques of modern structural geology: strain analysis. New York, Academic Press. V.1

RAMSAY, J.G.; HUBERT, M.I. (1987) The techniques of modern structural geology: folds and fractures. New York, Academic Press. v.2

RAMSAY, J.G.; LISLE, R.J. (2000) The techniques of modern structural geology: Applications of continuum mechanics in structural geology. New York, Academic Press. v.3

RAMSAY, J.G. (1967). Folding and fracturing of rocks. New York, McGraw-Hill. 568 p.

RAMSAY, J.G. (1976) Displacement and strain. Philosophical Transactions Royal Society London, v.283, p.3-25.

RAMSAY, J.G. (1980). Shear zone geometry: a review. Journal of Structural Geology, v.2, n.1/2, p. 83-99.

RAMSAY, J.G.; WOOD, D.S. (1973). The geometric effects of volume change during deformational processes. Tectonophysics, v. 16, p. 263-277.

RICCOMINI, C. (1989) O Rift Continental do Sudeste do Brasil. São Paulo, 256 p. Tese ( Doutorado) Instituto de Geociências, Universidade de São Paulo.

RICHARD, P.; COBBOLD, P. (1990) Experimental insights into partitioning of fault motions in continental convergent wrench zones. Annales Tectonicae, v.4, p. 35-44.

RICHARD, P.; MOCQUET, B.; COBBOLD, P. (1991). Experiments on simultaneous faulting and folding above a basement wrench fault. Tectonophysics, v.188, p.133-141. 
RIDEG, P. (1974) Geology and structure of a portion of the Serra do Mar in Eastern São Paulo, Brazil. Binghamtom, 145p. Ph.D. Thesis, State University of New York.

ROBIN, P.; CRUDEN, A.R. (1994) Strain and vorticity patterns in ideally ductile transpression zones. Journal of Structural Geology, v. 16, n. 4, p.447-466.

ROSIER, G.F.(1965) Pesquisas geológicas na parte oriental do Estado do Rio de Janeiro e na parte vizinha do Estado de Minas Gerais. Boletim. DNPM/DGM.Rio de Janeiro, n. 222, p.1-41.

RUELLAN, F. (1944) Evolução geomorfológica da baia da Guanabara e regiões vizinhas. Revista Brasileira de Geografia, v.6, n.4, p. 445-509.

SADOWSKI, G. R.; MOTIDOME, M. J. (1987) Brazilian megafaults. Revista Geologica do Chile, v.31, p. 6175.

SADOWSKI, G. R. (1974) Tectônica da Serra do Cubatão, SP. São Paulo, 158 p. Tese (Doutorado) Instituto de Geociências, Universidade de São Paulo.

SADOWSKI, G.R.(1980) Brazilian precambrian ductile shear belts. In: CONGRES INTERNATIONAL GEOLOGIQUE, 26., Paris, 1980. Abstracts. v.1 , p.385.

SADOWSKI, G.R. (1983) Sobre a geologia estrutural de cinturões de cisalhamento continentais. São Paulo. 108 p. Tese (Livre Docência) - Instituto de Geociências, Universidade de São Paulo.

SADOWSKI, G.R. (1984) Estado da arte do tema: geologia estrutural de Grandes falhamentos. In: CONGRESSO BRASILEIRO DE GEOLOGIA, 33., Rio de Janeiro, 1984. Anais. Rio de Janeiro, SBG. p.1767-1793.

SADOWSKI, G.R. (1991) A megafalha de Cubatão no Sudeste Brasileiro. Bol. IG-USP. Série. Cienifica, v. 22, p. $15-28$.

SANDERSON, D.J.; MARCHINI, W.R.D. (1984) Transpression. Journal of Structural Geology v.6, n.5, p.449458.

SANDERSON, D.J. (1982). Models of strain variation in nappes and thrust sheets: a review. Tectonophysics, v.88, p. 201-233.

SCHREURS, G.; COLLETA, B. (1998). Analogue modelling of faulting in zones of continental transpression and transtension. In: HOLDSWORTH, R.E.; STRACHA, R.A; DEWEY, J.F. Continental transpressional and transtensional tectonics. London, Geological Society of London. p.231-252. (Geological Society Special Publication, n.135.)

SILVA, A.T.S.F. (coord.) (1977) Projeto Santos-Iguape relatório final de geologia. São Paulo, DNPM/CPRM.

SILVA, A.T.S.F.(coord.) (1981) Projeto integração e detalhe geológico no Vale do Ribeira - relatório final de integração geológica. São Paulo, DNPM/CPRM. 15 v.

SILVA, J.N.; FERRARI, P.G. (1976). Projeto Espirito Santo - relatório final. Belo Horizonte, DNPM/CPRM. $408 \mathrm{p}$.

SILVA, M. E. da (1981) Análise estrutural das faixas ectiníticas associadas ao falhamento de Cubatão entre as regiões de Juquiá e Pedro de Barros - Estado de São Paulo. São Paulo, 118p. Dissertação ( Mestrado) - Instituto de Geociências, Universidade de São Paulo.

SILVA, M.E.; MAINPRICE, D. (1999) Determination of stress directions from plagioclase fabrics in high grade deformed rocks, Além Paraíba shear zone, Ribeira fold belt, southeastern Brazil. Journal of Structural Geolog, v. 21, p.1751-1771. 
SILVA, M.E.; VAUCHEZ, A.; BASCOU, J.; HIPPERTT, J. (2002) High-temperature deformation in the Neoproterozoic transpressional Ribeira Belt, southeast Brazil. Tectonophysics 6658 (em impressão)

SILVA, M.E.; SADOWSKI, G.R.; TROMPETTE, R.R. (1982) Modelo geométrico e cinemático para os falhamentos de idade brasiliana da Faixa de Dobramentos Ribeira, Estado de São Paulo, Brasil. In: CONGRESSO LATINOAMERICANO DE GEOLOGÍA, 5., Argentina, 1982. Actas. v.2, p. 11-21

SYLVESTER, A.G.; SMITH, R.R. (1976) Tectonic transpression and basement-controlled deformation in San Andreas fault zones. Salton trough, Califórnia. American Association Petroleum Geologists Bulletin, v. 60, p. 2081-2102.

TALBOT, C.J. (1999) Ductile shear zones as counterflow boundaries in pseudoplastic fluids. Journal of Structural Geology, v. 21, p. 1535-1551.

TCHALENKO, J.S. (1970) Similarities between shear zones of different magnitudes. Geological Society of America Bulletin, v. 81, p. 1625-1640.

TEIXEIRA, A. L. (1995) Ambientes geradores dos sedimentos da Bacia Eleutério. São Paulo, 122 p. Dissertação ( Mestrado) - Instituto de Geociências, Universidade de São Paulo.

TEIXEIRA, A. L. (2000) Análise das bacias de transição Proterozóico - Fanerozóico do Estado de São Paulo e adjacências. São Paulo, 158p. Tese (Doutorado) - Instituto de Geociências, Universidade de São Paulo.

TESSIER, C.; TIKOFF, B. (1999) Fabric stability in oblique convergence and divergence. Journal of Structural Geology, v. 21, p.969-974.

TIKOFF, B.; FOSSEN, H. (1993) Simultaneous pure and simple shear: the unifying deformation matrix. Tectonophysics, v. 217, p.267-283.

TIKOFF, B.;TESSIER, C. (1994) Strain moddeling of displacement field partitioning in transpressional orogens. Journal of Structural Geology, v.16, n.11, p.1575-1588.

TROUW, R.A.J. (1995) Uma avaliação de modelos cinemáticos propostos para o megassinformal do Vale do Rio Paraíba do Sul, baseada em lineações de estiramento. In: SIMPOSIO NACIONAL DE ESTUDOS TECTONICOS, 5., Gramado, Porto Alegre, 1995. Boletim de Resumos Expandidos. São Paulo, SBG. p.103 - 104.

TROUW, R.A.J.; PACIULLO, F.V.P.; CHRISPIM, S.J.;DAYAN, H. (1982) Análise de deformação numa área de SE de Lavras, Minas Gerais. In: CONGRESSO BRASILEIRO DE GEOLOGIA, 32., Recife, 1982. Anais. Recife, SBG. v.1, p.177 - 186.

TRUESDELL, C.;TOUPIN, R.A. (1960) The classical field theories. In: FLÜGGE, S. Encyclopedia of Physics - principles of classical mechanics and field theory. Springer-Verlag. v.III/I

VASCONCELOS, C.S.; DEHLER, N.M.; YAMATO, A.A.; LOPES Jr., I.L. (1999) Projeto Jacupiaranga - Rio Guaraú. São Paulo, Secretaria de Estado de Energia/CPRM. (relatório inédito).

VAUCHEZ, A.; TOMMASI, A.; SILVA, M.E. (1994) Self-indentation of a heterogeneous continental lithosphere. Geology, v. 22, p.967-970.

VAUCHEZ, A.; TOMMASI, A.; SILVA, M.E.; TROMPETTE, R. (1992). Tectônica de escape na terminação de um craton: a Faixa Ribeira. In: CONGRESSO BRASILEIRO DE GEOLOGIA, 37., São Paulo, 1992. Boletim de Resumos Expandidos. São Paulo, SBG. p. 373 - 374. 
WASBURNE, C. (1930) Petroleum Geology of the São Paulo State, Brazil. Boletim Geografico e Geologico do Estado de São Paulo, n.22, p. 1-282.

WILSON, J.T. (1965) A new class of faults and their bearing on continental drift. Nature v. 207, n.4995, p.343-347.

WOODCOCK, N.H.; SCHUBERT, C. (1994) Continental strike-slip tectonics. In: HANCOCK, P.L. (ed.). Continental deformation. New York, Pergamon Press. p.251-263. 


\section{Agradecimentos}

Os dados discutidos neste texto foram em grande parte obtidos em projetos financiados pela FAPESP - Fundação de Amparo à Pesquisa do Estado de São Paulo, à qual o autor agradece pelo apoio fornecido.

Diversos aspectos deste trabalho foram discutidos em ocasiões anteriores com os professores Georg Robert Sadowski (IGcUSP), lan McReath (IGcUSP), Marcelo Assumpção (IAGUSP) e John W. Cosgrove (Imperial College, Londres). Algumas questões foram discutidas por E.mail com o professor Gerhard Oertel (Universidade da Califórnia, Los Angeles). Embora sem se eximir da responsabilidade por eventuais erros contidos neste texto, este autor agradece aos colegas pela pelas discussões e sugestões de rumos.

Grande parte dos trabalhos de campo realizados pelo autor nestes últimos anos na região do Vale do Ribeira foram feitos com colaboração dos então alunos de graduação Frederico Meira Faleiros e Sidney Schaberle Goveia. Este último também trabalhou com afinco na elaboração dos bancos de dados, imagens e mapas no Arclnfo. Algumas viagens e discussões de diversos aspectos da geologia regional foram feitos com os alunos de pós-graduação Carlos de Araujo, Alexandre Carnier, e Claúdio Goraieb. André Rugenski (IAG/USP) realizou a interpolação da imagem mostrada na figura 3.2. A todos o autor expressa seus sinceros agradecimentos.

Parte dos desenhos aqui apresentados foram modificados a partir de versões anteriores de Thelma Samara. As bibliotecárias Maristella Prestes Severino e Maria Aparecida Bezerra Ayello foram muito prestimosas e pacientes na formatação das referências bibliográficas. $O$ técnico Erickson Zanon muito nos ajudou na digitação de grande parte das equações utilizadas. Vera MIranda ajudou-nos na organização dos documentos. A todos o autor sinceramente agradece. 


\title{
O papel do sistema de zonas de cisalhamento transcorrentes na configuração da porção meridional da faixa ribeira
}

\author{
Ginaldo A. da C. Campanha, 2002, Livre-docência \\ Instituto de Geociências da Universidade de São Paulo
}

\begin{abstract}
ANEXO A
EXEMPLOS DE MODELAGENS DE DEFORMAÇÃO FINITA USANDO PLANILHAS DO MATHCAD
\end{abstract}

1. Introdução

2. Definições preliminares

3. Extensão de linhas

4. Sobreposição de deformações finitas

5. Cálculo dos tensores de deformação para o cisalhamento simples.

6. Zonas de cisalhamento segundo Ramsay \& Graham

7. Transpressão segundo Sanderson \& Marchini

8. Combinação de empurrão seguido de transcorrência, segundo Merle \& Gapais

9. Extrusão Lateral

10. Soterramento seguido de transcorrência

\section{Introdução}

Antes do advento dos computadores, as ferramentas matemáticas do cálculo tensorial eram de relativa pouca aplicação prática, em função do caráter extremamente laborioso das operações necessárias, envolvendo procedimentos como multiplicação e inversão de matrizes, cálculo de autovalores e autovetores, etc,

Com um microcomputador disponível, mesmo que antigo e pouco potente, estas tarefas tornam-se muito mais simples. Em qualquer linguagem de programação de alto nível (Basic, Fortran, C, Pascal, etc.), mesmo em versões antigas e para DOS, fazer operações com matrizes e cálculos repetitivos é relativamente simples.

Mesmo que não se disponha a aprender uma linguagem de programação, muitas simulações podem ser feitas com planilhas eletrônicas, disponíveis em praticamente todos os microcomputadores.

Porém existem ferramentas ainda mais fáceis de serem utilizadas, como aqueles programas voltados especificamente à realização de cálculos e modelagens matemáticas. A USP, pelo menos a época da elaboração deste trabalho, dispunha de de um número praticamente ilimitado de licenças dos pacotes comerciais MatLab, Mathcad e Mathematica. Utilizamos então neste trabalho o programa Mathcad Professional versão 8.

Dentro deste pacote, e acreditamos também que nos demais, realizar cálculos matemáticos e particularmente operações com matrizes torna-se simples, principalmente para quem já o tentou por outros meios. Obviamente existe a desvantagem deste pacotes não serem amplamente disseminados, e serem comerciais (tem de ser comprados pelo usuário interessado) 
Para definir-se uma variável, basta digitar seu nome seguido de := seguido de um valor numérico ou de uma equação qualquer, inclusive com valores simbólicos. Para se definir uma matriz o procedimento é o mesmo, bastante indicar a inserção da matriz após o sinal :=. Uma vez definidas as matrizes, as operações podem ser realizadas com a manipulação dos nomes que lhe foram atribuidos. Muitas funções já são pré-definidas. Particularmente, o cáculo de autovalores de uma matriz pode ser feito pela função eigenvals(), sendo que a matriz ou apenas seu nome devem ser especificados entre os parênteses, e a função retorna uma matriz coluna com os autovalores calculados. Similarmente, a função eigenvecs() retorna uma matriz com os co-senos diretores dos autovetores da matriz indicada. Traços retos $|F|$ indicam determinante da matriz $\mathrm{F}$.

O usuário pode também criar suas próprias funções. Neste caso, uma barra vertical após o sinal := indica os procedimentos (programa) definidos pelo usuário para aquela função.

Optamos aqui por colocar os procedimentos que desenvolvemos no Mathcad tal como aparecem no desktop (área de trabalho) do programa. Embora a formatação possa ser um pouco diferente do restante do texto desta tese, tem a vantagem de poder ser transcrito e utilizado pelo leitor tal como se encontram. Inserido no programa adequado, o texto que se segue atua como uma planilha eletrônica. Substituindo-se o valor de uma variável, todos os cálculos subsequentes (indicados à direita ou abaixo do local onde o valor foi substituido) são automaticamente realizados.

\section{Definições preliminares}

Definimos inicialmente algumas funções que utilizaremos em todos os exemplos.

Dados três valores quaisquer, as funções $A 1(), A 2()$ e $A 3()$ retornam respectivamnete o valor maior, intermediário e o menor. São necessárias porque a função eingenvals() não fornece os autovalores ordenados. As funções Rumo() e Merg() calculam respectivamente o azimute do rumo e o mergulho de uma linha, entrando-se com os seus cossenos diretores (I, $\mathrm{m}, \mathrm{n})$.

O sistema de referência adotado, assim como no restante desta tese, foi:

eixo x positivo -> Leste

eixo y positivo $\rightarrow$ Norte

eixo z positivo -> vertical para cima.

\section{Ordenação dos autovalores}

$$
A 1(a, b, c):=\left|\begin{array}{ll}
a \text { if }(a \geq b) \cdot(a \geq c) \\
b \text { if }(b \geq a) \cdot(b \geq c) \\
c \text { otherwise }
\end{array} \quad A 3(a, b, c):=\right| \begin{aligned}
& a \text { if }(a \leq b) \cdot(a \leq c) \\
& b \text { if }(b \leq a) \cdot(b \leq c) \\
& c \text { otherwise }
\end{aligned}
$$

$$
A 2(a, b, c):=\mid \begin{array}{ll}
a & \text { if }((a \leq b) \cdot(a \geq c))+((a \geq b) \cdot(a \leq c)) \\
b & \text { if }((b \leq a) \cdot(b \geq c))+((b \geq a) \cdot(b \leq c)) \\
c & \text { otherwise }
\end{array}
$$


O cálculo da orientação de uma linha em termos de azimute do rumo e mergulho, em função de seus cossenos diretores $(l, m, n)$ será:

\begin{tabular}{|c|c|c|}
\hline $\operatorname{Merg}(n):=\mid \begin{array}{l}\operatorname{asin}(n) \quad \text { if } n \geq 0 \\
-\operatorname{asin}(n) \quad \text { if } n<0\end{array}$ & $\operatorname{Rumo}(1, \mathrm{~m}, \mathrm{n}):=$ & $\begin{array}{l}1 \leftarrow-1 \text { if } \mathrm{n}>0 \\
\mathrm{~m} \leftarrow-\mathrm{m} \text { if } \mathrm{n}>0 \\
\left(3.1416+\operatorname{atan}\left(\frac{1}{\mathrm{~m}}\right)\right) \text { if }(1>0) \cdot(\mathrm{m}<0) \\
\left(3.1416+\operatorname{atan}\left(\frac{1}{\mathrm{~m}}\right)\right) \text { if }(1 \leq 0) \cdot(\mathrm{m}<0) \\
\left(2 \cdot 3.1416+\operatorname{atan}\left(\frac{1}{\mathrm{~m}}\right)\right) \text { if }(1<0) \cdot(\mathrm{m}>0) \\
\operatorname{atan}\left(\frac{1}{\mathrm{~m}}\right) \text { if }(1 \geq 0) \cdot(\mathrm{m}>0) \\
\frac{3.1416}{2} \text { if }(\mathrm{m}=0) \cdot(1>0) \\
\left(\frac{3}{2} \cdot 3.1416\right) \text { if }(\mathrm{m}=0) \cdot(1<0) \\
0 \text { if }(1=0) \cdot(\mathrm{m}=0)\end{array}$ \\
\hline
\end{tabular}

\section{Extensão de linhas}

Dada uma linha
$\mathrm{Az}:=73 \mathrm{deg}$
Plunge := 0 deg

$1:=\cos ($ Plunge $) \cdot \sin (\mathrm{Az})$

$\mathrm{m}:=\cos ($ Plunge $) \cdot \cos (\mathrm{Az})$

$\mathrm{n}:=\sin ($ Plunge $)$

$$
\mathrm{x}:=\left[\begin{array}{l}
1 \\
\mathrm{~m} \\
\mathrm{n}
\end{array}\right] \quad \mathrm{x}=\left[\begin{array}{c}
0.956 \\
0.292 \\
0
\end{array}\right]
$$

Uma matriz de transformação $F$

$$
\mathrm{F}:=\left[\begin{array}{lll}
1 & 1 & 0 \\
0 & 1 & 0 \\
0 & 0 & 1
\end{array}\right] \quad|\mathrm{F}|=1
$$

Se a linha for dada no estado inicial, sua elongação quadrática será

Tensor de Green

$$
\mathrm{C}:=\mathrm{F}^{\mathrm{T}} \cdot \mathrm{F}
$$




$$
\lambda:=\mathrm{x}^{\mathrm{T}} \cdot \mathrm{C} \cdot \mathrm{x} \quad \lambda=(1.645)
$$

Sua extensão

$$
S:=(\lambda)^{0.5} \quad S=(1.282)
$$

\section{Se a linha for dada no estado final}

Tensor de Cauchy $\quad \mathrm{c}:=\left(\mathrm{F}^{-1}\right)^{\mathrm{T}} \cdot \mathrm{F}^{-1}$

sua elongação quadrática recíproca será

$$
\Lambda:=\mathrm{x}^{\mathrm{T}} \cdot \mathrm{c} \cdot \mathrm{x}
$$

$$
\Lambda=(0.526)
$$

Elongação quadrática:

$$
\frac{1}{\Lambda}=(1.9)
$$

Extensão:

$$
\left(\frac{1}{\Lambda}\right)^{0.5}=(1.378)
$$

Cálculo da extensão de uma linha com sua orientação referida no estado final, a partir do tensor de extensão $V$ referido para seus eixos principais

Dada uma linha no estado final

$\mathrm{Az}:=135 \mathrm{deg} \quad$ Plunge $:=0 \mathrm{deg}$
$1:=\cos ($ Plunge $) \cdot \sin (\mathrm{Az})$
$\mathrm{m}:=\cos ($ Plunge $) \cdot \cos (\mathrm{Az})$
$\mathrm{n}:=\sin ($ Plunge )
$\mathrm{x}=\left[\begin{array}{c}0.956 \\ 0.292 \\ 0\end{array}\right]$

Dado um tensor de extensão referido para os seus eixos principais:

$$
\mathrm{V} 0:=\left[\begin{array}{ccc}
1.35 & 0 & 0 \\
0 & 1 & 0 \\
0 & 0 & 0.93
\end{array}\right]
$$

Dada uma matriz de transformação de coordenadas baseada nos cossenos diretores das extensões principais com relação ao sistema geográfico: 


$$
\mathrm{V} 00:=\mathrm{V}^{-1} \quad \mathrm{c} 0:=\mathrm{V} 00 \cdot \mathrm{V} 00
$$

$$
\mathrm{c}:=\mathrm{BT} \cdot \mathrm{c} 0 \cdot \mathrm{BT}^{\mathrm{T}}
$$$$
1:=\mathrm{x}^{\mathrm{T}} \cdot \mathrm{c} \cdot \mathrm{x}
$$

Elongação quadrática recíproca

$$
1=(0.847)
$$

Elongação quadrática

$$
\frac{1}{1}=(1.181)
$$

Extensão

$$
\sqrt{\frac{1}{1}}=(1.087)
$$

\section{Sobreposição de deformações finitas}

Dados

$$
\begin{array}{lll}
F 1:=\left[\begin{array}{ccc}
1 & 0 & 0 \\
0 & 2 & 0 \\
0 & 0 & 0.5
\end{array}\right] & \mathrm{F} 2:=\left[\begin{array}{lll}
1 & 2 & 0 \\
0 & 1 & 0 \\
0 & 0 & 1
\end{array}\right] & |\mathrm{F} 1|=1 \\
\mathrm{~F}:=\mathrm{F} 2 \cdot \mathrm{F} 1 & \mathrm{~F}=\left[\begin{array}{ccc}
1 & 4 & 0 \\
0 & 2 & 0 \\
0 & 0 & 0.5
\end{array}\right] & |\mathrm{F} 2|=1
\end{array}
$$

A componente simétrica no estado deformado será dada por:

$$
\mathrm{c}:=\left(\mathrm{F}^{-1}\right)^{\mathrm{T}} \cdot \mathrm{F}^{-1} \quad \mathrm{c}=\left[\begin{array}{ccc}
1 & -2 & 0 \\
-2 & 4.25 & 0 \\
0 & 0 & 4
\end{array}\right]
$$

cujos valores principais (elongações quadráticas) são:

$$
(\text { eigenvals }(\mathrm{c}))^{-1}=\left[\begin{array}{c}
20.808 \\
0.192 \\
0.25
\end{array}\right]
$$

e as extensões principais: $\quad \mathrm{S}:=(\text { eigenvals }(\mathrm{c}))^{-0.5} \quad \mathrm{~S}=\left[\begin{array}{c}4.562 \\ 0.438 \\ 0.5\end{array}\right]$

as direções principais como cossenos diretores são: 
eigenvecs $(\mathrm{c})=\left[\begin{array}{ccc}0.903 & -0.43 & 0 \\ 0.43 & 0.903 & 0 \\ 0 & 0 & 1\end{array}\right]$

Notar que o produto simétrico F.F' (Tensor de Finger) fornece os mesmos autovalores e autovetores de c, e, sendo mais simples, pode ser usado em seu lugar para esses cálculos.

$$
F \cdot F^{T}=\left[\begin{array}{ccc}
17 & 8 & 0 \\
8 & 4 & 0 \\
0 & 0 & 0.25
\end{array}\right] \quad \text { eigenvals }\left(F \cdot F^{T}\right)=\left[\begin{array}{c}
20.808 \\
0.192 \\
0.25
\end{array}\right] \quad \text { eigenvecs }\left(F \cdot F^{T}\right)=\left[\begin{array}{ccc}
0.903 & -0.43 & 0 \\
0.43 & 0.903 & 0 \\
0 & 0 & 1
\end{array}\right]
$$

As orientações das direções principais em termos de rumo e mergulho serão:

$$
\begin{aligned}
& \mathrm{S}=\left[\begin{array}{c}
4.562 \\
0.438 \\
0.5
\end{array}\right] \quad \text { AI }:=\operatorname{eigenvecs}(\mathrm{c}) \\
& \operatorname{Rumo}\left(\mathrm{AI}_{0,0}, \mathrm{AI}_{1,0}, \mathrm{AI}_{2,0}\right)=64.547 \bullet \operatorname{deg} \quad \operatorname{Merg}\left(\mathrm{AI}_{2,0}\right)=0 \bullet \operatorname{deg} \quad \mathrm{S}_{0}=4.562 \\
& \operatorname{Rumo}\left(\mathrm{AI}_{0,1}, \mathrm{AI}_{1,1}, \mathrm{AI}_{2,1}\right)=334.548 \bullet \operatorname{deg} \quad \operatorname{Merg}\left(\mathrm{AI}_{2,1}\right)=0 \bullet \operatorname{deg} \quad \mathrm{S}_{1}=0.438 \\
& \operatorname{Rumo}\left(\mathrm{AI}_{0,2}, \mathrm{AI}_{1,2}, \mathrm{AI}_{2,2}\right)=0 \text { •deg } \quad \operatorname{Merg}\left(\mathrm{AI}_{2,2}\right)=90 \text { •deg } \quad \mathrm{S}_{2}=0.5
\end{aligned}
$$

\section{Cálculo dos tensores de deformação para o cisalhamento simples.}

A matriz de transformação de coordenadas para um cisalhamento simples, com plano de cisalhamento vertical EW e deslocamento horizontal, no sistema de referência geográfico adotado, será:

$\gamma:=1.8$

$$
\mathrm{CS}:=\left[\begin{array}{ccc}
1 & \gamma & 0 \\
0 & 1 & 0 \\
0 & 0 & 1
\end{array}\right] \quad|\mathrm{CS}|=1
$$

Sendo y o valor da deformação cisalhante, positiva quando destral (sentidos anti-horários olhando-se no sentido positivo do eixo são considerados positivos; como o eixo z está orientado para cima e como o sentido destral / sinistral define-se olhando-se para baixo, inverte-se neste caso o sinal). 
A matriz de transformação de coordenadas de modo geral é uma matriz assimétrica. Pode ser decomposta em uma matriz simétrica, que representa o strain (ou seja, a distorção do corpo mais a sua variação de volume), e uma matriz assimétrica, a qual representa uma rotação de corpo rígido.

O strain pode ser obtido pelo tensores de deformação Green (C) ou de Cauchy (c). Ambos são representados por matrizes simétricas, que podem ser obtidas da matriz de transformação de coordenadas, no caso, CS, a partir das relações:

Tensores de deformação:

$$
\mathrm{C}:=\mathrm{CS}^{\mathrm{T}} \cdot \mathrm{CS} \quad \mathrm{c}:=\left(\mathrm{CS}^{-1}\right)^{\mathrm{T}} \cdot \mathrm{CS}^{-1}
$$

(Green)

( Cauchy)

$\mathrm{C}=\left[\begin{array}{ccc}1 & 1.8 & 0 \\ 1.8 & 4.24 & 0 \\ 0 & 0 & 1\end{array}\right]$

$$
\mathrm{c}=\left[\begin{array}{ccc}
1 & -1.8 & 0 \\
-1.8 & 4.24 & 0 \\
0 & 0 & 1
\end{array}\right]
$$

O cálculo dos autovetores de qualquer dessas matrizes fornecerá as direções principais de deformação; o cálculo dos autovalores fornecerá as elongações quadráticas principais.

É essencial no entanto notar que o tensor $\mathbf{C}$ refere-se aos eixos principais de deformação no estado indeformado (inicial), enquanto que os tensores c refere-se aos eixos principais no estado deformado (final).

Estado inicial (indeformado)

$$
\text { Estado final (deformado) }
$$

$$
\text { eigenvals }(C)=\left[\begin{array}{c}
0.198 \\
5.042 \\
1
\end{array}\right]
$$

$$
\text { eigenvals }(c)=\left[\begin{array}{c}
0.198 \\
5.042 \\
1
\end{array}\right]
$$

Cálculo das direções principais:

$$
\text { eigenvecs }(C)=\left[\begin{array}{ccc}
0.914 & 0.407 & 0 \\
-0.407 & 0.914 & 0 \\
0 & 0 & 1
\end{array}\right]
$$

$$
\text { eigenvecs }(c)=\left[\begin{array}{ccc}
0.914 & -0.407 & 0 \\
0.407 & 0.914 & 0 \\
0 & 0 & 1
\end{array}\right]
$$

Pode-se também obter o Tensor de Extensão (Stretch), extraindo-se a raíz quadrada de $\mathbf{C}$ ou de c. Na prática, calcula-se as extensões ("raízes quadradas das elongações quadrática", ou seja, dos autovalores de $\mathbf{C}$ ou c), colocando-as na diagonal principal de uma matriz. A vantagem dos tensores de extensão é que estes são também matrizes de transformação de coordenadas, e como tais podem ser multiplicados por outras matrizes de transformação para prescrever-se deformações sucessivas.

$$
\text { so := }(\text { eigenvals }(\mathrm{C}))^{0.5}
$$

$$
\mathrm{S}:=(\text { eigenvals }(\mathrm{c}))^{-0.5}
$$




$$
\begin{array}{ccc}
\text { so }=\left[\begin{array}{c}
0.445 \\
2.245 \\
1
\end{array}\right] & \mathrm{S}=\left[\begin{array}{c}
2.245 \\
0.445 \\
1
\end{array}\right] \\
\mathrm{U} 0:=\left[\begin{array}{ccc}
\mathrm{so}_{0} & 0 & 0 \\
0 & \mathrm{so}_{1} & 0 \\
0 & 0 & \mathrm{so}_{2}
\end{array}\right] & \mathrm{V} 0:=\left[\begin{array}{ccc}
\mathrm{S}_{0} & 0 & 0 \\
0 & \mathrm{~S}_{1} & 0 \\
0 & 0 & \mathrm{~S}_{2}
\end{array}\right] \\
\mathrm{U} 0=\left[\begin{array}{ccc}
0.445 & 0 & 0 \\
0 & 2.245 & 0 \\
0 & 0 & 1
\end{array}\right] & \mathrm{V} 0=\left[\begin{array}{ccc}
2.245 & 0 & 0 \\
0 & 0.445 & 0 \\
0 & 0 & 1
\end{array}\right]
\end{array}
$$

Os tensores U0 e V0 estão representados num sistema de coordenadas paralelas às direções principais. Para rotacioná-lo para o sistema geográfico de referência adotado, utiliza-se como matriz de transformação B a matriz dos cossenos diretores das direções principais de $\mathbf{C}$, e BT das direções principais de C.

$$
\begin{aligned}
& \text { B := eigenvecs }(\mathrm{C}) \\
& \mathrm{BT}:=\text { eigenvecs }(\mathrm{c}) \\
& \mathrm{B}=\left[\begin{array}{ccc}
0.914 & 0.407 & 0 \\
-0.407 & 0.914 & 0 \\
0 & 0 & 1
\end{array}\right] \\
& \mathrm{BT}=\left[\begin{array}{ccc}
0.914 & -0.407 & 0 \\
0.407 & 0.914 & 0 \\
0 & 0 & 1
\end{array}\right] \\
& \mathrm{U}:=\mathrm{B} \cdot \mathrm{U} 0 \cdot \mathrm{B}^{\mathrm{T}} \\
& \mathrm{V}:=\mathrm{BT} \cdot \mathrm{V0} \cdot \mathrm{BT}^{\mathrm{T}} \\
& \mathrm{U}=\left[\begin{array}{ccc}
0.743 & 0.669 & 0 \\
0.669 & 1.947 & 0 \\
0 & 0 & 1
\end{array}\right] \\
& \mathrm{V}=\left[\begin{array}{ccc}
1.947 & 0.669 & 0 \\
0.669 & 0.743 & 0 \\
0 & 0 & 1
\end{array}\right] \\
& \text { eigenvals }(U)=\left[\begin{array}{c}
0.445 \\
2.245 \\
1
\end{array}\right] \\
& \text { eigenvals }(\mathrm{V})=\left[\begin{array}{c}
2.245 \\
0.445 \\
1
\end{array}\right] \\
& \text { eigenvecs }(U)=\left[\begin{array}{ccc}
0.914 & 0.407 & 0 \\
-0.407 & 0.914 & 0 \\
0 & 0 & 1
\end{array}\right] \\
& \text { eigenvecs }(\mathrm{V})=\left[\begin{array}{ccc}
0.914 & -0.407 & 0 \\
0.407 & 0.914 & 0 \\
0 & 0 & 1
\end{array}\right]
\end{aligned}
$$

O cálculo das orientações principais em termos de azimute do rumo e mergulho, poderá ser dada por: 
ESTADO INDEFORMADO

$$
\mathrm{S}:=\text { eigenvals }(\mathrm{U})
$$

$\operatorname{Rumo}\left(\mathrm{AI}_{0,0}, \mathrm{AI}_{1,0}, \mathrm{AI}_{2,0}\right)=114.007 \bullet \operatorname{deg}$

$\operatorname{Rumo}\left(\mathrm{AI}_{0,1}, \mathrm{AI}_{1,1}, \mathrm{AI}_{2,1}\right)=24.006 \bullet \operatorname{deg}$

$\operatorname{Rumo}\left(\mathrm{AI}_{0,2}, \mathrm{AI}_{1,2}, \mathrm{AI}_{2,2}\right)=0$ •deg

\section{ESTADO DEFORMADO}

$$
\mathrm{AI}:=\text { eigenvecs }(\mathrm{V})
$$

$$
\begin{aligned}
& \operatorname{Rumo}\left(\mathrm{AI}_{0,0}, \mathrm{AI}_{1,0}, \mathrm{AI}_{2,0}\right)=65.994 \bullet \mathrm{deg} \\
& \operatorname{Rumo}\left(\mathrm{AI}_{0,1}, \mathrm{AI}_{1,1}, \mathrm{AI}_{2,1}\right)=335.994 \bullet \mathrm{deg} \\
& \operatorname{Rumo}\left(\mathrm{AI}_{0,2}, \mathrm{AI}_{1,2}, \mathrm{AI}_{2,2}\right)=0 \bullet \operatorname{deg}
\end{aligned}
$$$$
\operatorname{Merg}\left(\mathrm{AI}_{2,0}\right)=0 \bullet \operatorname{deg}
$$$$
\operatorname{Merg}\left(\mathrm{AI}_{2,1}\right)=0 \bullet \operatorname{deg}
$$$$
\operatorname{Merg}\left(\mathrm{AI}_{2,2}\right)=90 \bullet \mathrm{deg}
$$

$\mathrm{S}:=$ eigenvals $(\mathrm{V})$
$\mathrm{S}_{0}=0.445$

$\mathrm{S}_{1}=2.245$

$\operatorname{Merg}\left(\mathrm{AI}_{2,2}\right)=90 \bullet \mathrm{deg}$

$\mathrm{S}_{2}=1$

\section{Componente rotacional da deformação}

U representa os eixos de deformação no estado inicial, indeformado, e V representa-os no estado final, deformado.

Por outro lado os eixos principais equivalem às mesmas linhas físicas tanto no estado inicial como no final. Sua mudança de orientação equivale pois a uma rotação de corpo rígido.

O componente rotacional da deformação pode ser definido da seguinte forma, chamada decomposição polar:

$$
\begin{aligned}
& \mathrm{F}=\mathrm{R} \cdot \mathrm{U}=\mathrm{V} \cdot \mathrm{R} \\
& \quad \mathrm{R}=\text { matriz de rotação } \\
& \begin{aligned}
\mathrm{U} & =\text { tensor da componente simétrica direita } \\
\mathrm{V} & =\text { tensor da componente simétrica esquerda }
\end{aligned} \\
& \mathrm{U}=\left(\mathrm{F}^{\top} \cdot \mathrm{F}\right)^{1 / 2}=\mathrm{C}^{1 / 2} \\
& \mathrm{~V}=\left(\mathrm{F} \cdot \mathrm{F}^{\top}\right)^{1 / 2}=\left(\mathrm{C}^{-1}\right)^{1 / 2} \\
& \mathrm{R}=\mathrm{F} \cdot \mathrm{U}^{-1}=\mathrm{V}^{-1} \cdot \mathrm{F}
\end{aligned}
$$


$\mathrm{R}:=\mathrm{V}^{-1} \cdot \mathrm{CS}$

$$
R=\left[\begin{array}{ccc}
0.743 & 0.669 & 0 \\
-0.669 & 0.743 & 0 \\
0 & 0 & 1
\end{array}\right]
$$

ou

$$
\mathrm{R}:=\mathrm{CS} \cdot \mathrm{U}^{-1}
$$

$$
R=\left[\begin{array}{ccc}
0.743 & 0.669 & 0 \\
-0.669 & 0.743 & 0 \\
0 & 0 & 1
\end{array}\right]
$$

Que representa uma rotação em torno do eixo vertical de

$$
\mathrm{w}:=\operatorname{acos}(0.743) \quad \mathrm{w}=42.012 \bullet \operatorname{deg}
$$

De um modo geral, a matriz $R$ acima prescreve uma rotação de um ângulo $W$ em torno de uma linha $\mathrm{l}_{\mathrm{i}}$, tomando-se como positivo o sentido anti-horário visto segundo o sentido positivo do vetor representado pela linha $I_{i}$ (Oertel, 1996):

$$
\begin{aligned}
& \mathrm{w}:=\operatorname{acos}\left[\frac{\left(\mathrm{R}_{0,0}+\mathrm{R}_{1,1}+\mathrm{R}_{2,2}-1\right)}{2}\right] \quad \mathrm{w}=41.987 \cdot \mathrm{deg} \\
& 1_{0}:=\frac{\left(\mathrm{R}_{1,2}-\mathrm{R}_{2,1}\right)}{(2 \cdot \sin (\mathrm{w}))} \quad 1_{1}:=\frac{\left(\mathrm{R}_{2,0}-\mathrm{R}_{0,2}\right)}{(2 \cdot \sin (\mathrm{w}))} \\
& 1_{0}=0 \quad 1_{1}=0 \\
& \operatorname{Rumo}\left(1_{0}, 1_{1}, 1_{2}\right)=0 \bullet \frac{\left(\mathrm{R}_{0,1}-\mathrm{R}_{1,0}\right)}{(2 \cdot \sin (\mathrm{w}))}
\end{aligned}
$$

\section{Zonas de cisalhamento segundo Ramsay \& Graham}

$$
\begin{array}{lc}
\alpha=\text { encurtamento em y (NS) } & \alpha:=0.8 \\
\gamma=\text { cisalhamento vertical EW } & \gamma:=1
\end{array}
$$

$$
\begin{array}{cc}
\mathrm{D}:=\left[\begin{array}{lll}
1 & \gamma & 0 \\
0 & \alpha & 0 \\
0 & 0 & 1
\end{array}\right] & \mathrm{D}=\left[\begin{array}{ccc}
1 & 1 & 0 \\
0 & 0.8 & 0 \\
0 & 0 & 1
\end{array}\right] \\
|\mathrm{D}|=0.8 & \mathrm{~S}:=\left(\text { eigenvals }\left(\mathrm{D} \cdot \mathrm{D}^{\mathrm{T}}\right)\right)^{0.5}
\end{array}
$$




$$
\begin{array}{cc}
\text { a1 }:= & \text { A1 }\left(S_{0}, S_{1}, S_{2}\right) \quad \text { a2 }:=A 2\left(S_{0}, S_{1}, S_{2}\right) \quad \text { a3 }:=A 3\left(S_{0}, S_{1}, S_{2}\right) \\
K:=\frac{\left[\left(\frac{\mathrm{a} 1}{\mathrm{a} 2}\right)-1\right]}{\left[\left(\frac{\mathrm{a} 2}{\mathrm{a} 3}\right)-1\right]} \quad \mathrm{RS}:=\frac{\mathrm{a} 1}{\mathrm{a} 3} &
\end{array}
$$

$$
\begin{aligned}
& \text { R1 := Rumo (eigenvec } \left.\left(D \cdot D^{T}, a 1 \cdot a 1\right)_{0} \text {, eigenvec }\left(D \cdot D^{T}, a 1 \cdot a 1\right)_{1}, \operatorname{eigenvec}\left(D \cdot D^{T}, a 1 \cdot a 1\right)_{2}\right) \\
& \text { M1 }:=\operatorname{Merg}\left(\operatorname{eigenvec}\left(D \cdot D^{T}, a 1 \cdot a 1\right)_{2}\right) \\
& R 2:=\operatorname{Rumo}\left(\text { eigenvec }\left(D \cdot D^{T}, a 2 \cdot a 2\right)_{0}, \operatorname{eigenvec}\left(D \cdot D^{T}, a 2 \cdot a 2\right)_{1}, \operatorname{eigenvec}\left(D \cdot D^{T}, a 2 \cdot a 2\right)_{2}\right) \\
& \text { M2 }:=\operatorname{Merg}\left(\text { eigenvec }\left(D \cdot D^{T}, a 2 \cdot a 2\right)_{2}\right) \\
& \text { R3 }:=\operatorname{Rumo}\left(\text { eigenvec }\left(D \cdot D^{T}, a 3 \cdot a 3\right)_{0}, \text { eigenvec }\left(D \cdot D^{T}, a 3 \cdot a 3\right)_{1}, \operatorname{eigenvec}\left(D \cdot D^{T}, a 3 \cdot a 3\right)_{2}\right) \\
& \text { M3 }:=\operatorname{Merg}\left(\text { eigenvec }\left(D \cdot D^{T}, a 3 \cdot a 3\right)_{2}\right)
\end{aligned}
$$

$$
\mathrm{a} 1=1.539
$$

$$
\begin{aligned}
& \mathrm{R} 1=65.182 \bullet \text { deg } \\
& \mathrm{M} 1=0 \bullet \operatorname{deg}
\end{aligned}
$$$$
\mathrm{K}=0.584
$$

$$
\mathrm{a} 2=1
$$$$
\mathrm{R} 2=335.157 \cdot \mathrm{deg}
$$$$
\mathrm{M} 2=90 \bullet \mathrm{deg}
$$

$\mathrm{RS}=2.962$ $\mathrm{a} 3=0.52$

$$
\mathrm{R} 3=155.183 \bullet \mathrm{deg}
$$$$
\text { M3 }=0 \bullet \text { deg }
$$

Para calcular o componente de rotação:

$$
\begin{array}{ll}
\mathrm{V} 0:=\left[\begin{array}{ccc}
\mathrm{S}_{0} & 0 & 0 \\
0 & \mathrm{~S}_{1} & 0 \\
0 & 0 & \mathrm{~S}_{2}
\end{array}\right] & \mathrm{V} 0=\left[\begin{array}{ccc}
1.539 & 0 & 0 \\
0 & 0.52 & 0 \\
0 & 0 & 1
\end{array}\right] \\
\mathrm{BT}:=\text { eigenvecs }\left(\mathrm{D} \cdot \mathrm{D}^{\mathrm{T}}\right) & \mathrm{BT}=\left[\begin{array}{ccc}
0.908 & -0.42 & 0 \\
0.42 & 0.908 & 0 \\
0 & 0 & 1
\end{array}\right] \\
\mathrm{V}:=\mathrm{BT} \cdot \mathrm{V} 0 \cdot \mathrm{BT} & \mathrm{V}=\left[\begin{array}{ccc}
1.36 & 0.389 & 0 \\
0.389 & 0.699 & 0 \\
0 & 0 & 1
\end{array}\right]
\end{array}
$$




$$
\begin{aligned}
& \mathrm{R}:=\mathrm{V}^{-1} \cdot \mathrm{D} \quad \mathrm{R}=\left[\begin{array}{ccc}
0.874 & 0.486 & 0 \\
-0.486 & 0.874 & 0 \\
0 & 0 & 1
\end{array}\right] \\
& \mathrm{w}:=\operatorname{acos}\left[\frac{\left(\mathrm{R}_{0,0}+\mathrm{R}_{1,1}+\mathrm{R}_{2,2}-1\right)}{2}\right] \\
& \mathrm{w}=29.055{ }^{\bullet} \mathrm{deg} \\
& 1_{0}:=\frac{\left(\mathrm{R}_{1,2}-\mathrm{R}_{2,1}\right)}{(2 \cdot \sin (\mathrm{w}))} \\
& \mathrm{l}_{1}:=\frac{\left(\mathrm{R}_{2,0}-\mathrm{R}_{0,2}\right)}{(2 \cdot \sin (\mathrm{w}))} \\
& 1_{2}:=\frac{\left(\mathrm{R}_{0,1}-\mathrm{R}_{1,0}\right)}{(2 \cdot \sin (\mathrm{w}))} \\
& 1_{0}=0 \\
& l_{1}=0 \\
& 1_{2}=1 \\
& \operatorname{Rumo}\left(1_{0}, 1_{1}, 1_{2}\right)=0 \bullet \operatorname{deg} \quad \operatorname{Merg}\left(1_{2}\right)=90 \bullet \operatorname{deg}
\end{aligned}
$$

\section{Transpressão segundo Sanderson \& Marchini}

$$
\begin{aligned}
& \alpha=\text { extensão em } Z \text { (vertical) } \\
& \alpha:=1.4 \\
& \alpha^{-1}=\text { extensão NS (horizontal) } \\
& \gamma=\text { cisalhamento em vertical EW } \quad \gamma:=1 \\
& \mathrm{D}:=\left[\begin{array}{ccc}
1 & \alpha^{-1} \cdot \gamma & 0 \\
0 & \alpha^{-1} & 0 \\
0 & 0 & \alpha
\end{array}\right] \\
& \mathrm{D}=\left[\begin{array}{ccc}
1 & 0.714 & 0 \\
0 & 0.714 & 0 \\
0 & 0 & 1.4
\end{array}\right] \\
& \mathrm{D} \cdot \mathrm{D}^{\mathrm{T}}=\left[\begin{array}{ccc}
1.51 & 0.51 & 0 \\
0.51 & 0.51 & 0 \\
0 & 0 & 1.96
\end{array}\right] \\
& \mathrm{S}:=\left(\text { eigenvals }\left(\mathrm{D} \cdot \mathrm{D}^{\mathrm{T}}\right)\right)^{0.5} \\
& \mathrm{~A} 1(5,3,2)=5 \\
& \text { a1 }:=\mathrm{A} 1\left(\mathrm{~S}_{0}, \mathrm{~S}_{1}, \mathrm{~S}_{2}\right) \\
& \text { a2 :=A2 }\left(\mathrm{S}_{0}, \mathrm{~S}_{1}, \mathrm{~S}_{2}\right) \\
& \text { a3 }:=A 3\left(S_{0}, S_{1}, S_{2}\right) \\
& \mathrm{K}:=\frac{\left[\left(\frac{\mathrm{a} 1}{\mathrm{a} 2}\right)-1\right]}{\left[\left(\frac{\mathrm{a} 2}{\mathrm{a} 3}\right)-1\right]} \\
& \mathrm{RS}:=\frac{\mathrm{a} 1}{\mathrm{a} 3} \\
& R 1:=\operatorname{Rumo}\left(\text { eigenvec }\left(D \cdot D^{T}, a 1 \cdot a 1\right)_{0} \text {, eigenvec }\left(D \cdot D^{T}, a 1 \cdot a 1\right)_{1} \text {, eigenvec }\left(D \cdot D^{T}, a 1 \cdot a 1\right)_{2}\right) \\
& \text { M1 := Merg }\left(\text { eigenvec }\left(D \cdot D^{T}, \text { a1 } \cdot a 1\right)_{2}\right) \\
& R 2:=\operatorname{Rumo}\left(\text { eigenvec }\left(D \cdot D^{T}, a 2 \cdot a 2\right)_{0} \text {, eigenvec }\left(D \cdot D^{T}, a 2 \cdot a 2\right)_{1} \text {, eigenvec }\left(D \cdot D^{T}, a 2 \cdot a 2\right)_{2}\right)
\end{aligned}
$$




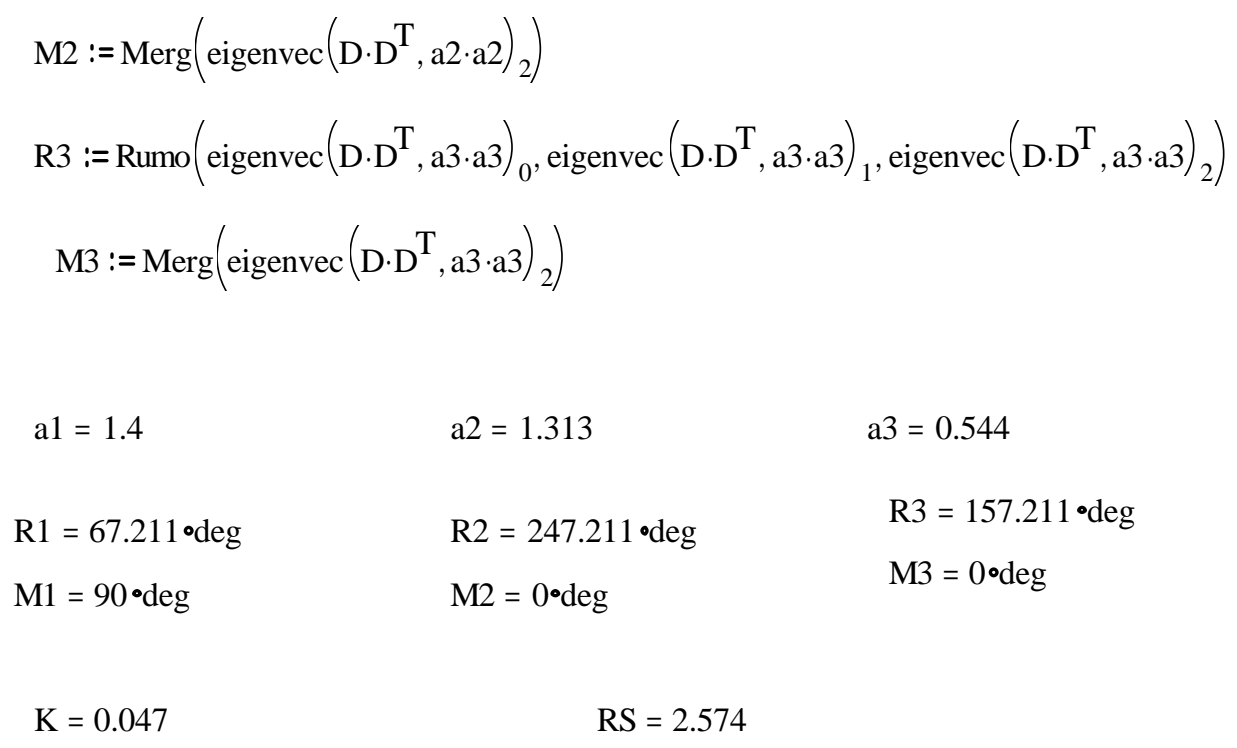

Para calcular o componente de rotação:

$$
\begin{aligned}
& \mathrm{V} 0:=\left[\begin{array}{ccc}
\mathrm{S}_{0} & 0 & 0 \\
0 & \mathrm{~S}_{1} & 0 \\
0 & 0 & \mathrm{~S}_{2}
\end{array}\right] \\
& \mathrm{V} 0=\left[\begin{array}{ccc}
1.313 & 0 & 0 \\
0 & 0.544 & 0 \\
0 & 0 & 1.4
\end{array}\right] \\
& \mathrm{BT}:=\text { eigenvecs }\left(\mathrm{D} \cdot \mathrm{D}^{\mathrm{T}}\right) \\
& \mathrm{BT}=\left[\begin{array}{ccc}
0.922 & -0.387 & 0 \\
0.387 & 0.922 & 0 \\
0 & 0 & 1
\end{array}\right] \\
& \mathrm{V}:=\mathrm{BT} \cdot \mathrm{V} 0 \cdot \mathrm{BT}^{\mathrm{T}} \\
& \mathrm{V}=\left[\begin{array}{ccc}
1.198 & 0.275 & 0 \\
0.275 & 0.659 & 0 \\
0 & 0 & 1.4
\end{array}\right] \\
& R=\left[\begin{array}{ccc}
0.923 & 0.385 & 0 \\
-0.385 & 0.923 & 0 \\
0 & 0 & 1
\end{array}\right] \\
& \mathrm{w}:=\operatorname{acos}\left[\frac{\left(\mathrm{R}_{0,0}+\mathrm{R}_{1,1}+\mathrm{R}_{2,2}-1\right)}{2}\right] \\
& \mathrm{w}=22.62 \cdot \mathrm{deg} \\
& 1_{0}:=\frac{\left(R_{1,2}-R_{2,1}\right)}{(2 \cdot \sin (w))} \\
& 1_{1}:=\frac{\left(\mathrm{R}_{2,0}-\mathrm{R}_{0,2}\right)}{(2 \cdot \sin (\mathrm{w}))} \\
& 1_{2}:=\frac{\left(\mathrm{R}_{0,1}-\mathrm{R}_{1,0}\right)}{(2 \cdot \sin (\mathrm{w}))} \\
& 1_{0}=0 \\
& 1_{1}=0 \\
& 1_{2}=1 \\
& \operatorname{Rumo}\left(1_{0}, 1_{1}, 1_{2}\right)=0 \bullet \operatorname{deg} \quad \operatorname{Merg}\left(1_{2}\right)=90 \bullet \operatorname{deg}
\end{aligned}
$$


8. Combinação de empurrão seguido de transcorrência, segundo Merle \& Gapais

$\gamma_{\mathrm{W}}:=1.5$

wrench $E / W+$ destral

$$
\mathrm{W}:=\left[\begin{array}{ccc}
1 & \gamma \mathrm{w} & 0 \\
0 & 1 & 0 \\
0 & 0 & 1
\end{array}\right]
$$

giro do plano de empurrão + anti-horario $\gamma t:=0.5$

thrust $\mathrm{N} / \mathrm{S}+$ de $\mathrm{W}$ p/ E

$$
\mathrm{T}:=\left[\begin{array}{lll}
1 & 0 & \gamma \mathrm{t} \\
0 & 1 & 0 \\
0 & 0 & 1
\end{array}\right]
$$

mergulho do plano de empurrão

$$
\begin{gathered}
\theta:=0 \text { deg } \\
\operatorname{R} \theta:=\left[\begin{array}{ccc}
\cos (\theta) & 0 & -\sin (\theta) \\
0 & 1 & 0 \\
\sin (\theta) & 0 & \cos (\theta)
\end{array}\right]
\end{gathered}
$$

$$
\begin{aligned}
& \text { wt }:=\mathrm{R} \alpha \cdot \mathrm{R} \theta \cdot \mathrm{T} \cdot \mathrm{R} \theta^{-1} \cdot \mathrm{R} \alpha^{-1} \cdot \mathrm{W} \\
& \mathrm{S}:=(\text { eigenvals }(w \mathrm{w} \cdot \mathrm{wt}))^{0.5} \\
& \mathrm{wt}=\left[\begin{array}{ccc}
1 & 1.5 & 0.433 \\
0 & 1 & -0.25 \\
0 & 0 & 1
\end{array}\right]
\end{aligned}
$$

$$
\text { a1 }:=\mathrm{A} 1\left(\mathrm{~S}_{0}, \mathrm{~S}_{1}, \mathrm{~S}_{2}\right) \quad \text { a2 }:=\mathrm{A} 2\left(\mathrm{~S}_{0}, \mathrm{~S}_{1}, \mathrm{~S}_{2}\right) \quad \text { a3 }:=\mathrm{A} 3\left(\mathrm{~S}_{0}, \mathrm{~S}_{1}, \mathrm{~S}_{2}\right)
$$

$$
\mathrm{K}:=\frac{\left[\left(\frac{\mathrm{a} 1}{\mathrm{a} 2}\right)-1\right]}{\left[\left(\frac{\mathrm{a} 2}{\mathrm{a} 3}\right)-1\right]} \quad \mathrm{RS}:=\frac{\mathrm{a} 1}{\mathrm{a} 3}
$$

$\mathrm{R} 1$ :=Rumo $\left(\right.$ eigenvec $\left(w t \cdot w t^{\mathrm{T}}, \mathrm{a} 1 \cdot \mathrm{a} 1\right)_{0}$, eigenvec $\left(w t \cdot \mathrm{wt}^{\mathrm{T}}, \mathrm{a} 1 \cdot \mathrm{a} 1\right)_{1}$, eigenvec $\left.\left(w t \cdot w \mathrm{t}^{\mathrm{T}}, \mathrm{a} 1 \cdot \mathrm{a} 1\right)_{2}\right)$

$\mathrm{M1}:=\operatorname{Merg}\left(\right.$ eigenvec $\left.\left(\mathrm{wt}^{\mathrm{w}} \cdot \mathrm{wt}^{\mathrm{T}}, \mathrm{a} 1 \cdot \mathrm{a} 1\right)_{2}\right)$

$\mathrm{R} 2:=\operatorname{Rumo}\left(\right.$ eigenvec $\left(w t \cdot w \mathrm{t}^{\mathrm{T}}, \mathrm{a} 2 \cdot \mathrm{a} 2\right)_{0}$, eigenvec $\left(w \mathrm{t} \cdot \mathrm{wt}^{\mathrm{T}}, \mathrm{a} 2 \cdot \mathrm{a} 2\right)_{1}$, eigenvec $\left.\left(w t \cdot w t^{\mathrm{T}}, \mathrm{a} 2 \cdot \mathrm{a} 2\right)_{2}\right)$

$\mathrm{M} 2:=\operatorname{Merg}\left(\right.$ eigenvec $\left.\left(w t \cdot \mathrm{wt}^{\mathrm{T}}, \mathrm{a} 2 \cdot \mathrm{a} 2\right)_{2}\right)$

$R 3:=\operatorname{Rumo}\left(\right.$ eigenvec $\left(w t \cdot w t^{T}, a 3 \cdot a 3\right)_{0}$, eigenvec $\left(w t \cdot w t^{T}, a 3 \cdot a 3\right)_{1}$, eigenvec $\left.\left(w t \cdot w t^{T}, a 3 \cdot a 3\right)_{2}\right)$

$\mathrm{M} 3:=\operatorname{Merg}\left(\right.$ eigenvec $\left.\left(w \mathrm{t} \cdot \mathrm{wt}^{\mathrm{T}}, \mathrm{a} 3 \cdot \mathrm{a} 3\right)_{2}\right)$ 

$\mathrm{a} 1=2.026$
$\mathrm{a} 2=1.09$
$\mathrm{a} 3=0.453$
$\mathrm{R} 1=245.835 \bullet \mathrm{deg}$
$\mathrm{R} 2=345.863{ }^{\circ} \mathrm{deg}$
$\mathrm{R} 3=152.986 \cdot \mathrm{deg}$
$\mathrm{M} 1=5.383 \bullet \mathrm{deg}$
$\mathrm{M} 2=61.582 \bullet \mathrm{deg}$
M3 $=27.811 \bullet \operatorname{deg}$

$\begin{array}{ll}\mathrm{K}=0.61 & \mathrm{RS}=4.477\end{array}$

Para calcular o componente de rotação:

$$
\begin{aligned}
& \mathrm{V} 0:=\left[\begin{array}{ccc}
\mathrm{S}_{0} & 0 & 0 \\
0 & \mathrm{~S}_{1} & 0 \\
0 & 0 & \mathrm{~S}_{2}
\end{array}\right] \\
& \mathrm{V} 0=\left[\begin{array}{ccc}
2.026 & 0 & 0 \\
0 & 1.09 & 0 \\
0 & 0 & 0.453
\end{array}\right] \\
& \mathrm{BT}:=\text { eigenvecs }\left(w t \cdot w t^{T}\right) \\
& \mathrm{BT}=\left[\begin{array}{ccc}
0.908 & 0.116 & -0.402 \\
0.408 & -0.461 & 0.788 \\
0.094 & 0.88 & 0.467
\end{array}\right] \\
& \mathrm{V}:=\mathrm{BT} \cdot \mathrm{V} 0 \cdot \mathrm{BT}^{\mathrm{T}} \\
& \mathrm{V}=\left[\begin{array}{ccc}
1.76 & 0.548 & 0.199 \\
0.548 & 0.85 & -0.199 \\
0.199 & -0.199 & 0.96
\end{array}\right] \\
& \mathrm{R}:=\mathrm{V}^{1} \cdot \mathrm{wt} \\
& R=\left[\begin{array}{ccc}
0.776 & 0.598 & 0.199 \\
-0.566 & 0.8 & -0.199 \\
-0.278 & 0.041 & 0.96
\end{array}\right] \\
& \mathrm{w}:=\operatorname{acos}\left[\frac{\left(\mathrm{R}_{0,0}+\mathrm{R}_{1,1}+\mathrm{R}_{2,2}-1\right)}{2}\right] \\
& \mathrm{w}=39.828 \cdot \mathrm{deg} \\
& 1_{0}:=\frac{\left(\mathrm{R}_{1,2}-\mathrm{R}_{2,1}\right)}{(2 \cdot \sin (\mathrm{w}))} \quad \mathrm{l}_{1}:=\frac{\left(\mathrm{R}_{2,0}-\mathrm{R}_{0,2}\right)}{(2 \cdot \sin (\mathrm{w}))} \quad \mathrm{l}_{2}:=\frac{\left(\mathrm{R}_{0,1}-\mathrm{R}_{1,0}\right)}{(2 \cdot \sin (\mathrm{w}))} \\
& 1_{0}=-0.187 \\
& 1_{1}=-0.373 \\
& 1_{2}=0.909 \\
& \operatorname{Rumo}\left(1_{0}, 1_{1}, 1_{2}\right)=26.674 \bullet \operatorname{deg} \quad \operatorname{Merg}\left(1_{2}\right)=65.342 \bullet \operatorname{deg}
\end{aligned}
$$




\section{Extrusão Lateral}

$$
\begin{aligned}
& \alpha=\text { extensão em EW (horizontal) } \quad \alpha:=10 \\
& \alpha-1=\text { extensão em NS (horizontal) } \\
& \gamma=\text { cisalhamento em vertical EW } \quad::=1.1 \\
& \mathrm{E}:=\left[\begin{array}{ccc}
\alpha & 0 & 0 \\
0 & \alpha^{-1} & 0 \\
0 & 0 & 1
\end{array}\right] \quad \text { CS }:=\left[\begin{array}{lll}
1 & \gamma & 0 \\
0 & 1 & 0 \\
0 & 0 & 1
\end{array}\right] \\
& \mathrm{D}=\left[\begin{array}{ccc}
10 & 0.11 & 0 \\
0 & 0.1 & 0 \\
0 & 0 & 1
\end{array}\right] \quad \mathrm{D}:=\mathrm{CS} \cdot \mathrm{E}
\end{aligned}
$$

$R 1$ :=Rumo $\left(\right.$ eigenvec $\left(D \cdot D^{T}, a 1 \cdot a 1\right)_{0}$, eigenvec $\left(D \cdot D^{T}, a 1 \cdot a 1\right)_{1}$, eigenvec $\left.\left(D \cdot D^{T}, a 1 \cdot a 1\right)_{2}\right)$

$M 1:=\operatorname{Merg}\left(\right.$ eigenvec $\left.\left(D \cdot D^{T}, \text { a } 1 \cdot a 1\right)_{2}\right)$

$R 2$ : = Rumo (eigenvec $\left(D \cdot D^{T}, a 2 \cdot a 2\right)_{0}$, eigenvec $\left(D \cdot D^{T}, a 2 \cdot a 2\right)_{1}$, eigenvec $\left.\left(D \cdot D^{T}, a 2 \cdot a 2\right)_{2}\right)$

$\mathrm{M} 2:=\operatorname{Merg}\left(\right.$ eigenvec $\left.\left(D \cdot D^{T}, \mathrm{a} 2 \cdot \mathrm{a} 2\right){ }_{2}\right)$

$R 3$ :=Rumo $\left(\right.$ eigenvec $\left(D \cdot D^{T}, a 3 \cdot a 3\right)_{0}$, eigenvec $\left(D \cdot D^{T}, a 3 \cdot a 3\right)_{1}$, eigenvec $\left.\left(D \cdot D^{T}, a 3 \cdot a 3\right)_{2}\right)$

$$
M 3:=\operatorname{Merg}\left(\text { eigenvec }\left(D \cdot D^{T}, a 3 \cdot a 3\right)_{2}\right)
$$
$\mathrm{a} 1=10.001$
$\mathrm{a} 2=1$
$\mathrm{a} 3=0.1$

$\mathrm{R} 1=89.994 \cdot \mathrm{deg}$

$\mathrm{R} 2=359.995{ }^{\circ} \mathrm{deg}$

$\mathrm{R} 3=179.994 \cdot \mathrm{deg}$

M1 = 0•deg

$\mathrm{M} 2=90 \bullet \mathrm{deg}$

$\mathrm{M} 3=0 \bullet$ deg

$\mathrm{K}=1$

$\mathrm{RS}=100.012$ 
Para calcular o componente de rotação:

$$
\begin{aligned}
& \mathrm{V} 0:=\left[\begin{array}{ccc}
\mathrm{S}_{0} & 0 & 0 \\
0 & \mathrm{~S}_{1} & 0 \\
0 & 0 & \mathrm{~S}_{2}
\end{array}\right] \\
& \mathrm{V} 0=\left[\begin{array}{ccc}
10.001 & 0 & 0 \\
0 & 0.1 & 0 \\
0 & 0 & 1
\end{array}\right] \\
& \text { BT := eigenvecs }\left(D \cdot D^{T}\right) \\
& \mathrm{BT}=\left[\begin{array}{ccc}
1 & -1.1 \cdot 10^{-4} & 0 \\
1.1 \cdot 10^{-4} & 1 & 0 \\
0 & 0 & 1
\end{array}\right] \\
& \mathrm{V}:=\mathrm{BT} \cdot \mathrm{VO} \cdot \mathrm{BT}^{\mathrm{T}} \\
& \mathrm{V}=\left[\begin{array}{ccc}
10.001 & 1.089 \cdot 10^{-3} & 0 \\
1.089 \cdot 10^{-3} & 0.1 & 0 \\
0 & 0 & 1
\end{array}\right] \\
& R=\left[\begin{array}{ccc}
1 & 0.011 & 0 \\
-0.011 & 1 & 0 \\
0 & 0 & 1
\end{array}\right] \\
& \mathrm{w}:=\operatorname{acos}\left[\frac{\left(\mathrm{R}_{0,0}+\mathrm{R}_{1,1}+\mathrm{R}_{2,2}-1\right)}{2}\right] \\
& \mathrm{w}=0.624 \bullet \mathrm{deg} \\
& 1_{0}:=\frac{\left(R_{1,2}-R_{2,1}\right)}{(2 \cdot \sin (w))} \\
& 1_{1}:=\frac{\left(\mathrm{R}_{2,0}-\mathrm{R}_{0,2}\right)}{(2 \cdot \sin (\mathrm{w}))} \\
& 1_{2}:=\frac{\left(\mathrm{R}_{0,1}-\mathrm{R}_{1,0}\right)}{(2 \cdot \sin (\mathrm{w}))} \\
& 1_{0}=0 \\
& l_{1}=0 \\
& \operatorname{Rumo}\left(1_{0}, 1_{1}, 1_{2}\right)=0 \bullet \operatorname{deg} \\
& \operatorname{Merg}\left(1_{2}\right)=90-1.708 i \cdot 10^{-5} \bullet \operatorname{deg}
\end{aligned}
$$

\section{Soterramento seguido de transcorrência}

$\alpha=$ extensão em $Z$ (vertical)

$$
\alpha:=0.8
$$

$\gamma=$ cisalhamento em vertical $\mathrm{EW}$

$$
\gamma:=1
$$




$$
\begin{aligned}
& \mathrm{D}:=\left[\begin{array}{lll}
1 & \gamma & 0 \\
0 & 1 & 0 \\
0 & 0 & \alpha
\end{array}\right] \\
& \mathrm{D}=\left[\begin{array}{ccc}
1 & 1 & 0 \\
0 & 1 & 0 \\
0 & 0 & 0.8
\end{array}\right] \\
& \mathrm{D} \cdot \mathrm{D}^{\mathrm{T}}=\left[\begin{array}{ccc}
2 & 1 & 0 \\
1 & 1 & 0 \\
0 & 0 & 0.64
\end{array}\right] \\
& \mathrm{S}:=\left(\text { eigenvals }\left(\mathrm{D} \cdot \mathrm{D}^{\mathrm{T}}\right)\right)^{0.5} \\
& \text { a1 :=A1 }\left(\mathrm{S}_{0}, \mathrm{~S}_{1}, \mathrm{~S}_{2}\right) \\
& \text { a2 }:=\mathrm{A} 2\left(\mathrm{~S}_{0}, \mathrm{~S}_{1}, \mathrm{~S}_{2}\right) \\
& \mathrm{a} 3:=\mathrm{A} 3\left(\mathrm{~S}_{0}, \mathrm{~S}_{1}, \mathrm{~S}_{2}\right) \\
& \mathrm{K}:=\frac{\left[\left(\frac{\mathrm{a} 1}{\mathrm{a} 2}\right)-1\right]}{\left[\left(\frac{\mathrm{a} 2}{\mathrm{a} 3}\right)-1\right]} \\
& \mathrm{RS}:=\frac{\mathrm{a} 1}{\mathrm{a} 3} \\
& R 1:=\operatorname{Rumo}\left(\text { eigenvec }\left(D \cdot D^{T}, a 1 \cdot a 1\right)_{0} \text {, eigenvec }\left(D \cdot D^{T}, a 1 \cdot a 1\right)_{1} \text {, eigenvec }\left(D \cdot D^{T}, a 1 \cdot a 1\right)_{2}\right) \\
& \text { M1 := Merg }\left(\text { eigenvec }\left(D \cdot D^{T}, a 1 \cdot a 1\right)_{2}\right) \\
& \mathrm{R} 2:=\operatorname{Rumo}\left(\text { eigenvec }\left(D \cdot D^{T}, a 2 \cdot a 2\right)_{0}, \text { eigenvec }\left(D \cdot D^{T}, a 2 \cdot a 2\right)_{1} \text {, eigenvec }\left(D \cdot D^{T}, a 2 \cdot a 2\right)_{2}\right) \\
& M 2:=\operatorname{Merg}\left(\text { eigenvec }\left(D \cdot D^{T}, a 2 \cdot a 2\right)_{2}\right) \\
& R 3:=\operatorname{Rumo}\left(\text { eigenvec }\left(D \cdot D^{T}, a 3 \cdot a 3\right)_{0} \text {, eigenvec }\left(D \cdot D^{T}, a 3 \cdot a 3\right)_{1} \text {, eigenvec }\left(D \cdot D^{T}, a 3 \cdot a 3\right)_{2}\right) \\
& \text { M3 := Merg }\left(\text { eigenvec }\left(D \cdot D^{T}, a 3 \cdot a 3\right){ }_{2}\right) \\
& \mathrm{a} 1=1.618 \\
& \mathrm{a} 2=0.8 \\
& \mathrm{a} 3=0.618 \\
& \mathrm{R} 1=58.283 \cdot \mathrm{deg} \\
& \mathrm{R} 2=328.283 \cdot \mathrm{deg} \\
& \mathrm{R} 3=148.283^{\circ} \mathrm{deg} \\
& \text { M1 }=0 \text { •deg } \\
& \mathrm{M} 2=90^{\circ} \mathrm{deg} \\
& \mathrm{M} 3=0 \bullet \operatorname{deg}
\end{aligned}
$$


ANEXO B

Tabelas de dados litoquímicos 
Anexo B - Resultados de análises químicas

\begin{tabular}{|c|c|c|c|c|c|c|c|c|c|}
\hline SAMPLE & AP126B & AP136 & F036 & GD109A & GD177 & GD248 & GD252B & GD391B & GD391G \\
\hline $\mathrm{SiO} 2$ & 50.42 & 49.12 & 53.4 & \begin{tabular}{|l|}
47.55 \\
\end{tabular} & \begin{tabular}{|l|}
50.09 \\
\end{tabular} & 51.12 & 46.39 & 46.87 & 45.36 \\
\hline $\mathrm{Al} 2 \mathrm{O} 3$ & 14.29 & 14.37 & 14.1 & 13.13 & 14.48 & 19.72 & 14.85 & 15.94 & 14.58 \\
\hline $\mathrm{Fe} 2 \mathrm{O} 3$ & 11.6 & 11.27 & 13.74 & 12.6 & 10.21 & 10.13 & 12.38 & 8.62 & 14.82 \\
\hline $\mathrm{MnO}$ & 0.21 & 0.167 & 0.181 & 0.196 & 0.135 & 0.197 & 0.169 & 0.176 & 0.243 \\
\hline $\mathrm{MgO}$ & 7.3 & 6.99 & 5.6 & 11.42 & 8.98 & 4.72 & 5.66 & 9.73 & 7.92 \\
\hline $\mathrm{CaO}$ & 7.71 & 11.1 & 7.19 & 10.45 & 9.77 & 1.88 & 4.33 & 15.96 & 11.52 \\
\hline $\mathrm{Na2O}$ & 2.86 & 2.18 & 3.27 & 1.51 & 2.73 & 4.19 & 2.58 & 0.75 & 1.83 \\
\hline K2O & 0.08 & 0.05 & 0.05 & 0.11 & 0.25 & 4.13 & 2.16 & 0.18 & 0.23 \\
\hline TiO2 & 1.383 & 1.452 & 1.412 & 0.971 & 0.483 & 1.111 & 2.394 & 0.37 & 0.957 \\
\hline P2O5 & 0.1 & 0.17 & 0.2 & 0.06 & 0.04 & 0.21 & 0.37 & 0.03 & 0.08 \\
\hline LOI & 3.01 & 1.76 & 1.31 & 1.63 & 2.58 & 3.19 & 6.46 & 2.29 & 2.35 \\
\hline TOTAL & 98.96 & 98.63 & 100.44 & 99.63 & 99.77 & 100.58 & 97.73 & 100.9 & 99.9 \\
\hline Sc & 48 & 36 & 38 & 41 & 41 & 19 & 31 & 47 & 37 \\
\hline $\mathrm{V}$ & 333.9168 & 298.0189 & 365.7472 & 269.3245 & 192.8142 & 128.879 & 229.8432 & 202.2722 & 271.3625 \\
\hline $\mathrm{Cr}$ & 272.648 & 189.3894 & 0 & 569.37 & 321.0189 & 97.21688 & 75.50589 & 276.9283 & 23.90291 \\
\hline Co & 35.59233 & 32.24383 & 36.28362 & 54.62824 & 46.06457 & 23.64344 & 35.8797 & 40.81272 & 56.69144 \\
\hline $\mathrm{Ni}$ & 127.5607 & 138.1491 & 61.54332 & 233.0101 & 158.0988 & 68.70735 & 66.1076 & 153.7492 & 113.1556 \\
\hline $\mathrm{Cu}$ & 105.2981 & 73.22599 & 129.023 & 128.7045 & 30.19355 & 0 & 43.4551 & 29.46596 & 38.50188 \\
\hline $\mathrm{Zn}$ & 0 & 60.62983 & 66.67979 & 51.71253 & 58.29996 & 132.5792 & 72.90138 & 56.18116 & 107.6931 \\
\hline $\mathrm{Ga}$ & 16.12748 & 17.3699 & 20.99046 & 15.7972 & 11.74156 & 27.36174 & 20.88503 & 15.52287 & 18.30345 \\
\hline As & 0 & 0 & 0 & 0 & 0 & 0 & 0 & 0 & 6.615543 \\
\hline $\mathrm{Rb}$ & 3.100946 & 0 & 0 & 0 & 10.44597 & 112.3688 & 114.1915 & 14.32653 & 19.19854 \\
\hline $\mathrm{Sr}$ & 340.0264 & 312.5549 & 294.2297 & 152.9845 & 144.1787 & 168.4207 & 274.9703 & 206.9245 & 362.9551 \\
\hline $\bar{Y}$ & 23.43063 & 19.36533 & 30.22059 & 13.63993 & 8.314733 & 39.76573 & 45.10801 & 8.380551 & 14.48542 \\
\hline$Z r$ & 80.59191 & 106.8112 & 142.4717 & 45.16222 & 23.06664 & 280.762 & 247.6268 & 16.00502 & 49.01309 \\
\hline $\mathrm{Nb}$ & 6.540302 & 9.218115 & 9.136632 & 3.155891 & 1.255049 & 22.12121 & 4.745917 & 0.799765 & 2.954615 \\
\hline Cs & 0.294641 & 0 & 0.117869 & 0 & 0.383507 & 2.044564 & 9.829762 & 0.39096 & 0.453393 \\
\hline $\mathrm{Ba}$ & 14.57561 & 14.71977 & 31.85166 & 16.5834 & 36.04932 & 1190 & 681.1166 & 18.02893 & 45.90548 \\
\hline $\mathrm{La}$ & 9.292736 & 9.720902 & 6.615257 & 2.817132 & 1.11345 & 27.16643 & 11.70987 & 1.684167 & 3.055454 \\
\hline $\mathrm{Ce}$ & 18.86667 & 21.76665 & 13.98856 & 6.419316 & 3.022929 & 54.07585 & 32.87526 & 2.737497 & 7.902392 \\
\hline $\mathrm{Pr}$ & 2.919751 & 3.036939 & 2.246018 & 1.09444 & 0.439974 & 5.851081 & 4.928489 & 0.485137 & 1.161962 \\
\hline $\mathrm{Nd}$ & 13.58894 & 14.73358 & 11.41955 & 5.828043 & 2.531739 & 23.53146 & 25.23501 & 2.68547 & 6.186773 \\
\hline Sm & 3.684246 & 3.59395 & 3.64271 & 1.873249 & 0.862179 & 4.630229 & 6.778846 & 0.902449 & 1.917952 \\
\hline$\overline{\mathrm{Eu}}$ & 1.568261 & 1.324015 & 1.548344 & 0.734763 & 0.375445 & 1.316098 & 2.51433 & 0.485879 & 0.866986 \\
\hline$\overline{G d}$ & 3.820323 & 3.754278 & 4.398837 & 2.129718 & 1.170303 & 4.440678 & 7.047724 & 1.271696 & 2.213321 \\
\hline $\mathrm{Tb}$ & 0.728649 & 0.632314 & 0.834627 & 0.406696 & 0.212073 & 0.874819 & 1.296989 & 0.22915 & 0.427903 \\
\hline Dy & 4.408521 & 3.766123 & 5.28142 & 2.545038 & 1.409428 & 5.854535 & 8.126742 & 1.440213 & 2.716537 \\
\hline $\mathrm{Ho}$ & 0.833133 & 0.694847 & 1.0552 & 0.496198 & 0.301761 & 1.289168 & 1.600261 & 0.282339 & 0.53675 \\
\hline $\mathrm{Er}$ & 2.440969 & 1.992986 & 3.055897 & 1.465185 & 0.922492 & 4.132068 & 4.67979 & 0.816671 & 1.602025 \\
\hline Tm & 0.35664 & 0.275223 & 0.448197 & 0.205032 & 0.138824 & 0.690559 & 0.700659 & 0.112206 & 0.228293 \\
\hline$\overline{Y b}$ & 2.278815 & 1.66648 & 2.727948 & 1.334664 & 0.951057 & 4.686741 & 4.535262 & 0.732212 & 1.558114 \\
\hline $\mathrm{Lu}$ & 0.312237 & 0.239434 & 0.381982 & 0.195774 & 0.136246 & 0.683758 & 0.651899 & 0.104951 & 0.209695 \\
\hline $\mathrm{Hf}$ & 2.16445 & 2.674324 & 3.551515 & 1.232109 & 0.680118 & 6.877285 & 5.477179 & 0.458315 & 1.313277 \\
\hline $\mathrm{Ta}$ & 0.47374 & 0.652629 & 0.853118 & 0.16811 & 0 & 2.062919 & 0.321406 & 0 & 0.172523 \\
\hline $\mathrm{Pb}$ & 0 & 0 & 6.493822 & 0 & 5.758148 & 22.08781 & 0 & 8.268377 & 15.93271 \\
\hline Th & 0.902648 & 0.92607 & 1.721545 & 0.17081 & 0.133728 & 9.111878 & 0.611375 & 0.111145 & 0.214502 \\
\hline $\mathrm{U}$ & 0.225389 & 0.243845 & 0.334441 & 0.072619 & 0 & 2.1612 & 0.126409 & 0 & 0.07778 \\
\hline $\mathrm{d}$ & 2.830481 & 3.021637 & 2.882045 & 3.043803 & 2.939064 & 2.822016 & 2.80986 & 3.144117 & 3.086426 \\
\hline \multicolumn{10}{|c|}{ Eliminados: Be Ge Mo Ag In Sn Sb W TI Bi demais - zerados } \\
\hline \multicolumn{3}{|c|}{ Ba Y V Zr Sr : adotado ICP/MS } & & & & & & & \\
\hline
\end{tabular}


Anexo B - continuação

\begin{tabular}{|c|c|c|c|c|c|c|c|c|c|}
\hline SAMPLE & GD396D & GD456 & GD486A & GD487 & GD522B & GD537 & GD541 & GD709 & IP037B \\
\hline $\mathrm{SiO} 2$ & 33.82 & 48.41 & 49.21 & 42.72 & 49.31 & 48.5 & 49.08 & 62.72 & 46.03 \\
\hline $\mathrm{Al} 2 \mathrm{O} 3$ & 14.79 & 14.1 & 14.38 & 11.93 & 13.18 & 13.69 & 13.76 & 11.21 & 14.17 \\
\hline $\mathrm{Fe} 2 \mathrm{O} 3$ & 13.03 & 11.03 & 11.34 & 12.9 & 14.95 & 8.57 & 12.42 & 12.76 & 13.31 \\
\hline $\mathrm{MnO}$ & 0.286 & 0.157 & 0.166 & 0.194 & 0.173 & 0.16 & 0.19 & 0.205 & 0.186 \\
\hline $\mathrm{MgO}$ & 8.87 & 7.08 & 7.32 & 5.6 & 5.86 & 10.38 & 6.39 & 3.56 & 8.71 \\
\hline $\mathrm{CaO}$ & 8.25 & 11.89 & 11.94 & 9.36 & 8.83 & 13.29 & 11.42 & 2.27 & 11.67 \\
\hline $\mathrm{Na2O}$ & 3.2 & 2.09 & 2.12 & 2.49 & 1.67 & 0.93 & 1.76 & 3.16 & 1.92 \\
\hline K2O & 0.21 & 0.34 & 0.21 & 0.05 & 0.22 & 0.54 & 0.17 & 0.13 & 0.11 \\
\hline TiO2 & 1.275 & 1.476 & 1.573 & 1.935 & 1.498 & 0.3 & 1.228 & 0.401 & 1.179 \\
\hline $\mathrm{P} 2 \mathrm{O5}$ & 0.13 & 0.13 & 0.16 & 0.16 & 0.13 & 0.03 & 0.1 & 0.16 & 0.1 \\
\hline LOI & 15.05 & 1.82 & 1.7 & 11.47 & 3.5 & 2.24 & 2.15 & 2.04 & 3.14 \\
\hline TOTAL & 98.9 & 98.55 & 100.11 & 98.8 & 99.32 & 98.61 & 98.67 & 98.6 & 100.52 \\
\hline Sc & 41 & 36 & 36 & 32 & 50 & 51 & 42 & 10 & 42 \\
\hline V & 294.9935 & 314.1996 & 313.5642 & 354.7473 & 402.0619 & 185.8155 & 319.8634 & 80.82599 & 314.6635 \\
\hline $\mathrm{Cr}$ & 223.589 & 248.6796 & 237.2862 & 72.92452 & 80.28798 & 60.42576 & 91.60864 & 47.60457 & 248.7273 \\
\hline Co & 23.96945 & 33.38639 & 34.34259 & 37.46214 & 40.17957 & 33.71928 & 33.45258 & 17.10833 & 42.79301 \\
\hline $\mathrm{Ni}$ & 114.4751 & 141.3428 & 125.8352 & 91.76527 & 73.93515 & 90.42339 & 69.84297 & 32.62538 & 166.3549 \\
\hline $\mathrm{Cu}$ & 73.80089 & 100.4039 & 109.3734 & 91.36844 & 139.0736 & 42.19511 & 33.96542 & 34.19201 & 94.62963 \\
\hline $\mathrm{Zn}$ & 138.3144 & 63.90012 & 38.55963 & 97.87101 & 65.36334 & 53.88635 & 0 & 39.0035 & 81.46701 \\
\hline $\mathrm{Ga}$ & 20.3268 & 19.04593 & 18.01149 & 18.87524 & 18.77685 & 12.03887 & 16.40428 & 15.93983 & 18.37413 \\
\hline As & 33.94958 & 0 & 12.34346 & 0 & 0 & 0 & 0 & 0 & 10.94992 \\
\hline $\mathrm{Rb}$ & 9.218149 & 8.448823 & 5.521678 & 2.789827 & 36.67281 & 21.36613 & 4.959527 & 2.673139 & 4.001599 \\
\hline $\mathrm{Sr}$ & 292.2681 & 385.4946 & 402.3629 & 422.1383 & 137.6533 & 75.8904 & 159.9981 & 198.1771 & 223.8977 \\
\hline $\mathrm{Y}$ & 20.27093 & 19.10559 & 19.78029 & 21.69124 & 26.91081 & 8.464075 & 24.8501 & 33.72441 & 18.04181 \\
\hline Zr & 86.91375 & 100.0251 & 104.6798 & 130.6772 & 86.25218 & 17.43752 & 64.04533 & 97.52093 & 63.87191 \\
\hline $\mathrm{Nb}$ & 5.443138 & 9.464059 & 9.97443 & 14.16309 & 5.200816 & 0.687637 & 5.020486 & 8.421235 & 4.112326 \\
\hline Cs & 1.316128 & 0.202649 & 0.277942 & 1.171018 & 1.295293 & 0.540853 & 0.12784 & 0.600461 & 0.813124 \\
\hline $\mathrm{Ba}$ & 82.74825 & 79.40889 & 54.03488 & 56.02381 & 49.80442 & 91.69414 & 53.37314 & 185.7781 & 42.95727 \\
\hline $\mathrm{La}$ & 4.101359 & 10.11892 & 10.16962 & 13.7002 & 6.89048 & 1.106691 & 6.381808 & 22.229 & 3.775229 \\
\hline $\mathrm{Ce}$ & 10.91306 & 23.31273 & 23.5864 & 31.71874 & 13.47198 & 2.701846 & 15.57175 & 53.76737 & 9.953993 \\
\hline $\mathrm{Pr}$ & 1.618953 & 3.162179 & 3.113166 & 4.166114 & 2.523234 & 0.361782 & 2.029504 & 5.469703 & 1.474283 \\
\hline $\mathrm{Nd}$ & 8.589922 & 15.27888 & 14.62511 & 19.09999 & 11.8286 & 1.965521 & 9.77451 & 21.49965 & 7.774012 \\
\hline Sm & 2.602359 & 3.862108 & 3.739486 & 4.577793 & 3.465342 & 0.653653 & 2.867288 & 4.266541 & 2.410162 \\
\hline $\mathrm{Eu}$ & 0.825352 & 1.447037 & 1.396455 & 1.708043 & 1.439679 & 0.314796 & 1.169338 & 1.055578 & 1.019218 \\
\hline Gd & 3.04522 & 3.773927 & 3.692556 & 4.519718 & 3.921608 & 1.007208 & 3.358932 & 4.535379 & 2.760684 \\
\hline $\mathrm{Tb}$ & 0.595271 & 0.663385 & 0.638211 & 0.776827 & 0.766162 & 0.195202 & 0.642768 & 0.723364 & 0.528677 \\
\hline Dy & 3.831235 & 3.964306 & 3.774887 & 4.510972 & 4.962627 & 1.382019 & 4.174434 & 4.433431 & 3.235682 \\
\hline $\mathrm{Ho}$ & 0.74548 & 0.738549 & 0.709597 & 0.850162 & 0.989237 & 0.300927 & 0.849646 & 0.945719 & 0.642134 \\
\hline $\mathrm{Er}$ & 2.205124 & 2.12477 & 2.039643 & 2.361579 & 3.023714 & 0.920182 & 2.569093 & 2.905116 & 1.857329 \\
\hline Tm & 0.32795 & 0.307094 & 0.287716 & 0.33274 & 0.450152 & 0.137126 & 0.379044 & 0.448649 & 0.265562 \\
\hline $\mathrm{Yb}$ & 2.058705 & 1.912261 & 1.802743 & 2.034139 & 2.844869 & 0.977403 & 2.334695 & 2.718325 & 1.648237 \\
\hline$\overline{\mathrm{Lu}}$ & 0.298397 & 0.263915 & 0.255013 & 0.302132 & 0.399707 & 0.137131 & 0.341921 & 0.39545 & 0.238522 \\
\hline $\mathrm{Hf}$ & 2.259734 & 2.772698 & 2.684233 & 3.495724 & 2.337828 & 0.479308 & 1.825535 & 2.471506 & 1.645249 \\
\hline $\mathrm{Ta}$ & 0.34753 & 0.70577 & 0.711234 & 1.102121 & 0.33493 & 0 & 0.265512 & 0.602774 & 0.240924 \\
\hline $\mathrm{Pb}$ & 8.19682 & 0 & 0 & 5.530346 & 0 & 5.36967 & 0 & 5.512118 & 0 \\
\hline Th & 0.35781 & 0.99756 & 1.039935 & 1.460951 & 0.829188 & 0.162514 & 0.581997 & 7.10656 & 0.260142 \\
\hline $\mathrm{U}$ & 0.182916 & 0.23347 & 0.272818 & 0.424924 & 0.20451 & 0 & 0.148802 & 0.696309 & 0.078576 \\
\hline$d$ & 2.867294 & 3.043556 & 3.042189 & 2.841331 & 2.941789 & 3.042672 & 3.062258 & 2.744098 & 3.026511 \\
\hline
\end{tabular}


Anexo B - continuação.

\begin{tabular}{|c|c|c|c|c|c|c|c|c|c|}
\hline SAMPLE & IP136 & IP210B & IP474 & IP532 & IP606 & IP609 & IP617A & IP637A & IP638B \\
\hline $\mathrm{SiO} 2$ & 63.8 & 49.36 & 49.94 & 44.83 & 49.46 & 47.38 & 61.25 & 47.29 & 45.61 \\
\hline Al2O3 & 12.26 & 18.56 & 13.67 & 12.36 & 14.22 & 12.92 & 12.48 & 14.45 & 14.37 \\
\hline $\mathrm{Fe} 2 \mathrm{O} 3$ & 7.35 & 6.99 & 14.42 & 12.7 & 11.53 & 15.45 & 15.42 & 9.13 & 9.16 \\
\hline $\mathrm{MnO}$ & 0.523 & 0.148 & 0.198 & 0.238 & 0.158 & 0.15 & 0.103 & 0.162 & 0.151 \\
\hline $\mathrm{MgO}$ & 4.35 & 8.05 & 6.08 & 6.04 & 7.28 & 4.83 & 1.36 & 10.94 & 10.98 \\
\hline $\mathrm{CaO}$ & 5.51 & 10.29 & 9 & 9.61 & 11.93 & 5.57 & 1.96 & 15.02 & 16.67 \\
\hline $\mathrm{Na2O}$ & 0.87 & 2.37 & 3.02 & 2.15 & 2.25 & 3.2 & 3.09 & 1.04 & 0.68 \\
\hline $\mathrm{K} 2 \mathrm{O}$ & 3.58 & 1.36 & 0.27 & 0.04 & 0.18 & 0 & 0.36 & 0.03 & 0.05 \\
\hline TiO2 & 0.557 & 0.33 & 2.299 & 1.084 & 1.446 & 1.436 & 1.004 & 0.438 & 0.414 \\
\hline $\mathrm{P} 2 \mathrm{O5}$ & 0.12 & 0.05 & 0.2 & 0.11 & 0.15 & 0.13 & 0.31 & 0.03 & 0.03 \\
\hline $\mathrm{LOI}$ & 1.88 & 3.12 & 0.58 & 11.57 & 1.5 & 7.79 & 1.42 & 2.44 & 2.13 \\
\hline TOTAL & 100.82 & 100.63 & 99.68 & 100.71 & 100.11 & 98.85 & 98.75 & 100.97 & 100.24 \\
\hline Sc & 12 & 39 & 36 & 43 & 36 & 43 & 25 & 46 & 45 \\
\hline $\mathrm{V}$ & 75.92282 & 165.6495 & 405.9772 & 320.7767 & 303.3916 & 396.9761 & 19.66725 & 213.2392 & 196.8342 \\
\hline $\mathrm{Cr}$ & 85.34048 & 287.2575 & 108.9951 & 63.00252 & 120.9456 & 46.91201 & 26.47389 & 633.3733 & 691.1135 \\
\hline Co & 15.08198 & 28.07719 & 40.10677 & 39.43126 & 35.15648 & 43.38302 & 8.496517 & 36.78018 & 35.15506 \\
\hline $\mathrm{Ni}$ & 169.7104 & 92.42429 & 110.292 & 70.1479 & 123.9927 & 60.55951 & 26.64905 & 207.9835 & 200.0814 \\
\hline $\mathrm{Cu}$ & 13.15782 & 39.81363 & 142.4419 & 144.8096 & 84.07559 & 88.60741 & 14.98657 & 58.48219 & 87.6445 \\
\hline $\mathrm{Zn}$ & 298.2801 & 32.98349 & 113.2669 & 83.23368 & 63.23104 & 56.00765 & 116.5967 & 61.52263 & 37.12415 \\
\hline $\mathrm{Ga}$ & 19.11429 & 13.29444 & 21.51072 & 14.74573 & 18.14965 & 17.67501 & 21.50464 & 13.9686 & 13.01058 \\
\hline As & 6.175909 & 6.273743 & 26.75497 & 6.455701 & 0 & 0 & 0 & 11.47881 & 10.94416 \\
\hline $\mathrm{Rb}$ & 229.6414 & 59.28842 & 5.410114 & 4.429959 & 3.803379 & 0 & 21.88447 & 0 & 0 \\
\hline $\mathrm{Sr}$ & 202.0624 & 138.543 & 302.5694 & 237.9551 & 487.9688 & 60.09164 & 132.7907 & 147.6451 & 151.4896 \\
\hline $\mathrm{Y}$ & 31.14638 & 8.823099 & 30.39404 & 22.48617 & 19.95983 & 31.04494 & 38.3861 & 8.822601 & 8.406747 \\
\hline Zr & 141.58 & 19.09183 & 167.4577 & 65.77414 & 97.56997 & 85.26931 & 343.8079 & 23.24141 & 21.13931 \\
\hline $\mathrm{Nb}$ & 11.31313 & 0.857944 & 14.78275 & 3.093256 & 9.194049 & 3.547749 & 12.08763 & 1.111793 & 1.124659 \\
\hline Cs & 28.47713 & 2.078098 & 0.521202 & 2.505885 & 0.245535 & 0 & 4.015199 & 0.125763 & 0.196081 \\
\hline $\mathrm{Ba}$ & 752.656 & 325.8679 & 99.82868 & 138.54 & 29.33416 & 8.325588 & 86.46453 & 11.14294 & 39.05167 \\
\hline $\mathrm{La}$ & 29.48354 & 1.379179 & 19.3166 & 2.786806 & 10.67314 & 3.832088 & 17.05955 & 1.704674 & 1.71107 \\
\hline $\mathrm{Ce}$ & 59.83305 & 3.203338 & 35.41078 & 7.709008 & 20.67559 & 10.52803 & 46.64834 & 3.419927 & 3.185274 \\
\hline $\mathrm{Pr}$ & 6.436563 & 0.45133 & 5.780737 & 1.202402 & 3.188513 & 1.621978 & 6.907354 & 0.555123 & 0.573439 \\
\hline $\mathrm{Nd}$ & 25.20424 & 2.326175 & 26.86076 & 6.465945 & 15.11896 & 8.869004 & 34.45197 & 3.128878 & 2.959234 \\
\hline Sm & 4.785598 & 0.772757 & 6.260996 & 2.096131 & 3.737435 & 3.009745 & 9.329637 & 1.051532 & 0.997139 \\
\hline$\overline{\mathrm{Eu}}$ & 0.936959 & 0.359235 & 2.126642 & 0.84589 & 1.425864 & 1.172982 & 2.789564 & 0.505862 & 0.495704 \\
\hline Gd & 4.268239 & 1.117578 & 6.201237 & 2.708477 & 3.800809 & 3.70589 & 8.41553 & 1.409646 & 1.346419 \\
\hline $\mathrm{Tb}$ & 0.801815 & 0.219563 & 1.034499 & 0.564713 & 0.635001 & 0.766445 & 1.34901 & 0.254271 & 0.235809 \\
\hline Dy & 4.928062 & 1.507301 & 5.94356 & 3.822901 & 3.783678 & 5.225147 & 7.626295 & 1.610544 & 1.506312 \\
\hline $\mathrm{Ho}$ & 0.978909 & 0.319027 & 1.075934 & 0.772972 & 0.708064 & 1.102561 & 1.510684 & 0.316727 & 0.293487 \\
\hline $\mathrm{Er}$ & 2.871486 & 0.985699 & 3.084057 & 2.421795 & 2.000335 & 3.369982 & 4.712312 & 0.8898 & 0.871549 \\
\hline $\mathrm{Tm}$ & 0.439927 & 0.15061 & 0.435244 & 0.364838 & 0.278178 & 0.525326 & 0.763681 & 0.134132 & 0.123398 \\
\hline $\mathrm{Yb}$ & 2.704728 & 0.996777 & 2.701043 & 2.306718 & 1.762541 & 3.449234 & 5.102128 & 0.836185 & 0.770572 \\
\hline$\overline{\mathrm{Lu}}$ & 0.384744 & 0.14272 & 0.372494 & 0.356949 & 0.241482 & 0.511154 & 0.791696 & 0.113533 & 0.110393 \\
\hline $\mathrm{Hf}$ & 3.713635 & 0.554688 & 4.203245 & 1.716946 & 2.503849 & 2.343 & 8.900404 & 0.626849 & 0.582792 \\
\hline $\mathrm{Ta}$ & 0.972714 & 0 & 1.262878 & 0.1765 & 0.657261 & 0.201656 & 0.87908 & 0 & 0 \\
\hline $\mathrm{Pb}$ & 7.994989 & 0 & 8.482057 & 0 & 0 & 0 & 5.919368 & 0 & 0 \\
\hline Th & 9.4808 & 0.212752 & 1.823757 & 0.293731 & 0.914091 & 0.379712 & 2.676199 & 0.095872 & 0.088311 \\
\hline $\mathrm{U}$ & 1.523839 & 0 & 0.435801 & 0.096516 & 0.236232 & 0.129766 & 0.70071 & 0 & 0 \\
\hline$d$ & 2.849603 & 3.023483 & 3.050857 & 2.780299 & 3.080529 & 2.784021 & 2.803542 & 3.119737 & 3.189141 \\
\hline
\end{tabular}


ANEXO C

Planilhas de cálculo de variação volumétrica 


\section{Anexo C}

Tabela C1

\begin{tabular}{|c|c|c|c|c|c|c|c|c|}
\hline & Final & Inicial & & & Perdas - ganh & hos abs. & Relativos (/m & \\
\hline SAMPLE & GD487 & GD486A & Final//nicial & Fv para $x=0$ & Ti imóvel & Zr imóvel & Ti imóvel & Zr imóvel \\
\hline $\mathrm{SiO} 2$ & 42.72 & 49.21 & 0.868116 & 1.233350538 & -14.4821 & -14.9889 & -0.29429 & -0.30459 \\
\hline $\mathrm{Al} 2 \mathrm{O} 3$ & 11.93 & 14.38 & 0.829624 & 1.290573814 & -4.68187 & -4.8234 & -0.32558 & -0.33542 \\
\hline $\mathrm{Fe} 2 \mathrm{O} 3$ & 12.90 & 11.34 & 1.137566 & 0.94121264 & -0.85333 & -1.00638 & -0.07525 & -0.08875 \\
\hline $\mathrm{MnO}$ & 0.194 & 0.166 & 1.168675 & 0.916158815 & -0.00829 & -0.0106 & -0.04996 & -0.06383 \\
\hline $\mathrm{MgO}$ & 5.60 & 7.32 & 0.765027 & 1.399546913 & -2.76765 & -2.83409 & -0.37809 & -0.38717 \\
\hline $\mathrm{CaO}$ & 9.36 & 11.94 & 0.78392 & 1.365818166 & -4.33107 & -4.44212 & -0.36274 & -0.37204 \\
\hline $\mathrm{Na} 2 \mathrm{O}$ & 2.49 & 2.12 & 1.174528 & 0.911592871 & -0.09583 & -0.12537 & -0.0452 & -0.05914 \\
\hline $\mathrm{K} 2 \mathrm{O}$ & 0.05 & 0.21 & 0.238095 & 4.496904835 & -0.16935 & -0.16995 & -0.80645 & -0.80927 \\
\hline $\mathrm{TiO} 2$ & 1.935 & 1.573 & 1.230134 & 0.870386527 & 0 & -0.02296 & 0 & -0.01459 \\
\hline P2O5 & 0.16 & 0.16 & 1 & 1.070691627 & -0.02993 & -0.03183 & -0.18708 & -0.19894 \\
\hline LOI & 11.47 & 1.70 & 6.747059 & 0.158690128 & 7.624191 & 7.488112 & 4.484818 & 4.404772 \\
\hline TOTAL & 98.80 & 100.11 & 0.986914 & 1.084888045 & -19.7935 & -20.9657 & -0.19772 & -0.20943 \\
\hline Sc & 32 & 36 & 0.888889 & 1.204528081 & -9.98656 & -10.3662 & -0.2774 & -0.28795 \\
\hline $\mathrm{V}$ & 355 & 314 & 1.131339 & 0.946393442 & -25.183 & -29.3917 & -0.08031 & -0.09373 \\
\hline $\mathrm{Cr}$ & 73 & 237 & 0.307327 & 3.483881353 & -178.004 & -178.87 & -0.75017 & -0.75381 \\
\hline Co & 37 & 34 & 1.090836 & 0.981532922 & -3.88887 & -4.33332 & -0.11324 & -0.12618 \\
\hline $\mathrm{Ni}$ & 92 & 126 & 0.72925 & 1.468209766 & -51.2374 & -52.3261 & -0.40718 & -0.41583 \\
\hline $\mathrm{Cu}$ & 91 & 109 & 0.835381 & 1.281681161 & -35.0982 & -36.1822 & -0.3209 & -0.33081 \\
\hline$Z n$ & 98 & 39 & 2.538173 & 0.421835528 & 41.00167 & 39.84053 & 1.063331 & 1.033219 \\
\hline $\mathrm{Ga}$ & 19 & 18 & 1.047956 & 1.021695416 & -2.66743 & -2.89136 & -0.1481 & -0.16053 \\
\hline As & 0 & 12 & 0 & \#DIV/0! & -12.3435 & -12.3435 & -1 & -1 \\
\hline $\mathrm{Rb}$ & 3 & 6 & 0.50525 & 2.11913298 & -3.25377 & -3.28687 & -0.58927 & -0.59527 \\
\hline $\mathrm{Sr}$ & 422 & 402 & 1.049148 & 1.020534216 & -59.1983 & -64.2065 & -0.14713 & -0.15957 \\
\hline $\mathrm{Y}$ & 21.7 & 19.8 & 1.096609 & 0.976366171 & -2.14705 & -2.40439 & -0.10854 & -0.12156 \\
\hline$Z r$ & 131 & 105 & 1.248352 & 0.857683899 & 1.550347 & 0 & 0.01481 & 0 \\
\hline $\mathrm{Nb}$ & 14.2 & 10.0 & 1.41994 & 0.754040056 & 1.539029 & 1.370999 & 0.154297 & 0.137451 \\
\hline Cs & 1.2 & 0.3 & 4.213174 & 0.25412946 & 0.674002 & 0.660109 & 2.424973 & 2.374988 \\
\hline $\mathrm{Ba}$ & 56 & 54 & 1.036808 & 1.032680605 & -8.49202 & -9.15668 & -0.15716 & -0.16946 \\
\hline $\mathrm{La}$ & 13.7 & 10.2 & 1.347169 & 0.794771682 & 0.967541 & 0.805003 & 0.09514 & 0.079158 \\
\hline $\mathrm{Ce}$ & 31.7 & 23.6 & 1.34479 & 0.796177736 & 2.198401 & 1.822092 & 0.093206 & 0.077252 \\
\hline $\mathrm{Pr}$ & 4.17 & 3.11 & 1.338224 & 0.800083908 & 0.273551 & 0.224124 & 0.087869 & 0.071992 \\
\hline $\mathrm{Nd}$ & 19.1 & 14.6 & 1.305972 & 0.819842845 & 0.901645 & 0.675044 & 0.06165 & 0.046156 \\
\hline Sm & 4.58 & 3.74 & 1.224177 & 0.874621537 & -0.01811 & -0.07242 & -0.00484 & -0.01937 \\
\hline $\mathrm{Eu}$ & 1.71 & 1.40 & 1.223128 & 0.875371801 & -0.00795 & -0.02822 & -0.0057 & -0.02021 \\
\hline $\mathrm{Gd}$ & 4.52 & 3.69 & 1.224008 & 0.874742361 & -0.01839 & -0.07201 & -0.00498 & -0.0195 \\
\hline $\mathrm{Tb}$ & 0.78 & 0.64 & 1.217195 & 0.87963834 & -0.00671 & -0.01593 & -0.01052 & -0.02496 \\
\hline Dy & 4.51 & 3.77 & 1.194995 & 0.895979825 & -0.10783 & -0.16135 & -0.02856 & -0.04274 \\
\hline $\mathrm{Ho}$ & 0.85 & 0.71 & 1.198091 & 0.893664462 & -0.01848 & -0.02857 & -0.02605 & -0.04026 \\
\hline $\mathrm{Er}$ & 2.36 & 2.04 & 1.157839 & 0.92473245 & -0.11987 & -0.14789 & -0.05877 & -0.07251 \\
\hline $\mathrm{Tm}$ & 0.333 & 0.288 & 1.156488 & 0.925813176 & -0.01722 & -0.02117 & -0.05987 & -0.07359 \\
\hline $\mathrm{Yb}$ & 2.03 & 1.80 & 1.128358 & 0.948893776 & -0.14915 & -0.17328 & -0.08274 & -0.09612 \\
\hline $\mathrm{Lu}$ & 0.302 & 0.255 & 1.184771 & 0.903711901 & -0.0094 & -0.01299 & -0.03688 & -0.05093 \\
\hline $\mathrm{Hf}$ & 3.5 & 2.7 & 1.302318 & 0.822143224 & 0.157511 & 0.116038 & 0.05868 & 0.043229 \\
\hline $\mathrm{Ta}$ & 1.1 & 0.7 & 1.54959 & 0.690951619 & 0.184702 & 0.171627 & 0.259692 & 0.241308 \\
\hline $\mathrm{Pb}$ & 6 & 0 & \#DIV/0! & 0 & 4.495728 & 4.430117 & \#DIV/0! & \#DIV/0! \\
\hline Th & 1.46 & 1.04 & 1.404848 & 0.762140344 & 0.147701 & 0.130368 & 0.142029 & 0.125362 \\
\hline $\mathrm{U}$ & 0.42 & 0.27 & 1.557537 & 0.687426336 & 0.072611 & 0.06757 & 0.266152 & 0.247674 \\
\hline \multirow[t]{2}{*}{$\mathrm{d}$} & 2.84 & 3.04 & 0.933976 & & & & & \\
\hline & & & $\mathrm{FV}=$ & & 0.870387 & 0.857684 & & \\
\hline
\end{tabular}


Tabela C2

\begin{tabular}{|c|c|c|c|c|c|c|c|c|}
\hline & Final & Inicial & & & Perdas - ganh & hos abs. & Relativos $(/ \mathrm{mc}$ & \\
\hline SAMPLE & IP609 & $\begin{array}{l}\text { Média } \\
\text { família } 2 \text { ) }\end{array}$ & Final/Inicial & $F v$ para $x=0$ & Ti imóvel & Zr imóvel & Ti imóvel & Zr imóvel \\
\hline $\mathrm{SiO} 2$ & 47.38 & 45.67 & 1.03754 & 0.868468304 & -4.20586 & -5.23581 & -0.0921 & -0.11466 \\
\hline $\mathrm{Al} 2 \mathrm{O} 3$ & 12.92 & 13.87 & 0.931699 & 0.967126426 & -2.5615 & -2.84236 & -0.18472 & -0.20497 \\
\hline Fe2O3 & 15.45 & 13.39 & 1.153723 & 0.781011088 & 0.12809 & -0.20776 & 0.009565 & -0.01551 \\
\hline $\mathrm{MnO}$ & 0.150 & 0.218 & 0.688976 & 1.307839477 & -0.08646 & -0.08972 & -0.39711 & -0.41209 \\
\hline $\mathrm{MgO}$ & 4.83 & 7.07 & 0.683168 & 1.318958276 & -2.84351 & -2.9485 & -0.40219 & -0.41704 \\
\hline $\mathrm{CaO}$ & 5.57 & 9.85 & 0.5654 & 1.593686126 & -4.9774 & -5.09848 & -0.50525 & -0.51754 \\
\hline $\mathrm{Na2O}$ & 3.20 & 2.30 & 1.390441 & 0.648046689 & 0.498731 & 0.429169 & 0.216705 & 0.186479 \\
\hline $\mathrm{K} 2 \mathrm{O}$ & 0.00 & 0.34 & 0 & \#DIV/0! & -0.33714 & -0.33714 & -1 & -1 \\
\hline TiO2 & 1.436 & 1.257 & 1.142792 & 0.788481513 & 0 & -0.03122 & 0 & -0.02484 \\
\hline P2O5 & 0.13 & 0.14 & 0.947917 & 0.950579874 & -0.02339 & -0.02621 & -0.17053 & -0.19113 \\
\hline LOI & 7.79 & 5.25 & 1.485022 & 0.606772583 & 1.570923 & 1.401583 & 0.299468 & 0.267186 \\
\hline TOTAL & 98.85 & 99.33 & 0.995125 & 0.905485028 & -12.8356 & -14.9844 & -0.12922 & -0.15085 \\
\hline Sc & 43 & 36.57143 & 1.175781 & 0.766358968 & 1.05571 & 0.120971 & 0.028867 & 0.003308 \\
\hline $\mathrm{V}$ & 397 & 288 & 1.376951 & 0.654395569 & 59.07298 & 50.44346 & 0.2049 & 0.174968 \\
\hline $\mathrm{Cr}$ & 47 & 101 & 0.464334 & 1.940566025 & -59.9804 & -61.0002 & -0.59368 & -0.60378 \\
\hline Co & 43 & 31 & 1.405219 & 0.641231336 & 7.089521 & 6.146455 & 0.229637 & 0.19909 \\
\hline $\mathrm{Ni}$ & 61 & 79 & 0.76203 & 1.182461198 & -26.4787 & -27.7952 & -0.33319 & -0.34975 \\
\hline $\mathrm{Cu}$ & 89 & 88 & 1.008044 & 0.893879704 & -10.3644 & -12.2906 & -0.11791 & -0.13982 \\
\hline $\mathrm{Zn}$ & 56 & 62 & 0.901152 & 0.999909665 & -13.1417 & -14.3592 & -0.21145 & -0.23104 \\
\hline $\mathrm{Ga}$ & 18 & 16 & 1.128691 & 0.798332662 & -0.19324 & -0.57746 & -0.01234 & -0.03688 \\
\hline As & 0 & 7 & 0 & \#DIV/0! & -7.33646 & -7.33646 & -1 & -1 \\
\hline $\mathrm{Rb}$ & 0 & 8 & 0 & \#DIV/0! & -8.46886 & -8.46886 & -1 & -1 \\
\hline $\mathrm{Sr}$ & 60 & 192 & 0.312512 & 2.883317139 & \begin{tabular}{|l|}
-139.703 \\
\end{tabular} & -141.009 & -0.72654 & -0.73333 \\
\hline $\mathrm{Y}$ & 31.0 & 20.4 & 1.52202 & 0.592022844 & 6.768669 & 6.09381 & 0.331843 & 0.298757 \\
\hline $\mathrm{Zr}$ & 85 & 73 & 1.171905 & 0.768893924 & 1.853595 & 0 & 0.025475 & 0 \\
\hline $\mathrm{Nb}$ & 3.5 & 4.6 & 0.775909 & 1.161309886 & -1.46792 & -1.54504 & -0.32104 & -0.33791 \\
\hline Cs & 0.0 & 0.9 & 0 & \#DIV/0! & -0.88231 & -0.88231 & -1 & -1 \\
\hline $\mathrm{Ba}$ & 8 & 57 & 0.145962 & 6.17330349 & -49.7539 & -49.9349 & -0.87228 & -0.87545 \\
\hline $\mathrm{La}$ & 3.8 & 4.4 & 0.878029 & 1.026242092 & -1.01115 & -1.09445 & -0.23168 & -0.25077 \\
\hline $\mathrm{Ce}$ & 10.5 & 10.2 & 1.029157 & 0.875542386 & -1.01721 & -1.24607 & -0.09944 & -0.12181 \\
\hline $\mathrm{Pr}$ & 1.62 & 1.58 & 1.023386 & 0.880479726 & -0.1656 & -0.20086 & -0.10449 & -0.12673 \\
\hline $\mathrm{Nd}$ & 8.9 & 8.0 & 1.111552 & 0.81064146 & -0.21811 & -0.41091 & -0.02734 & -0.0515 \\
\hline $\mathrm{Sm}$ & 3.01 & 2.44 & 1.233214 & 0.730668512 & 0.193106 & 0.12768 & 0.079123 & 0.052316 \\
\hline $\mathrm{Eu}$ & 1.17 & 0.98 & 1.199049 & 0.751487543 & 0.048157 & 0.022659 & 0.049228 & 0.023163 \\
\hline $\mathrm{Gd}$ & 3.71 & 2.88 & 1.284616 & 0.701431649 & 0.358016 & 0.277456 & 0.124103 & 0.096178 \\
\hline $\mathrm{Tb}$ & 0.77 & 0.56 & 1.364399 & 0.660415801 & 0.108932 & 0.092271 & 0.193917 & 0.164257 \\
\hline Dy & 5.23 & 3.62 & 1.445219 & 0.623483806 & 0.956792 & 0.843207 & 0.264638 & 0.233222 \\
\hline $\mathrm{Ho}$ & 1.10 & 0.72 & 1.526891 & 0.590134262 & 0.2427 & 0.218733 & 0.336105 & 0.302914 \\
\hline $\mathrm{Er}$ & 3.37 & 2.16 & 1.558841 & 0.578038628 & 0.787051 & 0.713794 & 0.364064 & 0.330177 \\
\hline $\mathrm{Tm}$ & 0.525 & 0.319 & 1.644769 & 0.547840226 & 0.140294 & 0.128875 & 0.439255 & 0.4035 \\
\hline $\mathrm{Yb}$ & 3.45 & 1.99 & 1.734383 & 0.519533881 & 1.029512 & 0.954533 & 0.517671 & 0.479969 \\
\hline Lu & 0.511 & 0.288 & 1.77354 & 0.508063245 & 0.159074 & 0.147963 & 0.551936 & 0.513382 \\
\hline $\mathrm{Hff}$ & 2.3 & 1.9 & 1.229755 & 0.732723823 & 0.144983 & 0.094051 & 0.076096 & 0.049364 \\
\hline $\mathrm{Ta}$ & 0.2 & 0.3 & 0.636278 & 1.416158161 & -0.14047 & -0.14486 & -0.44322 & -0.45706 \\
\hline $\mathrm{Pb}$ & 0 & 2 & 0 & \#DIV/0! & -2.09866 & -2.09866 & -1 & -1 \\
\hline $\mathrm{Th}$ & 0.38 & 0.58 & 0.657199 & 1.371077202 & -0.24551 & -0.25376 & -0.42492 & -0.4392 \\
\hline $\mathrm{U}$ & 0.13 & 0.15 & 0.868613 & 1.037366593 & -0.03584 & -0.03866 & -0.23992 & -0.2588 \\
\hline \multirow[t]{2}{*}{$\mathrm{d}$} & 2.78 & 2.51 & 1.109791 & & & & & \\
\hline & & & $\mathrm{FV}=$ & & 0.788482 & 0.768894 & & \\
\hline
\end{tabular}


Tabela C3

\begin{tabular}{|c|c|c|c|c|c|c|c|c|}
\hline & Final & Inicial & & & Perdas - ganl & hos abs. & Relativos (/m & \\
\hline SAMPLE & IP532 & GD541 & Final/Inicial & $F v$ para $x=0$ & Ti imóvel & Zr imóvel & Ti imóvel & Zr imóvel \\
\hline SiO2 & 44.83 & 49.08 & 0.913407 & 1.205829901 & 1.705277 & -5.42831 & 0.034745 & -0.1106 \\
\hline Al2O3 & 12.36 & 13.76 & 0.898256 & 1.226168618 & 0.241919 & -1.72487 & 0.017581 & -0.12535 \\
\hline $\mathrm{Fe} 2 \mathrm{O} 3$ & 12.70 & 12.42 & 1.022544 & 1.077129966 & 1.967085 & -0.05381 & 0.15838 & -0.00433 \\
\hline $\mathrm{MnO}$ & 0.238 & 0.190 & 1.252632 & 0.879279357 & 0.079616 & 0.041744 & 0.419033 & 0.219707 \\
\hline $\mathrm{MgO}$ & 6.04 & 6.39 & 0.945227 & 1.165236696 & 0.452362 & -0.50876 & 0.070792 & -0.07962 \\
\hline $\mathrm{CaO}$ & 9.61 & 11.42 & 0.841506 & 1.30885926 & -0.53339 & -2.06259 & -0.04671 & -0.18061 \\
\hline $\mathrm{Na2O}$ & 2.15 & 1.76 & 1.221591 & 0.901621878 & 0.675609 & 0.333489 & 0.383869 & 0.189483 \\
\hline $\mathrm{K} 2 \mathrm{O}$ & 0.04 & 0.17 & 0.235294 & 4.681005631 & -0.12469 & -0.13105 & -0.73345 & -0.77089 \\
\hline TiO2 & 1.084 & 1.228 & 0.882736 & 1.247726268 & 0 & -0.17249 & 0 & -0.14047 \\
\hline P2O5 & 0.11 & 0.10 & 1.1 & 1.001284627 & 0.024613 & 0.007109 & 0.246125 & 0.071088 \\
\hline LOI & 11.57 & 2.15 & 5.381395 & 0.20467054 & 10.95697 & 9.115895 & 5.096267 & 4.239951 \\
\hline TOTAL & 100.71 & 98.67 & 1.020675 & 1.079102667 & 15.41845 & -0.60706 & 0.156263 & -0.00615 \\
\hline Sc & 43 & 42 & 1.02381 & 1.075798832 & 6.712177 & -0.13021 & 0.159814 & -0.0031 \\
\hline $\mathrm{V}$ & 321 & 320 & 1.002855 & 1.098277353 & 43.52565 & -7.51803 & 0.136076 & -0.0235 \\
\hline $\mathrm{Cr}$ & 63 & 92 & 0.687736 & 1.60150671 & -20.2368 & -30.2621 & -0.2209 & -0.33034 \\
\hline Co & 39 & 33 & 1.178721 & 0.934413817 & 11.21678 & 4.942265 & 0.335304 & 0.147739 \\
\hline $\mathrm{Ni}$ & 70 & 70 & 1.004366 & 1.09662523 & 9.623474 & -1.53883 & 0.137787 & -0.02203 \\
\hline $\mathrm{Cu}$ & 145 & 34 & 4.263441 & 0.258338994 & 130.0809 & 107.038 & 3.829802 & 3.151381 \\
\hline $\mathrm{Zn}$ & 83 & 0 & \#DIV/0! & 0 & 94.29055 & 81.04597 & \#DIV/0! & \#DIV/0! \\
\hline $\mathrm{Ga}$ & 15 & 16 & 0.898895 & 1.225296711 & 0.300287 & -2.04613 & 0.018305 & -0.12473 \\
\hline As & 6 & 0 & \#DIV/0! & 0 & 7.313285 & 6.28602 & \#DIV/0! & \#DIV/0! \\
\hline $\mathrm{Rb}$ & 4 & 5 & 0.893222 & 1.233078671 & 0.058914 & -0.646 & 0.011879 & -0.13026 \\
\hline $\mathrm{Sr}$ & 238 & 160 & 1.487237 & 0.740576753 & 109.5673 & 71.7026 & 0.684803 & 0.448146 \\
\hline $\mathrm{Y}$ & 22.5 & 24.9 & 0.904872 & 1.217203 & 0.623155 & -2.95496 & 0.025077 & -0.11891 \\
\hline $\mathrm{Zr}$ & 66 & 64 & 1.026993 & 1.072463588 & 10.46633 & 0 & 0.163421 & 0 \\
\hline $\mathrm{Nb}$ & 3.1 & 5.0 & 0.616127 & 1.787640272 & -1.51632 & -2.00853 & -0.30203 & -0.40007 \\
\hline Cs & 2.5 & 0.1 & 19.60173 & 0.056189589 & 2.71093 & 2.31218 & 21.20565 & 18.08652 \\
\hline $\mathrm{Ba}$ & 139 & 53 & 2.595687 & 0.424324312 & 103.5707 & 81.52545 & 1.940501 & 1.527462 \\
\hline $\mathrm{La}$ & 2.8 & 6.4 & 0.43668 & 2.522244773 & -3.2248 & -3.66825 & -0.50531 & -0.5748 \\
\hline $\mathrm{Ce}$ & 7.7 & 15.6 & 0.495064 & 2.22479084 & -6.83867 & -8.06537 & -0.43917 & -0.51795 \\
\hline $\operatorname{Pr}$ & 1.20 & 2.03 & 0.592461 & 1.859047366 & -0.66737 & -0.85871 & -0.32884 & -0.42311 \\
\hline $\mathrm{Nd}$ & 6.5 & 9.8 & 0.661511 & 1.664996108 & -2.44962 & -3.47852 & -0.25061 & -0.35588 \\
\hline $\mathrm{Sm}$ & 2.10 & 2.87 & 0.73105 & 1.506617924 & -0.4927 & -0.82625 & -0.17184 & -0.28816 \\
\hline $\mathrm{Eu}$ & 0.85 & 1.17 & 0.723392 & 1.522566976 & -0.21108 & -0.34568 & -0.18051 & -0.29562 \\
\hline $\mathrm{Gd}$ & 2.71 & 3.36 & 0.806351 & 1.365923237 & -0.29066 & -0.72164 & -0.08653 & -0.21484 \\
\hline $\mathrm{Tb}$ & 0.56 & 0.64 & 0.878565 & 1.253650767 & -0.00304 & -0.0929 & -0.00473 & -0.14453 \\
\hline Dy & 3.82 & 4.17 & 0.915789 & 1.202692994 & 0.156306 & -0.45201 & 0.037444 & -0.10828 \\
\hline $\mathrm{Ho}$ & 0.77 & 0.85 & 0.909758 & 1.210666397 & 0.026009 & -0.09699 & 0.030611 & -0.11415 \\
\hline $\mathrm{Er}$ & 2.42 & 2.57 & 0.942666 & 1.168402817 & 0.174417 & -0.21095 & 0.06789 & -0.08211 \\
\hline $\mathrm{Tm}$ & 0.365 & 0.379 & 0.962523 & 1.144298035 & 0.03426 & -0.02379 & 0.090386 & -0.06278 \\
\hline $\mathrm{Yb}$ & 2.31 & 2.33 & 0.988017 & 1.114771564 & 0.27845 & -0.08861 & 0.119266 & -0.03795 \\
\hline $\mathrm{Lu}$ & 0.357 & 0.342 & 1.043952 & 1.055042219 & 0.062446 & 0.005646 & 0.182632 & 0.016512 \\
\hline $\mathrm{Hf}$ & 1.7 & 1.8 & 0.940517 & 1.171072442 & 0.119492 & -0.15372 & 0.065456 & -0.0842 \\
\hline $\mathrm{Ta}$ & 0.2 & 0.3 & 0.664753 & 1.656874744 & -0.06557 & -0.09365 & -0.24694 & -0.35272 \\
\hline $\mathrm{Pb}$ & 0 & 0 & \#DIV/0! & \#DIV/0! & 0 & 0 & \#DIV/0! & \#DIV/0! \\
\hline $\mathrm{Th}$ & 0.29 & 0.58 & 0.504695 & 2.182333884 & -0.24925 & -0.29599 & -0.42826 & -0.50857 \\
\hline $\mathrm{U}$ & 0.10 & 0.15 & 0.64862 & 1.698086023 & -0.03946 & -0.05482 & -0.26522 & -0.36843 \\
\hline \multirow[t]{2}{*}{$\mathrm{d}$} & 2.78 & 3.06 & 0.907925 & & & & & \\
\hline & & & $F V=$ & & 1.247726 & 1.072464 & & \\
\hline
\end{tabular}


Tabela C4

\begin{tabular}{|c|c|c|c|c|c|c|c|c|}
\hline & Final & Inicial & & & Perdas - ganh & רos abs. & Relativos $(/ \mathrm{mC}$ & \\
\hline SAMPLE & $\begin{array}{l}\text { Média } \\
\text { GD109 e } \\
\text { GD177 }\end{array}$ & \begin{tabular}{|l} 
Média \\
demais \\
família 3
\end{tabular} & Final/Inicial & $F \vee$ para $x=0$ & Ti imóvel & Y imóvel & Ti imóvel & Y imóvel \\
\hline $\mathrm{SiO} 2$ & 48.82 & 47.53 & 1.027227 & 1.010071485 & -22.6526 & -9.37036 & -0.47664 & -0.19716 \\
\hline $\mathrm{Al} 2 \mathrm{O} 3$ & 13.81 & 15.40 & 0.896312 & 1.157602166 & -8.36848 & -4.6126 & -0.54334 & -0.29948 \\
\hline Fe2O3 & 11.41 & 8.49 & 1.342713 & 0.772743907 & -2.68325 & 0.419663 & -0.3159 & 0.049407 \\
\hline $\mathrm{MnO}$ & 0.166 & 0.159 & 1.038269 & 0.999330037 & -0.07508 & -0.03005 & -0.47101 & -0.18853 \\
\hline $\mathrm{MgO}$ & 10.20 & 10.02 & 1.018371 & 1.018855904 & -4.81919 & -2.04411 & -0.48115 & -0.20408 \\
\hline $\mathrm{CaO}$ & 10.11 & 14.25 & 0.709673 & 1.462043879 & -9.09505 & -6.34445 & -0.63843 & -0.44535 \\
\hline $\mathrm{Na2O}$ & 2.12 & 1.15 & 1.837088 & 0.564792044 & -0.07388 & 0.502902 & -0.06402 & 0.43579 \\
\hline K2O & 0.18 & 0.43 & 0.416667 & 2.490174974 & -0.34029 & -0.29132 & -0.78771 & -0.67435 \\
\hline \begin{tabular}{l|l}
$\mathrm{TiO} 2$ \\
\end{tabular} & 0.727 & 0.370 & 1.962743 & 0.528634119 & 0 & 0.197792 & 0 & 0.533996 \\
\hline P2O5 & 0.05 & 0.03 & 1.470588 & 0.705549576 & -0.00853 & 0.005078 & -0.25075 & 0.149349 \\
\hline LOI & 2.11 & 2.44 & 0.861293 & 1.20466897 & -1.37152 & -0.79882 & -0.56118 & -0.32685 \\
\hline TOTAL & 99.70 & 100.27 & 0.994315 & 1.043504867 & -49.4737 & -22.3487 & -0.49341 & -0.22289 \\
\hline $\mathrm{Sc}$ & 41 & 45.6 & 0.899123 & 1.153983524 & -24.7109 & -13.5561 & -0.5419 & -0.29728 \\
\hline $\mathrm{V}$ & 231 & 193 & 1.198728 & 0.865561545 & -75.0343 & -12.1681 & -0.38926 & -0.06313 \\
\hline $\mathrm{Cr}$ & 445 & 390 & 1.142052 & 0.908516062 & -162.997 & -41.8746 & -0.41813 & -0.10742 \\
\hline Co & 50 & 35 & 1.442223 & 0.719425998 & -9.25784 & 4.439726 & -0.2652 & 0.12718 \\
\hline $\mathrm{Ni}$ & 196 & 149 & 1.313042 & 0.790205315 & -49.2991 & 3.904702 & -0.33102 & 0.026218 \\
\hline $\mathrm{Cu}$ & 79 & 52 & 1.542093 & 0.672834292 & -11.0417 & 10.57372 & -0.21432 & 0.205234 \\
\hline $\mathrm{Zn}$ & 55 & 48 & 1.137914 & 0.911820454 & -20.3144 & -5.34902 & -0.42024 & -0.11066 \\
\hline $\mathrm{Ga}$ & 14 & 14 & 1.014912 & 1.022328169 & -6.55169 & -2.80551 & -0.48291 & -0.20679 \\
\hline As & 0 & 6 & 0 & \#DIV/0! & -5.73934 & -5.73934 & -1 & -1 \\
\hline $\mathrm{Rb}$ & 5 & 19 & 0.274949 & 3.773696115 & -16.3352 & -14.9142 & -0.85992 & -0.78511 \\
\hline $\mathrm{Sr}$ & 149 & 144 & 1.031111 & 1.00626683 & -68.3975 & -27.9735 & -0.47466 & -0.19413 \\
\hline $\mathrm{Y}$ & 11.0 & 8.6 & 1.279496 & 0.810922887 & -2.98656 & 0 & -0.34811 & 0 \\
\hline $\mathrm{Zr}$ & 34 & 19 & 1.760016 & 0.589524592 & -2.00202 & 7.279369 & -0.10329 & 0.375554 \\
\hline $\mathrm{Nb}$ & 2.2 & 0.9 & 2.406773 & 0.431105339 & 0.207308 & 0.807342 & 0.22623 & 0.881032 \\
\hline Cs & 0.2 & 0.7 & 0.287767 & 3.605606903 & -0.56865 & -0.51648 & -0.85339 & -0.77509 \\
\hline $\mathrm{Ba}$ & 26 & 97 & 0.270864 & 3.830604627 & -83.7492 & -76.5894 & -0.862 & -0.7883 \\
\hline $\mathrm{La}$ & 2.0 & 1.5 & 1.295378 & 0.800980703 & -0.51586 & 0.018832 & -0.34002 & 0.012413 \\
\hline $\mathrm{Ce}$ & 4.7 & 3.0 & 1.548124 & 0.670213037 & -0.64421 & 0.640252 & -0.21124 & 0.209948 \\
\hline $\mathrm{Pr}$ & 0.77 & 0.49 & 1.58069 & 0.656405205 & -0.09448 & 0.114254 & -0.19465 & 0.2354 \\
\hline $\mathrm{Nd}$ & 4.2 & 2.6 & 1.599618 & 0.648637893 & -0.48344 & 0.65377 & -0.18501 & 0.250194 \\
\hline $\mathrm{Sm}$ & 1.37 & 0.88 & 1.562198 & 0.664174897 & -0.17867 & 0.193441 & -0.20407 & 0.220948 \\
\hline $\mathrm{Eu}$ & 0.56 & 0.43 & 1.284086 & 0.808024779 & -0.14947 & 0.00155 & -0.34577 & 0.003587 \\
\hline $\mathrm{Gd}$ & 1.65 & 1.23 & 1.340917 & 0.77377872 & -0.38984 & 0.059069 & -0.31681 & 0.048004 \\
\hline $\mathrm{Tb}$ & 0.31 & 0.23 & 1.364134 & 0.76060898 & -0.06917 & 0.015003 & -0.30499 & 0.06615 \\
\hline Dy & 1.98 & 1.49 & 1.327646 & 0.781513506 & -0.4819 & 0.056043 & -0.32358 & 0.037631 \\
\hline $\mathrm{Ho}$ & 0.40 & 0.30 & 1.318934 & 0.786675146 & -0.09922 & 0.009324 & -0.32801 & 0.030823 \\
\hline $\mathrm{Er}$ & 1.19 & 0.90 & 1.331249 & 0.779397845 & -0.28853 & 0.036273 & -0.32174 & 0.040448 \\
\hline Tm & 0.172 & 0.131 & 1.307493 & 0.793559098 & -0.0439 & 0.002877 & -0.33384 & 0.021881 \\
\hline $\mathrm{Yb}$ & 1.14 & 0.86 & 1.324856 & 0.783158844 & -0.28035 & 0.030581 & -0.325 & 0.035451 \\
\hline $\mathrm{Lu}$ & 0.166 & 0.122 & 1.363581 & 0.760917631 & -0.03716 & 0.008001 & -0.30527 & 0.065717 \\
\hline $\mathrm{Hf}$ & 1.0 & 0.5 & 1.769301 & 0.586430834 & -0.05326 & 0.206867 & -0.09856 & 0.382811 \\
\hline $\mathrm{Ta}$ & 0.1 & 0.0 & \#DIV/0! & 0 & 0.042825 & 0.065694 & \#DIV/0! & \#DIV/0! \\
\hline $\mathrm{Pb}$ & 3 & 3 & 1.05553 & 0.98298745 & -1.26075 & -0.47745 & -0.46222 & -0.17504 \\
\hline Th & 0.15 & 0.13 & 1.135329 & 0.91389602 & -0.05654 & -0.01511 & -0.42156 & -0.11267 \\
\hline $\mathrm{U}$ & 0.04 & 0.00 & \#DIV/0! & 0 & 0.018499 & 0.028378 & \#DIV/0! & \#DIV/0! \\
\hline \multirow[t]{2}{*}{$\mathrm{d}$} & 2.99 & 3.10 & 0.963788 & & & & & \\
\hline & & & $\mathrm{FV}=$ & & 0.528634 & 0.810923 & & \\
\hline
\end{tabular}


Tabela C5

\begin{tabular}{|c|c|c|c|c|c|c|c|c|}
\hline & Final & Inicial & & & Perdas - ganh & hos abs. & Relativos $(/ \mathrm{m0}$ & \\
\hline SAMPLE & miloníticos & isótropos & Final/Inicial & $F \vee$ para $x=0$ & Ti imóvel & Zr imóvel & Ti imóvel & Zr imóvel \\
\hline $\mathrm{SiO} 2$ & 49.80 & 49.39 & 1.008319 & 1.041166728 & -9.74084 & -18.6989 & -0.19723 & -0.37862 \\
\hline $\mathrm{Al} 2 \mathrm{O} 3$ & 12.99 & 14.75 & 0.880414 & 1.192425101 & -4.41184 & -6.74822 & -0.29906 & -0.45744 \\
\hline Fe2O3 & 13.32 & 10.91 & 1.220691 & 0.860027569 & -0.30714 & -2.70251 & -0.02816 & -0.24774 \\
\hline $\mathrm{MnO}$ & 0.156 & 0.175 & 0.888055 & 1.182165279 & -0.05133 & -0.07932 & -0.29298 & -0.45273 \\
\hline $\mathrm{MgO}$ & 6.44 & 7.66 & 0.840784 & 1.24863084 & -2.53158 & -3.68969 & -0.33062 & -0.48186 \\
\hline $\mathrm{CaO}$ & 7.42 & 11.00 & 0.674683 & 1.556030893 & -5.09175 & -6.42687 & -0.46286 & -0.58422 \\
\hline $\mathrm{Na} 2 \mathrm{O}$ & 2.60 & 1.93 & 1.349223 & 0.778098555 & 0.143155 & -0.32527 & 0.074174 & -0.16853 \\
\hline $\mathrm{K} 2 \mathrm{O}$ & 0.15 & 0.56 & 0.275703 & 3.807818824 & -0.43597 & -0.46367 & -0.7805 & -0.8301 \\
\hline TiO2 & 1.166 & 0.928 & 1.256057 & 0.835812873 & 0 & -0.20971 & 0 & -0.22595 \\
\hline P2O5 & 0.14 & 0.10 & 1.342466 & 0.782014966 & 0.007174 & -0.01801 & 0.068794 & -0.1727 \\
\hline LOI & 4.98 & 2.30 & 2.162333 & 0.485507181 & 1.661054 & 0.765577 & 0.721525 & 0.33255 \\
\hline TOTAL & 99.16 & 99.70 & 0.99457 & 1.055560531 & -20.7559 & -38.5935 & -0.20818 & -0.38709 \\
\hline $\mathrm{Sc}$ & 36.4 & 37.85714 & 0.961509 & 1.091854404 & -8.87756 & -15.4254 & -0.2345 & -0.40746 \\
\hline $\mathrm{V}$ & 247 & 243 & 1.017051 & 1.032227839 & -46.1568 & -90.536 & -0.19028 & -0.37324 \\
\hline $\mathrm{Cr}$ & 207 & 220 & 0.940615 & 1.116107883 & -55.3579 & -92.6557 & -0.25114 & -0.42034 \\
\hline Co & 38 & 34 & 1.106807 & 0.948519523 & -4.08031 & -10.9173 & -0.11882 & -0.31792 \\
\hline $\mathrm{Ni}$ & 114 & 117 & 0.977935 & 1.073515955 & -25.8157 & -46.3258 & -0.22142 & -0.39734 \\
\hline $\mathrm{Cu}$ & 71 & 62 & 1.138321 & 0.922260469 & -5.82769 & -18.5587 & -0.09373 & -0.2985 \\
\hline $\mathrm{Zn}$ & 76 & 58 & 1.310965 & 0.800805473 & 2.537537 & -11.1514 & 0.043715 & -0.19211 \\
\hline $\mathrm{Ga}$ & 17 & 17 & 1.010387 & 1.03903597 & -3.3138 & -6.39324 & -0.19559 & -0.37734 \\
\hline As & 0 & 3 & 0 & \#DIV/0! & -3.40398 & -3.40398 & -1 & -1 \\
\hline $\mathrm{Rb}$ & 7 & 21 & 0.340704 & 3.081346876 & -15.0241 & -16.2877 & -0.72875 & -0.79004 \\
\hline $\mathrm{Sr}$ & 182 & 238 & 0.765604 & 1.371241995 & -93.0456 & -125.864 & -0.39047 & -0.52819 \\
\hline $\mathrm{Y}$ & 22.6 & 18.6 & 1.213809 & 0.864904217 & -0.62669 & -4.6949 & -0.03364 & -0.25198 \\
\hline $\mathrm{Zr}$ & 126 & 77 & 1.622704 & 0.646962393 & 22.59321 & 0 & 0.291903 & 0 \\
\hline $\mathrm{Nb}$ & 6.8 & 6.2 & 1.111845 & 0.944221665 & -0.70652 & -1.93728 & -0.11481 & -0.31482 \\
\hline Cs & 1.1 & 0.6 & 1.817746 & 0.577544045 & 0.274042 & 0.073658 & 0.447185 & 0.120196 \\
\hline $\mathrm{Ba}$ & 41 & 156 & 0.260335 & 4.032604974 & -123.902 & -131.221 & -0.79274 & -0.83957 \\
\hline $\mathrm{La}$ & 7.7 & 8.1 & 0.946235 & 1.109479525 & -2.00839 & -3.39432 & -0.24666 & -0.41688 \\
\hline $\mathrm{Ce}$ & 19.7 & 17.8 & 1.104123 & 0.95082561 & -2.15465 & -5.69257 & -0.12096 & -0.31958 \\
\hline $\operatorname{Pr}$ & 2.85 & 2.28 & 1.24655 & 0.842186753 & -0.01728 & -0.52923 & -0.00757 & -0.23181 \\
\hline $\mathrm{Nd}$ & 14.2 & 10.4 & 1.360768 & 0.771496825 & 0.867254 & -1.67925 & 0.083365 & -0.16142 \\
\hline Sm & 3.93 & 2.60 & 1.509339 & 0.6955548 & 0.525121 & -0.18193 & 0.201649 & -0.06986 \\
\hline $\mathrm{Eu}$ & 1.36 & 0.97 & 1.395787 & 0.752140666 & 0.108087 & -0.13587 & 0.111245 & -0.13984 \\
\hline $\mathrm{Gd}$ & 3.99 & 2.83 & 1.408415 & 0.745397089 & 0.343484 & -0.37395 & 0.121299 & -0.13206 \\
\hline $\mathrm{Tb}$ & 0.70 & 0.51 & 1.377284 & 0.762245486 & 0.049208 & -0.07711 & 0.096514 & -0.15124 \\
\hline Dy & 4.26 & 3.21 & 1.330021 & 0.789332368 & 0.188758 & -0.57817 & 0.058886 & -0.18037 \\
\hline $\mathrm{Ho}$ & 0.85 & 0.64 & 1.329587 & 0.789589824 & 0.037525 & -0.11579 & 0.058541 & -0.18063 \\
\hline $\mathrm{Er}$ & 2.57 & 1.92 & 1.336935 & 0.785249819 & 0.123602 & -0.33804 & 0.064391 & -0.17611 \\
\hline $\mathrm{Tm}$ & 0.393 & 0.286 & 1.375104 & 0.763453855 & 0.027096 & -0.04362 & 0.094779 & -0.15258 \\
\hline $\mathrm{Yb}$ & 2.57 & 1.83 & 1.407794 & 0.745725582 & 0.2209 & -0.24217 & 0.120805 & -0.13244 \\
\hline Lu & 0.387 & 0.260 & 1.490369 & 0.704408402 & 0.04849 & -0.0212 & 0.186546 & -0.08155 \\
\hline $\mathrm{Hf}$ & 3.3 & 2.0 & 1.655528 & 0.634134926 & 0.639764 & 0.040691 & 0.318036 & 0.020228 \\
\hline $\mathrm{Ta}$ & 0.5 & 0.4 & 1.067659 & 0.983299188 & -0.06606 & -0.15064 & -0.14999 & -0.34205 \\
\hline $\mathrm{Pb}$ & 3 & 4 & 0.842775 & 1.245680661 & -1.34364 & -1.96273 & -0.32903 & -0.48064 \\
\hline $\mathrm{Th}$ & 0.96 & 1.60 & 0.60288 & 1.741354705 & -0.83175 & -1.00521 & -0.52002 & -0.62847 \\
\hline $\mathrm{U}$ & 0.27 & 0.31 & 0.869821 & 1.206948182 & -0.0939 & -0.14167 & -0.3075 & -0.46397 \\
\hline \multirow[t]{2}{*}{$\mathrm{d}$} & 2.88 & 3.03 & 0.952537 & & & & & \\
\hline & & & $\mathrm{FV}=$ & & 0.835813 & 0.646962 & & \\
\hline
\end{tabular}



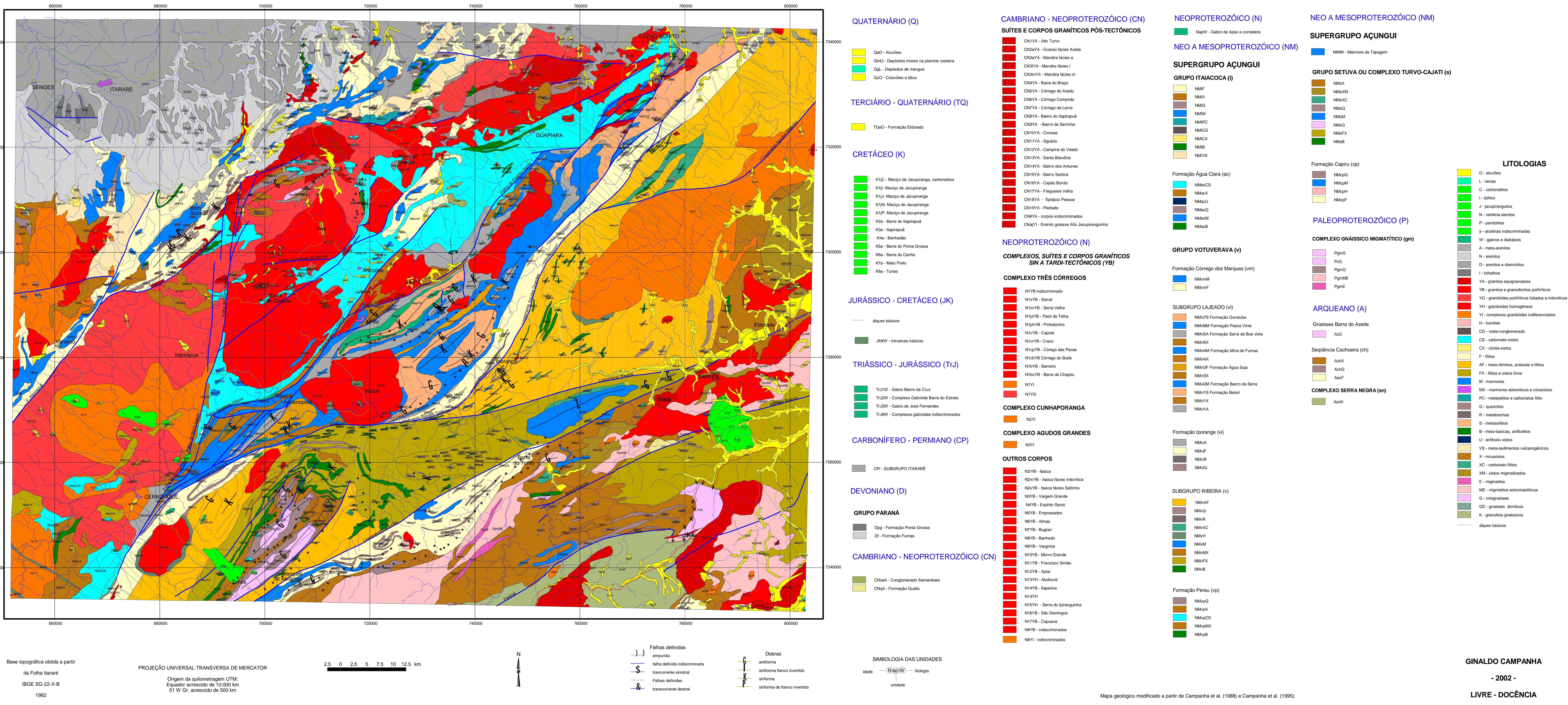

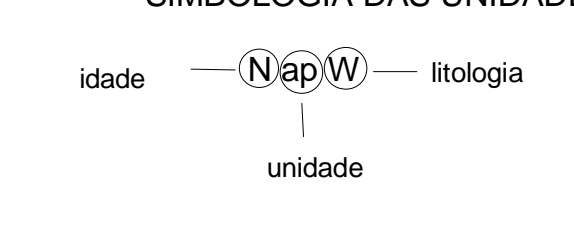




\section{DADOS DA TESE DE LIVRE DOCÊNCIA}

Favor preencher corretamente com os dados (todos os campos são obrigatórios):

Nome completo: Ginaldo Ademar da Cruz Campanha

No. USP: 915463 E-mail: ginaldo@usp.br

Área de Conhecimento CNPq (Lattes): geologia

Data de defesa (indicar o primeiro dia do processo de defesa): 10/02/2003

Digite o título no idioma original

O papel do sistema de zonas de cisalhamento transcorrentes na configuração da porção meridional da Faixa

Ribeira

Digite as palavras-chave no idioma original

zonas de cisalhamento, Cinturão Ribeira, falhas transcorrentes, análise da deformação, Gondwana

Selecione o idioma alternativo: Inglês

Digite o título em Inglês

The role of the wrench shear zones in the configuration of the Southern portion of the Ribeira Belt

Digite as palavras-chave em Inglês

shear zones, Ribeira Belt, wrench faults, strain analysis, Gondwana

Forma de disponibilização da tese/dissertação:

Pública: todos os arquivos serão acessíveis na Internet.

Restrita: todos os arquivos serão acessíveis somente na USP.

Retida: todos os arquivos não serão acessíveis.

Mista: combinação das três formas de disponibilização individualmente para cada arquivo. Neste caso, indicar quais arquivos serão públicos, restritos ou retidos (relacionar no verso os arquivos e suas disponibilidades).

Especialidade da tese: tectônica, geologia estrutural, geologia regional

\section{Membros da banca:}

Nome completo Instituição

Benjamim Bley de Brito Neves

Georg Robert Sadowski

Alberto Pio Fiori

Peter Christian Hackespacher

Mônica Heilbron

\begin{tabular}{|l|}
\hline USP \\
\hline USP \\
\hline UFPr \\
\hline UNESP \\
\hline UERJ
\end{tabular}

